\title{
Emsian (Lower Devonian) conodont stratigraphy and correlation of the Anti-Atlas (Southern Morocco)
}

\author{
Zhor SARAH Aboussalam, Ralph ThOMAs BeCKER \& PierRe BULtynck
}

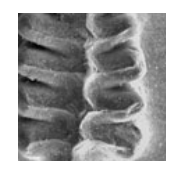

\begin{abstract}
Based on revised previous records and many new data from the Tafilalt, Maider, eastern and western Dra Valley, the Emsian litho- and conodont biostratigraphy of the Anti-Atlas is reviewed, with some data on the Pragian below and the basal Eifelian above. More than 14.000 platform and single cone elements are assigned to 62 species/subspecies of 16 genera, partly in open nomenclature. The region is characterized by rather episodic polygnathid occurrences despite a predominant outer shelf biofacies with abundant dacryoconarids and goniatites. The studied Tafilalt polygnathid succession is as follows: rare records of Eoctenopolygnathus pireneae (Pragian), Eolinguipolygnathus excavatus Morphotype 114 Zone (basal Emsian, with Eol. radula sp. nov.), Eol. catharinae Subzone (of Eol. gronbergi Zone), Linguipolygnathus inversus Zone (with dominant Eol.jacksoni), Eol. laticostatus Zone (at the top of the lower Emsian), a regional basal upper Emsian interregnum (locally with the last L. inversus), L. bultyncki Zone (with L. cooperi cooperi Subzone), Polygnathus patulus Zone, Po. partitus Zone (basal Eifelian). Abundant icriodids provide an alternative zonation, from base to top with Latericriodus steinachensis Zone (lower/middle Pragian), Caudicriodus celtibericus Zone (upper Pragian/basal Emsian), Lat. bilatericrescens gracilis Zone, Lat. bilatericrescens bilatericrescens Zone, Lat. latus Zone, Icriodus fusiformis Zone (basal upper Emsian, with Icriodus ovalis sp. nov. and I. praerectirostratus sp. nov.), and I. corniger corniger Zone. Criteriognathus miae and Crit. steinhornensis provide an alternative ozarkodinid zonation in the Pragian to lower Emsian. The conodont sequences are correlated with the regional ammonoid zonations and global event succession. It contributes to the current chronostratigraphic revision of the Emsian. The Zinzilban basal Emsian GSSP level may project into the lower "Pragian Limestone" of the Tafilalt. The proposed revised basal Emsian GSSP level at the first appearance of Eol. excavatus Morphotype 114 is correlated in the Tafilalt with the base of the Devonobactrites Shale. A significant change of conodont faunas and facies took place at the top of the Mimagoniatites Limestone (main Daleje Event). The significant icriodid radiation of the I. fusiformis Zone is relevant for the debate on Emsian substage subdivision. Lenzites gesinae Klug, 2001 is designated as the type species of the new goniatite genus Klugites. - Key words: Emsian, conodonts, ammonoids, lithostratigraphy, biostratigraphy, chronostratigraphy, global events, Morocco.
\end{abstract}

\begin{abstract}
ABOUSSALAM, Z.S., BECKER, R.T. \& BULTYNCK, P. 2015. Emsian (Lower Devonian) conodont stratigraphy and correlation of the Anti-Atlas (Southern Morocco). Bulletin of Geosciences 90(4), 893-980 (32 figures, 5 tables). Czech Geological Survey, Prague. ISSN 1214-1119. Manuscript received September 3, 2014; accepted in revised form July 7 , 2015; published online November 27, 2015; issued November 30, 2015.

Zhor Sarah Aboussalam, Institut für Geologie und Paläontologie, Westfälische Wilhelms-Universität Münster, Corrensstr. 24, D-48149 Münster, Germany; taghanic@uni-muenster.de・Ralph Thomas Becker (corresponding author), Institut für Geologie und Paläontologie, Westfälische Wilhelms-Universität Münster, Corrensstr. 24, D-48149 Münster, Germany; rbecker@uni-muenster.de•Pierre Bultynck, Départment de Paléontologie, Institut royal des Sciences naturelles de Belgique, rue Vautier 29, B-1000 Bruxelles, Belgium; pierre.bultynck@belgacom.net
\end{abstract}

Recent geochronological scales suggest that the Emsian was a long to very long time interval, with estimated durations that vary widely between 9.5 (Gradstein et al. 2004) and 17.2 Ma (Kaufmann 2006). The most recent revision (Becker et al. 2012) assumes a time length of ca $14.3 \mathrm{Ma}$, exceding the Famennian (at ca 13.3 Ma). Therefore, the International Subcommission on Devonian Stratigraphy (SDS) has decided to subdivide the stage into two substages (Becker 1997, 2003), at a level close to the Zlíchovian/Dalejan transition or Daleje Event of Bohemia (e.g.,
Chlupáč 1995, Jansen \& Schindler 1997, Walliser 1997, Chlupáč \& Lukeš 1999, Bultynck et al. 2000, Becker 2007). The base of the Emsian was defined in the Zinzilban section of the Kitab Reserve, Uzbekistan (Yolkin et al. 1998). However, this decision has been questioned (e.g., Walliser 1997, Chlupáč \& Lukeš 1999) since the chosen GSSP level places more than half of the classical Pragian of Bohemia into the lower Emsian. This was confirmed in subsequent reviews by Carls \& Valenzuela-Ríos (2007), Carls et al. (2008, 2009), and Jansen (2012). Therefore, 
SDS decided during its Annual Meeting 2007 in the Kitab Reserve to formally revise the base of the Emsian (Becker 2009). It was decided to search within the Kitab region for a new and higher GSSP level near the entry of Eolinguipolygnathus excavatus Carls \& Gandl, 1969 (see Kalvoda 1995 ) or of its advanced "ssp. 114" sensu Carls \& Valenzuela-Ríos (2002). The first entry of Eocostapolygnathus kitabicus Yolkin, Weddige, Izokh \& Erina, 1994, the current basal Emsian index conodont, shall define in future a formal Upper Pragian ("Zinzilbanian") substage.

Although the current Emsian revision focuses on the Kitab region (Yolkin et al. 2011; Izokh et al. 2011a, b; Kim et al. 2012), it is clear that a new basal Emsian GSSP must have the potential for wide international correlation. The same applies to the future intra-Emsian substage boundary, which will not necessarily be defined in Bohemia. This requires the detailed documentation of sedimentary and faunal successions from as many other regions as possible (e.g., Martínez-Pérez et al. 2011; Lu 2013; Martínez-Pérez \& Valenzuela-Ríos 2012, 2014; Baranov et al. 2014). The correlation between the stratigraphically most important fossil groups of the time, especially between conodonts, ammonoids and dacryoconarids, needs to be improved. New brachiopod and palynomorph data are required to facilitate a better correlation from the pelagic facies realm into the neritic and terrestrial settings (e.g., Jansen 2012).

The Anti-Atlas of southern Morocco represents on a global scale one of the most fossiliferous Emsian regions. Building on literature data, the revision of old faunas and new samples (preliminary data in Bultynck \& Walliser 2000a, Becker \& Aboussalam 2011, Dojen et al. 2011, Becker et al. 2013b, Aboussalam \& Becker 2013), this contribution documents the Emsian litho- and conodont stratigraphy of the Tafilalt/Maider and Dra Valley regions, and discusses implications for chronostratigraphy and the correlation between fossil groups. More than 14.000 platform and single cone elements belong to 16 genera and 62 species/subspecies, including three new taxa, and not counting some Eifelian specimens and species.

Abbreviations. - Conodonts: Bel.$=$ Belodella, Caud.$=$ Caudicriodus, Crit.$=$ Criteriognathus, Eoc.$=$ Eocostapolygnathus, Eoct. = Eoctenopolygnathus, Eol. $=$ Eolinguipolygnathus, I. = Icriodus, L. = Linguipolygnathus, Lat. $=$ Latericriodus, Neop. = Neopanderodus, Oz. = "Ozarkodina", P. = Panderodus, Pel. $=$ Pelekysgnathus, Po. $=$ Polygnathus, Pseud. = Pseudooneotodus.

Ammonoids/goniatites: An. = Anarcestes, Anet. $=$ Anetoceras, Erb. = Erbenoceras, Lat. = "Latanarcestes" auct., Sell. $=$ Sellanarcestes.

Figured conodonts collected by ZSA and RTB are housed under the collection number B9.A-5 in the type col- lection of the Geomuseum of the WWU Münster. Condonts of PB are kept in the micropalaeontology collection of the Muséum des Sciences Naturelles, Brussels, under the numbers b6591 to b6690.

\section{Emsian lithostratigraphy of the Anti-Atlas (Fig. 1)}

\section{Informal lithostratigraphy of the Tafilalt}

Despite its superb outcrops and international significance, the lithostratigraphy of the Tafilalt is still in an incipient stage. Hollard (1960, 1963a, 1967) subdivided its Devonian succession into lithological units with characteristic faunas but did not suggest formation names. This principle was kept on the explanation of the geological map (sheet Tafilalt-Taouz, Destombes \& Hollard 1986). A correlation chart by Hollard (1981b) introduced group names but without explanations and without formally named formations. This system was summarized and updated by Bultynck \& Walliser 2000a, b). The Emsian falls in the upper part of the Seheb el Rhassel Group and Amerboh Group. Kröger (2008) improved the distinction of Lower Devonian marker units with nautiloids in the southern Tafilalt. His data, the recognition of two important hypoxic shales below the widespread Anetoceras Limestone (Belka et al. 1999, Becker \& House 2000, Klug 2001, Klug et al. 2008), and the preliminary results of Becker \& Aboussalam (2011) and Aboussalam \& Becker (2013) provide a more refined informal Emsian litho- and event stratigraphy of the Tafilalt. Becker et al. (2013a) assigned all of the Tafilalt Devonian to lithological units numbered from A to Y, with Units E to $\mathrm{L}$ covering the upper Pragian to basal Eifelian interval. Since a revised smaller-scale (than previously) geological mapping is currently in progress in the region, we cannot establish new formal lithostratigtraphic terms.

Unit E, (regional) "Pragian Limestone" (Bultynck \& Walliser 2000a). - ["Calcaires marneux noduleux jaunâtres à trilobites" in Hollard 1963a; Units a1-2 in Hollard 1967; Unit c in Alberti 1980, 1981; Pragian Limestone (Unit B2) in Bultynck \& Walliser 2000a, b; De Baets et al. 2010; Becker \& Aboussalam 2011; Becker et al. 2013b.]

This unit of light-grey marly and nodular limestone may reach more than $10 \mathrm{~m}$ of thickness and is best characterized by its diverse and locally very rich trilobite fauna. Most characteristic are phacopids (Reedops, Boeckops), cheirurids (Crotalocephalina), scutelluids (Paralejurus), dalmanitids (Odontochile), and harpids. Orthoconic cephalopods are very common in specific levels (Kröger 2008, Klug et al. 2013). Some sections contain thin limestones within the underlying "Pragian Marls and Shales" (Unit D). With respect to the currently unstable position of 
the formal Pragian/Emsian boundary and a different meaning of the term in the Bohemian type region, this unit should be re-named in a future formal lithostratigraphic subdivision.

Unit F, Devonobactrites Shale (Becker \& Aboussalam 2011). - [Shale with Asteropyginae above Unit c in Alberti 1980, 1981; "Niveau ferrugineux" in Hollard 1981b; unit B3 in Bultynck \& Walliser 2000a, b; lower haematitic fauna in Becker \& House 2000; shale with Faunule 1 in Klug et al. 2008.]

This hypoxic shale with locally abundant goethitic fauna, especially from Bou Tchrafine to Ouidane Chebbi and in the Amessoui Syncline, is characterized by the sudden entry of abundant earliest bactritids (Devonobactrites), acanthodian spines (Machaeracanthus), and small asteropygids (Metacanthina, Pilletina). They are accompanied by fossil groups that are normally rather rare in cephalopod shales, such as hyolithids, edrioasteroids, phyllocarids (Ceratiocaris, Nahecaris), and machaeridians (Lepidocoleus). The complete fauna has been documented in Klug et al. (2008) and De Baets et al. (2010).

Unit G, Deiroceras Limestone (Kröger 2008). - [Lower part of Fauna di 3.1 with Jovellania in Hollard 1974; "calcaires bleu noir à nautiloides" in Bultynck \& Hollard 1980 and Hollard 1981b; calcaires à "Jovellania" in Destombes \& Hollard 1986; "Jovellania" Limestone (Unit C1) in Bultynck \& Hollard 2000a, b; Unit A in Klug 2001.]

Kröger (2008) emphasized that the nautiloid Jovellania does not occur in this limestone unit that has been informally named after it; instead the large-sized genus Deiroceras is characteristic and provided the corrected name. Other macrofauna is rare. Since a true Jovellania Limestone succession occurs below in the upper Lochkovian, it is not possible to continue the same name for an Emsian unit.

Unit H, Metabactrites-Erbenoceras Shale (Becker \& Aboussalam 2011). - [Middle, marly part of Fauna di 3.1 with Machaeracanthus in Hollard 1974; "Argillites grises" in Bultynck \& Hollard 1980; "marno-calcaires à Machaeracanthus" in Destombes \& Hollard 1986; Unit C2 in Bultynck \& Walliser 2000a, b; Unit B in Klug 2001; shale with Faunule 2 in Klug et al. 2008.]

This second lower Emsian hypoxic shale interval (Becker \& House 2000) is characterized by the sudden incoming of a diverse early ammonoid fauna, notably with Metabactrites, Erbenoceras, Chebbites, and Gyroceratites. Machaeracanthus, hyolithids, various gastropods and bivalves of Faunule 1 re-appear, but not the edrioasteroids, machaeridians, and phyllocarids. The complete assemblage has been described in Klug et al. (2008) and De Baets et al. (2010).
Unit I, Anetoceras Limestone (adopted from Hollard 1963 a in Bultynck \& Walliser 2000a). - [Lower part of "calcaires à Mimagoniatites et Anetoceras advolvens" in Hollard 1963a; Unit a4 in Hollard 1967; upper part of Fauna di 3.1 with Anetoceras (Erbenoceras) advolvens Erben, 1960 in Hollard 1974; "calcaires roses à Tentaculites" and "Calcaires gris et marnes" in Bultynck \& Hollard 1980, and Hollard 1981b; lower to middle part of Unit d in Alberti 1980, 1981; "niveau supérieur à Anetoceras advolvens" in Destombes \& Hollard 1986; Erbenoceras Beds in Belka et al. 1999; Anetoceras Limestone (lower part of Unit C3) in Bultynck \& Walliser 2000a, b (compare Becker \& House 2000 and Becker \& Aboussalam 2011); Units C, D in Klug 2001; lower to middle part of the Erbenoceras Limestone of Kröger 2008 and Klug et al. 2013; lower to middle part of the Erbenoceras Beds of De Baets et al. 2010.]

Although Erbenoceras (= Kokenia ex gr. obliquecostata in Massa, 1965) is the most common ammonoid in this unit, especially in its lower part, it is the entry of Anetoceras s. str., which distinguishes its faunas from the underlying shales. Both genera can be clearly recognized despite significant morphological variability (De Baets et al. 2013). Well above the base, Klugites gen. nov. is locally common. Relatives of Erb. solitarium Barrande, 1865, Teicherticeras and Weyerites are other, rare marker goniatites.

Unit J, Mimagoniatites Limestone (adopted from Hollard 1963a in Walliser 1991). - [Top part of Fauna di 3.1 in Hollard 1974; upper part of "Calcaires à Mimagoniatites et Anetoceras advolvens" in Hollard 1963a; Unit a5 in Hollard 1967; "Calcaires bleu gris foncé" in Bultynck \& Hollard 1980; upper part of Unit d in Alberti 1980, 1981; Mimagoniatites Limestone in Walliser 1991 (compare Becker \& Aboussalam 2011); "blue Mimagoniatites Limestone" in Bultynck \& Walliser 2000a, b; Unit E in Klug 2001; upper part of Erbenoceras Limestone in Kröger 2008 and Klug et al. 2013; upper part of Erbenoceras Beds in De Baets et al. 2010.]

Separated from the Anetoceras Limestone by some marl or more argillaceous limestone, the medium to dark bluish-grey Mimagoniatites Limestone forms a distinctive lithological marker in the upper part of the "Anetoceras Ridge" (Becker \& House 2000) and at the top of the lower Emsian. The last limestone beds tend to be more nodular and light grey. Mimagoniatites is the only common ammonoid, but associated there are many, often large, nautiloids (e.g., Metarmenoceras, see Kröger 2008), large bivalves (Panenka), and placoderm remains.

Unit K, Daleje Shale Equivalents (Becker \& House 2000). - ["Schistes gris ou marnes" and "Marno-calcaires à goniatites pyriteuses" in Hollard 1963a; Unit b6 in Hollard 1967; Unit e in Alberti 1980, 1981; lower and middle 
formations of Amerboh Group in Hollard 1981b; Unit di ${ }_{3-4}$ in Destombes \& Hollard 1986; Latanarcestes Shale in Bultynck \& Walliser 2000a, b; "Late Emsian marls" in Klug 2002.]

In basinal settings this distinctive shale-siltstone interval is more than 100 m thick. Becker \& House (2000) and Klug (2002) correlated its base with the Daleje Event of Bohemia (= Mid-Emsian Event in Bultynck \& Walliser 2000a, b). In the lower part faunas with Gyroceratites and mimagoniatitids are very characteristic (Alberti 1980; Becker \& House 1994, 2000). New collections show that the latter belong to Rherisites Klug, 2002. In the ca upper half first anarcestids enter, including forms that have commonly been assigned to Latanarcestes (Hollard et al. 1967, Becker \& House 1994, Klug 2002). The type of this genus, however, is most likely from the Eifelian and the basal upper Emsian group needs to be re-named. Consequently, the name Latanarcestes Shale (Bultynck \& Walliser 2000a) is not appropriate. Klug (2002) showed that the first Sellanarcestes (Sell. eos Klug, 2002) also appear in the thick shale unit, probably in its upper part (Becker in Webster et al. 2005). This means that the Daleje Shale Equivalents of the Tafilalt includes some younger strata than the type Daleje Shale of Bohemia. Therefore, a new, neutral term should be established in a future formal lithostratigraphic scheme for the Tafilalt.

Unit L, Anarcestes Limestone (adopted from Hollard 1963a). - ["Calcaires et marno-calcaires à polypiers, trilobites et Anarcestes lateseptatus" in Hollard 1963a, "schistes argileux gris et calcaires argileux" (Units b7-9) in Hollard 1967; upper formation of Amerboh Group in Hollard 1981b; "calcaire argileux à Favosites, Anarcestes lateseptatus" $\left(\mathrm{dm}_{1-1}\right)$ in Destombes \& Hollard, 1986; Unit D in Walliser 1991; Sellanarcestes Limestone/Marl in Bultynck \& Walliser 2000a, b and Lubeseder et al. 2010; "Late Emsian nodular limestones" in Klug 2002.]

The main goniatite genus that ranges from the very base of this unit (Becker in Webster et al. 2005) to the top (Klug 2002, section Gara Mdouara) is Anarcestes. Therefore, it is best to name the unit after this marker genus. Sellanarcestes is restricted to its lower part (Becker \& House 1994). Achguigites and Sell. neglectus (Barrande, 1865) enter slightly above the base in Sellanarcestes-Anarcestes assemblages. The extinction of Sellanarcestes defines a middle part (Becker \& House 1994, Klug 2002) of the Anarcestes Limestone. The upper part is rather unfossiliferous, with An. lateseptatus (Beyrich, 1837) as the main index species. This subdivision was already known to Hollard (1967), who distinguished a level with Sellanarcestes (b7) and two levels with Anarcestes (b8-9). The change from pelagic and hypoxic ammonoid shales of the Daleje Shale equivalents to condensed, hemipelagic cephalopod limestone suggests a shallowing at the base of the Anarcestes Limestone. This contradicts the interpretation of Lubeseder et al. (2010), who interpreted his corresponding Sellanarcestes Limestone as a transgressive unit. The Emsian-Eifelian boundary lies within the top part of Unit L (Bultynck \& Walliser 2000a).

\section{Formal formation terminology of the Maider (Fig. 1)}

Hollard (1974) subdivided the upper Emsian to Frasnian of the Maider (and southern Tafilalt) into a succession of numbered ammonoid zones and named formations. He included his Faunas di 3 and di 4, the interval from the Deiroceras Limestone to the nodular limestones with Sell. wenkenbachi (Kayser, 1884), in a "Formation du Talus d'Issemour". The upper Emsian Fauna with "Anarcestes" neglectus was thought to represent the basal Middle Devonian and called Fauna dm 1.1. Within his El Otfal Formation it was aligned with a poorly fossiliferous interval (Fauna $\mathrm{dm}$ 1.2) and with the top Emsian/lower Eifelian Fauna dm 1.3. Hollard (1981b) altered this scheme and distinguished in the Emsian of the Maider at the base an Ihandar Formation, then a Bou Tiskaouine Formation (correlating with the Deiroceras to Mimagoniatites Limestones, Units G-J), an Er Remlia Formation (correlating with the Tafilalt Unit $\mathrm{K}$ ), and subsequent Tazoulait and El Otfal formations. The basal upper Emsian Er Remlia Formation includes many argillaceous limestones or even limestone cliffs in comparison with the contemporaneous Daleje Shale Equivalents of the Tafilalt. The higher upper Emsian Tazoulait Formation correlates with the Sellanarcestes-rich, more condensed lower Anarcestes Limestone of the Tafilalt. Solid limestones serve as a lithostratigraphical marker at the top. The Lower Member of the El Otfal Formation straddles the Emsian/Eifelian boundary. It is unfortunate that the subsequent sequence stratigraphic approach of Döring (2002) made no attempt to use or correlate Hollard's terminology. However, Döring used the goniatite limestones of the Bou Tiskaouine Formation, the argillaceous interval of the Er Remlia Formation (Daleje Shale Equivalent), the Sellanarcestes-rich limestones of the Tazoulait Formation, and the subsequent more nodular limestones to recognize regional Depophases $\mathrm{Oa}, \mathrm{Ob}, 1 \mathrm{a}, 1 \mathrm{~b}$, and 2.

Figure 1. Comparison of the Emsian lithostratigraphy of the Tafilalt, Maider, eastern and western Dra Valley regions and the position of recognized global events. Numbers E to L refer to the Tafilalt lithological units of Becker et al. (2013a). 


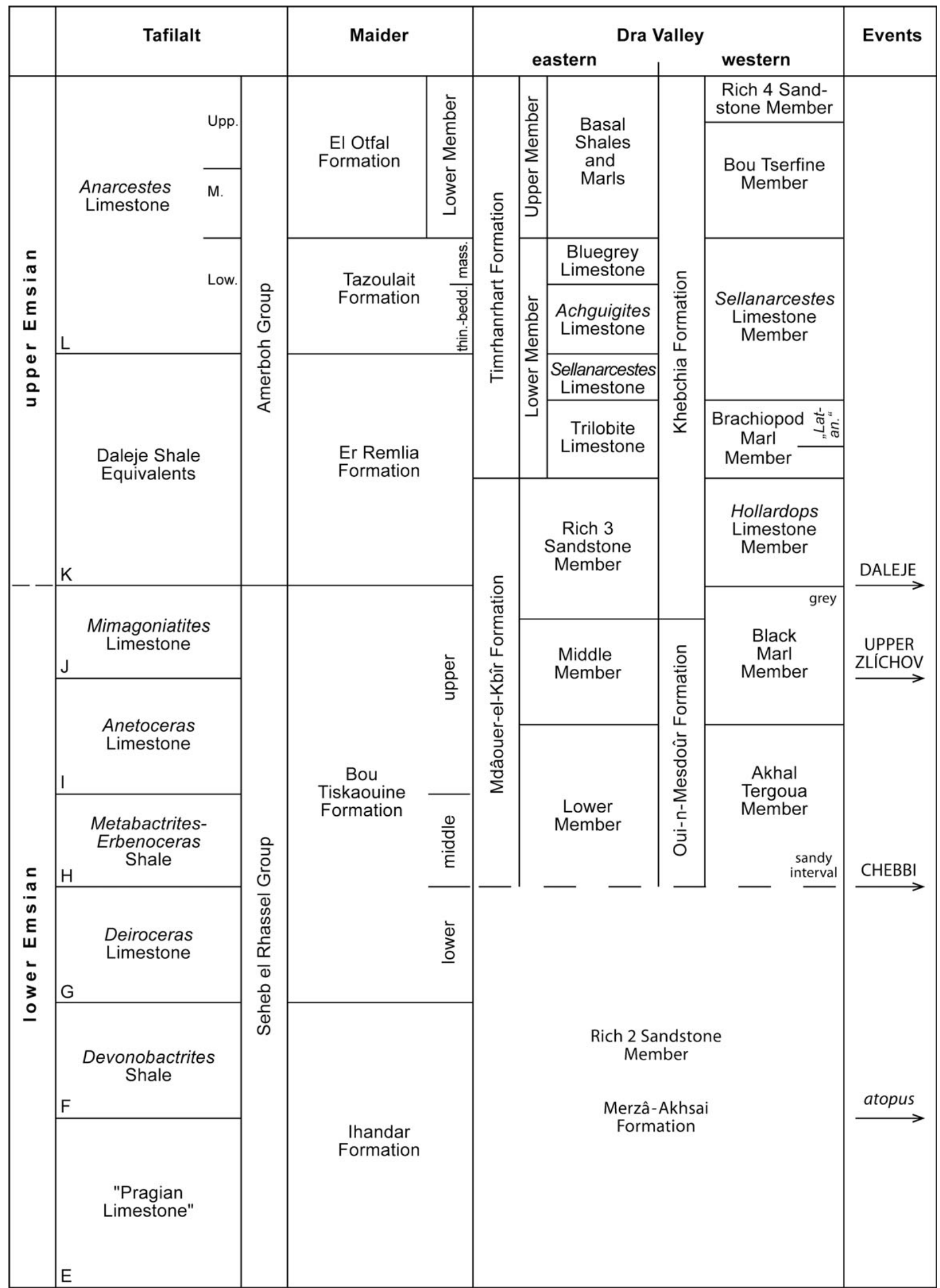




\section{Emsian lithostratigraphy of the Dra Valley (Fig. 1)}

The litho- and biostratigraphy of the Dra Valley Devonian has been summarized by Becker et al. (2004a) and Jansen et al. (2007). Subsequently, Ouanaimi \& Lazreq (2008) and Lubeseder et al. (2009) investigated the sedimentology, sequence stratigraphy and synsedimentary tectonics of the Lower Devonian of the region. The formation terminology was introduced by Hollard (1978), replacing informal names used in Hollard (1967). The concept of cyclic sedimentation within the regional Rich Group was further outlined by Hollard (1981a). The eastern (ca Foum Zguid to Tata) and western Dra Valley ( $c a$ Akka to Ain-n'Delouine $=$ Ain Deliouine) regions display different Emsian successions (e.g., Hollard 1967, 1978; Bultynck \& Hollard 1980).

In all of the Dra Valley the base of the Emsian (of any definition) lies within the Rich 2 Sandstone Member of the upper Merzâ-Akhsai Formation, which contains no conodonts. In the eastern succession the following Mdâouer-el-Kbîr Formation can be subdivided into three members, a Lower Member with limestones, marls, Erbenoceras and other goniatites (details in De Baets et al. 2010), a fine siliciclastic Middle Member ("Grès d'El Mdâouer Srhir" in Hollard 1978), and the (upper) Rich 3 Sandstone Member ("Grès et lumachelles du Mdâouer-el-Kbîr" in Hollard 1978) with some sandy limestones in its upper part. The subsequent Timrhanrhart Formation consists of two members. The Lower Member clearly falls in the upper Emsian. In ascending order, it consists at Oufrane of a Trilobite Limestone at the base, a massive Sellanarcestes Limestone (without Anarcestes), the nodular Achguigites Limestone (with Anarcestes), and a Bluegrey Limestone dominated by Anarcestes faunas (Ebbighausen et al. 2011). The Emsian-Eifelian boundary lies in overlying shales and marls of the Upper Member (compare Jansen et al. 2004a).

In the western succession, the Merzâ-Akhsai Formation is overlain by the Oui-n-Mesdoûr Formation, which consists of dark limestones in the lower part (Akhal Tergoua Member), partly with large trilobites (Odontochile), and an upper Black Marl Member with rare Erbenoceras (Becker et al. 2008) and very restricted benthos. The subsequent Khebchia Formation begins with the trilobite-rich Hollardops Limestone Member (details in Brett et al. 2012), followed by the Brachiopod Marl Member, with a "Latanarcestes" level in its upper half, the Sellanarcestes Limestone Member (with frequent Anarcestes, Becker et al. 2004c), and by a thick package of shale and siltstones, the Bou Tserfine Member. The Emsian-Eifelian boundary lies within the rather unfossiliferous Rich 4 Sandstone Member at the top of the formation.

\section{Previous work on Emsian conodonts from the Anti-Atlas}

The first Emsian conodont data from the Tafilalt were provided by Massa (1965), based on identifications by M. Lys and M. Mauvier (see repetition in Hollard 1974). The faunal lists include first regional records of species, such as Lat. bilatericrescens (Ziegler 1956), Crit. steinhornensis (Ziegler, 1956), and Pseud. beckmanni (Bischoff \& Sannemann, 1958). Other forms, however, especially the polygnathids, were given post-Emsian species names. Due to the lack of illustrations, these identifications cannot be revised without re-examination of the material. The more detailed conodont biostratigraphy of the region begun with Bultynck \& Hollard (1980, 1982), who introduced a succession of numbered regional faunas, based on different successions either from the Tafilalt (sections Bou Tchrafine West, Bou Tchrafine North, Hamar Laghdad, Fig. 2), SW Maider (Ou Driss), or from numerous localities of the eastern and western Dra Valley. Their regional zonation, which is revised here, can be summarized as follows:

Fauna VIII - Po. costatus patulus - Maider - [now Po. patulus]

Fauna VII - Po. serotinus - Maider - [now L. serotinus]

Fauna VIc - Po. linguiformis cooperi - Tafilalt - [now L. cooperi cooperi]

Fauna VIb - Po. linguiformis $\alpha$ - Maider, eastern and western Dra Valley - [now L. bultyncki]

Fauna VIa - I. rectirostratus - eastern and western Dra Valley - I. corniger

Fauna $\mathrm{Vb}$ - I. fusiformis - western Dra Valley

Fauna Va - Po. laticostatus - Tafilalt - [now Eol. laticostatus]

Fauna IV - Oz. steinhornensis steinhornensis - Tafilalt - [now Crit. steinhornensis]

Fauna III - Po. gronbergi - Tafilalt - [now Eol. gronbergi]

Fauna II - Lat. bilatericrescens - Maider, eastern and western Dra Valley

Fauna Ib - Oz. steinhornensis miae - Tafilalt - [now Crit. miae]

Fauna Ia - Po. dehiscens - Tafilalt - [now Eol. excavatus] - Caud. sigmoidalis

The succession combines intervals defined by representatives of three different conodont groups, which have a partly different biofacies distribution: polygnathids, icriodids, and spathognathodids ("ozarkodinids"). It is possible to separate regional zonations for the three groups and to correlate them internationally. Their vertical combination reflects distinctive palaeoecological trends of the region, further complicated by intervals (ecozones) dominated in certain sections or in the whole region by 
long-ranging, supposed shallow-water single cone genera, such as Belodella (compare first data of Massa 1965), Coelocerodontus, Panderodus, or Neopanderodus.

Bultynck (1985) added new data for the Ou Driss section (SW Maider), with further evidence for Faunas Ia, Ib, IV, Va, VIa/b, VIc, VII, and VIII. In the northern Maider, at the Jebel Issimour (section Tizi n'Ikouâch) and in the Ouihlane (= Ouahlane) Syncline, Faunas VIa to VIII were recognized. Based on the comparison with Bohemia (Klapper et al. 1978), he considered that the appearance of L. bultyncki indicates the base of the serotinus Zone. Emsian conodont data for Ou Driss were also briefly discussed in Bultynck (1991). Belka et al. (1999) provided some new data for the lower Emsian of the Ouidane Chebbi at the eastern margin of the Tafilalt, with very few conodonts from the upper Emsian. Subsequently, Z. Belka identified in Klug et al. (2000) and Klug (2002) a few samples from the Anarcestes Limestone of the Jebel Ouaoufilal (Amessoui Syncline, southern Tafilalt). In a more general review of the Tafilalt, Bultynck \& Walliser (2000a) included updated lower Emsian conodont ranges at section Bou Tchrafine West, which are further revised here. In the same volume, Plodowski et al. (2000) listed some new lower Emsian conodont faunas from the Jebel Issimour. Bultynck \& Walliser (2000b) added data from Achguig, which is the western prolongation of the Ouidane Chebbi outcrop belt. Fröhlich (2004) assigned some strata of the Jebel Rheris (see JRW in Fig. 2) to the lower Emsian dehiscens Zone but provided no further details. Becker \& Aboussalam (2011) and Aboussalam \& Becker (2013) published preliminary data on the lower Emsian conodont succession at Jebel Ihrs, near the western margin of the Tafilalt. Becker et al. (2013b) provided preliminary data for El Khraouia in the southern Tafilalt, Becker \& Aboussalam (2013) for the Emsian-Eifelian boundary at Jebel Amelane (western Tafilalt). The position of all mentioned Tafilalt localities is shown in Fig. 2.

New Emsian conodont data for the eastern Dra Valley were published in the last decade by P. Bultynck (in Ebbighausen et al. 2004) and K. Weddige (in Jansen et al. 2007). For the western succession there are recent records from the Oui-n-Mesdoûr Formation and the Hollardops Limestone Member (Weddige in Becker et al. 2003 and Jansen et al. 2004b, 2007; preliminary data of Aboussalam in Becker et al. 2008 and Dojen et al. 2010).

\section{Investigated localities and their conodont successions (Fig. 2)}

\section{Lower Emsian at Jebel Ihrs (Figs 3A, B, 4-10, Table 1)}

The Jebel Ihrs is in the western Tafilalt the continuation of the $c a \mathrm{~W}$-E running Jebel Amelane west of the pass formed by the main road from Rissani to Mississi (sheet Erfoud, NH-30-XX-2). Its Pragian/Emsian litho- and biostratigraphy was first outlined by Alberti (1980, 1981). Because of its dacryoconarid succession, revised in Alberti (1998), we chose it as one of the regional reference sections for Emsian conodonts. Klug (2001) noted it as a minor locality for lower Emsian ammonoids; they are locally very rare. The published upper Emsian goniatite record refers to the Jebel Amelane succession (Becker \& House 1994, Klug 2002). Becker \& Aboussalam (2011) and Aboussalam \& Becker (2013) provided a summary of the lower Emsian litho- and conodont stratigraphy, which is updated in Fig. 4 and Table 1 , including additional faunas. The GPS position for the section base is W N $31^{\circ} 16^{\prime} 11.4^{\prime \prime}$, W 4 $4^{\circ} 24^{\prime} 8.8^{\prime \prime}$.

The "Pragian Limestone" crops out at $\mathrm{ca} 75 \mathrm{~m}$ south of the main road to Msissi, opposite to a small hut right at the road (Fig. 3A). Bed 2, a solid nodular limestone, contains only a few Belodella (Fig. 5A, B). Subsequent light-grey limestones (Beds 3,4) are even more solid and yielded more belodellids at the top, in association with a single Caud. celtibericus (Carls \& Gandl, 1969). The upper part of this low limestone ridge is partly nodular, partly solid, and has no conodonts at all (Samples $6 \mathrm{~b}$ and 8c). An interval with thin-bedded alternations of marls and nodular limestones (Beds 9-14) forms a gradual transition to the mostly covered Devonobactrites Shale (Fig. 4). Despite this gradual deepening, a shallow-water belodellid biofacies prevails in Beds 10b (Fig. 5E) and 14b.

Three thin limestones beds (Beds 15b-16a) underlie the main, more massive and condensed (only $38 \mathrm{~cm}$ thick) Deiroceras Limestone (Beds 16b-d, Fig. 3A, D), which is rich in orthocones up to $2.5 \mathrm{~cm}$ in diameter. The base (Bed $15 b)$ yielded a monospecific Caud. celtibericus fauna. The nodular Bed 16a differs radically in its Caud. sigmoidalis (Carls \& Gandl, 1969) fauna (Fig. 5F) and the sudden appearance of the regionally oldest and morphologically rather diverse polygnathids ( $\mathrm{ca} 12.5 \%$ of Pa elements), of Crit. miae (Bultynck, 1971; 1.2\%, Fig. 5I), and of the first representatives of Lat. bilatericrescens (only 1.75\%; Fig. 5G, H). The sudden change of conodont biofacies is not evident in the lithofacies. The upper part of the unit (Beds 16c, d) belongs to a yet different Criteriognathus-Latericriodus-polygnathid biofacies. The sudden exclusion of Caudicriodus, especially of Caud. sigmoidalis, is remarkable and underlines the distinction of the two lower Emsian icriodid genera in terms of a different palaeoecology (facies distribution). Criteriognathus miae has become the dominant species in the lower sample (almost $40 \%$ of the fauna), Lat. bilatericrescens in the upper bed $(78 \%$ of the assemblage). Caudicriodus celtibericus re-appears as a rare form in Bed $16 \mathrm{~d}$.

The Anetoceras Limestone (Fig. 3B) begins with three thin limestones (Beds 18a-c), which belong (Sample 18b) 
to a Latericriodus biofacies with ca $30 \%$ Caudicriodus and rare Criteriognathus but without any polygnathids. Overlying more solid limestones (Bed 19) contain some crinoid debris. Subsequent thin, nodular beds are very conodont-rich (more than 800 specimens in ca $2.5 \mathrm{~kg}$ of Sample $20 \mathrm{~b}$ ), which enables to record the inception of initially rare taxa, such as Lat. beckmanni beckmannni (Ziegler, 1956) and Lat. latus (Al-Rawi, 1977). Latericriodus bilatericrescens is by far dominant (almost $90 \%$ of the fauna), followed by Crit. miae. There are only very rare Eol. excavatus. The lower part of the solid Bed 21a yielded yet another distinctive conodont biofacies, dominated jointly by Lat. bilatericrescens (ca 65\%) and Lat. beckmanni (ca 29\%). Eolinguipolygnathus and the first Crit. steinhornensis are extremely rare (one specimen each). The Latericriodus-Criteriognathus biofacies of Bed 20b returns in the nodular Bed 22b and includes the inception of two more rare taxa, Eol. catharinae (Bultynck, 1989) and Lat. beckmanni sinuatus (Klapper, Ziegler \& Mashkova, 1978).

The middle part of the Anetoceras Limestone consists of solid to massive, light-grey limestones (Beds 23b-24d, Figs 3B, 4), partly with strongly bioturbated upper surfaces. These indicate brief episodes of non-deposition (e.g., at the top of Bed 24d). In the upper part beds become thinner. In Beds 23b and 25a Crit. steinhornensis replaces Crit. miae, which is last seen in Bed 25a. Bed 23b is especially conodont-rich (more than $1200 \mathrm{~Pa}$ elements in a normal-sized, ca $2.5 \mathrm{~kg}$ sample). Despite this, there is not a single polygnathid and the diversity drops. There are placoderm bones in Bed 26d, but only three conodont taxa, including the last, rare Lat. bilatericrescens multicostatus (Carls \& Gandl, 1969) and Caud. celtibericus. This worsening of living conditions for conodonts continues at the top of the Anetoceras Limestone (Sample 27b), where the setting changes to a conodont-poor Belodella biofacies, resembling the "Pragian Limestone".

The main Mimagoniatites Limestone consists locally of massive, up to $30 \mathrm{~cm}$ thick, bluish, middle-grey limestones (Fig. 4, see also Aboussalam \& Becker 2013, fig. 6A, C). Large orthocones, including actinoceratids, are very common in the upper part (Beds 29, 30) and there are some big placoderm remains (e.g., a $30 \mathrm{~cm}$ long arm plate at the top of Bed 30). The upper surface of Bed 29 displays several Mimagoniatites cf. fecundus (Barrande, 1865). Despite the distinctive goniatite influx, which suggests a more pelagic biofacies, there are no conodonts at all. This proves an eco- logical independence of both fossil groups. The thin three beds above the main Mimagoniatites Limestone (Beds $31 \mathrm{a}_{1}, \mathrm{a}_{2}$, and 31b) are fossil-rich (many orthocones, large Panenka, more large placoderm plates) and lighter grey. Strong bioturbation and hematite incrustations testify a condensed and partly interrupted deposition, an indicator for increased bottom turbulance. The pure polygnathid biofacies of Samples $31 \mathrm{a}_{1}$ and $31 \mathrm{~b}$, however, suggests a deepening trend. It is remarkable that the two sampled beds contain different polygnathids, with a higher diversity in the lower sample, including both Eolinguipolygnathus, with dominant Eol. jacksoni (Bardashev, Weddige \& Ziegler, 2002), and Linguipolygnathus (two species) in association with some Pseudooneotodus. The top sample only contains the first genus. A stepwise deepening from Zlíchovian into Dalejan strata is also typical for the Barrandian (Ferrová et al. 2012).

The Daleje Shale Equivalents are $c a 100$ m thick and unfossiliferous. The Anarcestes Limestone is locally relatively poor in goniatites and has not been sampled for conodonts.

\section{Bou Tchrafine West (Figs 11A, 12)}

Section Bou Tchrafine West belongs to the central Tafilalt Platform. It is located in the plain SW of the Bou Tchrafine ridge about $500 \mathrm{~m}$ south of the most western point of that ridge (Figs 2, 11A), ca $8 \mathrm{~km} \mathrm{SE}$ of Erfoud ( $c a \mathrm{x}=616.6$, $\mathrm{y}=87.6$; see detailed map in Bultynck \& Walliser 2000a, fig. 4). The outcrop is relatively low. Following a rather general compilation in Hollard (1968), the Emsian stratigraphy at the Bou Tchrafine ridge was first studied in detail by Bultynck \& Hollard (1980) for conodonts and by Alberti (1980, 1981) for dacryoconarids. An updated lithological column with new conodont records was published by Bultynck \& Walliser (2000a). The new sampling comprises new, larger samples from the 1980 samples 1 to 5 and the new samples $0,0 / 1,1 b, 2 b, 4 b, 4 t$ and 6 . The sampling density is about one sample at every $0.5 \mathrm{~m}$.

Early ammonoids have been described by Becker \& House (2000) from a lateral section to the southwest, just adjacent to the road pass through the ridge. Another good lower Emsian outcrop, with rich fauna of the Devonobactrites Shale and many goniatites in the Anetoceras Limestone, lies just beneath the little bridge of the road to Erfoud, at the NW corner of Bou Tchrafine.

Figure 2. Geographic position of Emsian conodont localities in the Tafilalt and Maider (A) and Dra Valley (B). Abbreviations: OuD = Ou Driss, TnI = Tizi n'Ikouâch/Jebel Issimour, Bou-S = Boultan South, Ouh = Ouahlane (= Ouihlane), JRW = Jebel Rheris West, JI = Jebel Ihrs, JA = Jebel Amelane, BT-W = Bou Tchrafine West, BT-N/HLS = Bou Tchrafine North/Hamar Laghdad South, Ach = Achguig, OCh = Ouidane Chebbi, EKh = El Khraouia, JOu = Jebel Ouaoufilal, JKf = Jebel Kfiroun South, JeM = Jebel el-Mrier, HN = Hassi Nebech, EKs = Erg Kseir, MdK = Mdâouer-el-Kbîr, EAn = El Anhsour, Tim = Timrhanrhart, SR = Sidi Rezzoug, Ouf = Oufrane, BTs = Bou Tserfine, OuM= Oui-n-Mesdoûr, RTam = Rich Tamelougou. 

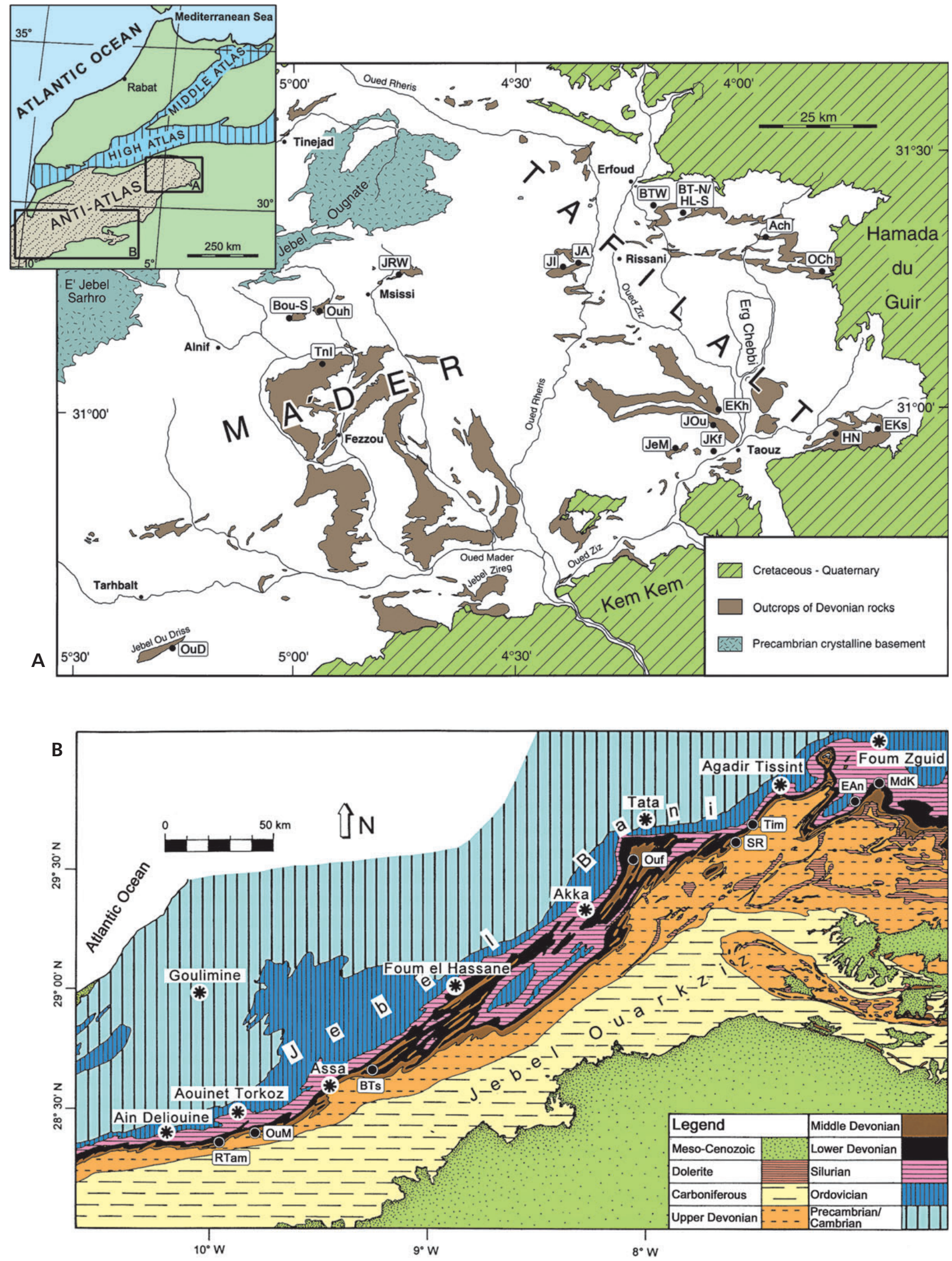
The illustrated BTW section starts with the Deiroceras Limestone (previous named as "Jovellania Beds", Fig. 12). At the base Caud. celtibericus occur together with Caud. sigmoidalis and Crit. miae. The two latter species range higher up, but Caud. celtibericus occurs only in Sample BTW0. The depositional environment is considered as a hemipelagic platform but icriodids (especially $C$. sigmoidalis) are dominating and polygnathids are rare.

Latericriodus bilatericrescens enters as a rare form in Sample BTW0/1 and becomes more common at the top (Sample BTW1), where there are also some Eol. excavatus but Caudicriodus remains far dominant (see Caud. sigmoidalis of Bultynck \& Hollard 1980, pl. I, figs 1-4).

The base of the Anetoceras Limestone has many, partly very diagnostic Latericriodus in association with common Crit. miae and rare Belodella. Higher, still in the lower part, there is a more diverse conodont fauna (Sample BTW2) with various polygnathids (including Eol. aff. gronbergi Klapper \& Johnson, 1975, Fig. 15H), four species of Latericriodus, a few Belodella, Crit. miae (Bultynck \& Hollard 1980, pl. II, figs 3, 4), and the first Crit. steinhornensis. The latter becomes dominant and replaces more and more Crit. miae (Samples BTW2b and 3), which then disappears completely (Sample BTW4). Polygnathids have disappeared in this interval, apart from a single Eol. ?gronbergi of BTW4 (figured in Bultynck \& Hollard 1980, pl. II, fig. 7). Lat. bilatericrescens becomes the only remaining but not abundant species of the genus (Samples BTW3 and 4) in this Criteriognathus biofacies.

The basal Mimagoniatites Limestone (Sample BTW $4 b$ ) is characterized by a poor, monospecific Latericriodus assemblage. The crinoidal main part of the latter (Sample BTW4t) belongs to a conodont-poor Belodella ecozone, as at Jebel Ihrs. At the top (Sample BTW6), polygnathids suddenly re-appear and are dominant at the very top (Sample BTW5), which suggests a gradual deepening towards the (main) Daleje Event. But this contrasts with thin brachiopod coquinas that are locally developed on strike towards the east.

The local conodont biofacies patterns and faunal successions strongly resemble Jebel Ihrs, with some minor differences in the Deiroceras Limestone (locally no polygnathids in the lower and fewer in the upper part) and lower Anetoceras Limestone (locally no Caudicriodus but with a few more polygnathids and Lat. armoricanus).

\section{Bou Tchrafine North (Figs 11B, 13)}

The section Bou Tchrafine North was also introduced by Bultynck \& Hollard (1980). It is located in the plain north of the Bou Tchrafine ridge, approximately $2.4 \mathrm{~km}$ northeast of the most western point of the ridge or east of the Wadi Ar Rocfa (topographic sheet, 1:50,000, Arfoud, $c a$ at $\mathrm{x}=624.4, \mathrm{y}=87.5$, Fig. $11 \mathrm{~B})$. The strike of the beds is more or less parallel with the orientation of the Bou Tchrafine ridge.

In this section there is an exposure of coarse bluish crinoidal limestones, about $10 \mathrm{~m}$ below the Deiroceras Limestone. Sample BTN P/E1 provided regionally the so far only record of Pelekysgnathus serratus serratus Jentzsch, 1962 in association with Lat. steinachensis (Al-Rawi, 1977; Fig. 17C), both morphotypes, and dominant single cone genera (Belodella, Panderodus, and Coelocerodontus). Sample BTN P/E2 yielded more Lat. steinachensis, the regionally oldest Crit. miae, and a unique, possibly new Latericriodus that is left in open nomenclature (Fig. 18S-U).

The Deiroceras Limestone changes its thickness towards the Hamar Laghdad to the east, which is noted in the lateral section in Fig. 13. Caudicriodus sigmoidalis dominates Sample BTN1. In the middle to upper parts of the unit it is joined by all three subspecies of Lat. bilatericrescens (Samples BTN BK496, BTN2-3), in association with Crit. miae, which becomes more common towards the top. Unlike the sections to the west, there are almost no polygnathids but some Lat. steinachensis with rather straight spindle, which are the youngest known globally. This faunal difference probably reflects the proximity to the elevated Hamar Laghdad mudmounds. There is a single Eol. excavatus from Sample BTN BK496, figured as Po. dehiscens Philip \& Jackson, 1967 in Bultynck \& Hollard (1980, pl. II, fig. 5a, b).

As in the previous sections, Lat. bilatericrescens also dominates the lower Anetoceras Limestone (Sample BTN4). The rather diverse assemblage, with eight species, includes some Caudicriodus, Belodella, two species of Eolinguipolygnathus (catharinae and aff. gronbergi, Fig. 15I, J), Lat. beckmanni, Lat. armoricanus Bultynck, 1989, and Crit. miae. A flood of Crit. steinhornensis enters above a very conodont-poor interval (Sample BTN BK495) in the solid middle Anetoceras Limestone, especially in Samples BTN 31-1 (Bultynck \& Hollard 1980, pl. II, figs 1,2) and 31-3, which bracket a Favosites marker unit. A similar, contemporaneous Favosites Biostrome was noted at Ouidane Chebbi further to the east (Belka et al. 1999). The rare polygnathids, Caudicriodus and Crit. miae have disappeared in this interval, whilst single cone genera become more frequent, but locally not so much Belodella. There is a last Eol. gronbergi in Sample BTN 31-4 from the upper Anetoceras Limestone (Bultynck \& Hollard 1980, pl. II, fig. 6a, b).

In the conodont-poor assemblage of Sample BTN 31-5 from the lower Mimagoniatites Limestone single cone genera remain dominant and there is a remarkably early Oz. carinthiaca. Higher, the unit yielded, as at Jebel Ihrs and Bou Tchrafine West, Eol. laticostatus (Klapper \& Johnson, 1975), but the top Samples BTN 31-6 and BTN5 had no Pa elements. 
Table 1. Upper Pragian (Beds 2-14) to lower Emsian (Beds 15b-31b) conodont record from Jebel Ihrs (western Tafilalt). Abbreviations: Mimag. = Mimagoniatites, inv. = inversus, latic. = laticostatus, U. Bel. Ez. = (local) Upper Belodella Ecozone; entry of index taxa marked in bold, * = local record interruption.

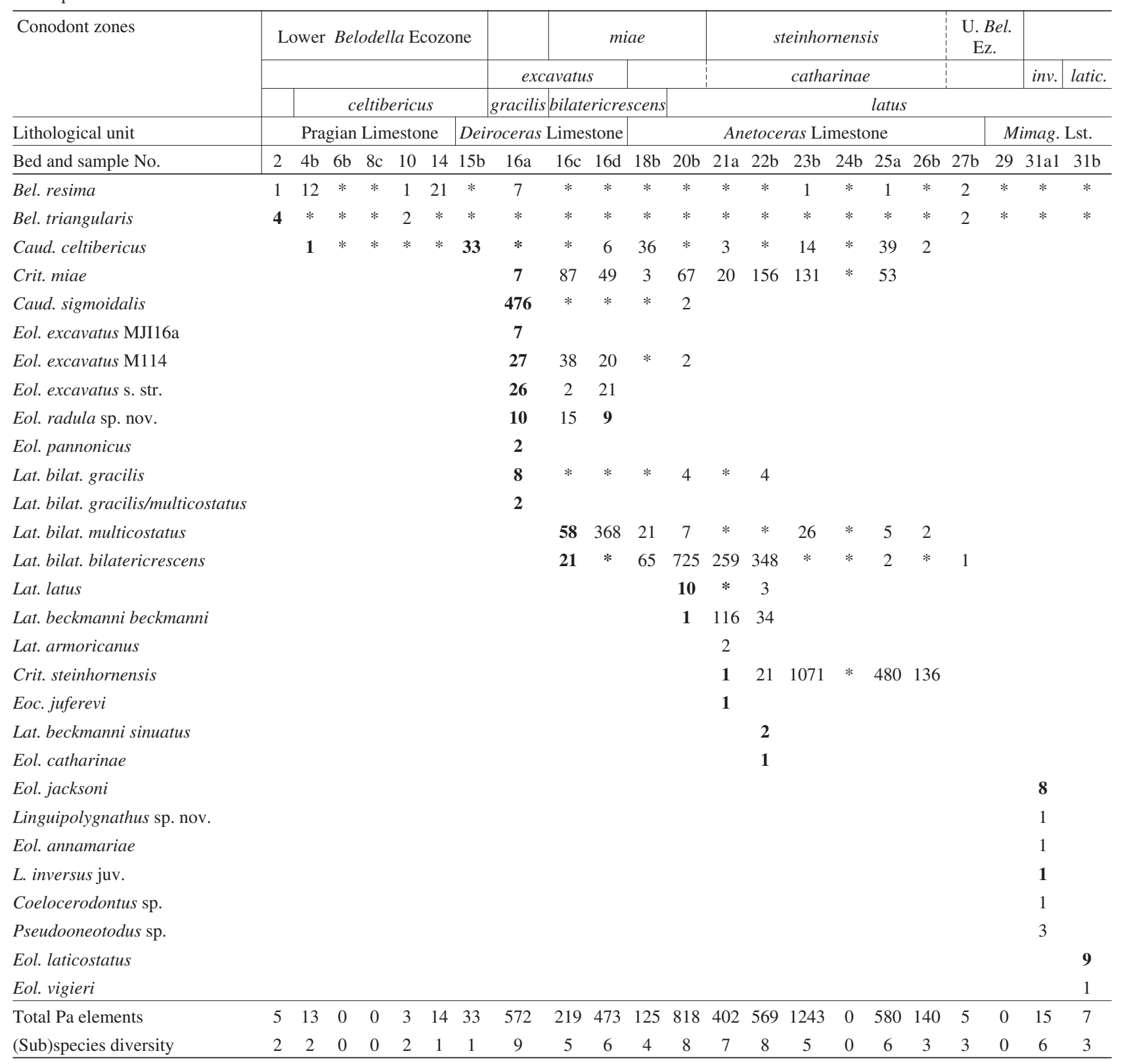

\section{Hamar Laghdad (= Hamar el Khdad) South II} (Figs 11B, 14)

This section was also first introduced by Bultynck \& Hollard (1980) and subsequently briefly discussed in Bultynck (1985). It is exposed along the northern flank of an E-W orientated ridge, about $2 \mathrm{~km}$ south-west of the Hamar Laghdad massif and forms the upwards continuation of the BTN section (Fig. 11B, see precise position in Bultynck \& Walliser 2000a, fig. 3, $x=624.55, y=89.23$ on sheet Arfoud). The outcrop shows the uppermost part of the Emsian and the lower part of the Eifelian up to the costatus conodont Zone.
The lowest part of the section consists of dark fissile shales (Unit D of Bultynck \& Walliser 2000a = Unit K, Daleje Shale Equivalents), overlain by marly nodular shales. This part did not produce conodonts but there is a succession of goethitic goniatite faunas with Gyroceratites, Rherisites and the oldest anarcestids. The overlying Unit E sensu Bultynck \& Walliser consists of shaly marls alternating with nodular limestone beds becoming progressively thicker (now Unit L, Anarcestes Limestone). In the upper half of the unit the nodular limestone beds become more important than the shales. The basal nodular beds of the Anarcestes Limestone (Samples HLS II-1 and II-2) 
yielded some L. bultyncki (Weddige, 1977) from an Icriodus-Belodella biofacies that also has common panderodontids. Polygnathids become more common upwards (Sample HLS II-4) but disappear again, leaving an $I$. rectirostratus Bultynck, 1970-Panderodus assemblage. A more solid limestone with An. lateseptatus (Sample HLS II-6) produced Po. patulus Klapper, 1971, "Oz." carinthiaca (Schulze, 1968), and others. The Emsian-Eifelian boundary can be precisely pinpointed by the earliest occurrence of Po. partitus Klapper, Ziegler \& Mashkova, 1978 in Sample HLS II-7. The top part of the Anarcestes Limestone has not been sampled.

In Unit M (= Unit F sensu Bultynck \& Walliser 2000a) the limestone beds become well stratified. Sample HL II-8 contains more Linguipolygnathus [with three species, including the first L. zieglerianus (Weddige, 1977)], than Polygnathus (costatus Group). Belodella re-appears. L. pinguis (Weddige, 1977) dominates over L. bultyncki in the following Sample HL II-9. A complete new set of Eifelian icriodids (I. amabilis Bultynck \& Hollard, 1980, I. introlevatus Bultynck, 1970, I. struvei Weddige, 1977) enters together with Po. costatus Klapper, 1971, Po. angusticostatus Wittekindt, 1966, and early Pinacites in Sample HL II-11. Bed 13 is a $35 \mathrm{~cm}$ thick marker limestone with Pinacites and Subanarcestes, which corresponds with Bed BT7 of the main Bou Tchrafine seetion of Bultynck (1985). It can be traced throughout the Tafilalt (Klug 2002, Becker \& Aboussalam 2013). Linguipolygnathus, Polygnathus, and Icriodus are ca equally common at this lower Eifelian level.

\section{El Khraouia (Figs 19-21; Table 2)}

El Khraouia is the locality name marked on sheet TaouzOuest (NH-30-XIV-4) for the sharp northern bend at the eastern end of the northern limb of the Amessoui Syncline in the southern Tafilalt, $c a 11 \mathrm{~km} \mathrm{NNW}$ of Taouz and $4 \mathrm{~km} \mathrm{E}$ of the abandoned El Atrous settlement (Fig. 2). It is named after a small settlement just to the SE. The succession $c a$ 2-3 km to the N has been named in Klug (2002) as Rich Tamirant. The high amount of shales and marls proves a palaeogeographical position at the locally short transition from the southern Tafilalt Platform to the eastern Tafilalt Basin. A corresponding small Emsian depocenter embayment has previously been noted in the isopach map of Kaufmann (1998).

The Devonian sequence dips with $\mathrm{ca} 40-50^{\circ}$ to the NE. The Lower/Middle Devonian has recently been summarized by Becker et al. (2013b). The middle part of the "Pragian Marls and Shales" (Unit D) consists of nodular marls and limestone (top of Bed 8, just below the log shown in Fig. 19), which carry abundant Lat. steinachensis, rare Lat. cf. claudiae Klapper, 1980 (in Johnson et al. 1980), and early relatives of Caud. celtibericus. Higher, there are two poorly fossiliferous limestones within Bed 9, which are separated by $3.5 \mathrm{~m}$ deeply weathered shale (Bed 10) from the "Pragian Limestone". Bed 9b (GPS position W $4^{\circ} 4^{\prime} 20^{\prime \prime}$, N $31^{\circ} 0^{\prime} 24^{\prime \prime}$, Sample MA RTB2a) is characterized by a flood occurrence of Belodella (Fig. 20E, G) accompanied by a few (<1\%) Caud. cf. curvicauda (Carls \& Gandl, 1969; Fig. 20F). The base of the overall massive "Pragian Limestone" (Bed 11a, Sample MA RTB2b) is still in Belodella biofacies, but with a higher Caudicriodus percentage (ca 12\%; this time Caud. celtibericus) and with some Pseudooneotodus. A sample from the top of this widely visible low cliff (Bed 11g) was barren. Above, a thin light-grey limestone from near the top of the predominantly marly Bed $13 \mathrm{~b}$ continues the Belodella-Caud. celtibericus assemblage.

The almost 10 m thick Devonobactrites Shale (Bed 14) begins locally with nodular marls with a rich neritic fauna, including trilobites (phacopids, scutelluids), small brachiopods, and branching tabulate corals (Thamnopora). The typical goethitic "Faunule 1" with early bactritids occurs in the upper part. The overlying ca $2 \mathrm{~m}$ thick Deiroceras Limestone consists of mostly massive, grey limestones with orthocones. At the base, Bed 15a (Sample MA RTB3) yielded a single polygnathid among hundreds of belodellids and icriodids. Neopanderodus specimens amount to ca $6 \%$ (Fig. 21A) of this Belodella-Caudicriodus assemblage, Criteriognathus and Latericriodus each only to less than $2 \%$. In other words, the stratigraphically important index conodonts are rare. A thin-bedded limestone from the middle Deiroceras Limestone (Bed 15c) contains an equally diverse association with fewer belodellids (only $c a$ $15 \%$ ), more dominant Caud. sigmoidalis (70\%), and three more Eol. excavatus. The conodont biofacies changes markedly at the top of the Deiroceras Limestone (Bed 15f) to a relatively diverse (ten taxa) Latericriodus Assemblage with more than $10 \%$ polygnathids, Panderodus, and Crit. miae. The decline of belodellids and Caudicriodus suggests a deepening trend, which culminates in the locally not very fossiliferous Metabactrites-Erbenoceras Shale (Bed 16).

The Anetoceras Limestone begins with $\mathrm{ca} 50 \mathrm{~cm}$ solid limestone (Bed 17), followed by a shale and solid limestone (Bed 18), and ends with $c a 85 \mathrm{~cm}$ of thin-bedded limestones with some phacopids and Erb. advolvens (Bed 19). Despite the pelagic platform facies, there were no conodonts at all in a sample from Bed 17c. The biofacies appears to be strongly oligotrophic. A mostly covered shale unit (Bed 20) separates the $4.7 \mathrm{~m}$ thick, darker-grey, mostly nodular and crinoidal Mimagoniatites Limestone. Again, there are hardly any conodonts (base of the nodular Bed 21a). The light-grey top bed (top Bed 22) yielded a shallow-water Belodella-Neopanderodus assemblage with subordinate ( $\mathrm{ca}$ 20\%) polygnathids and Caudicriodus. As 
in the western and central Tafilalt, this new influx of polygnathids indicates a deepening at the end of the lower Emsian.

The Daleje Shale Equivalents are more than $100 \mathrm{~m}$ thick. Exposures are restricted to small ravines in the western steep slope of the ridge formed by Eifelian limestones. Still in the lower part of the slope there is a peculiar, thin trilobite bed and marly limestone, which did not produce any conodonts. In the middle of the cliff, the yellowish weathering, nodular, goniatite-rich Anarcestes Limestone is poorly exposed. Therefore, it is locally difficult to measure a detailed upper Emsian section.

\section{Hassi Nebech (Figs 19, 22; Table 3)}

The extensive Devonian outcrops at Hassi Nebech, ca $20 \mathrm{~km}$ ENE of Taouz (sheet Taouz-Est, NH-30-XV-3), belong to the Tafilalt Basin. The Givetian to Famennian interval has become famous for its ammonoid faunas (Bensaid 1974; Becker et al. 2002; Bockwinkel et al. 2002, 2013) but there is hardly any literature on the upper Silurian, Lower Devonian and Eifelian strata, which are also well exposed. Klug (2002) mentioned a few Achguigites specimens, as evidence for the lower Anarcestes Limestone.

Above 15-16 m Lochkovian to Pragian thin limestones and predominant marls, which indicate condensed marginal platform, not basinal conditions at that time, there is a superb sequence of very trilobite-rich, nodular "Pragian Limestone" (Fig. 19). A $55 \mathrm{~cm}$ unit of solid limestone (Bed 11) forms the base; it yielded no conodonts (Sample

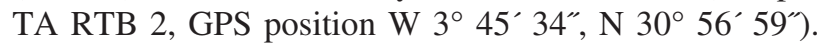
Fluctuating abundances of different trilobite and other faunal groups provide an ecostratigraphical subdivision into marker beds with Crotalocephalina (Bed 12), corals and Lamellorthoceras (Bed 13), Reedops ( $1^{\text {st }}$ and $2^{\text {nd }}$ trilobite coquina of Beds 14/15), large orthocones (Bed 16), and scutelluids (Bed 17b). The upper part of the $c a 12 \mathrm{~m}$ thick succession is less fossiliferous. A lenticular coral limestone with many orthocones and Tabulata forms a distinctive low mound in the transition to the poorly exposed Devonobactrites Shale. Conodont samples from the lower (Bed 11c) and middle parts (Bed 19b) were barren. Sample TA RTB 4 from Bed 22c produced a rich shallow-water conodont assemblage dominated by Belodella (Fig. 22L, M), but with ca $17 \%$ diagnostic Caud. celtibericus (Fig. 22N) that are partly transitional from Caud. curvicauda. The thin limestone (Bed 24b, Sample TA RTB 5) below the low coral mound produced just one Belodella. At the top of the slope, above a sand field, a neritic lower Emsian platform setting re-appears as thick, massive, bluish-grey Deiroceras Limestone with planispiral, involute gastropods and orthocones. As in the Tafilalt Platform sections, it is dominated by Caud. sigmoidalis (72\%), followed by
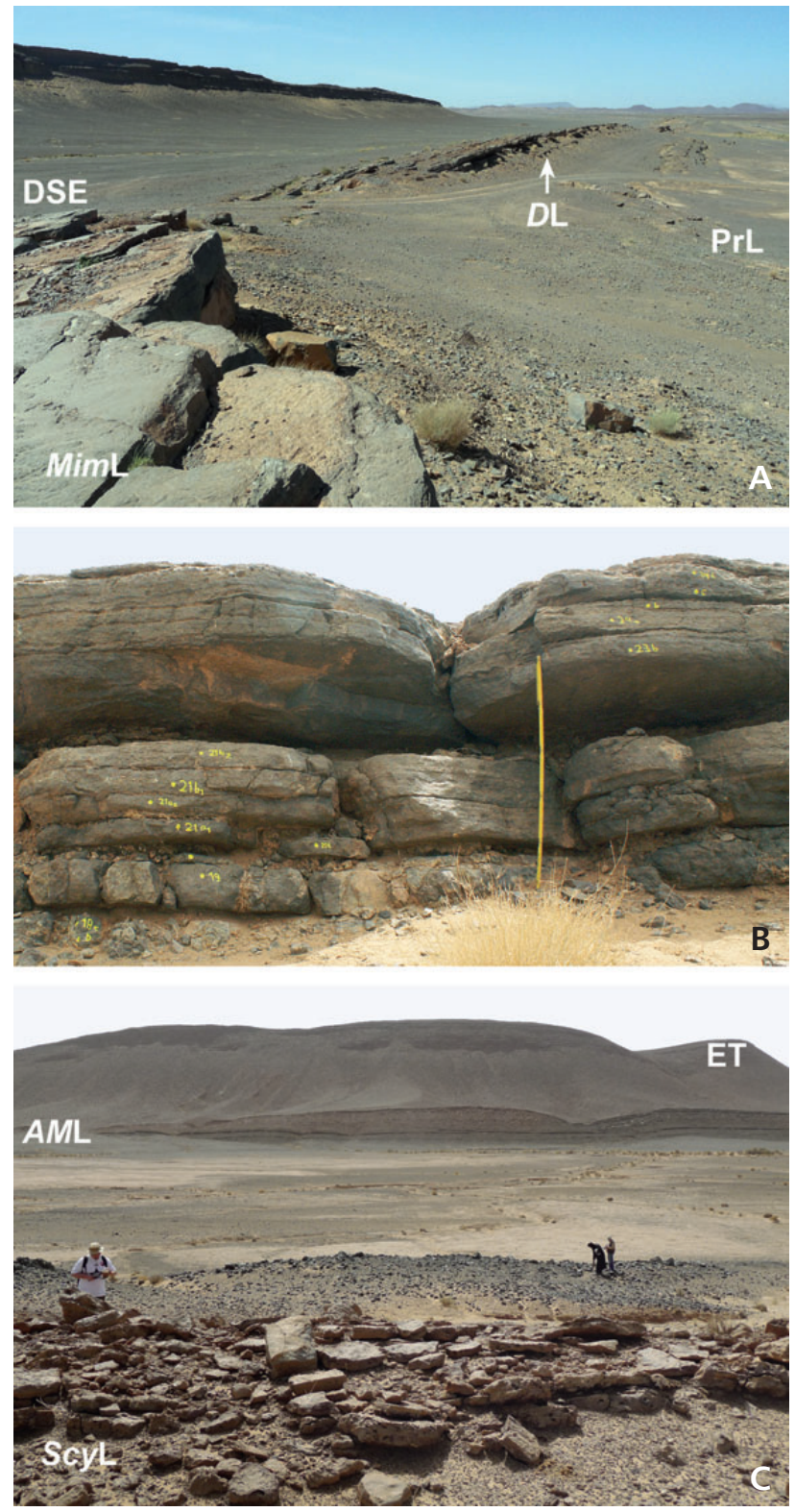

Figure 3. Lower Devonian strata at Jebel Ihrs and Jebel el-Mrier. - A - succession at Jebel Ihrs from the "Pragian Limestone" (PrL right), Deiroceras Limestone ( $D \mathrm{~L}$ - arrow) to the massive Mimagoniatites (MimL - left foreground), Daleje Shale Equivalents (DSE), to the upper Emsian/Eifelian cliff (background). $\bullet$ B - details of the Anetoceras Limestone at Jebel Ihrs, showing bed numbers and the incision below Bed 23b. $\cdot \mathrm{C}$ - overview of the Lower Devonian at Jebel el-Mrier, with the lower Lochkovian Scyphocrinites Limestone (ScyL) in the foreground, the low cliff of the Anetoceras and Mimagoniatites Limestone $(A M \mathrm{~L})$ in the middle ground, including the Deiroceras Limestone as a continuous solid interval in the lower third of the slope, and the high cliff of Daleje Shale Equivalents to Eifelian turbidites (ET) in the background.

Belodella (ca 23\%; Sample TA RTB 6). A single Eol. excavatus M114 conforms with the other Deiroceras Limestone localities. 
In a wide depression towards the $\mathrm{S}$, the Daleje Shale Equivalents are locally very thick and poorly fossiliferous. The yellowish weathering, nodular Anarcestes Limestone is exposed in the lower part of the next ridge, which top is formed by Eifelian turbiditic limestones. At the base Sell. wenkenbachi is common in nodules (Bed 28), followed by somewhat more solid light-grey limestone with Sell. wenkenbachi, Sell. ebbighauseni Klug, 2002, An. simulans (Barrande, 1865), and phacopids (Bed 29), a peculiar, goniatite-rich Achguigites Marl (Bed 30, also with Sell. neglectus), and grey limestones with dominant Anarcestes (Bed 31). Loose anarcestids found around Bed 29 were dissolved as a conodont sample. It is surprising that assumed shallow-water genera (Neopanderodus and Belodella) are more common in such a hemipelagic lithofacies and macrofauna assemblage than polygnathids and icriodids. This affects the ammonoid-conodont correlation (see "Ammonoid-conodont correlation in the Tafilalt") and indicates a shift or restriction of the main habitat of these genera in time, especially from the Lower to Middle Devonian.

\section{Jebel el-Mrier (Figs 3C, 22; Table 3)}

The Jebel el-Mrier forms a southwards opening syncline $c a$ $13.5 \mathrm{~km} \mathrm{~W}$ of Taouz, $c a 9 \mathrm{~km} \mathrm{~S}$ of the Amessoui Syncline, and $c a 6 \mathrm{~km}$ NNE of Jdaid. Lochkovian to Pragian limestones and shales lie at the base of the section. The "Pragian Limestone" is locally a condensed, only ca $60 \mathrm{~cm}$ thick marker unit with poor macrofauna. Sample AL RTB 5 (GPS position 49 $9^{\prime} 47^{\prime \prime}$, N $30^{\circ} 54^{\prime} 40^{\prime \prime}$ ) from the top of the unit was barren. The ca $4.5 \mathrm{~m}$ thick Devonobactrites Shale is interrupted in its lower part by two thin layers of crinoidal nodular limestone. The Deiroceras Limestone forms a marked ridge of massive, light-grey limestones with crinoidal debris (Fig. 3C) within a lower Emsian slope. Beds are between 25 and $35 \mathrm{~cm}$ thick and dip in the measured section with $24^{\circ}$ to the SE. The top (Sample AL RTB 6) is in Caudicriodus biofacies, with ca $20 \%$ Lat. bilatericrescens and $15 \%$ Belodella. The Metabactrites-Erbenoceras Shale is locally also rather unfossiliferous; it contains only a few orthocones. The Anetoceras Limestone consists of medium-bedded, light-grey limestone with orthocones, especially in the lower part and in a $20 \mathrm{~cm}$ thick massive bed at the top. There are only a few goniatites. Teicherticeras, which elsewhere in the Tafilalt is extremely rare, is locally the most obvious goniatite. Conodont faunas from the middle and upper part of the unit (Samples AL RTB 7a and 7b) are dominated by Criteriognathus (up to $67 \%$ of the faunas), followed by Latericriodus or Belodella. Polygnathids are absent. The overlying Mimagoniatites Limestone is separated by a recessive $1 \mathrm{~m}$ interval of thin-bedded limestones. Conodont samples from the base (AL RTB 8) and top (AL RTB 9a and 9b) are in shallow-water biofacies, with dominant Neopanderodus (Fig. 22E, H), accompanied by a few or abundant (AL RTB 9b) Belodella. For all of the Tafilalt, there is an exceptional (single) polygnathid from the lower Mimagoniatites Limestone and a single Crit. steinhornensis (Fig. 22J) from the top. The differences of goniatite and conodont faunas suggest a somewhat shallower setting then in the Tafilalt sections to the north and east. The upper Emsian strata have not been studied in detail since they are widely covered by debris from the overhanging Eifelian limestone cliff.

\section{Jebel Kfiroun South}

The Jebel Kfiroun is a $c a \mathrm{~W}-\mathrm{E}$ running ridge $\mathrm{SW}$ and $\mathrm{S}$ of Taouz (sheet Taouz-Ouest, NH-30-XIV-4; Fig. 2). A small hill between the main ridge and the piste from Taouz to Jdaid, ca $3.5 \mathrm{~km} \mathrm{SW}$ of Taouz, exposes a vertical Lower Devonian sequence capped unconformably by the upper Famennian Gonioclymenia Limestone. The "Pragian Limestone" is locally ca $3 \mathrm{~m}$ thick, followed by the deeply weathered and mostly covered Devonobactrites Shale. The Deiroceras Limestone is massive and $c a 1 \mathrm{~m}$ thick, the locally unfossiliferous Metabactrites-Erbenoceras Shale deeply weathered and ca $2 \mathrm{~m}$ thick. The light-grey Anetoceras Limestone consists of $c a 65 \mathrm{~cm}$ solid limestones in the lower part, with an orthocone-rich $20 \mathrm{~cm}$ limestone at the top, and $c a 1 \mathrm{~m}$ of nodular, more thin-bedded limestone. The ca $50 \mathrm{~cm}$ thick Mimagoniatites Limestone is darker grey, it contains abundant Mimagoniatites sp., bivalves (Panenka), phacopids, and orthocones at the top. Sample AL RTB 11 (GPS position W 4 2' 19", N 30 53' 8') from the lower part yielded almost only Neopanderodus. Sample AL RTB 12 from the upper massive marker limestone was barren, as at Jebel Ihrs but in contrast with the presence of goniatites. The rarity of conodonts suggests a further shallowing of the palaeoenvironment, extending from the Jebel el-Mrier towards the east. The Daleje Shale Equivalents are more than $50 \mathrm{~m}$ thick below the mentioned unconformity. Intercalated thin limestones near the top carry no conodonts (Sample AL RTB 13).

\section{Jebel Ouaoufilal}

The Jebel Ouaoufilal (= Jebel Aoufilal) is the elongated southeastern extension of the Amessoui Syncline, from $\mathrm{ca}$ $4.5 \mathrm{~km} \mathrm{NW}$ of Taouz on. Following first detailed studies by Klug (2001, 2008), Kröger (2008) investigated the local Lower Devonian succession and its nautiloid faunas. Recently, Klug et al. (2013) provided a summary of the Lochkovian to Eifelian of the ridge. Two conodont samples were taken during the spring 2013 field trip day led by 
Table 2. Conodont record of lower Emsian samples from El Khraouia. Abbreviations: Prag. = Pragian, Anet Lst. = Anetoceras Limestone, gracilis $=$ bilatericrescens gracilis, bilat. = bilatericrescens bilatericrescens. Entry of index taxa marked in bold.

\begin{tabular}{|c|c|c|c|c|c|c|c|c|c|c|c|}
\hline \multirow{3}{*}{ Conodont zones } & & \multicolumn{4}{|c|}{ Lower Belodella Ecozone } & \multirow{2}{*}{\multicolumn{3}{|c|}{$\frac{\text { miae }}{\text { excavatus M114 }}$}} & & & \multirow{3}{*}{ laticostatus } \\
\hline & & & & & & & & & & & \\
\hline & \multicolumn{2}{|c|}{ steinachensis } & \multicolumn{3}{|c|}{ celtibericus } & \multicolumn{2}{|c|}{ gracilis } & bilat. & & & \\
\hline Lithological unit & \multicolumn{2}{|c|}{ Prag. Marl/Shale } & \multicolumn{3}{|c|}{ Pragian Lst. } & \multicolumn{3}{|c|}{ Deiroceras Lst. } & Anet. Lst. & \multicolumn{2}{|c|}{ Mimagoniatites Lst. } \\
\hline Sample No. & & MA 2a & MA $2 b$ & & & MA 3 & & & & & \\
\hline Bed No. & top 8 & $9 \mathrm{~b}$ & $11 \mathrm{a}$ & $11 \mathrm{~g}$ & 13 Top & $15 \mathrm{a}$ & $15 \mathrm{c}$ & $15 \mathrm{f}$ & $17 \mathrm{c}$ & $21 \mathrm{a} 1$ & 22 Top \\
\hline Lat. steinachensis & 63 & & & & & & & & & & \\
\hline Lat. claudiae & 2 & & & & & & & & & & \\
\hline Caud. ?celtibericus & 18 & & & & & & & & & & \\
\hline Bel. resima & & 530 & 76 & $*$ & 57 & 304 & 38 & 1 & $*$ & $*$ & 44 \\
\hline Bel. triangularis & & 6 & 2 & & & & & & & & \\
\hline Caud. curvicauda & & $4 \mathrm{cf}$. & $*$ & $*$ & $*$ & $*$ & 4 & & & & \\
\hline Caud. celtibericus & & & 11 & $*$ & 5 & 16 & 21 & 2 & & & \\
\hline Pseudo. beckmanni & & & 5 & & & & & & & & \\
\hline Crit. miae & & & & & & 7 & 1 & 27 & & & \\
\hline Eol. excavatus M114 & & & & & & 1 & 3 & 8 & & & \\
\hline Neop. perlineatus & & & & & & 33 & $*$ & $*$ & $*$ & 1 & 21 \\
\hline Lat. bilat. gracilis & & & & & & 10 & 2 & 13 & & & \\
\hline Caud. sigmoidalis & & & & & & 168 & 177 & 4 & & & \\
\hline Panderodus sp. & & & & & & 1 & & & & & \\
\hline Eol. excavatus s. str. & & & & & & & 6 & 16 & & & \\
\hline Lat. bilat. multicostatus & & & & & & & & 55 & & & \\
\hline Lat. bilat. bilatericrescens & & & & & & & & 95 & & & \\
\hline Eol. radula sp. nov. & & & & & & & & 1 & & & \\
\hline Caud. ultimus & & & & & & & & & & & 2 \\
\hline Eol. laticostatus & & & & & & & & & & & 3 \\
\hline Eol. gilberti & & & & & & & & & & & 1 \\
\hline L. inversus & & & & & & & & & & & 9 \\
\hline Eoc. cf. juferevi & & & & & & & & & & & 2 \\
\hline Eol. vigieri & & & & & & & & & & & 1 \\
\hline Eol. cf. vigierei & & & & & & & & & & & 1 \\
\hline Total conodonts & 83 & 540 & 89 & 0 & 59 & 540 & 252 & 222 & 0 & 1 & 82 \\
\hline (Sub)species diversity & 3 & 3 & 4 & 0 & 2 & 8 & 8 & 10 & 0 & 1 & 6 \\
\hline
\end{tabular}

C. Klug (Klug et al. 2013). The top of the "Pragian Limestone" yielded, as in other sections, mostly Belodella (thirty-one Bel. resima, six Bel. triangularis). In addition there are nine Caud. curvicauda as the only icriodid. The top of the Mimagoniatites Limestone produced just a single Neop. perlineatus Ziegler \& Lindström, 1971, which suggests a northward extension of the shallow pelagic lower Emsian platform of the southern Tafilalt.

\section{Eastern Dra Valley}

Bultynck \& Hollard (1980) studied conodont samples from four sections of the eastern Dra Valley, from east to west (Fig. 2) Mdâouer-el-Kbîr, El Annsa, Foum Timrhanrhart, and Targa Kheniga. We present updates for two sections.
The Mdâouer-el-Kbîr ridge, $c a 22 \mathrm{~km}$ south of Foum Zguid, has a beautiful erosional landscape (Fig. 23A) and is the type locality for the Mdâouer-el-Kbîr Formation. At the bottom of Fig. 24 the results of a sample from about $60 \mathrm{~m}$ above the base of the formation are shown. In that sample L. aff. inversus (Klapper \& Johnson, 1975) occurs together with Caud. celtibericus ("subsp. A" in Bultynck \& Hollard, 1980, pl. I, fig. 25) and Lat. bilatericrescens, indicating a lower Emsian age.

The part of the El Anhsour section (El Annsa) studied herein is exposed in a cliff face about $30 \mathrm{~km} \mathrm{SSW} \mathrm{of} \mathrm{Foum}$ Zguid (Figs 23B, 24). The lowest part belongs to the uppermost part of the Upper Member of the Mdâouer-el-Kbîr Formation (Hollard 1978). The overlying part belongs to the Lower Member of the Timrhanrhart Formation (Hollard 1978). Brachiopod coquinas at the top of the Rich 
Table 3. Lower Emsian conodont record of samples from Hassi Nebech, Jebel el-Mrier, and Jebel Kfiroun. Abbreviations: Prag. Lst. = "Pragian Limestone", Deiro. = Deiroceras Limestone, Anet. Lst. = Anetoceras Limestone, excav. = excavatus Morphotype 114, bilat. = bilatericrescens bilatericrescens, J. Kfir. = Jebel Kfiroun South, U. Bel. Ez. = Upper Belodella Ecozone. Entry of index taxa marked in bold.

\begin{tabular}{|c|c|c|c|c|c|c|c|c|c|c|c|}
\hline \multirow{3}{*}{$\begin{array}{l}\text { Conodont zones } \\
\text { Locality }\end{array}$} & \multirow{2}{*}{\multicolumn{2}{|c|}{ celtibericus }} & excav. & & excav. & \multicolumn{5}{|c|}{ gronbergi } & \\
\hline & & & bilat. & & bilat. & \multicolumn{4}{|c|}{ steinhornensis } & \multicolumn{2}{|c|}{ / U. Bel. Ez. } \\
\hline & \multicolumn{3}{|c|}{ Hassi Nebech } & \multicolumn{7}{|c|}{ Jbel El Mrier } & J. Kfir. \\
\hline Lithostratigraphy & \multicolumn{2}{|c|}{ Prag. Lst. } & Deiro. & Prag. Lst. & Deiro. & \multicolumn{2}{|c|}{ Anet. Lst. } & \multicolumn{4}{|c|}{ Mimagoniatites Limestone } \\
\hline Bed No. & $22 \mathrm{c}$ & $24 b$ & & & & & & & & & \\
\hline Sample No. & TA4 & TA5 & TA6 & AL5 & AL6 & AL7a & AL7b & AL8 & AL9a & AL9b & AL11 \\
\hline Caud. celtibericus & 31 & $*$ & 3 & & & 28 & & & & & \\
\hline Bel. resima & 124 & 1 & 22 & & 2 & 48 & 1 & 3 & 7 & 30 & 1 \\
\hline Bel. triangularis & 15 & & & & & & & & & 3 & \\
\hline Neopand. perlineatus & 14 & $*$ & 1 & & & 19 & $*$ & 18 & 47 & 70 & 24 \\
\hline Caud. sigmoidalis & & & 70 & & 9 & & & & & & \\
\hline Eol. excavatus M114 & & & 1 & & & & & & & & \\
\hline Lat. bilat. bilatericrescens & & & & & 3 & 1 & & & & & \\
\hline Crit. steinhornensis & & & & & & 218 & 16 & $*$ & $*$ & 1 & \\
\hline Lat. bilat. multicostatus & & & & & & 41 & 7 & & & & \\
\hline Eol. cf. gronbergi & & & & & & & & 1 & & & \\
\hline (Sub)species diversity & 4 & 1 & 5 & 0 & 3 & 6 & 3 & 3 & 2 & 4 & 2 \\
\hline Total conodonts & 184 & 1 & 97 & 0 & 14 & 355 & 24 & 22 & 54 & 104 & 25 \\
\hline
\end{tabular}

3 Member of the Mdâouer-el-Kbîr Formation are in icriodid biofacies. Sample I is dominated by I. fusiformis Carls \& Gandl, 1969 (Fig. 25A-D) and Caud. culicellus culicellus Bultynck, 1976, with some I. corniger ancestralis Weddige, 1977, and with rare I. ovalis sp. nov. (Fig. 25E-G). Sample II belongs to a shallower biofacies with many Panderodus and dominant Caud. culicellus culicellus (Fig. 25J-L). Latericriodus beckmanni sinuatus occurs throughout the section. The Lower Member of the Timrhanrhart Formation is locally developed as an alternation of shales and thin limestones, which are rich in phacopids in higher parts. This Trilobite Limestone can be followed westwards to the Tata region (e.g., Ebbighausen $e t$ al. 2004, 2011). Sample 2 from at El Anhsour yielded a relatively diverse Caudicriodus-Panderodus assemblage with subordinate Latericriodus (ca 5\%) and Icriodus (18.5\%), including I. ovalis sp. nov. and I. praerectirostratus sp. nov. (Fig. 25R-X). A higher thin limestone (Sample 8) differs by its Panderodus-I. rectirostratus association, with subordinate Belodella and Caud. culicellus culicellus (both ca 5\%). This conodont biofacies is maintained at the top of the Trilobite Limestone (Sample 14) and at the base of the overlying Sellanarcestes Limestone (Sample 16) but I. rectirostratus becomes more abundant than Panderodus. Linguipolygnathus inversus (Fig. 25AB, AC) and $L$. aff. inversus (Fig. 25Z, AA) re-appear just below and in the first massive Sellanarcestes Limestone (Samples 14 and 16) whilst there are still no typical upper Emsian polygnathids. The top of the massive goniatite limestone (Sample 19b) is very poor in conodonts, with just two Lat. beckmanni sinuatus (Fig. 25Y) and two I. rectirostratus.
The conodont fauna from the El Anhsour section (Fig. 25) is very similar to the conodont fauna of the Scheidt Formation described by Weddige \& Requadt (1985) from the Rhenish Massive. The Scheidt Formation occurs between Koblenz and Limburg an der Lahn. It belongs to the lower part of the Upper Emsian in its original sense. Icriodus homorectus Weddige, 2003 was originally described from that area and is recognized for the first time in the Anti-Atlas (Samples II and 2). The conodont fauna from El Anhsour is not found in the Tafilalt because it corresponds to the Daleje Shale Equivalents, for example between sections BTN and HLS II.

\section{Western Dra Valley (Figs 26, 27; Table 4)}

The western Dra Valley includes, from east to west, over more than $200 \mathrm{~km}$ distance (Fig. 1) an extensive series of sections exposed in Lower Devonian folds (Hollard \& Jaquemont 1956, Lubeseder et al. 2008, Ouanaimi \& Lazreq 2008). Bultynck \& Hollard (1980) included conodont samples, from east to west, from Tjafane, Oui-n-Mesdoûr, and Hassi Talha. Our detailed biostratigraphic work has concentrated on sections near Assa and to the SW of Torkoz.

The succession at Bou Tserfine (sheet Assa, NH-29-III-4, Figs 26, 27) was described by Becker et al. (2004c). Our numbering adopts the letters used in the published section $\log$, which is updated here. Subsequent conodont data were mentioned in preliminary notes of Becker et al. (2008) and Dojen et al. (2010). Brett et al. (2012) illustrated and interpreted the strongly cyclic lime- 
Table 4. Emsian conodonts from samples of the western Dra Valley. Abbreviations: Akh. T. Mbr. = Akhal Tergoua Member, Bl. Marl = Black Marl Member, Brach. Marl Mbr. = Brachiopod Marl Member, Sell Lst. = Sellanarcestes Limestone, bilatericr. Ecoz. $=$ local bilatericrescens bilatericrescens Ecozone. Entry of index taxa marked in bold.

\begin{tabular}{|c|c|c|c|c|c|c|c|c|c|c|c|c|c|c|c|c|c|c|}
\hline \multirow{4}{*}{$\begin{array}{l}\text { Locality } \\
\text { Zones } \\
\text { Lithostratigraphy } \\
\text { Bed or sample No. }\end{array}$} & \multicolumn{6}{|c|}{ Bou Tserfine } & \multicolumn{12}{|c|}{ Rich Tamelougou } \\
\hline & \multirow{3}{*}{\begin{tabular}{|c|} 
latus \\
Akh. T. \\
A10b \\
\end{tabular}} & \multicolumn{2}{|c|}{ bilatericr. Ecoz. } & \multicolumn{3}{|c|}{ fusiformis } & \multirow{3}{*}{\begin{tabular}{|c|} 
latus \\
Akh. T. \\
base \\
\end{tabular}} & \multicolumn{11}{|c|}{ fusiformis } \\
\hline & & \multirow{2}{*}{\begin{tabular}{|c|} 
B1. Marl \\
A18b \\
\end{tabular}} & \multicolumn{4}{|c|}{ Hollardops Limestone } & & \multicolumn{7}{|c|}{ Hollardops Limestone } & \multicolumn{3}{|c|}{ Brach. Marl Mbr. } & \multirow{2}{*}{$\begin{array}{c}\text { Sell. Lst } \\
\mathbf{X}\end{array}$} \\
\hline & & & D1 & D38 & D91b & top D & & base & 3 & main & 9 & 35 & 61 & 105 & 161 & $161+1 \mathrm{~m}$ & "Latan." & \\
\hline Lat. beckmanni beckmanni & 6 & & & & & & 2 & & & & & & & & & & & \\
\hline Lat. bilat. bilatericrescens & 12 & 11 & 5 & & & & 12 & $*$ & $*$ & 12 & & & & & & & & \\
\hline Bel. resima & 1 & & & & & & 4 & $*$ & 1 & 26 & $*$ & $*$ & $*$ & 1 & 5 & 4 & & \\
\hline Caud. sigmoidalis & 8 & & & & & & 11 & & & & & & & & & & & \\
\hline Caud. cf. ultimus & 15 & & & & & & 12 & 2 & & & & & & & & & & \\
\hline I. corniger leptus & & & & 1 & 2 & $1 ?$ & & & & 9 & $*$ & $1 ?$ & & & & & & \\
\hline Caud. culicellus altus & & & & & $1 ?$ & & & & & & & & & & & & & \\
\hline Neop. perlineatus & & & & & 1 & & 2 & $*$ & 3 & 3 & 2 & 4 & $*$ & 4 & 1 & & & \\
\hline Caud. celtibericus & & & & & & & 2 & & & & & & & & & & & \\
\hline Lat. beckmanni sinuatus & & & & & & & 4 & & & & & & & & & & & \\
\hline Bel. triangularis & & & & & & & 3 & & & & & & & & & & & \\
\hline Eol. excavatus M114 & & & & & & & 1 & & & & & & & & & & & \\
\hline I. rectirostratus & & & & & & & & 1 cf. & $*$ & 1 & & & & & & & & \\
\hline Panderodus sp. & & & & & & & & 1 & $*$ & $*$ & $*$ & $*$ & $*$ & $*$ & $*$ & $*$ & $*$ & 2 \\
\hline Caud. ultimus & & & & & & & & & 1 & 22 & $*$ & $*$ & 4 & 3 & 2 & & & \\
\hline I. cf. werneri & & & & & & & & & & 1 & & & & & & & & \\
\hline Caud. aff. sigmoidalis & & & & & & & & & & 3 & & & & & & & & \\
\hline Caud. culicellus culicellus & & & & & & & & & & 5 & & & & & & & & \\
\hline I. corniger ancestralis & & & & & & & & & & & $1 ?$ & & & & & & & \\
\hline Icriodus sp. & & & & & & & & & & & & & & & & 1 & & \\
\hline Caud. aff. celtibericus & & & & & & & & & & & & & & & & & 1 & \\
\hline Total conodonts & 43 & 11 & 5 & 1 & 4 & 1 & 53 & 4 & 5 & 82 & 3 & 5 & 1 & 3 & 3 & 5 & 1 & 2 \\
\hline (Sub)species diversity & 5 & 1 & 1 & 1 & 3 & 1 & 9 & 3 & 3 & 9 & 2 & 2 & 4 & 8 & 8 & 2 & 1 & 1 \\
\hline
\end{tabular}

stone-marl alternation of the Hollardops Limestone Member. The Emsian section starts at GPS N 28³9' 19.6", W $9^{\circ} 16^{\prime} 9.3^{\prime \prime}$ with the last, thick- and cross-bedded Rich 2 sandstones (Fig. 26, Beds $\mathrm{A}_{0}-\mathrm{A}_{5}$ ). Calcareous siltstones form a gradual transition and lower subunit of the Akhal Tergoua Member (Beds $\mathrm{A}_{6}, \mathrm{~A}_{7}$ ). The slightly calcareous top of Bed $\mathrm{A}_{2}$ was unsuccessfully sampled for conodonts. A thin phosphatic lag deposit at the top of the marly Bed $\mathrm{A}_{6}$ contains ostracodes, bryozoans, dacryoconarids, and trilobite debris, but no conodonts. The middle subunit (Beds $\mathrm{A}_{8}-\mathrm{A}_{12}$ ) consists of solid dark-grey limestones with many Zoophycus and intercalated dark marls with abundant Odontochile sp. in specific layers (e.g., Bed $\mathrm{A}_{11}$ ), which provided the name "Calcaire noir à Odontochile" on the geological map. Bed $\mathrm{A}_{10 \mathrm{~b}}$, a rather massive marker limestone, is in moderately rich icriodid biofacies, with almost equal representation of Latericriodus and Caudicriodus (two species each). The upper unit of the Akhal Tergoua Member consists of predominant dark-grey marls, with black, more calcareous and dacryoconarid-rich beds at the top of four cycles $\left(\mathrm{A}_{14}, \mathrm{~A}_{15}, \mathrm{~A}_{17 \mathrm{~b}}, \mathrm{~A}_{18 \mathrm{~b}}\right)$. Bed
$\mathrm{A}_{18 \mathrm{~b}}$ at the boundary to the overlying Black Marl Member (Unit B) yielded a small, monospecific Latericriodus fauna. The subsequent black marls are not calcareous enough for conodont sampling but contain abundant dacryoconarids and some small brachiopods. The poorly exposed upper part of the member includes packages of lighter-grey marls (Unit C).

The basal Hollardops Limestone Member (Unit D, section $\log$ in Becker et al. 2004c) consists of alternating dark-grey marls and argillaceous nodular limestone with some phacopids and large, up to $20 \mathrm{~cm}$ long orthocones. Becker et al. (2008) correlated this hypoxic interval with the initial Daleje Event. The first limestone $\left(B e d D_{1}\right)$ continues the monospecific Latericriodus fauna from below. Further conodont samples through the member were taken from the base of the interval with increasingly abundant trilobites (Bed $\mathrm{D}_{38}$ : only one Icriodus corniger leptus Weddige, 1977), from a more solid limestone (Bed $\mathrm{D}_{54}$ : barren), and from the concretionary Bed $\mathrm{D}_{91 \mathrm{~b}}$ that includes solitary rugose corals, acrotetrid brachiopods, Neopanderodus, rare icriodids, and fenestrate bryozoans. The 
last solid nodular limestone of the member yielded a single Mimagoniatites tabuliformis Group, Oligophyllum sp., phacopids, and just one Icriodus in more than $2.5 \mathrm{~kg}$ of dissolved limestone. The brachiopod-rich main part of the neritic Brachiopod Marl Member (Beds $E_{1}-E_{3}$ ) is too argillaceous for conodont sampling. Above, the nodular Bed $\mathrm{E}_{4}$ with its abundant "Latanarcestes" and Lamellorthoceras documents a return to hemipelagic deposition, which correlates with the peak of the Daleje Transgression still low in the upper Emsian (LD IV-B of the ammonoid succession). The sudden goniatite incursion is not associated with a re-appearance of conodonts; Sample E4 was barren. The overlying Sellanarcestes Limestone Member has locally not yet been sampled for conodonts.

The succession at Rich Tamelougou (sheet Fask, NH-29-III-3, conodonts in Table 4 and Fig. 27) is more condensed but very similar to Bou Tserfine, with about the same number of cycles in the Hollardops Limestone Member despite reduced sedimentation (Brett et al. 2012). The sections described by Jansen et al. (2004b, 2007) and Becker et al. (2004b) lie very close to each other along strike on the same ridge. The top of the Rich 2 Sandstone includes cross-bedded and iron-rich calcareous sandstones, which indicate a very shallow deposition, mostly by tempestites. The upper boundary to the $9 \mathrm{~m}$ thick, rather unfossiliferous Akhal Tergoua Member is locally sharp. This suggests a drowning unconformity at the base of a transgressive system tract (TST). A sample from the first dark bluish-grey limestone produced a rather diverse conodont assemblage (10 taxa) with a slight dominance of Caudicriodus (47.2\%) over Latericriodus (34\%), and with 13.2\% Belodella, 3.8\% Neopanderodus (Fig. 27N), and a single, broken polygnathid. Despite the hypoxic and calm lithofacies, the conodonts are typical for a shallow marine setting. Conodonts reported by Jansen et al. (2004b, 2007: Fauna C10) from the basal $30 \mathrm{~cm}$ of the Oui-n-Mesdoûr Formation of section Torkoz IIa have a similar composition but Belodella and Neopanderodus were not listed. The same authors describe a different fauna with Latericriodus, Criteriognathus and very rare polygnathids from the upper part of the Akhal Tergoua Member (Fauna C13), which becomes increasingly marly upsection. A thin, Fe-rich red layer indicates a peak of oxygene deficiency at the top, followed by light grey marls with some limestone concretions. This better oxygenated interval correlates with the light-grey Unit C of Bou Tserfine and with the onset of the Rich 3 Sandstone of the eastern Dra Valley.

Weathering of the Hollardops Limestone Member forms distinctive, rounded hills separate from the main, southern slope of the Rich Tamelougou. From the distance, these hills look like a long series of dumps from excavations. The basal nodular beds are very argillaceous; samples were taken from the base, Bed 3 and Bed 9. Their icriodid faunas with some belodellids and panderodids are very sparse. The main, more solid and trilobite-rich limestones commence with Bed 19 (barren sample). A sample from the middle of the member taken in 2003 contained a diverse assemblage with ca $35 \%$ Caudicriodus (mostly Caud. ultimus Weddige, 1985 in Requadt \& Weddige 1985), 28\% Icriodus s. str., ca 5.5\% Latericriodus, $29 \%$ Belodella (Fig. 27Q) and a few Neopanderodus (Fig. 27O); no polygnathids or "ozarkodinids" were found. Fauna C14 from Torkoz of Jansen et al. (2004b, 2007) is rather similar. But such faunas are an exception; normally (e.g., Bed 35) there are very few conodonts in normal-sized samples and single cone genera (Neopanderodus) are rather dominant. Higher up in the member (Beds 61 and 105), Caud. ultimus remains as the only icriodid in association with Belodella and Neopanderodus.

The Brachiopod Marl Member is very inconspicuous at Rich Tamelougou. A change from trilobite limestones to nodular levels with "Latanarcestes" was recognized by Brett et al. (2012) in Bed 153. Dissolved "Latanarcestes" specimens yielded only a single Caudicriodus. Samples from Bed 161 and $1 \mathrm{~m}$ above continue the sparse assemblage of the upper Hollardops Limestone and are not diagnostic. As at Bou Tserfine, the pelagic faunal influx is not mirrorred in the composition of the conodont faunas.

The Sellanarcestes Limestone Member is locally very rich in anarcestids (three genera), trilobites, solitary rugose corals, nautiloids, crinoid ossicles, bivalves (Panenka), gastropods, and placoderms. A conodont sample taken from just above the first (loose) Sellanarcestes was almost barren (two small single cones). The complete lack of polygnathids and icriodids in goniatite limestones does not fit the expectations from current conodont biofacies models.

\section{Goniatite samples (Figs 28, 29; Table 5)}

In order to improve the regional ammonoid-conodont correlation, goniatites from additional localities and levels have been dissolved. These are in stratigraphic order from old to young (see Table 5):

RT-Erb: Loose block with Erbenoceras sp. from the syncline W of Rich Tamelougou, SW of Torkoz (sheet Fask, NH-29-III-3), illustrated in Becker et al. (2008).

OCh-Anet: Block with the negative imprint of an Anetoceras cf. obliquecostatum Ruan \& He, 1974 from the lower part of the Anetoceras Limestone of Ouidane Chebbi (see section log in Belka et al. 1999 and Klug 2001), sheet Hassi Beraber (NH-30-XXI-1).

BT-Kl: Several fragments of Klugites gesinae (Klug, 2001) gen. nov., sampled in situ from a nodular interval $c a$ 
in the middle of the Anetoceras Limestone at Bou Tchrafine NW (sheet 1:50,000 Arfoud, $\mathrm{x}=616.2, \mathrm{y}=88.6$ ).

Ouf-Sell: Several specimens of Sellanarcestes, collected in situ from the Sellanarcestes Limestone at Oufrane-West (Bed 11 of Ebbighausen et al. 2011; sheet Tata, NH-29-XI-3).

EKs-B: Several specimens of Sellanarcestes and Anarcestes, collected at Erg Kseir ( $c$ a $6.5 \mathrm{~km}$ E of Hassi Nebech) in situ from the $2^{\text {nd }}$ bed (Bed B) of the locally very goniatite-rich lower Anarcestes Limestone.

HN-TA29: Several specimens of Sellanarcestes and Anarcestes collected loose from the lower Anarcestes Limestone at Hassi Nebech (sheet Taouz-Est, NH-30-XV-3, near Bed 29).

EKs-D: Several specimens of Sellanarcestes and Anarcestes, collected at Erg Kseir in situ from the $4^{\text {th }}$ bed (Bed D) of the locally very goniatite-rich Anarcestes Limestone, which contains rare specimens of Achguigites tafilaltensis.

OCh-An: Several specimens of Anarcestes, collected loose from the Anarcestes Limestone at Ouidane Chebbi.

\section{Emsian conodont zonations (Fig. 30)}

\section{Previous Emsian conodont zonations}

There are previous approaches to distinguish Lower Devonian biozones based on different, co-occuring conodont groups (e.g., Mashkova 1979). Their correlation offers the best regional time resolution but separate polygnathid and icriodid zonations can be used internationally, too.

Polygnathids. - Based on faunas from Nevada, Klapper \& Johnson (1975) established the fundaments of the lower Emsian polygnathid succession, which combines the first appearances of species of two phylogenetic branches. Original zonal markers were Po. dehiscens s.l., which then included both Eol. excavatus and Eoct. lenzi (Klapper, 1969), Po. gronbergi, Po. nothoperbonus Mawson, 1987, Po. inversus, and Po. laticostatus (e.g., Klapper 1977, Weddige \& Ziegler 1977, Yolkin \& Izokh 1988). Yolkin et al. (1994) added at the assumed base of the Emsian a new kitabicus Zone and introduced an exvacatus Zone, which was subdivided into three subzones based on the first entries of Po. excavatus excavatus, Po. excavatus gronbergi, and Po. perbonus (Philip, 1966). Their Lower excavatus Zone replaced the controversial dehiscens (s.l.) Zone. According to Carls et al. (2002, 2009), the Middle excavatus Zone of the Zinzilban section begins in fact with the level of Eol. excavatus Morphotype 114, not with the entry of Eol. gronbergi.

Yolkin et al. (1994) did not accept the laticostatus Zone, which was partly justified by the re-identification of a morphologically transitional specimen between Eol. gronbergi and Eol. laticostatus figured by Klapper \& Johnson (1975, pl. 1, figs 25, 26). This specimen comes from a level below Eol. nothoperbonus but it is more similar to Eol. gilberti (Bardashev, 1986) than to typical laticostatus (see synonymy list in Bardashev et al. 2002). Mawson (1995) criticized the kitabicus, excavatus and nothoperbonus zones but defended the laticostatus Zone. The distinction of perbonus and nothoperbonus zones/subzones was doubted because their defining species enter almost at the same level in Victoria (Mawson 1987a). The separation of successive inversus and laticostatus zones is obviously restricted to some regions whilst in others $L$. inversus and Eol. laticostatus, which belong to separate phylogenetic lineages, enter together in the laticostatus Zone (e.g., Klapper et al. 1978, Bardashev \& Ziegler 1992). Such a pattern may reflect regionally delayed first occurrences of L. inversus.

Bultynck (1989) did not separate gronbergi and nothoperbonus zones at the base of the La Grange Limestone of the Armorican Massif. He used the entry of Po. catharinae to define an Upper gronbergi Zone. At La Grange, there is only a short interval for a nothoperbonus Zone/Subzone below the Upper gronbergi Zone. More recently, Martínez-Pérez et al. (2011) recognized an Upper nothoperbonus Zone based on the entry of Po. mashkovae Bardashev, 1986. However, they synonymized Po. catharinae with Po. mashkovae, which is not followed here. As emphasized in the original distinction of Bultynck (1989), the holotype of Eol. mashkovae is characterized by a deeper and rimmed basal cavity, followed posteriorly, due to strong cavity inversion, by a very distinctive carina whilst in Eol. catharinae only the posterior tip is inverted. It seems that the Upper nothoperbonus and Upper gronbergi zones represent more or less identical intervals. In order to allow an easier understanding, the latter is re-named here after its marker species as catharinae Subzone.

Baranov et al. (2014) established a different regional zonation for NE Siberia, which is characterized by several endemic species and, therefore, difficult to compare. This applies especially for their tripartite ivanovskyii Zone, with a gronbergi Subzone at the base (without typical Eol. gronbergi but with Eol. perbonus), sandwiched between excavatus and nothoperbonus zones. For the upper Emsian polygnathids, Weddige (1977) introduced the serotinus and costatus patulus zones, the latter with two informal divisions. Klapper et al. (1978) proposed in Bohemia a subdivision of the serotinus Zone, based on the entry 
of Po. cooperi cooperi Klapper, 1971, and recognized the Upper patulus Zone (now partitus Zone), which subsequently defined the Emsian-Eifelian boundary. Vodrážková et al. (2011) granted Po. patulus and Po. partitus full species status.

The alternative polygnathid zonations of Bardashev et al. (2002), based on supposed parallel polygnathid lineages, are not used here.

Icriodids. - Wittekindt (1966) established an I. corniger Zone, which included strata that now fall in the upper Emsian to lower Eifelian. Subsequently, Carls \& Gandl (1969) investigated the Lower Devonian succession of the eastern Iberian Chains (Celtiberia, NE Spain), which is rich in icriodids. They recognized in the lower Emsian an assemblage with two subspecies of Lat. bilatericrescens and others and in the upper Emsian a fauna with I. fusiformis and I. aff. corniger Wittekindt, 1966 (now I. corniger ancestralis), followed higher by the fauna with typical I. corniger. The distinction of the I. fusiformis fauna was subsequently recognized by Ziegler (1971, level of oldest "nonlatericrescide" icriodids) and Carls et al. (1972). The succession of the Sierra de Guadarrama of central Spain yielded Bultynck (1976) a more detailed Emsian icriodid sequence: Fauna IV with Caud. celtibericus, Fauna V with Caud. sigmoidalis, Fauna VI with Lat. bilatericrescens, Fauna VII with I. fusiformis, I. aff. corniger, I. rectirostratus, and Caud.? culicellus, and Fauna VIII with I. aff. fusiformis, I. corniger and others. Klapper et al. (1978) added data from Bohemia, which suggest that subspecies of Lat. beckmanni can be used as markers in the higher part of the lower Emsian. Further support comes from data in Bultynck (1989), who also specified the lower Emsian range of Lat. latus in the Armorican Massif.

The Celtiberian conodont succession was reviewed by Carls (1999) and Carls \& Valenzuela-Ríos (2002) and summarized in "conodont steps", which can be used as regional zones, but with high international correlation potential (e.g., Jansen et al. 2007, Becker \& Aboussalam 2011). Caudicriodus curvicauda seems to straddle the Pragian/Emsian boundary of current GSSP definition and is abundant in the "basal Emsian" Step 16 of Celtiberia (level of the oldest Eol. excavatus in supposedly equivalent strata of the GSSP, at $92 \mathrm{~m}$ ). Caudicriodus celtibericus and Caud. sigmoidalis enter in Step 17, together with Eol. excavatus Morphotype 114. A succession of both index icriodids, as in Faunas IV and V of Bultynck (1976), was not observed but forerunners of Lat. bilatericrescens were noted. Step 18 is defined by the entry of Lat. bilatericrescens gracilis Bultynck, 1985, which Carls \& Valenzuela-Ríos (2002) regarded as a distinctive species. Lat. bilatericrescens bilatericrescens and Lat. bilatericrescens multicostatus enter slightly higher and give Step 19. Step 20 is defined by the entry of Lat. latus and also includes Eol. gronbergi, and, slightly higher, Eol. catharinae. There is no icriodid innovation in Step 21. Caudicriodus culicellus is used to define Step 21, followed slightly later by I. fusiformis. The scheme does not extend to the higher part of the upper Emsian.

Similar successions from the Cantabrian Mountains were used by García-López \& Sanz-López (2002) to establish regional celtibericus, bilatericrescens, culicellus, corniger ancestralis, and corniger corniger zones. Alleged Caud. culicellus from the lower Emsian, from levels before and together with Crit. steinhornensis, are probably based on mixing the species with Caud. ultimus (as in García-López \& Alonso-Menendez 1994, pl. 2, figs 5-7). Slavík (2004) explored the potential of Lat. bilatericrescens gracilis as a basal Emsian index species and zonal marker in Bohemia. He confirmed that it enters slightly lower than the other subspecies, near an important event interval with the last Neomonograptus faunas.

The European icriodid succession cannot be easily transferred to different continents (see Klapper \& Johnson 1980, Bultynck 2003). Some taxa range into Asian regions, which partly belonged to Gondwana and partly formed distinctive crustal blocks. For example, Bardashev \& Ziegler (1992) noted four European species in Tadzhikistan and a few were variably noted in different regions of China. Such occurrences are given below in the correlation of the individual zones. But the rarity of icriodids in the lower Emsian of SE Asia is remarkable. It is especially strange that there are practically no icriodid faunas from the Emsian of Australia (e.g., Philip 1966; Mawson et al. 1985, 1987a; Mawson \& Talent 1989; Furey-Greig 1995; Sloan et al. 1995) since European Pragian and Middle Devonian icriodid species are wide spread on that continent (e.g., Mawson \& Talent 1994, Dongal 1995). In North America, especially in Nevada (e.g., Johnson et al. 1980, Johnson \& Klapper 1981), there are different lower Emsian taxa. They are followed by a widespread, endemic fauna with Lat. latericrescens robustus (Orr, 1971), whose base is commonly correlated with the serotinus Zone (e.g., Weddige \& Ziegler 1977, Klapper \& Johnson 1980). Baranov (2012) summarized the very different Lower Devonian icriodid zonation of Russian arctic regions, which is based on the evolution of Gagievodus and Vjaloviodus. But there are a few subordinate European taxa (e.g., Caud. sigmoidalis) and more of these can be found in the Russian Far East (see Eikhvald 2008, Baranov et al. 2014). Typical Arctic Russian taxa, such as Vj. taimyricus (Kuz'min, 1967), range from the Taimyr and Omolon regions (NE Russia; e.g., Sobolev et al. 1988) into Alaska (Lane \& Ormiston 1979) and western Yukon (Savage et al. 1985). The Salair region of South Siberia is characterized by yet a different lower Emsian icriodid lineage (Caud. amplus - vicinus - longicavatus; Izokh 1990, 1998), which partly extends into the Tuva region to the east (Izokh 2005). The Altai region to the south hosted the endemic Lat. altaicus (Aksenova, 
Table 5. Conodont record from dissolved Emsian goniatites of the Anti-Atlas. For explanation of sample numbers see text. Abbreviations: Bl. Marl = Black Marl Member, Sell. Lst. = Sellanarcestes Limestone, bilat. Ez. = local bilatericrescens bilatericrescens Ecozone. Entry of index taxa marked in bold.

\begin{tabular}{|c|c|c|c|c|c|c|c|c|}
\hline \multirow[t]{2}{*}{ Conodont zones } & & \multicolumn{2}{|c|}{ steinhornensis } & & & & cooperi & patulus \\
\hline & bilat. Ez. & \multicolumn{2}{|c|}{ latus [beckmanni] } & fusiformis & \multicolumn{4}{|c|}{ corniger corniger } \\
\hline Lithostratigraphy & Bl. Marl & \multicolumn{2}{|c|}{ Anetoceras Lst. } & Sell. Lst. & \multicolumn{4}{|c|}{ Anarcestes Limestone } \\
\hline Bed or sample No. & RT-Erb & OCh-Anet & BT-Kl & Ouf-Sell & EKs-B & EKs-D & HN-TA29 & Och- $A n$ \\
\hline Lat. bilat. bilatericrescens & 24 & 4 & 1 & & & & & \\
\hline Bel. resima & & 22 & & 3 & 9 & 11 & 2 & \\
\hline Bel. triangularis & & 3 & 1 & & & & & \\
\hline Crit. miae & & 2 & 5 & & & & & \\
\hline Crit. steinhornensis & & 29 & 28 & & & & & \\
\hline Caud. sigmoidalis & & 2 & & & & & & \\
\hline Lat. bilatericrescens (towards beckmanni) & & 9 & & & & & & \\
\hline Lat. beckmanni beckmanni & & 1 & 4 & & & & & \\
\hline Caud. celtibericus & & & 3 & & & & & \\
\hline Neop. perlineatus & & & & 8 & 10 & 19 & 7 & 2 \\
\hline Caud. culicellus culicellus & & & & 2 & 4 & 5 & 2 & \\
\hline L. aff. cooperi & & & & & & & 2 & \\
\hline Po. patulus & & & & & & & & 1 \\
\hline (Sub)species diversity & 1 & 7 & 6 & 3 & 3 & 3 & 4 & 2 \\
\hline Total conodonts & 24 & 72 & 41 & 13 & 23 & 35 & 13 & 3 \\
\hline
\end{tabular}

1987). An alleged I. trojani Johnson \& Klapper, 1981 from the lower Emsian of Yunnan (Jin et al. 2005) is not very similar to that endemic form of Nevada but closer to the $\mathrm{Si}$ berian icriodids.

Spathognathodids. - In the lower Emsian, Bultynck (1976) noted the significance of Crit. miae as an alternative index species for his Fauna V with Caud. sigmoidalis, followed above the first Eol. gronbergi by Crit. steinhornensis (Bultynck et al. 1979). This was subsequently confirmed in the Armorican Massif (Bultynck 1989), where Crit. steinhornensis enters as a marker species in the Upper gronbergi Zone, slightly above the entry of Eol. catharinae. The same range defines conodont Step 21 in Celtiberia (Carls \& Valenzuela-Ríos 2002). Both Crit. miae and Crit. steinhornensis had a very wide pantropical distribution (Klapper \& Johnson 1980) but the first has a longer range than observed by Bultynck (1976), down into the Pragian (see details below). In the upper Emsian no ozarkodinid zone has been proposed so far. However, Klapper et al. (1978) and Klapper \& Johnson (1980) noted that Oz. carinthiaca is a good index for the serotinus to patulus zones in Bohemia and several other regions.

\section{Regional Anti-Atlas polygnathid zonation}

The Emsian polygnathid record of the Anti-Atlas is partly very sparse and episodic, despite a predominant outer shelf setting, as indicated by frequent to very abundant dacryo- conarids and ammonoids. The peculiar regional aspects of Emsian conodont biofacies have first been outlined by Bultynck (1998). Rich polygnathid assemblages are confined in the Tafilalt and Maider to specific deepening phases. The complete regional ranges of all conodont taxa are summarized in Fig. 31.

Pragian. - The "Pragian Marls and Shales" (Unit D) and "Pragian Limestone" (Unit E) of the Tafilalt and corresponding strata of the Dra Valley (near the base of the Merzâ-Akhsai Formation, Faunas C6-9 of Jansen et al. 2007) almost lack polygnathids. This prevents a regional recognition of the kitabicus Zone. Eoct. pireneae (Boersma, 1974) has recently been found together with Caud. celtibericus in an allochthonous upper Pragian clast at the northern margin of the Anti-Atlas (Rytina et al. 2013). A single fragmentary specimen of the pireneae Group was found together with Lat. steinachensis in Sample BTN P/E2 at Bou Tchrafine North (Fig. 18V-X). It shows some similarities with specimens assigned to Morphotype $\alpha$ of Eoct. savagei Bardashev, Weddige \& Ziegler, 2002, which is a taxon that requires further investigation. Even more similar is the figured paratype of Eoct. ivanowskyii (Baranov, Slavík \& Blodgett, 2014). With respect to the limited knowledge of variability within the pireneae Group we do not wish to specify the species identification of our form. Both records of the group are so far the very limited evidence for a regional, long-ranging pireneae Zone in the Pragian of the Anti-Atlas (see further discussion of Valenzuela-Ríos 1997). 
(Regional) Eolinguipolygnathus excavatus Morphotype 114 Zone. - The oldest rich Tafilalt polygnathid assemblages can be morphologically diverse. The index form enters in the basal part of the Deiroceras Limestone at El Khraouia (Bed 15a, Fig. 20I, J) and it is associated at Jebel Ihrs (Bed 16a, Fig. 5N-Q) with typical excavatus morphotypes (Figs 5L, M, 6K, L), Morphotype beta sensu Bardashev et al. (2002; Fig. 5J, K), rare Eol. pannonicus Mashkova \& Apekina, 1980 (Fig. 6G, H), a few transitional forms towards Eocostapolygnathus, here named Morphotype JI16a (Fig. 6C, D; possibly the contemporaneous kitabicus in Belka et al. 1999), and early morphotypes of Eol. radula sp. nov. The latter are slightly transitional towards Eol. excavatus (Fig. 6A, B, I, J) and include forms with very wide basal cavity (Fig. 6E, F).

Eolinguipolygnathus excavatus s. str. was illustrated by Bultynck \& Hollard (1980) as Po. dehiscens from a slightly higher level in the same unit (Sample BTN BK 496); it provided the oldest evidence for their Fauna Ia. Belka et al. (1999) illustrated a supposed Po. gronbergi from their $2^{\text {nd }}$ sample of the Deiroceras Limestone of Ouidane Chebbi, Section I. This specimen, however, is a transitional form between excavatus and gronbergi (see Klapper \& Johnson 1975). Eolinguipolygnathus excavatus Morphotype 114 occurs throughout the middle and upper Deiroceras Limestone, based on samples from Hassi Nebech (Sample 6), Jebel Ihrs (Beds 16c, d, Fig. 7C, D, G, H, N, O), and El Khraouia (Bed 15f, Fig. 21D-F). Typical morphotypes of the species are associated (Fig. 7E, F). At Jebel Ihrs and El Khraouia, typical Eol. radula sp. nov. (Figs 6M-R, 21C) are diagnostic for the upper part of the zone. This new form does not occur at Bou Tchrafine West (Sample BTW1), which, however, has Eol. excavatus s. str. (Fig. 15A-D, G). There are rare Eol. excavatus, which show a trend towards Eol. perbonus (Fig. 7P, Q) but an inversion of the posterior basal cavity has not been observed in any specimen. The top of the Deiroceras Limestone is polygnathid-free at Ouidane Chebbi (Sample 22 of Belka et al. 1999), Jebel el-Mrier (Bed 26e), and in the SW Maider (Samples 3-5 from Ou Driss, Bultynck 1985).

Jansen et al. (2007) described from the poorly known section Sidi Rezzoug I in the eastern Dra Valley a Fauna C11 with Eol. excavatus, Caud. celtibericus, and Caud. sigmoidalis, which resembles faunas from the lower Deiroceras Limestone but it could be slightly older (conodont Step 17). Just slightly higher at Sidi Rezzoug, there is an icriodid assemblage that is typical for the middle Deiroceras Limestone (Fauna C12, see below).
The oldest polygnathids of the Tafilalt co-occur with icriodids of the upper part of Step 18 sensu Carls \& Valenzuela-Ríos (2002; see below). In the Zinzilban (Uzbekistan) lower Emsian, Eol. excavatus Morphotype 114 enters earlier, at the base of conodont Step 17, Eol. excavatus s. str. even earlier, at the base of Step 16. The same succession was used by Sanz-López (2002) to recognize in the eastern Pyrenees the Lower and Middle excavatus zones sensu Yolkin et al. (1994), which is supported by the recent data from the Central Pyrenees (Martínez-Pérez \& Valenzuela-Ríos 2014). Baranov et al. (2014) distinguished in NE Siberia an excavatus/sobolevi Zone. Since no Eol. excavatus Morphotype 114 has been figured, the base of this regional interval should be correlated with conodont Step 16.

It is assumed that sampling (Devonobactrites Shale) and biofacies (polygnathid-free "Pragian Limestone") aspects caused a regional delay of the first occurrence of both excavatus morphotypes. Eolinguipolygnathus pannonicus overlaps in the Kitab Reserve of Uzbekistan with the oldest Eol. excavatus but has not been reported from the levels of Morphotype 114 (Middle excavatus Zone sensu Yolkin et al. 1994). However, Martínez-Pérez \& Valenzuela-Ríos (2014) noted such an overlap from the Pyrenees.

[Regional Eol. excavatus-catharinae Interregnum]. - The Metabactrites-Erbenoceras Shale furnished so far no conodonts, which creates a regional polygnathid interregnum between the last rich fauna with Eol. excavatus and the oldest Eol. catharinae. There is also no conodont record from the corresponding shaly middle part of the Bou Tiskaouine Formation of the Maider. The limestones at the top of the Rich 2 Sandstone Member of the Dra Valley yielded icriodids but no polygnathids.

So far there are no polygnathids from the very base of the Anetoceras Limestone (e.g., at Jebel Ihrs, Bou Tchrafine West, and Ouidane Chebbi, Samples 25, 26 of Belka et al. 1999), which could narrow the interregnum. The Eol. gronbergi record plotted in Bultynck \& Walliser (2000a) with Sample BTW1b refers in fact to specimens from Sample BTW2 (see Bultynck \& Hollard 1980, p. 26).

It is likely that the gronbergi Subzone time interval begins in the conodont-barren Metabactrites-Erbenoceras Shale. This idea is supported by the presence of transitional forms between Eol. excavatus and both Eol. gronbergi and Eol. perbonus in the upper Deiroceras Limestone (as noted above). The Anti-Atlas faunas have no record of a nothoperbonus (Sub)Zone below the level of the first Eol. catharinae.

Figure 4. Lithological succession and the position of conodont samples, sea level changes, and named events at Jebel Ihrs (western Tafilalt). Abbreviations: $\mathrm{T}=$ transgression, $\mathrm{R}=$ regression, $\mathrm{ChE}=$ Chebbi Event, $\mathrm{UZE}=$ Upper Zlíchov Event, DE $=$ Daleje Event. For conodont ranges and zonation see Table 1. 

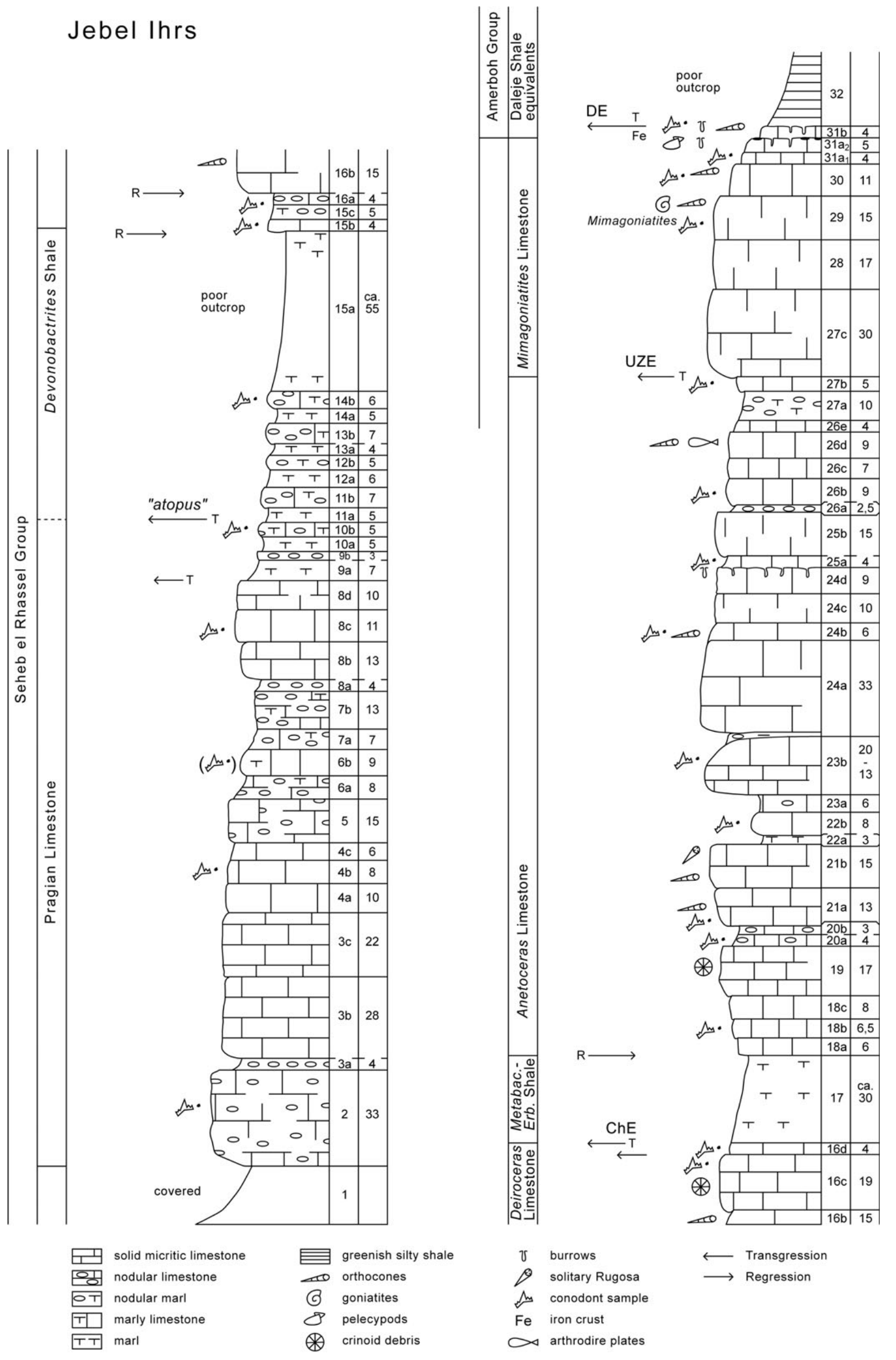
Eolinguipolygnathus catharinae Subzone. - The index species enters at Bou Tchrafine West (Sample BTW2, Fig. 15N, O, S), Bou Tchrafine North (Sample BTN4), and Jebel Ihrs (Bed 22b, Fig. 9B, C, Table 1) in the lower part of the Anetoceras Limestone. Since it is rare, and in accord with Bultynck (1989), its entry is only recognized as the base of a subzone of the gronbergi Zone. Eolinguipolygnathus aff. gronbergi co-occurs in both Bou Tchrafine sections (Fig. 15H-J). Sample BTW2 yielded also some Eol. nothoperbonus (Fig. 15E, F), but by comparison with the La Grange polygnathid succession (Bultynck 1989), the underlying polygnathid-barren interval of the AntiAtlas caused a regionally delayed entry of the latter taxon. The lower part of Bed 21a of Jebel Ihrs contains rare Eol. juferevi (Aksenova, 1987; Fig. 8L, M). As noted by Bardashev et al. (2002, synonymy list), a contemporaneous specimen, illustrated by Bultynck (1985, pl. 5, fig. 16) as Po. gronbergi from the basal upper Bou Tiskaouine Formation of Ou Driss (SW Maider, Sample OD6), also shows the platform outline of Eol. juferevi. Its precise range has not yet been established in the Russian type-region. Bultynck (1985) recorded associated Po. aff. perbonus (=Eol. nothoperbonus) and Crit. steinhornensis from Ou Driss. The latter species gives a correlation with a level above the first Eol. catharinae of the Tafilalt. The limestones overlying the Merzâ-Akhsai Formation of the Dra Valley yielded no polygnathids, with the exception of the possibly older Fauna C11 of Jansen et al. (2007), as discussed above. In the western Dra Valley there is a fragmentary Eol. excavatus M114 (Fig. 27L) from the basal Akhal Tergoua Member of Rich Tamelougou. Its correlation with the catharinae Subzone is based on the associated marker icriodids.

In the Tafilalt Eol. catharinae and polygnathids disappear in general in the middle Anetoceras Limestone, with the exception of rare last Eol. aff. gronbergi at Bou Tchrafine West (Sample BTW2b).

The catharinae Subzone correlates with the Upper gronbergi Zone of Bultynck (1989), the upper part of conodont Step 20 of Carls \& Valenzuela-Ríos (2002), and the Upper nothoperbonus Zone of Martínez-Pérez et al. (2011). In the Kitab Reserve of Uzbekistan, Eol. catharinae enters delayed, jointly with $L$. inversus (Yolkin et al. 2008). This interpretation is based on the La Grange Limestone, where L. inversus begins significantly higher than catharinae but overlaps it. Due to large faunal differences, it is difficult to correlate the catharinae Subzone with the polygnathid succession of NE Siberia (Baranov et al. 2014) but it may postdate most of the described faunas.

Linguipolygnathus inversus Zone. - Polygnathids are almost absent from the upper Anetoceras Limestone to main part of the Mimagoniatites Limestone. They are also lacking in the corresponding levels of the Maider and Dra Valley. There is just a single Eol. cf. gronbergi from the lower
Mimagoniatites Limestone of Jebel el-Mrier (Sample AL RTB8, Fig. 22F, G). The first thin-bedded, light grey limestone at the top of the Mimagoniatites Limestone yielded at Jebel Ihrs $\left(\right.$ Bed $\left.31 \mathrm{a}_{1}\right)$ a single, small and incomplete $L$. inversus (Fig. 9I, J). It resembles the small paratype of Klapper \& Johnson (1975, pl. 3, fig. 23). We do not follow the re-assignment of the latter in Bardashev et al. (2002) to Morphotype $\alpha$ of their Ctenopolygnathus senckenbergi, because this ignores ontogenetic changes in L. inversus and the very different morphology of the selected senckenbergi holotype (Po. inversus of Uyeno \& Klapper 1980, pl. 8-1, figs 9, 10). At Jebel Ihrs L. inversus is associated with dominant Eol. jacksoni (Fig. 9K-P), which could justify a different local zone name. There are also a probably new Linguipolygnathus species and a single L. annamariae (Bultynck, 1989), which also occurs in the inversus Zone of the Armorican Massif (Bultynck 1989). Jansen et al. (2007, fig. 3.15) figured a juvenile/questionable inversus specimen from the Oui-n-Mesdoûr Formation (Fauna C13) of the western Dra Valley. It co-occurs with Crit. miae, may represent a juvenile Eolinguipolygnathus and, therefore, an older level than the inversus Zone.

The very thin Tafilalt record of the inversus Zone (Jebel Ihrs) represents only the upper part of the zone, which is well known from Nevada, Canada, Germany (Schönau Limestone), and France (e.g., Klapper \& Johnson 1975, Bultynck 1989). Its global recognition is further based on a wide distribution in the Arctic regions of Eurasia (Baranov 2012), eastern Urals (Snigireva \& Nasedkina 1995), the Fergana Valley (Klishevich et al. 1985), Tadzhikistan (Bardashev \& Ziegler 1992), South China (e.g., Wang \& Ziegler 1983, Kuang \& Zhou 1992, Jin et al. 2005), Australia (e.g., Mawson et al. 1985), and the Russian Far East (Gagiev 2000).

Linguipolygnathus laticostatus Zone. - The laticostatus Zone is well developed at the top of Mimagoniatites Limestone of Jebel Ihrs (Bed 31b, Fig. 10C, D, G-L), El Khraouia (top Bed 22, Fig. 21K), and Bou Tchrafine (Fauna Va of Bultynck \& Hollard 1980, pl. II, figs 9-11; Bultynck \& Walliser 2000a; Samples BTW6, Fig. 15K, BTW5, and BTN BK494). There are two morphotypes of Eol. laticostatus (alpha and beta) and forms identified as Eol. cf. laticostatus (Sample BTW5, Fig. 15L, M, T, U). The laticostatus Zone is also developed at the top of the Bou Tiskaouine Formation of the SW Maider (Ou Driss, Bultynck 1985). Polygnathids are, however, absent from the top Mimagoniatites Limestone of the southern Tafilalt (Jebel Ouaoufilal, Jebel el-Mrier) and from the contemporaneous, more argillaceous strata of the Dra Valley. Eol. vigierei (Bultynck, 1989) is regionally an important associated marker (Figs 10E, F, 15P, Q) but not all specimens are typical (Fig. 21I, P, Q). This explains our cf. identifications. L. inversus is only associated at El Khraouia, but locally com- 
mon. Eol. gilberti is rare in the Anti-Atlas and only known from the latter locality (Fig. 21J), together with a form here identified as Eoc. cf. juferevi (Fig. $21 \mathrm{~N}, \mathrm{O})$.

The eastern Anti-Atlas laticostatus Zone correlates straight forward with the top lower Emsian laticostatus Zone of Alaska (Lane \& Ormiston 1979), British Columbia (Pyle et al. 2002), Nevada (Klapper \& Johnson 1975), Armorican Massif (NW France, Bultynck 1989), Montagne Noire (southern France, Feist et al. 1985), the Central Pyrenees (Martínez-Pérez et al. 2011), central Spain (Bultynck et al. 1979), Moroccan Meseta (Benfrika et al. 2007), the Rhenish Massif (e.g., Weddige \& Ziegler 1977), Harz Mountains (Germany, Luppold 1984), Bohemia (Klapper et al. 1978), Bulgaria (Boncheva 1991), eastern Urals (Snigireva \& Nasedkina 1995, Yurtische section), Uzbekistan (Yolkin et al. 1994, Mawson 1995), Tadzhikistan (Bardashev \& Ziegler 1992), Guangxi, South China (Ziegler \& Wang 1985), and Russian Far East (Gagiev 2000).

[Regional laticostatus-bultyncki Interregnum]. - There are no conodonts at all in the few marly limestone beds intercalated within the Daleje Shale Equivalents of the Tafilalt and no polygnathids in the correlative limestones of the Er Remlia Formation of the Maider or in the Hollardops Limestone Member and Brachiopod Marl Member (nodules with "Latanarcestes") of the western Dra Valley. In these three regions, the polygnathid gap between the Eol. laticostatus and $L$. bultyncki faunas forms regionally a distinctive, facies-controlled interregnum.

Linguipolygnathus bultyncki Zone and Subzone. - The index species enters in the Tafilalt in the lower Anarcestes Limestone of Hamar Laghdad South (Samples HLS II1-2, Figs 15V, 16A) but elsewhere it is uncommon or absent in the same unit (samples from Erg Kseir and El Khraouia). Belka et al. (1999) reported L. bultyncki at Ouidane Chebbi from Sample 37 from above Sell. neglectus (full goniatite record in Klug 2002), which is an index species of the An. simulans Zone (Ebbighausen et al. 2011). In the SW Maider (Ou Driss, Sample 12), the first L. bultyncki is from the top of the Er Remlia Formation and probably slightly older than the first Tafilalt specimens (Bultynck 1985). In the northern Maider it appears in the overlying lower Tazoulait Formation (Sample 4 of Ouahlane, Fauna VIb in Bultynck 1985), which correlates with the lower Anarcestes Limestone. The middle, Sellanarcestes bearing part of the Lower Member of the Timrhanrhart Formation of the eastern Dra Valley yielded the zonal index (identified as linguiformis Morphotype $\alpha$ ) at El Annsa (Sample 27-3) and Foum Timrhanrhart (Sample 25-1). These two records provided the original definition for Fauna VIb in Bultynck \& Hollard (1980) but may have come from above the solid Sellanarcestes Limestone, where Sellanarcestes and Anar- cestes co-occur (LD IV-D1). The Sellanarcestes Limestone itself has dominating Belodella (Fig. 29K) and Neopanderodus but no polygnathids in a new sample from Oufrane (Sample Ouf-Sell, Bed 11 of Ebbighausen et al. 2011) and no L. bultyncki at El Anhsour (Samples 16 and 19b). However, there are still some L. inversus (Fig. 25AB, AC) and L. aff. inversus (Fig. 25Z, AA), which apparently belong to the upper Emsian top of the extended laticostatus Zone. In the western Dra Valley, L. cf. bultyncki occurs rarely in the Sellanarcestes Limestone Member of the Khebchia Formation at Hassi Targa (Bultynck \& Hollard 1980).

As discussed by Bultynck (1985), the bultyncki Zone correlates with the lower part of the serotinus Zone of Bohemia, where the two zonal markers enter together (Klapper et al. 1978, Klapper \& Vodrážková 2013). This applies also to the Fergana Valley of central Asia (Kim et al. 1988), South China (Ziegler \& Wang 1985, Bai \& Bai 1988), and Queensland (Mawson \& Talent 1989). In Nevada (Johnson et al. 1980, table 15), British Columbia (Pyle et al. 2002), and New South Wales (Talent \& Mawson 1994), L. serotinus enters slightly before L. bultyncki. The "Tafilalt pattern", with L. bultyncki as the only polygnathid at the base of the serotinus Zone, was also observed in the Istanbul region (Saydam-Demiray \& Capkinoglu 2012). The general rarity of polygnathids in the pelagic basal upper Emsian of all of the Anti-Atlas, confirmed by our re-sampling of various goniatites, is striking. The strong biofacies influence caused a delayed regional entry of L. serotinus.

Linguipolygnathus cooperi cooperi Subzone. - The index species occurs in the Tafilalt together with L. bultyncki in higher parts of the Anarcestes Limestones of Hamar Laghdad (Samples HLS-6 to HLS-3, Fauna VIc of Bultynck \& Hollard 1980). Sample HLS II-4 proves that L. serotinus may enter at $c a$ the same level (Fig. 15W), which eliminates the distinction of a subsequent regional Fauna VII with L. serotinus. A loose Sellanarcestes-Anarcestes goniatite sample from Hassi Nebech yielded very narrow forms resembling to some extent the Australian L. pugiunculus (Mawson, 1997); they are here identified as L. aff. cooperi.

In the Maider the cooperi cooperi Subzone is present in the middle to higher parts of the Tazoulait Formation, where it partly overlaps Sellanarcestes. Records are from Ou Driss (Samples 13, 14 and 16), Ouahlane (Sample 6), and Tizi n'Ikouâch (Samples 5 and 7, Bultynck 1985, pl. 7, figs $5,6,14)$. L. cracens has only been found at Ou Driss (Sample 16, Bultynck 1985, pl. 7, fig. 1). L. serotinus enters slightly above $L$. cooperi cooperi at Ou Driss (Sample 30-5, Bultynck \& Hollard 1980, pl. II, figs 12, 13) and Tizi n'Ikouâch (Sample 7; Bultynck, 1985, pl. 5, fig. 7) in the lower El Otfal Formation. In the second locality, L. quadratus (Klapper, Ziegler \& Mashkova, 1978) or L. foliformis (Snigireva, 1975) were noted, too (Bultynck 
1985, pl. 6, figs 1, 2), but both are now regarded as serotinus synonyms (Klapper \& Vodrážková 2013).

An overlap of Sellanarcestes and L. cooperi cooperi was also reported from the lower part of the Timrhanrhart Formation of the eastern Dra Valley, based on a sample from El Annsa (Bultynck \& Hollard 1980, pl. II, fig. 18a, b). Linguipolygnathus serotinus (Telford, 1975) co-occurs with Anarcestes in Sample 25-3 at Foum Timrhanrhart. This record provided the original base for the regional Fauna VII (Bultynck \& Hollard 1980). Polygnathids are very rare in the Sellanarcestes Limestone Member of the Khebchia Formation of the western Dra Valley. Only section Hassi Targa yielded a single L. cf. bultyncki (Bultynck \& Hollard 1980). A new sample from the Rich Tamelougou hardly had any conodonts (Table 4).

The regional cooperi cooperi Subzone correlates with the higher part of the serotinus Zone of Bohemia (Klapper et al. 1978) and the Carnic Alps (e.g., Schönlaub 1985), the Upper serotinus Zone of South China (Ziegler \& Wang 1985), of the Istanbul region (Saydam-Demiray \& Capkinoglu 2012), eastern slope of the Urals (Snigireva \& Nasedkina 1995), Uzbekistan (Apekina \& Mashkova 1978, Kim et al. 1988), Tadzhikistan (Bardashev \& Ziegler 1992), and New South Wales (Talent \& Mawson 1994). Obviously it can also be recognized in peninsular Malaysia (record of Lane et al. 1979) and in the Armorican Massif (Lardeux \& Weyant 1993).

Polygnathus patulus Zone. - The index species dominates at Hamar Laghdad South (Sample HLS II-6) in the higher part of the Anarcestes Limestone. Linguipolygnathus cooperi, L. serotinus (Fig. 15X), and L. bultyncki are associated. Klug (2002) showed that the upper part of the Anarcestes Limestone at Jebel Ouaoufilal contains Po. patulus (Fig. 29A) together with L. serotinus. A new sample of anarcestids from Ouidane Chebbi yielded only a juvenile Po. patulus in association with two Neopanderodus.

Fauna VIII with Po. costatus patulus was originally based on Samples 22, 23 at Ou Driss from the Maider (Bultyck \& Hollard 1980). Bultynck (1985, pl. 8, fig. 1) lowered the local zonal base to Sample 19, less than $2 \mathrm{~m}$ above the base of the El Otfal Formation. Not much higher transitional forms towards lower Eifelian members of the Po. costatus Group were noted (Sample 20), also at Ouahlane and Tizi n'Ikouâch in the northern Maider. There are no conodonts from the corresponding clastics of the Dra Valley, both in the east (upper Timrhanrhart Formation) and the west (Bou Tserfine Member). But Po.patulus does occur in the basal Eifelian of the latter region (Bultynck \& Hollard 1980).

The Anti-Atlas patulus Zone can be correlated straight forward with the same Zone of Nevada (Johnson et al. 1985), the Rhenish Massif (e.g., Weddige 1977, Weddige \& Requadt 1985) and Harz Mountains of Germany
(Luppold 1984), Austria (Schönlaub 1985), Bohemia (Klapper et al. 1978), Bulgaria (Boncheva 1991), Yunnan (Carls \& Gong 1992), Guangxi (e.g., Wang \& Ziegler 1983, Bai \& Bai 1988), and eastern Australia (e.g., Mawson 1987b).

Lower Eifelian. - All top-Emsian polygnathids continue into the basal Eifelian Po. partitus Zone, which can be precisely located at Hamar Laghdad South (Sample HLS II-7) and in the Maider (Bultynck 1985). Associated polygnathids are Po. patulus, L. zieglerianus, and L. cooperi cooperi. L. bultyncki includes forms with well-rounded outer posterior margin (Fig. 16B, J), which defines Morphotype beta sensu Wang \& Ziegler (1983). Such forms are intermediate between forms named as Po. obovatus Xiong (in Xian et al. 1980) and Po. labiosus mawsonae Long \& Burrett, 1989, which Klapper \& Vodrážková (2013) treated as intraspecific variants of L. bultyncki. L. pinguis enters in the upper part of the partitus Zone (Sample HLS II-9) and includes an aberrant specimen (Fig. 16M).

The costatus Zone enters in Sample HLS II-11, based on the index species (Fig. 16N) and Po. angusticostatus (Fig. 16O, P). L. zieglerianus, L. bultyncki Morphotype beta (Fig. 16H, I), and L. pinguis (Fig. 16K, L) are associated. A comparable lower Eifelian polygnathid succession of the Tafilalt has recently been published by Becker \& Aboussalam (2013).

\section{Regional Anti-Atlas icriodid zonation (Fig. 30)}

Pragian. - A crinoidal limestone at Bou Tchrafine North (Samples BTN P/E1-2) and thin limestones within the "Pragian Marls and Shales" at El Khraouia (top Bed 8) yielded small or rich faunas with Lat. steinachensis Morphotypes eta (Fig. 17C) and beta (Fig. 20D). The first locality yielded a single and unique Latericriodus sp. nov. (Fig. 18S-U). The second locality also has some incomplete Lat. cf. claudiae (Figs 20B, C) and slender, early relatives of Caud. celtibericus (Fig. 20A). Bultynck \& Walliser (2000b) recorded from Achguig Caud. sp. ex gr. angustoides (Carls \& Gandl, 1969) from the local basal layer of the "Pragian Limestone". Lat. steinachensis is also known from the northern Maider, where it is associated with various Pelekysgnathus (Plodowski et al. 2000). Morphotype eta is in the Barrandian a lower/middle Pragian index species (sensu the type region, Slavík 2004b) that probably does not reach the level of the current (Zinzilban) basal Emsian GSSP (Slavík et al. 2007). A similar range applies to the central Pyrenees (Valenzuela-Ríos 2002), Carnic Alps (Schönlaub 1985, Suttner 2007, also with an upper overlap with celtibericus relatives), and Urals (Mavrinskaya \& Slavík 2013). Therefore, it is possible to recognize in the Tafilalt an undoubted Pragian Lat. steinachensis 
Zone (of any stage definition). It includes in the eastern Dra Valley Fauna C7 from the top of the Assa Formation (Jansen et al. 2007), which consists of Caud. steinachensis (no morphotype specified) and questionable Caud. angustoides castilianus (Carls, 1969). In the western Dra Valley, Fauna C8 from the base of the Merzâ-Akhsai Formation is similar but there are also the regionally oldest Caud. curvicauda (Jansen et al. 2007). Fauna C9 from $75 \mathrm{~cm}$ higher adds Lat. aff. beckmanni and the regionally youngest Wurmiella excavata (Branson \& Mehl, 1933). The co-occurrence of Lat. steinachensis with Pelekysgnathus serratus serratus (Fig. 16T, U) at Bou Tchrafine North (Sample BTN P/E1) gives a position in the short, early middle Pragian overlap interval of both taxa (see Al-Rawi 1977 for Franconia and the Carnic Alps record of Schönlaub 1985). The steinachensis Zone can be easily correlated around the globe, from the Moroccan Meseta (Benfrika et al. 2007) to western North America (e.g., Murphy \& Cebecioglu 1984), Franconia (Al-Rawi 1977), central Asia (Bardashev \& Ziegler 1992), and southern and eastern parts of Australia (Mawson \& Talent 1994).

Bed 9b (Sample MA RTB 2a) from the top of the "Pragian Marls and Shales" at El Khraouia contains only Caud. cf. curvicauda. It may represent a slightly younger level than the mentioned Dra Valley Fauna C9 with Lat. steinachensis and Caud. ?curvicauda. Typical curvicauda specimens range in the Barrandian into the classical upper Pragian, together with Caud. celtibericus (Slavík 2004b). The species occurs also in the higher Pragian of the Moroccan Meseta (Lazreq 1990). The Zinzilban GSSP level is tentatively projected to a position low in the main "Pragian Limestone" of the Tafilalt, which agrees with the regional dacryoconarid record. Bultynck \& Walliser (2000b) came to a similar conclusion. Such a correlation has a significant impact for trilobite stratigraphy, because there are many Pragian marker trilobites in the "Pragian Limestone" of the Tafilalt.

Caudicriodus celtibericus Zone. - The index species enters in the basal "Pragian Limestone" of El Khraouia (mostly small specimens, Bed 11a, Fig. 20H). It also occurs in the middle part of the unit at Jebel Ihrs (Bed $4 b$, rarely, Fig. 5C, D) and in the upper part at Hassi Nebech (Bed 22c, Sample TA RTB4, Fig. 22N) and Jebel Ihrs (Bed 13). Bel. resima (Philip, 1965), Bel. triangularis (Stauffer, 1940), P. unicostatus Branson \& Mehl, 1933 (record of Belka et al. 1999 from Ouidane Chebbi), and Pseud. beckmanni are associated shallow-water taxa and often more dominant. This led Becker \& Aboussalam (2011) to propose a Lower Belodella Ecozone for the "Pragian Limestone" at Jebel Ihrs. Caud. curvicauda, another icriodid of the Barrandian upper Pragian, was only found in the southern Tafilalt, where it excludes Caud. celtibericus (Jebel Ouaoufilal, top "Pragian Limestone"). But it co-occurs with Eoct. pireneae and Caud. celtibericus in an allochthonous block of the Tinerhir region (northernmost Anti-Atlas, Rytina et al. 2013). Bultynck \& Walliser (2000b) recorded from the "Pragian Limestone" of Achguig first transitional forms between Caud. curvicauda and celtibericus, followed by typical Caud. celtibericus. There are no contemporaneous conodonts from the Maider and Dra Valley.

The celtibericus Zone equals Fauna IV of Bultynck (1976) and the upper Pragian celtibericus Zone of the Barrandian (Kalvoda 1995, Slavík 2004b), if defined by the entry of the index species, not by the extinction of the Pelekysgnathus serratus Group. The latter ranged much higher in the Moroccan Meseta (Benfrika et al. 2007). In Celtiberia, Caud. celtibericus enters delayed, together with Caud. sigmoidalis and the oldest Eol. excavatus Morphotype 114 in conodont Step 17 (Carls \& Valenzuela-Ríos 2002). In the Moroccan Meseta, the celtibericus Zone can be recognized in the Oued Cherrat region (Benfrika \& Bultynck 2003) and Rabat-Tiflet Zone (Benfrika et al. 2007).

Lower Devonian icriodid faunas are generally characterized by a high level of endemism. Therefore, it is interesting that the celtibericus Zone can be recognized in the distant Amur region of the Russian Far East (Eikhvald 2008, regional level of I. huddlei Klapper \& Ziegler, 1967). Preliminary data (Valenzuela-Ríos in Senglaub \& Ebert 2002) also indicate a spread into eastern New York State.

At least the main/upper part of the polygnathid-free "Pragian Limestone" (celtibericus Zone) of the Tafilalt correlates with conodont Step 16 and with the basal Emsian in its current GSSP definition (see discussion in Kalvoda 1995). Most likely, it will not fall in a future Emsian defined by the entry of Eol. excavatus Morphotype 114.

[Regional celtibericus-gracilis Interregnum]. - There are no conodonts from the Devonobactrites Shale or from correlative beds of the Maider and Dra Valley. Therefore, it is regionally not possible to recognize conodont Step 17 of Carls \& Valenzuela-Ríos (2002), which is best characterized by the oldest Caud. sigmoidalis. Support for this correlation comes from the main range of the dacryoconarid Guerichina both in Step 17 of Celtiberia and in the lower part of the Devonobactrites Shale (Alberti 1980, 1981).

Lat. bilatericrescens gracilis Zone. - At Jebel Ihrs, the basal part of the Deiroceras Limestone (Bed 15b) still has a monospecific Caud. celtibericus assemblage but the same level is dominated at Bou Tchrafine West and North (Samples BTW0 and BTN1), Hassi Nebech (Sample TA 6), and El Khraouia (Bed 15a, Fig. 20L) by Caud. sigmoidalis. The zonal index Lat. bilatericrescens gracilis (Fig. 5G) and transitional forms towards multicostatus (Fig. 5H) enter as subordinate faunal elements at Jebel Ihrs in Bed 16a (there 
associated with Caud. sigmoidalis, Fig. 5F) and at El Khraouia in Bed 15a. Caudicriodus celtibericus may be associated (Sample BTW0, Fig. 16V-X, El Khraouia, Bed 15a, Fig. 20M) and include specimens, which are still somewhat transitional from Caud. curvicauda. The last good Caud. curvicauda were observed at El Khraouia in Bed 15c but elsewhere the species may range higher (into the Barrandian bilatericrescens Zone, see Kalvoda 1995). An unexpected range extension applies to Lat. steinachensis, which occurs in the Deiroceras Limestone of Bou Tchrafine North (Samples BTN1 and BTN2, Fig. 17E, as well as in the lateral Sample BK496, Fig. 17A). Normally this taxon disappears in the middle Pragian. The lower Emsian representatives are less curved than typical specimens and could be assigned to a new, late morphotype.

Caud. sigmoidalis is also dominant in the basal Bou Tiskaouine Formation of the Maider (Ou Driss, Samples 1-4, Bultynck 1985, pl. 5, figs 3, 4), which lead to the recognition of Fauna Ia (Bultynck \& Hollard 1980) in that unit.

The bilatericrescens gracilis Zone correlates probably only with the upper part of Fauna V of Bultynck (1976) with Caud. sigmoidalis. Based on rare morphotypes close to Lat. bilatericrescens multicostatus, it equals the transition from conodont Step 18 to 19 sensu Carls \& Valenzuela-Ríos (2002). Regionally, its base coincides with the base of the Eol. excavatus Morphotype 114 Zone. Slavík (2004a) emphasized the significance of the entry of Lat. bilatericrescens gracilis as an alternative basal Emsian marker. Sanz-López (2002) listed I. gracilis from a much lower level (kitabicus Zone) of the eastern Pyrenees, which cannot be evaluated since there are no illustrations of specimens. Benfrika \& Bultynck (2003) documented an earlier range of Lat. bilatericrescens gracilis than Lat. bilatericrescens bilatericrescens in the Al Attamna region of the Moroccan Meseta.

Latericriodus bilatericrescens bilatericrescens Zone. The zonal index enters in the upper half of the Deiroceras Limestone at Bou Tchrafine West (Sample BTW0-1) and North (Sample BTN BK496). At the top of the unit the nominate subspecies (El Khraouia, Bed 15f; Jebel Ihrs, Bed 16c, Fig. 7A, B) and Lat. bilatericrescens multicostatus (El Khraouia, Bed 15f, Fig. 20N-Q; Jebel Ihrs, Bed 16c, d, Fig. 7I, M), which is an alternative marker form, can be dominant. In Samples BTW1 (see Bultynck \& Hollard 1980, pl. I, figs 1, 2) and BTN 2-3 Caud. sigmoidalis is still the most common icriodid. Caudicriodus celtibericus (at Jebel Ihrs, El Khraouia, and Hassi Nebech) and Lat. bilatericrescens gracilis (Sample BTN 2-3 and Bed 15f at El Khraouia) continue from the previous zone. A Caud. cf. ultimus was recorded together with Lat. bilatericrescens bilatericrescens by Belka et al. (1999) from the upper Deiroceras Lime- stone of Ouidane Chebbi but not illustrated. The Jebel el-Mrier (Bed 26e, Sample AL RTB 6) in the southern Tafilalt has the most restricted icriodid fauna of the bilatericrescens Zone, with only Lat. bilatericrescens bilatericrescens (Fig. 22B) and Caud. sigmoidalis (Fig. 22A).

The bilatericrescens bilatericrescens Zone has not yet been recognized in the lower Bou Tiskaouine Formation of the Maider. Bultynck (1985) reported at Ou Driss Lat. bilatericrescens gracilis only from higher parts of that member (Samples 3-5, pl. 5, figs 1, 2), a level that correlates with the upper Deiroceras Limestone of the Tafilalt. The three subspecies of Lat. bilatericrescens continue in the Tafilalt into the basal Anetoceras Limestone (Jebel Ihrs, Bed 18b, Fig. 8A-C, and Ouidane Chebbi, Sample 25, Belka et al. 1999), locally accompanied by Caud. celtibericus (Jebel Ihrs).

Fauna II with Lat. bilatericrescens of Bultynck \& Hollard (1980) was based on the limestones above the Rich 2 Sandstone Member of the eastern Dra Valley (Mdâour-el-Kbîr Ravine, with early Erb. advolvens). In the western Dra Valley, specimens illustrated from the basal Oui-n-Mesdoûr Formation of Tjafane by Bultynck \& Hollard (1980, pl. I, figs 22-24) belong to Lat. bilatericrescens gracilis and include the holotype. An ontogenetic series from Oui-n-Mesdoûr (Bultynck \& Hollard 1980, pl. I, figs 15-19) falls in Lat. bilatericrescens multicostatus. Fauna C12 of Jansen et al. (2007) from Sidi Rezzoug I (eastern Dra Valley) with Lat. bilatericrescens bilatericrescens, Lat. bilatericrescens multicostatus, and Caud. celtibericus represents the same interval. Caud. sigmoidalis is still more frequent than the Lat. bilatericrescens Group at Tjafane (Sample 20-1, Bultynck \& Hollard 1980, pl. I, figs 5, 6). In terms of sequence stratigraphy, it is likely that the Dra Valley assemblages correlate partly with the Metabactrites-Erbenoceras Shale of the Tafilalt, as suggested by De Baets et al. (2010) and confirmed by the dacryoconarid record in Hollard (1978) and Alberti (1998).

The Moroccan bilatericrescens bilatericrescens Zone equals Fauna VI of Bultynck (1976) and conodont Step 19 of Carls \& Valenzuela-Ríos (2002). Its lower part correlates with the higher parts of the excavatus Morphotype 114 Zone. This is supported by rare Eol. excavatus in the lower Bou Tiskaouine Formation of the Maider. The bilatericrescens bilatericrescens Zone is obviously also recognizable in the Moroccan Meseta (Benfrika \& Bultynck 2003, Benfrika et al. 2007) and Bulgaria (data in Boncheva et al. 2007).

Latericriodus latus Zone. - The index species enters at the base of the Anetoceras Limestone at Bou Tchrafine West (Sample BTW1b, Figs 17K-M) and low in the same unit at Jebel Ihrs (Bed 20b, Fig. 8I). In both localities, as well as at 
Ouidane Chebbi (Sample 26 of Belka et al. 1999), it is accompanied by the oldest Lat. beckmanni beckmanni (e.g., Fig. 9A), which is an alternative zonal marker. Latericriodus bilatericrescens bilatericrescens is often the dominant icriodid (Jebel Ihrs, Bed 20b, Figs 8D, E, and Bed 22B; Sample BTW2; Sample BTN4, Fig. 17F, G, Sample OCh-Anet, Fig. 28G) and it may be associated with bilatericrescens multicostatus (Figs $8 \mathrm{~F}-\mathrm{H}, 22 \mathrm{C}$ ). Latericriodus bilatericrescens gracilis is generally rather rare and currently only known from Jebel Ihrs and Section BTN (Fig. 17H). Caudicriodus celtibericus, which is sometimes frequent (e.g., at Jebel el-Mrier, Sample AL RTB 7a), and Caud. sigmoidalis (Sample BTN4) continue as well. Latericriodus armoricanus appears slightly later than Lat. latus, still within the lower Anetoceras Limestone (Sample BTW2, Fig. 17N, O, Lat. aff. beckmanni of Bultynck \& Hollard 1980, pl. I, fig. 7; Jebel Ihrs, Bed 21a, Fig. 8J). This matches closely the La Grange Limestone (Bultynck, 1989). However, the first Lat. beckmanni sinuatus were found in the Tafilalt (Jebel Ihrs, Bed 22b, Fig. 8N) lower than in the Armorican Massif. They represent the globally earliest record of the subspecies.

Latericriodus latus disappears in the Tafilalt in the middle Anetoceras Limestone, which mostly contains Lat. bilatericrescens bilatericrescens (e.g., Fig. 28B). At this level, Lat. bilatericrescens gracilis occurs only in Sample BTN 31-1. Regionally, the last lower Emsian Lat. beckmanni beckmanni were observed in Samples Och-Anet (Fig. 28H), BT-Kl (Fig. 28C), and BTN 31-2, the last Lat. armoricanus in Sample BTW2b. Caudicriodus celtibericus is locally still present (Jebel Ihrs, Bed 25a; Sample BT-Kl, Fig. 28A) and reaches the upper Anetoceras Limestone (Jebel Ihrs, Bed 26b). Even higher, Lat. bilatericrescens is the only remaining icriodid in more and more sparse assemblages (e.g., Jebel Ihrs, Bed 27b, Fig. 9F), with a last record of bilatericrescens multicostatus from Jebel el-Mrier (Sample 7b).

Finally, there are almost no icriodids left in the Mimagoniatites Limestone. Increasing shallowing led both in the Tafilalt and Maider to a complete lack of conodonts or restriction to Belodella-Neopanderodus assemblages (Jebel Ihrs, Bou Tchrafine West, Jebel el-Mrier, Jebel Kfiroun, Ou Driss). Rare exceptions are a few Lat. bilatericrescens bilatericrescens from Bou Tchrafine West (Sample BTW4b) and the Jebel Issimour (Plodowski et al. 2000). As pointed out by Becker \& Aboussalam (2011), an Upper Belodella Ecozone developed in the eastern Anti-Atlas before the end of the lower Emsian.

The knowledge of terminal lower Emsian icriodids is generally very poor, not only in the Anti-Atlas, but also in Spain (García-López \& Sanz-López 2002, Garcia-López et al. 2002, Carls \& Valenzuela-Ríos 2002), in the Armorican Massif (Bultynck 1989), and Bohemia. The sudden re-appearance of rich polygnathid faunas at the top of the
Mimagoniatites Limestone is not paralleled by a revival of icriodids. They are lacking at Jebel Ihrs, Bou Tchrafine, Jebel el-Mrier, and Ou Driss. Only El Khraouia yielded two specimens of Caud. ultimus (Fig. 21L, M), which resemble to some extent Caud. celtibericus. The precise lower range of Caud. ultimus needs further elaboration.

In the eastern Dra Valley, the latus Zone cannot be recognized within bilatericrescens-celtibericus assemblages of the Lower Member of the Mdâouer-el-Kbîr Formation (e.g., at Mdâouer-el-Kbîr, Fig. 18). In the ca middle part of the Akhal Tergoua Member of the western Dra Valley succession (Bed A10b at Bou Tserfine), the alternative markers Lat. beckmanni beckmanni (Fig. 27A) and Lat. beckmanni sinuatus were found in association with Lat. bilatericrescens bilatericrescens, Caud. sigmoidalis (Fig. 27C) and Caud. cf. ultimus (Fig. 27B). A similar, diverse association, including Lat. beckmanni ?sinuatus (Fig. 27G), occurs at the base of the member south of Torkoz (Rich Tamelougou) and in Fauna C10 of Jansen et al. (2007). In the SW (Ou Driss, Bultynck 1985, Sample 8) and northern Maider (Jebel Issimour, Plodowski et al. 2000), as well as at the top of the Akhal Tergoua Member of the Oui-n-Mesdoûr Formation (western Dra Valley, Becker et al. 2008), Lat. bilatericrescens bilatericrescens is the only icriodid (Bou Tserfine, Sample A18) in the top lower Emsian. This gave the regional "bilatericrescens Ecozone" of Becker et al. (2008).

The entries of Lat. latus and Lat. beckmanni beckmanni coincide both in the Tafilalt and in Celtiberia and define conodont Step 20 of Carls \& Valenzuela-Ríos (2002). In the La Grange Limestone (Bultynck 1989), the latus Zone precedes slightly the first appearance of Eol. nothoperbonus. This enables us to project the base of the nothoperbonus (Sub)Zone into the basal Anetoceras Limestone. The latus Zone is further developed in Franconia (the type-region, Al-Rawi 1977) and in the Carnic Alps (Schönlaub 1985). The stratigraphic significance of the oldest Lat. beckmanni is clouded by alleged much earlier occurrences in Bohemia (e.g., Chlupáč \& Lukeš 1999). These were marked as questionable in Slavík (2004a) and their relationships with Lat. simulator (Carls, 1969) have to be clarified. In the Kitab Reserve area of Uzbekistan, Lat. beckmanni beckmanni was first observed slightly above the oldest Eol. nothoperbonus (Yolkin et al. 2008). In Tadzhikistan, Lat. beckmanni beckmanni is very rare and was found within the higher gronbergi Zone below the first Lat. latus (Bardashev \& Ziegler 1992). Locally, the latter reaches beds with $L$. inversus, which enables a projection of its upper range into the conodont-poor Mimagoniatites Limestone of the Tafilalt. Lat. beckmanni also enables a correlation into lower Emsian sections of the Moroccan Meseta (Benfrika et al. 2007), southern Siberia (Rudny Altai, Yolkin et al. 2005), and South China (Wang \& Ziegler 1983, Ziegler \& Wang 1985). 
Icriodus fusiformis Zone. - At the base of the upper Emsian, the icriodid record is interrupted in the Tafilalt to eastern Dra Valley by the Daleje Shale Equivalents and corresponding clastics of the lower Er Remlia Formation and Rich 3 Sandstone Member. The oldest fusiformis Zone, Fauna Vb of Bultynck \& Hollard (1980), was based on samples from the Hollardops Limestone Member of the western Dra Valley, which equals Fauna C14 in Jansen et al. (2007). The oldest I. fusiformis record is from Sample 7-1 at Hassi Talha (Bultynck \& Hollard 1980, pl. IV, fig. 1a, b). Apart from the index species, I. corniger ancestralis, I. corniger leptus, I. rectirostratus, I. cf. rectirostratus (Fig. 27P), I. cf. werneri Weddige, 1977 (Fig. 27E), and the oldest Caud. culicellus culicellus (Bultynck \& Hollard 1980 , pl. IV, fig. 15a-c) form a very characteristic association. But most of our new samples from Bou Tserfine and Rich Tamelougou (Table 4) were surprisingly conodont-poor. The marker species is absent at both localities and Caud. ultimus (Fig. 27F) and I. corniger leptus (Fig. 27M) tend to be more common than other icriodids. In general, many icriodids are small and at early stages it is difficult to separate some taxa (e.g., Caud. ultimus and Caud. culicellus culicellus, Fig. 27H-K). Some juvenile forms identified as Caud. aff. sigmoidalis may represent a new taxon (Fig. 27R). Sample D91 at Bou Tserfine yielded a questionable (poorly preserved) Caud. culicellus altus, whilst the typical subspecies occurs only in one richer sample at Rich Tamelougou. Lat. bilatericrescens bilatericrescens continues from the lower Emsian and may be the only taxon at the base of the Hollardops Limestone (Fig. 27D). Only one questionable I. corniger ancestralis and one undoubted I. rectirostratus were found at Rich Tamelougou.

The subsequent nodules with "Latanarcestes" auct. in the upper part of the Brachiopod Marl Member have hardly any diagnostic conodonts. There are a few more Caud. ultimus at Rich Tamelougou (Bed 161 of Brett et al. 2012), poorly preserved Icriodus sp. (1 m higher), and a youngest relative of Caud. celtibericus, here identified as Caud. aff. celtibericus (Fig. 29M). The regionally very restricted conodont record of the pelagic "Latanarcestes" level is remarkable.

Very typical assemblages of the fusiformis Zone enter also in the sandy limestones at the top of the Rich 3 Sandstone Member of the eastern Dra Valley succession (El Anhsour, Samples I, II). Icriodus fusiformis (Fig. 25A-D), I. corniger ancestralis (Fig. 25H, I), and Caud. culicellus culicellus (Fig. 25J-L) are accompanied by I. ovalis sp. nov. (Fig. 25E-G). Icriodus homorectus follows in the second sample (Fig. 25M-P), which is also characterized by the rare re-appearance of Lat. beckmanni sinuatus and by a drastic abundance reduction of I. fusiformis.

The fusiformis Zone continues in the basal Timrhanrhart Formation of the eastern Dra Valley (Bultynck \& Hollard 1980, Bultynck in Ebbighausen et al. 2004). At El
Anhsour, I. praerectirostratus sp. nov. enters in Sample 2 (Fig. 25Q-W), followed by I. rectirostratus in Sample 8. This succession documents the potential for a future zone subdivision.

Bultynck (1985) recorded icriodid assemblages of Fauna $\mathrm{Vb}$, but with restricted diversity, from the higher Er Remlia Formation of the SW (Ou Driss, Sample 11 with Caud. culicellus, pl. 5, fig. 6) and northern Maider (Tizi n'Ikouâch, Samples 1, 2 with I. rectirostratus).

The fusiformis Zone correlates with a fauna of the Hierge Formation of the Ardennes (Bultynck \& Godefroid 1974), with Fauna VII of Bultynck (1976) from the Sierra Guadarrama of Spain, faunas from the upper Schönau Limestone and below the Rupbach Slate of the Rhenish Massif (Weddige \& Ziegler 1977, Requadt \& Weddige 1978), a typical assemblage from Reun ar C'Hrank in the Armorican Massif (Bultynck \& Morzadec 1979), Fauna I from the Lahn area of the Rhenish Massif (Weddige \& Requadt 1985), the upper Oued Akresch Formation of the Moroccan Meseta (Benfrika et al. 2007), conodont Step 22 of Carls et al. (2002, based on the entry of Caud. culicellus), and the Cantabrian corniger ancestralis Zone of García-López (1987) and García-López \& Sanz-López (2002). An alleged occurrence together with lower Emsian polygnathids in the Kabylei (northern Algeria, Gélard et al. 1978), is based on a different Caudicriodus. Beyond Europe, the fusiformis Zone can be recognized as the oldest Devonian unit in the Saradzhlin Suite of Transcaucasia (Nakhichevan autonomous region, Mamedov \& Rzhonsnitskaya 1985). The index species is even known from Tibet (Rao \& Yu 1985), I. corniger ancestralis from South China (Bai et al. 1982), and I. rectirostratus from the patulus Zone of Western Yunnan (Baoshan Block, a Gondwana-derived terrane, Carls \& Gong 1992). Such isolated occurrences improve the potential to use the base of the fusiformis Zone for chronostratigraphic definition.

Icriodus corniger corniger Zone. - Fauna VIa with I. corniger corniger of Bultynck \& Hollard (1980) was based on limited evidence from the Sellanarcestes Limestone of the lower Timrhanrhart Formation of the eastern Dra Valley. The best representation was from Targa Kheniga (Sample 22-3), where the index species was found together with Caud. culicellus culicellus, I. fusiformis, and I. rectirostratus. A re-sampling at Oufrane (Bed 11 of Ebbighausen et al. 2011) was unsuccessful; dissolved goniatites contained only Caud. culicellus culicellus (Fig. 29L), Neopanderodus and Belodella. Sample 14 at El Anhsour, from just below the Sellanarcestes Limestone, and Sample 16 from the lower subunit of the latter, yielded common I. rectirostratus and I. aff. corniger. The latter lacks the asymmetric posterior outer extension of the cavity but is provisionally taken as an indicator of the corniger corniger Zone. Latericriodus beckmanni sinuatus re-appears in this inter- 
val (Fig. 25Y). Specimens of Caud. culicellus culicellus are not typical (see aff. determination in Fig. 24).

Assemblages with I. corniger corniger and I. rectirostratus continue as part of Faunas VIb to VII through the higher part of the Lower Member of the Timrhanrhart Formation, sometimes accompanied by juvenile Caud. culicellus culicellus and I. aff. fusiformis (at Foum Timrhanrhart, Bultynck \& Hollard 1980).

The Sellanarcestes Limestone Member of the western Dra Valley yielded Fauna VIa, the lower part of the corniger corniger Zone, at three localities, Tjafane, Oui-n-Mesdoûr, and Hassi Talha (Bultynck \& Hollard 1980). There are I. corniger, I. rectirostratus, and Caud. culicellus culicellus. A new sample from Rich Tamelougou was extremely conodont-poor and lacked icriodids. The overlying siliciclastics (Bou Tserfine and Rich 4 Members) have not been sampled for conodonts.

In general, conodont faunas from the basal Anarcestes Limestone of the Tafilalt are also poor. The second bed with very abundant Sellanarcestes and Anarcestes yielded at Erg Kseir two I. corniger corniger? in association with Caud. culicellus culicellus (Fig. 29H, I), Neopanderodus, and Belodella. The fourth goniatite bed, with rare Achguigites, produced only Caud. culicellus culicellus (Fig. 29C, D) and the named shallow-water genera. Klug (2002) noted I. corniger from the Sellanarcestes beds at Jebel Ouaoufilal West. At Hamar Laghdad South (Samples HLS II-1 and II-2), I. rectirostratus is the only icriodid (Fig. 17P-U). There are none at Ouidane Chebbi further to the east (Belka et al. 1999). This illustrates some faunal difference between localities of the Tafilalt Basin and Platform. Icriodus corniger corniger has also been found at the top of the Anarcestes Limestone, in a sample of the patulus Zone of Jebel Ouaoufilal West (Klug 2002). It continues at Hamar Laghdad South, above the last I. rectirostratus of the Tafilalt (Sample HLS II6), into the basal Eifelian (Sample HLS II-7), where it is accompanied by a single Caud. culicellus altus Weddige, 1985 (in Requadt \& Weddige 1985).

A better development of the corniger corniger Zone can be found in the Maider. At Ou Driss (Sample 12) and Tizi n'Ikouâch (Sample 3), I. corniger corniger enters at the top of the Er Remlia Formation (Bultynck 1985, Fauna $\mathrm{VIa} / \mathrm{VIb})$. I. rectirostratus and Lat. beckmanni ssp. are associated. Above, in the Tazoulait Formation (Faunas VIb-c), Caud. culicellus culicellus re-appears (Ou Driss, Sample 17, Ouhlane, Samples 5, 6, Bultynck 1985). The Emsian part of the El Otfal Formation yielded I. corniger corniger, I. corniger leptus (only at Ouahlane), I. aff. fusiformis (only at Tizi n'Ikouâch), and I. rectirostratus but, as in the Tafilalt, only the first taxon survives into the basal Eifelian (Bultynck 1985).

The regional corniger corniger Zone correlates with the corniger corniger Zone of the Cantabrian Mountains
(García-López 1987, García-López \& Sanz-López 2002). It also can be recognized in the eastern part of the central Meseta (see Moulay Hassane data in Lazreq 1990). The precise correlation between the first appearances of $I$. corniger corniger and L. bultyncki is regionally masked by facies influences. Currently it seems that I. corniger corniger appears somewhat earlier, in LD IV-C, before the entry of Anarcestes (Fig. 31).

Lower Eifelian. - The Anti-Atlas corniger corniger Zone includes early upper Emsian to basal Eifelian strata. Caud. culicellus altus (Fig. 18A, B), I. corniger corniger (Fig. 18D-F), and I. aff. corniger (Fig. 18C) reach the basal Eifelian (Sample HLS II-7). The subsequent lower Eifelian is characterized by the radiation of new, zonally diagnostic icriodids, such as I. amabilis (Fig. 18J-L), I. struvei, I. introlevatus (Fig. 18G-I, Sample HLS II-11), and others (Bultynck \& Hollard 1980, Belka et al. 1997, Gouwy \& Bultynck 2002, Becker \& Aboussalam 2013). Since I. struvei enters first at Bou Tchrafine and Jebel Amelane, it can be used as the marker for a regional struvei Zone that begins high in the partitus Zone.

\section{Regional Anti-Atlas spathognathodid zonation} (Fig. 30)

(Regional) Criteriognathus miae Zone. - The new, oldest evidence for the zonal marker comes in the Tafilalt from a Pragian sample (P/E2) ca $10 \mathrm{~m}$ below the Deiroceras Limestone at section BTN, which belongs to the steinachensis Zone. This lowers the entry of the marker of Fauna Ib sensu Bultynck \& Hollard (1980) to a position much below their Fauna Ia. Therefore, Ia and Ib faunas cannot be distinguished. The index species is then widespread in the basal Deiroceras Limestone of El Khraouia (Bed 15a, Fig. 21B), at Jebel Ihrs (Bed 16a, Fig. 5I), and Bou Tchrafine West (Sample BTW0). It continues in the middle (El Khraouia, Bed 15c, and Sample BTN BK596) and upper Deiroceras Limestone (Jebel Ihrs, Bed 16c, Fig. 7J, K; Ouidane Chebbi, Belka et al. 1999, Bou Tchrafine North, Sample BTW1, Fig. 18M, N, and Jebel el-Mrier). It occurs also in the lower Bou Tiskaouine Formation of Ou Driss (Bultynck 1985). "Pandorinellina" exigua (Philip, 1966) is so far only known from the basal Deiroceras Limestone of Ouidane Chebbi (Section I, Sample 20, Belka et al. 1999).

The regional miae Zone ranges into the lower Anetoceras Limestone, e.g., at Jebel Ihrs and Bou Tchrafine West (Fig. 180, P), but the last records of the index species are from the middle part of the unit (Jebel Ihrs, Bed 25a; Bou Tchrafine West, Sample BTW3). At corresponding levels of the Maider it has been found together with Erb. advolvens in the higher Bou Tiskaouine Formation of the Jebel Issimour (Plodowski et al. 2000). In the eastern Dra 
Valley it occurs in the Lower Member of the Mdâouer-el-Kbîr Formation (Bultynck \& Hollard 1980, Sample 26-1).

The Pragian entry of the miae Zone in the Tafilalt correlates roughly with records of the index species from the middle Pragian serratus Zone of Bohemia (Slavík 2004b). In the eastern Pyrenees Crit. miae was found in association with polygnathids of the kitabicus Zone (Sanz-López 2002), in Australia (Mawson \& Talent 1994, Colquhoun 1995), the Western Karakorum, Pakistan (Gaetani et al. 2008), and in the eastern Urals (Snigireva \& Nasedkina 1995 ) in the $c a$ middle Pragian. There is an upper Pragian occurrence in the celtibericus Zone of the Moroccan Meseta (Benfrika et al. 2007). In Uzbekistan there is a long overlap with Monograptus faunas (e.g., Mashkova 1979, Yolkin et al. 2008). But the miae Zone of Tadzhikistan (Bardashev \& Ziegler 1992) was placed in the lower Pragian. Alleged much earlier, middle Lochkovian records of Crit. miae from Spain (García-López et al. 1990) and Sardinia (Corradini \& Corriga 2012) require further investigation. Just recently, Mavrinskaya \& Slavík (2013, fig. 6F) assigned very close upper Lochkovian relatives to "Pandorinellina cf. miae".

Because Crit. miae has such a wide distribution, e.g., in the Russian Arctic with very different and endemic conodonts (Baranov \& Al'khovik 2003, Baranov 2012), it could be of high value for international correlation. However, the facies-controlled, strong regional range differences and rather generalized morphology much reduce its significance.

Criteriognathus steinhornensis Zone. - The globally wide-spread (e.g., Klapper \& Johnson 1980) zonal index occurs commonly or in masses well above the base of the Anetoceras Limestone of the Tafilalt, for example at Jebel Ihrs (Beds 21a-26b, Figs 8K, 9D, E), Bou Tchrafine West (Sample BTW2-4, Fig. 18Q), North (Samples BTN 31-1 to 31-4), and Northwest (Sample BT-Kl, Fig. 28D-F), Jebel el-Mrier (Samples AL RTB 7a, Fig. 22D, and AL RTB 7b), and Ouidane Chebbi (Samples 27/28 of Belka et al. 1999; new Sample OCh-Anet, Fig. 28F, associated with common Belodella, Fig. 28I, J). The steinhornensis Zone is also developed in the upper Bou Tiskaouine Formation of the SW (Ou Driss, Bultynck 1985) and northern Maider (Jebel Issimour, Plodowski et al. 2000). There is a first record of the index species for the eastern Dra Valley (auxiliary locality Rich el M'Bidia, Fig. 18R, lower Mdâouer-el-Kbîr Formation).

Criteriognathus steinhornensis ranges more rarely in the Tafilalt into the lower (Bou Tchrafine West, Sample BTW4b, see also Bultynck 1985) and top of the Mimagoniatites Limestone (Jebel el-Mrier, Bed 20a), with a facies-controlled record gap in the middle part of that unit. It is absent from the polygnathid faunas of the laticostatus Zone and Anarcestes Limestone.
Criteriognathus steinhornensis, excluding all previous "subspecies", defines the "zone of Spathognathodus steinhornensis" in Carls et al. (1972), Fauna IV in Bultynck \& Hollard (1980), and conodont Step 21 of Carls \& Valenzuela-Ríos (2002). At Jebel Ihrs, its base correlates $c a$ with the base of the Eol. catharinae Subzone, which is supported by the La Grange data of Bultynck (1989), and with an epibole of Lat. beckmanni beckmanni. Carls \& Valenzuela-Ríos (2002) suggested that there is no range overlap of Crit. miae and Crit. steinhornensis in Celtiberia but that both overlap with a smaller-sized new species, which was informally named "Ozarkodina" sp. M. Currently we cannot follow that distinction but observe in the Anetoceras Limestone of the Tafilalt a rather gradual replacement of Crit. miae by steinhornensis, with an overlap high in the lower part of the unit. The index species is widespread in the higher lower Emsian of different blocks of the western Prototethys, such as the Moroccan Meseta (Benfrika et al. 2007), Kabylia of northern Algeria (Gélard et al. 1978), Peloritanian Mountains of southern Italy (Somma et al. 2013), Pyrenees (Buchroithner 1978), and Central Carinthia (Austria, Buchroithner 1979). The significance of the steinhornensis Zone for international correlation is underlined by far distant records reaching Central Iran (Nasehi 1997), Tadzhikistan (Bardashev \& Ziegler 1992), SW Mongolia (Ruzhentsev 2001), the Baoshan block of Yunnan (Carls \& Gong 1992), the Amur region of the Russian Far East (Eikhvald 2008, Baranov et al. 2014), and Nevada (e.g., Klapper \& Johnson 1980). The short overlap interval of Crit. miae and steinhornensis was met by a single sample from the Karakorum (northern Pakistan, Talent et al. 1999).

Criteriognathus steinhornensis has been reported to range into the lower part of the serotinus Zone in Bohemia (Klapper et al. 1978), Uzbekistan (Apekina \& Mashkova 1978), Thailand (Long \& Burrett 1989), and on Sardinia (Barca et al. 1986). But it disappears near the end of the lower Emsian in the eastern Anti-Atlas. The revised steinhornensis Zone should not be confused with the much more extensive (upper Silurian to Emsian) steinhornensis biozone sensu Maskkova (1972), which includes older representatives of various genera.

"Ozarkodina" carinthiaca Zone. - The index species enters in its Austrian type region in the serotinus Zone (e.g., Schönlaub 1985). In the Barrandian it ranges from the basal serotinus Zone to the lower part of the partitus Zone (e.g., Klapper et al. 1978). A similar range has recently been reported from the Istanbul region of NW Turkey (Saydam-Demiray \& Capkinoglu 2012) and, previously, from the Harz Mountains of Germany (e.g., Luppold 1984), the Armorican Massif (Lardeux \& Weyant 1993), Malaysia (Lane et al. 1979), and Uzbekistan (last update in Yolkin et al. 2008). Gagiev \& Rodygin (1988) claim a 
slightly longer range (lower costatus Zone) in Siberia. At Hamar Laghdad South it has only been found right around the Lower/Middle Devonian boundary (Samples HLS II-6, Fig. 16Q-S, and HLS II-7). However, there is a significantly older, top lower Emsian specimen from the lower Mimagoniatites Limestone of Bou Tchrafine North (Sample BTN 31-5), which overlaps with Crit. steinhornensis. So far, the species is lacking in the Maider and Dra Valley.

The generic position of "Oz." carinthiaca is unresolved. The Pa element has similarities with some upper Emsian species of Amydrotaxis, for example Am. maxillaris Baranov, 1991. Consequently, Bardashev et al. (2002, p. 392) included carinthiaca in that genus.

\section{Anti-Atlas Emsian conodont - ammonoid correlation (Fig. 32)}

\section{Previous work on Emsian ammonoid stratigraphy of the Anti-Atlas}

Data on lower Emsian ammonoid stratigraphy of the Tafilalt were published by Hollard (1963b, 1967), Massa (1965), Becker \& House (1994), and Belka et al. (1999). The regional zonation was erected by Klug (2001), with some additions in Becker \& House (2000), Klug et al. (2008), Kröger (2008), De Baets et al. (2010), Becker \& Aboussalam (2011), and De Baets et al. (2013). Following a first outline in Hollard (1974) and Bultynck \& Hollard (1980), Becker \& House (1994) established the upper Emsian zonation, with more detailed data in Klug et al. (2000), Klug (2002), and by Becker in Webster et al. (2005).

Emsian ammonoid data for the Maider are more limited (e.g., Hollard 1974, Bultynck 1985, Plodowski et al. 2000). New collections were made at the northern margin, including a new record of Erbenoceras from the upper Bou Tiskaouine Formation, abundant "Latanarcestes" auct. from the Er Remlia Formation, and Sellanarcestes wenkenbachi, other species of the genus, and still abundant "Latanarcestes" auct. from the Tazoulait Formation (Stichling 2013). There are only a few localities with lower Emsian ammonoids in the Dra Valley (Hollard 1963b, 1978; Bultynck \& Hollard 1980; Becker et al. 2008; De Baets et al. 2010). The upper Emsian zonal succession of the Maider and Dra Valley has recently been summarized by Ebbighausen et al. (2011).

\section{Ammonoid-conodont correlation in the Tafilalt}

The oldest ammonoid zone recognized here (Lower Devonian III-A, Becker \& House 1994) is the Devonobactrites obliqueseptatus Zone. It is sandwiched between the celtibericus Zone of the "Pragian Limestone" below and the bi- latericrescens gracilis Zone (= regional excavatus Morphotype 114) of the basal Deiroceras Limestone above. It seems to correlate at least partly with the level of the first Lat. bilatericrescens gracilis and the Neomonograptus atopus Zone of Bohemia (e.g., Slavík 2004a). This is supported by an overlap with the last Guerichina and Nowakia (Turkestanella) anteacuaria Alberti, 1993 (see Alberti 1998). Specimens from the "Pragian Limestone" of Filon Douze (southern Tafilalt) identified by Kröger (2008) as ?Bactrites sp. did not show a ventral siphuncle. These alleged oldest bactritids of the Anti-Atlas are here excluded from the group. Kröger (2008) also mentioned Devonobactrites from the Deiroceras Limestone but did not describe or illustrate these specimens.

As discussed by Becker \& Aboussalam (2011) an alleged oldest Chebbites from the top Deiroceras Limestone, which defined Zone A of Klug (2001), is not accepted until further confirmation (compare the query in De Baets et al. 2010).

The highly diverse faunas of the Erbenoceras advolvens Zone, with Metabactrites formosus Bogoslovskiy, 1972 and Chebbites reisdorfi Klug, 2001 as alternative regional markers, fall in LD III-B sensu Becker \& House (1994) and define Zone B of Klug (2001). Due to the dominance of loose collections, Gyroceratites laevis Eichenberg, 1931 is not used here for a subdivision. The advolvens Zone is sandwiched between the upper part of the regional excavatus Morphotype 114 Zone (top of Deiroceras Limestone) and the catharinae Subzone (upper gronbergi Zone) or latus Zone of the lower Anetoceras Limestone. Therefore, it can be correlated with the main gronbergi Subzone. It overlaps with Nowakia (Now.) zlichovensis Bouček, 1964 and Now. (Now.) praesulcata Alberti, 1982 in its lower part (Alberti 1998).

The Anetoceras obliquecostatum Zone (lower LD III-C, Fauna C of Klug 2001) can be directly correlated with the steinhornensis Zone, based on Sample OCh-Anet. However, since the zonal marker occurs near the base of the Anetoceras Limestone at Jebel Mech Irdane and Ras el Kebber (Klug 2001), the base of the obliquecostatum zone is also correlated with the base of the catharinae Subzone and with the basal latus Zone of the icriodid succession. Alberti (1998) reported Nowakia cf. praecursor at this position.

The Klugites gesinae Zone (upper LD III-C, Fauna D in Klug 2001) falls in the higher part of the steinhornensis Zone, based on Sample BT-Kl from middle parts of the Anetoceras Limestone. Anet. aff. solitarium from Ouidane Chebbi and a new Teicherticeras from Jebel el-Mrier belong to the same zone. Alberti (1998) shows Nowakia (Now.) barrandei Bouček \& Prantl, 1959 ca in the same interval. Due to the lack of illustration it is possible that a rather early Mimagoniatites from Jebel Amelane noted in Alberti (1998) in fact belongs to Klugites gen. nov. Both 
genera share rectiradiate growth lirae with deep flank sinus and a concave whorl zone.

The Mimagoniatites fecundus Zone of the Mimagoniatites Limestone falls in LD III-D (sensu Becker \& House, 1994) and Zone E of Klug (2001). The directly associated conodonts are too poor for a comparison with the polygnathid zonation. As discussed in Becker \& Aboussalam (2011), a tentative correlation with the inversus Zone is based on Spain (García-López et al. 2002) and the Khodzha-Khurgan Gorge of the Kitab Reserve (review in Becker et al. 2010). Hollard (1974) documented that the Mimagoniatites Zone extends to the northern Maider.

The light-grey limestones at the top of the Mimagoniatites Limestone have no goniatites. The alleged occurrence of a Mimosphinctes at Jebel Amelane (Massa 1965 , p. 66), the index genus of LD III-E sensu Becker \& House (2000), has never been substantiated by subsequent findings. Currently there are no Tafilalt goniatite faunas, which fall in the laticostatus Zone.

As shown by Alberti $(1980,1981)$ and briefly noted by Becker \& House (2000), the basal Daleje Shale Equivalents contain a distinctive, goethitic/limonitic Gyroceratites-rich fauna, still without anarcestids. New rich collections from the plain between the sections Bou Tchrafine North and Hamar Laghdad South provide sufficient evidence to establish a Rherisites tuba Zone (UD IV-A sensu Becker \& House 1994) below the onset of "Latanarcestes" auct., "Praewerneroceras" hollardi Becker \& House, 1994 and other early anarcestids ("noeggerathi Zone", LD IV-B). Sellanarcestes eos (LD IV-C) follows probably higher in the middle to upper parts of the Daleje Shale Equivalents. This interval cannot be correlated with conodonts in the Tafilalt and falls in the long regional laticostatus-bultyncki Interregnum.

The lower Anarcestes simulans Zone (LD IV-D1) begins at the base of the Anarcestes Limestone. The limited evidence from Samples EKs-B and HLS II1 place the first beds with Sell. wenkenbachi, but still without Achguigites or Sell. neglectus, in the lower part of the corniger corniger and bultyncki zones. But the dissolved goniatites mostly yielded specimens of Neopanderodus (Fig. 29F, G, J, N) and Belodella (Fig. 29B, E), which is not in accord with current biofacies models. Data from Ouidane Chebbi (Belka et al. 1999, in combination with Klug 2002) and Hamar Laghdad South (Bultynck \& Hollard 1980) enable us to recognize the bultyncki (Sub)Zone also slightly higher, above the first Sell. neglectus. Sellanarcestes seems to range into the cooperi cooperi Subzone (Sample HN-TA29). There are no good conodont data for the upper simulans Zone (lower LD IV-D2 sensu Becker \& House 1994), without Sellanarcestes. Klug (2002, Jebel Ouaoufilal) provided a correlation of the Anarcestes lateseptatus Zone (upper LD IV-D2) with the patulus Zone, which is supported by the new Sample OCh-An and Sample HLS II6.

\section{Ammonoid-conodont correlation in the Dra Valley}

In the eastern Dra Valley (Mdâouer-el-Kbîr Ravine, Sample 26-1), Erb. advolvens is directly associated with icriodids of the bilatericrescens Zone s.l. (Fauna II of Bultynck \& Hollard 1980) and Crit. miae. This enables a correlation with the Erb. advolvens Zone (LD III-B) of the Tafilalt (Metabactrites-Erbenoceras Shale), which is supported by associated Nowakia (Dmitriella) cf. praecursor Bouček, 1964 and Now. cf. zlichovensis (see Hollard 1978), as in the Metabactrites-Erbenoceras Shale. De Baets et al. (2010) came to a similar conclusion. Their higher fauna from Mdâouer-el-Kbîr with Anetoceras and Lenzites (= Klugites gen. nov., LD III-C), as in the steinhornensis Zone of the Anetoceras Limestone of the Tafilalt, was not sampled for conodonts. Our sample with $L$. aff. inversus (inversus Zone) is from $c a$ five meters higher, if we accept the measurements in the section log of De Baets et al. (2010, fig. $2 \mathrm{~B}$, not $2 \mathrm{~A}$, as claimed in the figure caption).

A record of Mimagoniatites fecundus from the upper part of the Rich 3 Sandstone Member at Foum Zguid (Jansen et al. 2004, 2007) indicates LD III-D but it comes from clastics without conodonts. Hollard (1978) listed Latanarcestes from the top of the Mdâouer-el-Kbîr Formation. Based on conodonts from El Anhsour (Samples I, II, see Bultynck \& Hollard 1980) this local record of the "noeggerathi Zone" (LD IV-B) can be correlated with the fusiformis Zone.

The Sellanarcestes Limestone (Sell. wenkenbachi Zone, LD IV-C) of the subsequent lower Timrhanrhart Formation falls in the basal corniger corniger Zone, based on limited data from Targa Kheniga (Bultynck \& Hollard 1980, Fauna VIa, Sample 22-3). However, this could not be substantiated by a new sample from Oufrane, which also lacks polygnathids. Sample 16 from El Anhsour yielded only abundant $I$. aff. corniger, $L$. inversus, and $L$. aff. inversus. The two latter records indicate that Sellanarcestes enters in the regional laticostatus-bultyncki Interregnum. Above, the Anarcestes simulans Subzone, with Achguigites tafilaltensis Klug, 2002 and Sell. neglectus, falls in the bultyncki Zone, based on data in Bultynck \& Hollard (1980, Fauna VIb from El Annsa and Foum Timrhanrhart). It is still open whether the following An. crassus Subzone of Ebbighausen et al. (2011), which includes the youngest Sellanarcestes, belongs in the L. cooperi cooperi Subzone.

In the western Dra Valley, a single loose Erbenoceras from the upper Oui-n-Mesdoûr Formation falls in the local monospecific Lat. bilatericrescens bilatericrescens assemblage high in the lower Emsian (Becker et al. 2008). Higher, a single Mimagoniatites tabuliformis Kullmann, 1960 Group from the top of the Hollardops Limestone Member of Bou Tserfine (Becker et al. 2008) is younger 
than the fusiformis Zone faunas described by Bultynck \& Hollard (1980) and Jansen et al. (2007) from the main part of the unit. The "noeggerathi Zone" (LD IV-B) of the overlying upper part of the Brachiopod Marl Member (Khebchia Formation) is associated at Rich Tamelougou with zonally non-diagnostic Caud. ultimus and Caud. aff. celtibericus. The base of the Sellanarcestes Limestone Member, which may belong to the Sell. wenkenbachi Zone (LD IV-C), produced at Hassi Talha the corniger corniger Zone (Fauna VIa of Bultynck \& Hollard 1980, Sample 5-2). The main part of the unit falls in the lower An. simulans Zone (LD IV-D1) and in the bultyncki Zone (Hassi Talha, Sample 5-1, Fauna VIb) but the polygnathid evidence is very poor. The cooperi cooperi Subzone has not yet been verified within the higher Sellanarcestes-Anarcestes faunas. The overlying assemblage of the upper An. simulans Zone (lower LD IV-D2, without Sellanarcestes), found by Becker et al. (2008) at the base of the Bou Tserfine Member, has not yet been correlated with the conodont succession.

\section{Emsian event stratigraphy of the Anti-Atlas (Fig. 1)}

\section{Tafilalt}

The marked transgression at the base of the Devonobactrites Shale has been correlated by Becker \& Aboussalam (2011) with the Bohemian Basal Zlíchov Event. In the definition of Chlupáč \& Kukal (1986, 1988), however, this is a regional and slightly younger facies change at the base of the Zlíchov Limestone. It coincided with the disappearance of the dacryoconarid Guerichina, which ranges into the upper part of the Devonobactrites Shale (Alberti 1998). Due to its position well above the base of the Caud. celtibericus Zone and in the upper range of the Nowakia (Turkestanella) acuaria (Richter, 1854) Group, the first deepening pulse of the Tafilalt Emsian is more likely correlated with the significant short-termed transgression that enabled within the Dvorce-Prokop Limestone of Bohemia ("upper Pragian" in a classical sense) the sudden influx of a last graptolite fauna with Neomonograptus atopus (Bouček, 1966) (atopus Event of Becker et al. 2012; see Chlupáč \& Lukeš 1999 and Slavík 2004a).

The significant deepening of the Chebbi Event (Becker \& Aboussalam 2011), at the base of the Metabactrites-Erbenoceras Shale, led to one of the most significant marine evolutionary innovations of the Middle Palaeozoic, the sudden and very fast appearance, spread and radiation of early ammonoids. Similarly early ammonoid faunas occur in the deepening pulse of the Taravale Limestone of Victoria (Mawson 1987a). The Chebbi Event needs further documentation in other regions, in an interval slightly above the first Nowakia (Now.) zlichovensis and near the base of the gronbergi Zone (below the nothoperbonus Zone) or between the successive entries of Lat. bilatericrescens bilatericrescens and Lat. latus, within conodont Step 19.

The Upper Zlíchov Event (UZE) of García-Alcalde (1997) was placed at the base of the Vañes Beds of the Palentine Domain of the Cantabrian Mountains and just above the base of Member d4b $\alpha$ of the Mariposas Formation of the Eastern Iberian Chains. The first level lies slightly below the base of the inversus Zone and well above Lat. latus (García-López et al. 2002), near the boundary of the barrandei and elegans zones of the dacryoconarid succession (García-Alcalde 1998, Truyols-Massoni 1998). In the second region, the UZE occurs within conodont Step 21 (steinhornensis Zone) of Carls \& Valenzuela-Ríos (2002). This enables us to correlate the minor deepening and the change to the more bituminous Mimagoniatites Limestone with the Upper Zlichov Event, as suggested by Becker \& Aboussalam (2011). Only a few goniatite species of the Anetoceras faunas continue regionally into the upper part of the lower Emsian. The wide spread of Nowakia (Now.) elegans (Barrande, 1867) in the Mimagoniatites Limestone (Alberti 1980, 1981, 1998) confirms the dacryoconarid correlation of the Palentine Domaine. It proves that the first Daleje Transgression of the Barrandian sensu Ferrová et al. (2012; not sensu Chlupáč \& Kukal 1988), with co-occuring Now. barrandei and Now. elegans, correlates with the Upper Zlíchov Event.

The Daleje Event (sensu Chlupáč \& Kukal 1988) is marked in the Tafilalt by a very sudden change from condensed limestone to thick silty shales with goethitic fauna. It correlates with the main Daleje Transgression of Bohemia, which flooded, for example, the upper Chynice Limestone (Ferrová et al. 2012). The last Tafilalt limestones below the Daleje Shale Equivalent tend to be lighter grey than the true Mimagoniatites Limestone. Now. cancellata may enter in these last beds (Alberti 1980, 1981). The study of neritic faunas of the Mimagoniatites Limestone will be important to document which taxa survived into the final Zlíchovian and which co-existed at the very top with the first Now. (Now.) cancellata (Richter, 1854). The (main) Daleje Event falls in the Tafilalt clearly in the lower part of the laticostatus Zone.

\section{Maider}

The Chebbi Event can be recognized in the Maider as the base of a shaly interval in the middle of the Bou Tiskaouine Formation. A manifestation of the Upper Zlíchov Event is not yet evident, but Bultynck (1999) noted Mimagoniatites from the top of the Bou Tiskaouine Formation at Ou Driss. The Daleje Event (s. str.) is very pronounced at the base of 
the Er Remlia Formation. Some sections, for example at the western end of the Ouahlane Syncline, contain a distinctive basal siltstone. In others (e.g., Boultan South, Stichling 2013) the change from thick limestone to shale is as sharp as in the Tafilalt.

\section{Dra Valley}

The Rich 2 Sandstone Member masks possible influences of earliest Emsian events. The base of the Mdâouer-el-Kbîr and Oui-n-Mesdoûr formations can tentatively be correlated with the Chebbi Event. This is more likely than the correlation with the Basal Zlíchov Event, as proposed by Ouanaimi \& Lazreq (2008). It has been noted as a Transgressive System Tract by these authors and Lubeseder et al. (2009). The limestone with Fauna C11 of Jansen et al. (2007) forms an exception and deserves further studies.

In the eastern Dra Valley the Daleje Event is not prominent within the Rich 3 Sandstone Member. It may be expressed by the change from quartzites to sandy brachiopod coquina limestones. A later transgressive pulse, which correlates with $c a$ the middle part of the Daleje Shale Equivalents, is represented by the Trilobite Limestone at the base of the Timrhanrhart Formation. In the western succession, the Daleje Event is perceptible as a minor hypoxic interval with black shales and dark limestone at the base of the Hollardops Limestone Member, above a light-grey marl package at the top of the Oui-n-Mesdoûr Formation (for example, at Bou Tserfine, Becker et al. 2004c). This TST is recognized in Ouanaimi \& Lazreq (2008, R4a) and, with a query, in Lubeseder et al. (2009). There is no evidence for an unconformity in the western Dra Valley, which correlates with the lowstand of the Rich 3 Sandstone. A first upper Emsian maximum flooding occurred in the upper part of the Brachiopod Marl Member ("Latanarcestes" Beds, upper fusiformis Zone). Based on a maximum of (primarily) pyritic faunas with "Latanarcestes" and others, it seems to correlate with a deepening peak within the middle Daleje Shale Equivalents of the Tafilalt. A second sudden deepening is evident at the base of the Bou Tserfine Member, which contains goethitic Anarcestes, Mimagoniatites and other fauna in the syncline W of the Rich Tamelougou, SW of Torkoz (Becker et al. 2008). It is correlated with the extinction of Sellanarcestes but not with a sedimentological event in the Tafilalt and Maider.

\section{Chronostratigrapic implications}

The current basal Emsian GSSP at the base of the kitabicus Zone cannot be traced with the help of conodonts in the Anti-Atlas, mostly since there are no critical polygnathids.
Based on the disappearance of Lat. steinachensis Morphotype eta near the base and the onset of the celtibericus Zone in the lower part of the regional "Pragian Limestone", it may become possible to approximate the current GSSP level (planned upper Pragian substage level) but the polygnathid-icriodid correlation is currently not precise. It is also difficult to recognize regionally a future basal Emsian defined by the onset of Eol. excavatus Morphotype 114, which appears with a facies/sampling-controlled delay at the base of the Deiroceras Limestone. It is well possible that the first appearance of the index taxon falls in the Tafilalt and Maider in the interval of the underlying, deeply weathered Devonobactrites Shale or corresponding lower member of the Bou Tiskaouine Formation, which are difficult to sample for conodonts. An alternative definition based on the entry of Lat. bilatericrescens gracilis (Slavík, 2004a) faces the same problem. The contemporaneous Rich 2 Sandstone Member of the Dra Valley is also unsuitable for conodont search but offers a relevant brachiopod record.

The Daleje Event (s. str.) should remain the primary marker for a lower/upper Emsian substage boundary, not much lower levels, such as the base of the nothoperbonus Zone or the level of the Upper Zlíchov Event, including the base of the Nowakia (Now.) elegans Zone. The first can be projected to the basal Anetoceras Limestone, just below the onset of Anetoceras. The second level lies outside the Anti-Atlas well within the range of typical and partly rich lower Emsian/Zlíchovian Anetoceras faunas, which always have been regarded as typical for the lower Emsian. These also extend into the laticostatus Zone (e.g., Becker et al. 2010). Regionally, there is no evidence for a sudden and simultaneous extinction of many goniatite taxa at a sharp boundary but this does not alter their reception as typical lower Emsian faunal elements. A too low placing of the future intra-Emsian substage boundary would seriously alter the classical meaning of marker taxa and create confusion because a wealth of old literature would have to be re-interpreted. As shown in the case of other chronostratigraphic boundaries (e.g., base of the Emsian), a significant deviation from classical definitions finds little or no acceptance in the wider geoscience community.

Because of the absence of suitable marker polygnathids, the I. fusiformis-I. corniger ancestralis-Caud. culicellus faunas provide a very distinctive evolutionary innovation episode just above the Daleje Event. Unfortunately, the group had a restricted palaeogeographic distribution (Klapper \& Johnson 1980, Bultynck 2003, Becker 2007). However, the range of some marker species, such as I. fusiformis, I. corniger ancestralis and I. rectirostratus, into various Asian crustal blocks increases the correlation potential of the level.

The intra-Emsian substage debate would benefit from more detailed dacryoconarid data from southern Morocco. 
Especially the precise range of Now. (Now.) cancellata, of transitional forms from Now. (Now.) elegans, and of possible homoemorphic taxa and subspecies should be established.

\section{Systematic palaeontology}

\section{Genus Criteriognathus Walliser, 1972}

Discussion. - Ozarkodina steinhornensis Ziegler, 1956 was designated by Walliser (1972) as type species of his new multi-element genus Criteriognathus. The restricted definition of the genus Ozarkodina, for example in Murphy et al. (2004), adds to the justification of the genus. It differs from Lower Devonian forms assigned to Pandorinellina by its wide basal cavity and more or less equidentate $\mathrm{Pa}$ elements, without prominent anterior teeth. It is unlikely that the latter group is the same phylogenetic lineage as the latest Givetian/Frasnian type group of Pandorinellina.

Crit. steinhornensis was clearly derived from Crit. miae, supported both by morphology and faunal successions in several sections (see Fåhraeus 1974). Although there is not yet a multi-element reconstruction for miae, it is currently best placed in the same ozarkodinid genus as its descendent.

\section{Eolinguipolygnathus Bardashev, Weddige \& Ziegler, 2002}

Type species. - Polygnathus dehiscens Philip \& Jackson, 1967.

Discussion. - As emphasized by Becker \& Aboussalam (2011), Polygnathus in the sense of its type species (Po. dubius Hinde, 1879) and related forms from the Givetian/Frasnian is characterized by a small basal pit under the anterior platform of the Pa element. Contemporaneous species with a large pit or with a wide basal cavity fall in different genera, such as Schmidtognathus and Klapperina. The Pa elements of early siphonodellids and related taxa (e.g., Becker et al. 2013c) can be especially similar to those of ancestral polygnathids. In a consistent taxonomy with clear differential diagnoses, it is not possible to include any polygnathids with wide basal cavity in Polygnathus (Becker 2012, 2013). Therefore, Bardashev et al. (2002) introduced three different genera for such forms.

The main difference between Eocostapolygnathus, with the type species Po. kitabicus, and Eolinguipolygnathus is the presence or absence of a "lingua", a posterior part of the platform ornamented mostly by transverse ridges. Forms with a "semicrossed" lingua (sensu Yolkin et al. 1994), with carina nodes superimposed on a lingua, were noted in the diagnosis of Eolinguipolygnathus. The lingua may be slightly interrupted by weak furrows, or it may be secondarily reduced (shortened or narrowed). This leaves transitional and secondarily changed forms that are difficult to assign. For example, the holotypes of Po. excavatus (re-illustrated in Klapper \& Johnson 1975) and Po. gronbergi posses a "semicrossed lingua". Both taxa, however, were assigned by Bardashev et al. (2002) to Eocostapolygnathus, which is not followed here. Costapolygnathus telfordi Bardashev, Weddige \& Ziegler, 2002 is a lower Emsian example in which a well developed lingua may have been secondarily fully interrupted by shallow adcarinal troughs, leaving a posterior carina that consists of very fine nodes. This species is more likely a relative of Eol. vigierei from the same locality (see the atypical vigierei paratype of Bultynck 1985, pl. 5, fig. 1a, b) than a late descendent of the Eoc. kitabicus lineage. Here we restrict Eocostapolygnathus to forms close to the type species (kitabicus, alkhovikovae Baranov, Slavík \& Blodgett, 2014, aragonensis Martínez-Pérez \& Valenzuela-Ríos, 2014, bardashevi Baranov, Slavík \& Blodgett, 2014, erinae Bardashev, Weddige \& Ziegler, 2002, hindei Mashkova \& Apekina, 1980, lezhoevi Baranov, Slavík \& Blodgett, 2014, rosae Martínez-Pérez, Valenzuela-Ríos \& Botella, 2010, sobolevi Bardashev, Weddige \& Ziegler, 2002, sokolovi Yolkin, Weddige, Izokh \& Erina, 1994, tamarae Apekina, 1989) and, with some reservation, the lenzi group (lenzi, juferevi = pierrei Bardashev, Weddige \& Ziegler, 2002, richi Bardashev, Weddige \& Ziegler, 2002).

Eoctenopolygnathus Bardashev, Weddige \& Ziegler (2002), with the type species Po. pireneae, is defined by a carina that extends posteriorly beyond a small, narrow platform. The genus should also be restricted to probable close relatives and descendents of the type species (pireneae, boersmai Bardashev, Weddige \& Ziegler, 2002, boucoti Savage, 1977, ?debaoensis Xiong, 1980 in Xiang et al. 1980, ivanovskyii Baranov, Slavík \& Blodgett, 2014, mawsonae Bardashev, Weddige \& Ziegler, 2000 (non mawsonae Long \& Burrett, 1989), savagei Bardashev, Weddige \& Ziegler, 2002). A posteriorly extended carina occurs also in juveniles of Emsian polygnathids with an adult lingua (e.g., Long \& Burret 1975, Klapper \& Vodrážková 2013, our population of L. inversus from El Khraouia). Baranov et al. (2014) suggest that the feature is also present in juvenile Eoc. lezhoevi, which is related to the type species, Eoc. kitabicus. A similar morphology may result from a secondary extreme narrowing of the lingua, for example in Eol. senckenbergi, or in the Givetian L. mucronatus (Wittekindt, 1966). It is possible that the lenzi Group was derived from Eoctenopolygnathus.

The acceptance of just one (Eocostapolygnathus, e.g., Becker et al. 2012) or of several genera for early polygnathids with large basal cavity remains a question of 
subjective taxonomic preference. But only, as far as ontogenetic developments, intraspecific variability, homoemorphy, and monophyly are strictly respected (compare the discussions in Mawson \& Talent 2003 or Klapper \& Vodrážková 2013). Subgenera are a taxonomic option but this creates very long names.

Linguipolygnathus Bardashev et al. (2002) differs from its ancestor, Eolinguipolygnathus, by the completed inversion of most of the basal cavity, creating a basal pit that becomes smaller during ontogeny (e.g., Klapper \& Vodrážková 2013), often with some asymmetric lateral extension (protuberances). In the Givetian, the genus is very distinctive from Polygnathus and shows partly a different facies distribution. In the Emsian, however, there are strong indications that the inversion of the basal cavity occurred iteratively in several lineages (e.g., phylogenetic models in Klapper \& Johnson 1975 and Bultynck 1989). There are species, such as Po. laticostatus or Po. cooperi, with only a very short or "semicrossed" lingua. The probable polyphyletic origin of Linguipolygnathus in its current scope and a subdivision of the genus into monophyletic taxa require further studies that lie beyond this contribution. Eucostapolygnathus Bardashev \& Weddige, 2003, based on the type species Po. costatus, is treated as a junior synonym of Polygnathus.

Eolinguipolygnathus excavatus (Carls \& Gandl, 1969) Figures 5J-Q, 6C, D, 6K, L, 7C-H, 7N-Q, 15A-D, 15G, 21D-F, 27L

*e.p. 1969 Polygnathus webbi excavata n. ssp.; Carls \& Gandl, pp. 193-195, pl. 18, figs 9-12 (only).

e.p. 1975 Polygnathus dehiscens Philip \& Jackson. - Klapper \& Johnson, pp. 72-73, pl. 1, figs 1-3, 7-12, 15, 16 (only) [figs 5, 6 and 13, $14=$ Eoct. lenzi].

1980 Polygnathus dehiscens Philip \& Jackson. - Bultynck \& Hollard, p. 25, fig. 10, pl. II, fig. 5a, b.

e.p. 1987a Polygnathus perbonus (Philip). - Mawson, pp. 276-277, pl. 34, figs 10, 11 (only).

1999 Polygnathus gronbergi Klapper \& Johnson. - Belka et al., fig. 4, table 1, pl. 2, fig. 7.

? 1999 Polygnathus kitabicus Yolkin, Weddige, Izokh \& Erina. - Belka et al., fig. 4, table 1.
*? 2014 Polyganthus settedabanicus sp. nov.; Baranov, Slavík \& Blodgett, p. 672, fig. 14h-j.

e.p. 2014 Polygnathus excavatus Carls \& Gandl. - Baranov, Slavík \& Blodgett, p. 662, figs 9d, e, 11e-j, m-q, 15a (only) [figs k, 1 resemble Eoc. juferevi].

Discussion. - Yolkin et al. (1994, pp. 150-151) established an extended list of figured specimens of excavatus in conodont papers. Although we do not always agree with the view of these authors we will not include here another long synonymy list. Bardashev et al. (2002) published two synonymy lists for Eo. excavatus because they recognized alpha and beta morphotypes, which is not followed here.

In order to improve the lower Emsian conodont stratigraphy, it is best to restrict the use of polygnathid taxa to forms close to their type populations and/or to recognize the distribution of clearly defined morphotypes in time and space. Eol. gronbergi and excavatus share in a restricted sense a short free blade, a narrow anterior platform with regular transverse costae, upturned margins, distinctive adcarinal furrows, an asymmetric curvature with slightly wider outer than inner platform, and a subtriangular posterior platform with partly interrupted or semi-crossed lingua. The basal cavity is large and anteriorly constricted. As emphasized by Klapper \& Johnson (1975), its posterior end is inverted in gronbergi, not in excavatus, but there are transitional forms. Eol. excavatus has been synonymized by many authors with Eol. dehiscens (Philip \& Jackson, 1967), which, however, is distinguished by a reduced ornament, forming wide and smooth adcarinal furrows, and a well-developed lingua (see re-illustrations in Mawson 1995). Bultynck (1989) used slight differences of the basal pit for a distinction only at subspecies level. The NE Asian Eol. michaelmurphyi (Baranov, Slavík \& Blodgett, 2014) is morphologically intermediate between Eol. excavatus and Eol. dehiscens, because it combines the ornamented anterior platform of the first with the long lingua and short carina of the second species.

Yolkin et al. (1994) separated excavatus and gronbergi only at subspecies level and, without comment on the aboral morphology, used for the Zinzilban material the interruption of the lingua (excavatus excavatus) or the presence of a "semicrossed lingua" (in supposed excavatus gronbergi) to separate both. Carls \& Valenzuela-Ríos

Figure 5. Conodonts from the "Pragian Limestone" and lower Deiroceras Limestone of Jebel Ihrs; A-E - upper Pragian celtibericus Zone or local lower Belodella Ecozone; F-Q-Bed 16a, lower excavatus M114 Zone or bilatericrescens gracilis Zone. • A - Bel. resima (Philip, 1965). B9.A-5.1, $\times 85$, Bed 2, denticulation not preserved (compare Telford 1975, fig. 14). B - Bel. triangularis (Stauffer, 1940). B9.A-5.2, $\times$ 90, Bed 2. • C, D - Caud. celtibericus (Carls \& Gandl, 1969). Two specimens showing the intraspecific variability; C - B9.A-5.3, × 95, Bed 4; D - B9.A-5.4, × 100, Bed 4. - E - Bel. triangularis (Stauffer, 1940). B9.A-5.5, × 65, Bed 10, denticulation not preserved (compare Sorentino 1989, pl. 8, fig. 8). - F - Caud. sigmoidalis (Carls \& Gandl, 1969). B9.A-5.118, $\times 50 . \bullet \mathrm{G}-$ Lat. bilatericrescens gracilis Bultynck, 1985. Outer process broken off, B9.A-5.119, $\times 75$. - H - Lat. bilatericrescens gracilis Bultynck, 1985. Transitional to multicostatus, denticles not isolated, posterior end broken off, B9.A-5.120, $\times 75$. -I - Crit. miae (Bultynck, 1971). B9.A-5.121, × 100. • J-M - Eol. excavatus (Carls \& Gandl, 1969) s. str.; J, K - "Morphotype beta", B9.A-5.122, × 60; L, M - B9.A-5.123, × 65. - N-Q - Eol. excavatus (Carls \& Gandl, 1969) Morphotype 114; N, O - B9.A-5.124; P, Q - B9.A-5.125; both × 60. 

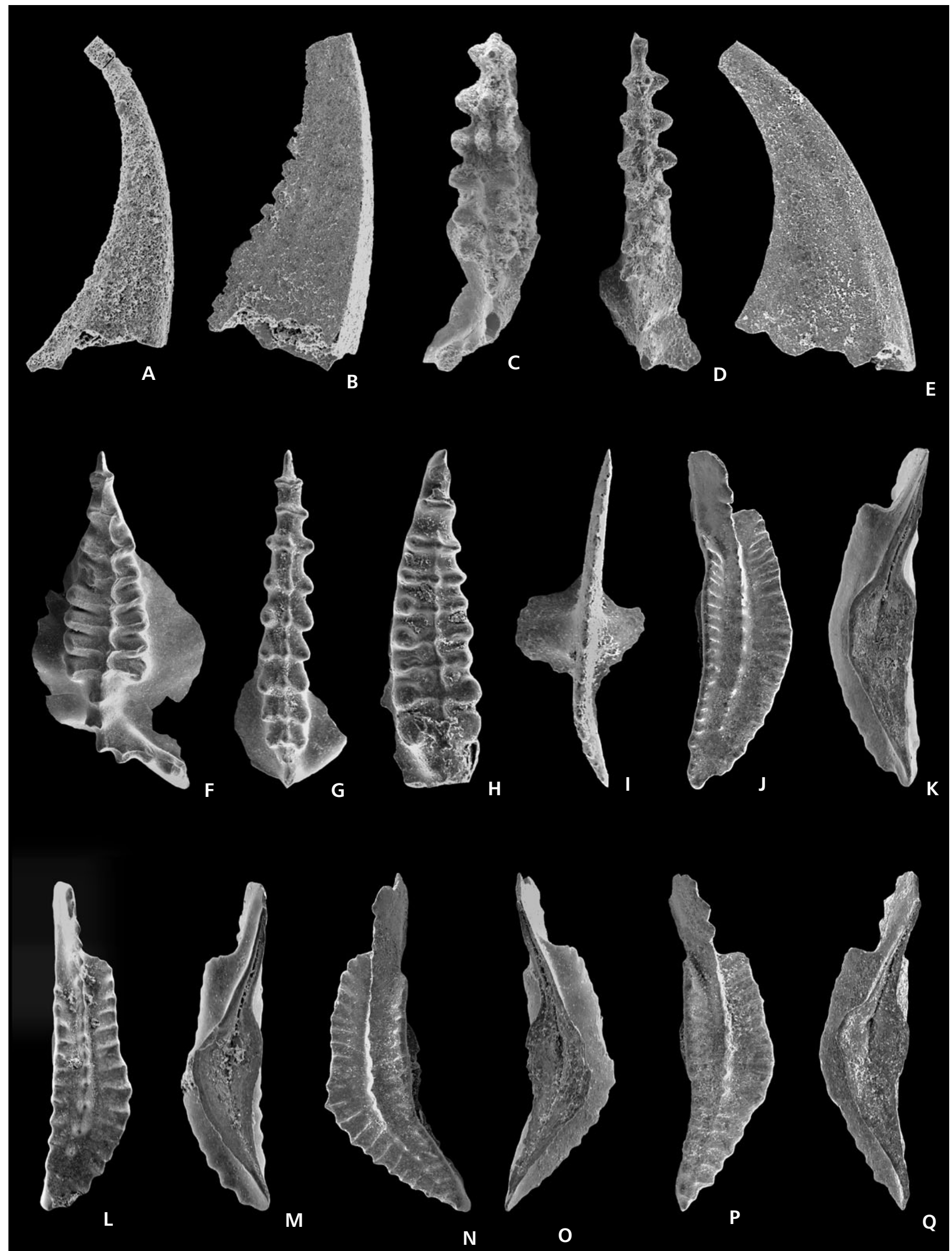
(2002) and Carls et al. (2009) regarded forms with excavatus-type (non-inverted) basal cavity and a "semicrossed lingua" as a distinctive morphotype or subspecies, excavatus 114 or excavatus ssp. 114. They advocated to use this form in future to define the base of the Emsian. This requires a look at the types of Eol. excavatus. The original illustrations by Carls \& Gandl (1969) and the slightly different photos in Klapper \& Johnson (1975) clearly show that in the holotype of Po. excavatus the posterior transverse ridges are interrupted only on the outer platform, leaving an inner platform with the habitus of a "semi-crossed" lingua. In one of the paratypes (Carls \& Gandl 1969, pl. 18, fig. 10), the posterior transverse ridges are interrupted only on the inner platform, whilst a well-developed, slightly "semi-crossed lingua" characterizes the specimen of pl. 18, fig. 12. The identification of excavatus specimens as Morphotype 114 requires that the lingua is not interrupted at all. The differences to the holotype are very subtle and forms with partly interrupted (excavatus $\mathrm{s}$. str.) or "semi-crossed" lingua occur together within wellpreserved excavatus population from Jebel Ihrs (Bed 16a, Fig. 5J-Q, Bed 16c, Fig. 7C-H) and El Khraouia (Bed 15f). This speaks against a formal taxonomic separation of Morphotype 114. Some justification for a subspecies distinction could come from the different distributions in time and space, which may indicate that Morphotype 114 represents a later, minor genpool expansion, a chronosubspecies.

Another excavatus paratype figured by Carls \& Gandl (1969, pl. 18, fig. 13) has a shortened carina that is terminated by continuing, deep adcarinal furrows, which also fully interrupt the transverse ridges. This specimen has been separated in Bardashev et al. (2002) as "Morphotype $\beta$ " and conforms to their definition of Eocostapolygnathus. One of our specimens from the lower Deiroceras Limestone of Jebel Ihrs (Fig. 5J, K) approaches the same morphology, also with respect to a slight narrowing of the anterior inner platform. Currently we do not separate such specimens beyond the morphotype level.

Lower Emsian polygnathids with a strong carina that extends slightly beyond the posterior platform end (e.g., Klapper \& Johnson 1975, pl. 1, figs 5, 6, 13, 14) fall in Eoc. lenzi Klapper, 1969 in the strict sense of its holotype (see synonymy in Bardashev et al. 2002). As noted by Murphy (2002), but contrary to the proposal in Klapper \& Johnson
(1975), Eoc. lenzi is not identical with Eol. excavatus or Eol. dehiscens. In the system of Bardashev et al. (2002) it is not even congeneric with both. The absence of lenzi- and dehiscens-type polygnathids from our excavatus populations from several localities supports the view that they represent distinctive taxa with a different distribution.

Eol. perbonus (= foveolatus Philip \& Jackson, 1967, name of Pa element) is based on the type specimens of Philip (1966) and Philip \& Jackson (1967). It differs from Eol. excavatus in its shortened carina, complete lingua, and a stronger curvature of the platform. The posterior tip of the basal cavity may be slightly inverted but the lower surface of the foveolatus holotype was never figured. Eolinguipolygnathus perbonus $\mathrm{s}$. str. is morphologically closer to Eol. dehiscens than to Eol. excavatus or Eol. gronbergi. It should include the Victoria form illustrated by Mawson (1987a, pl. 32, figs 6-10) as transitional between Eol. dehiscens and Eol. nothoperbonus, but not her polygnathids with less (pl. 34, figs 10, $11=$ excavatus Morphotype 114) or more advanced basal cavity (pl. 34, figs 12, 13; close to her Eol. labiosus). In Victoria there is a complete transition from perbonus to nothoperbonus (see specimens of Klapper \& Johnson 1975 and Mawson 1987a). Typical representatives of Eol. perbonus were documented by Mawson \& Talent (2003) also from Queensland. But the species is apparently absent from North Africa. Polygnathus yakutensis Baranov, Slavík \& Blodgett, 2014 is here regarded as a subjective synonym of Eol. perbonus.

In the excavatus material from Bed 16a of Jebel Ihrs there are a few specimens with an only very weak interruption of the posterior carina. They are intermediate to Morphotype 114 representatives from the same bed (Fig. 5N-Q). The latter show some transition to early, narrow morphotypes of Eol. radula sp. nov. (Fig. 6I-L). In addition, there are specimens that combine regular transverse ribs and a moderately curved platform with a rather well defined row of posterior carina nodes (Fig. 6C, D). This "Morphotype JI16a" is somewhat intermediate to Eocostapolygnathus. It may include the kitabicus record from the Deiroceras Limestone of Belka et al. (1999), which has not been illustrated. A specimen with a similar, fine carina but more posterior bending of the platform was illustrated as Po. excavatus by Baranov et al. (2014, figs 9D, E).

Figure 6. Conodonts from the Deiroceras Limestone of Jebel Ihrs (western Tafilalt); A-L - Bed 16a; M-R - Bed 16c; all lower Emsian, excavatus M114 Zone. • A, B - Eol. radula sp. nov. Early wide form, B9.A-5.126, × 60. • C, D - Eol. excavatus (Carls \& Gandl, 1969) Morphotype JI16a. With fine but distinctive posterior carina, B9.A-5.127, $\times 60 . \bullet$ E, F - Eol. radula sp. nov. Early form with basal cavity that is wider than the upper platform, paratype B9.A-5.128, × 40. • G, H - Eol. pannonicus (Mashkova \& Apekina, 1980). With typical oblique ridge of left anterior platform, B9.A-5.129, $\times 60$. - I, J - Eol. radula sp. nov. Early narrow form, slightly transitional to Eol. excavatus Morphotype 114, B9.A-5.130, × 60. • K, L-Eol. excavatus (Carls \& Gandl, 1969) Morphotype 114. Slightly transitional to Eol. radula sp. nov., B9.A-5.131, 40. • M - Eol. radula sp. nov. Slightly transitional to Eol. excavatus Morphotype 114, B9.A-5.6, × 60. • N-P - Eol. radula sp. nov.; N - paratype B9.A-5.7, × 60; O - paratype B9.A-5.8, × 75; P - paratype B9.A.5-9, $\times 50$. $・$ Q, R - Eol. radula sp. nov. Holotype B9.A-5.10, $\times 60$. 

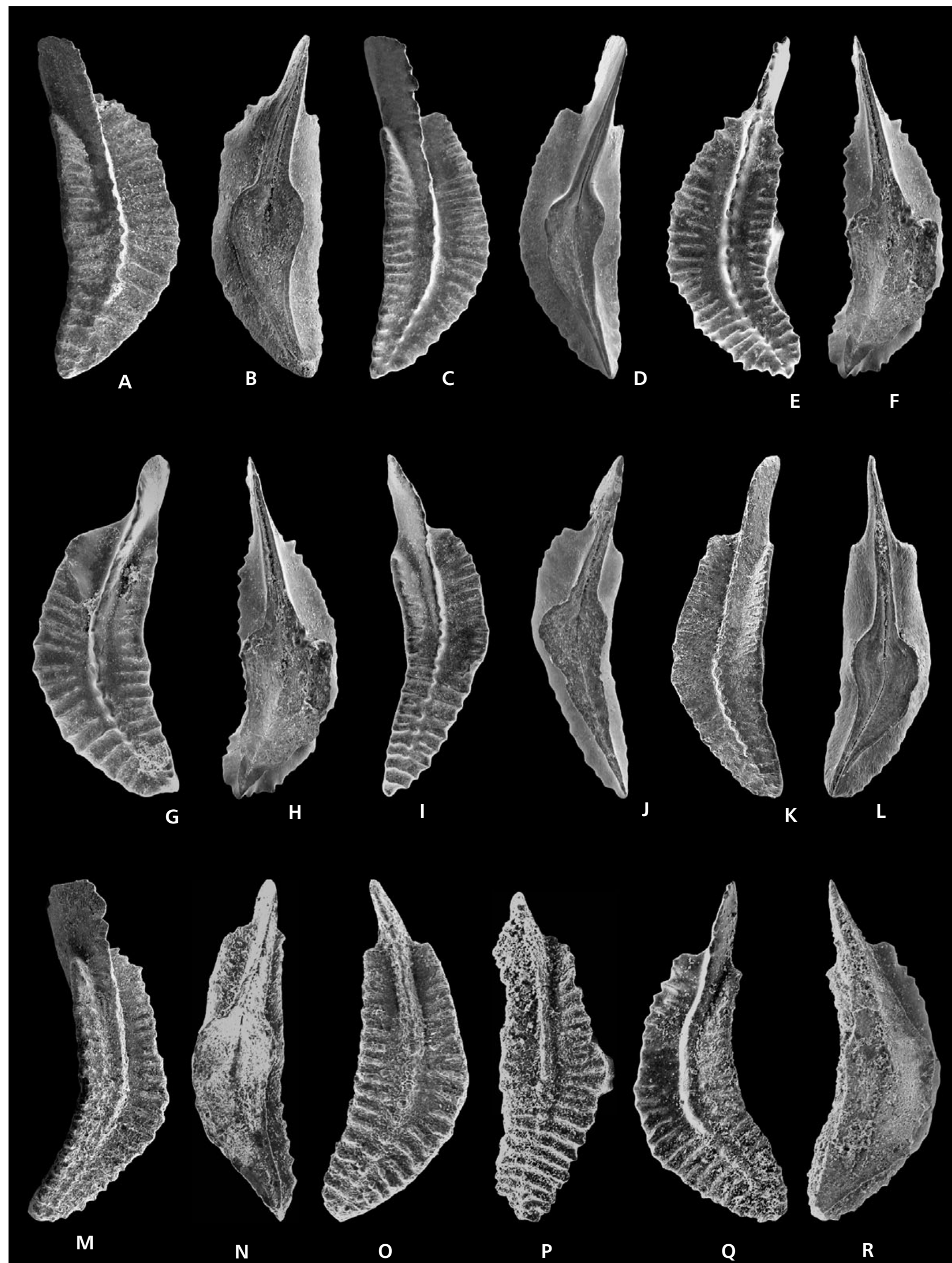
Four specimens from Sample BTW1, at the top of the Deiroceras Limestone, are illustrated in Fig. 15. They show a large basal cavity, covering the major part of the lower side of the platform. In the posterior part the cavity becomes very narrow, but showing still a deep slit. In specimen b6594 (Fig. 15C, D) this slit is flattened. In the four specimens the ornamentation of the oral side consists of short ribs on the major part of the platform while ribs on the tongue are interrupted by small nodes. The only difference to the type material of Eol. excavatus is that the inward bowing of the tongue is situated more posteriorly and that it is more angular. This feature applies to the majority of our specimens, including representatives of Morphotype 114 (for exceptions see Fig. 5J, P, Q). In this way, there are transitions towards Po. ramoni Martínez-Pérez \& Valenzuela-Ríos, 2014, which type series includes specimens with semi-crossed (the holotype) or interrupted lingua (all figured paratypes). Our excavatus specimen of Fig. 5L, M resembles the ramoni paratype MGUV 21.027 (their fig. 8k), the specimen of Fig. 15C, D the ramoni paratype 21.024 (their fig. 8i), and our specimen from Fig. 7E, F is another intermediate form. We propose to restrict Eol. ramoni, perhaps as a subspecies, to forms with both a slightly widened, well-rounded outer posterior platform and reduced anterior platform ornament. The latter feature resembles Eol. dehiscens. There are also intermediates towards ramoni in the excavatus populations of Far East Russia illustrated by Baranov et al. (2014).

Eol. carlsi (Martínez-Pérez \& Valenzuela-Ríos, 2014) is closely related to Eol. excavatus but characterized by a narrow and concave outer posterior platform margin. Such forms do not occur in our populations, which supports their distinction. The holotype of Eol. settedabanicus (Baranov, Slavík \& Blodgett, 2014) resembles excavatus Morphotype 114 but it has a slightly extended outer platform and the basal cavity is narrower than in the Spanish forms, than in typical NE Siberian excavatus, or than in our specimens, producing a spine-like, slitted posterior ridge without inversion. This form, which was based on two specimens, may be regarded as a subspecies or morphotype within Eol. excavatus but we would hesitate to use the name for our M114 specimens.
A specimen from Jebel Ihrs identified by Becker \& Aboussalam (2011, figs 6.6 and 6.11) as Eoc. aff. gronbergi displays an elongated, shallow basal cavity that tapers rather gradually under the anterior platform. Its posterior tip is intermediate between Eol. excavatus and gronbergi (compare intermediate specimens illustrated in Klapper \& Johnson 1975). This form, included here as a variant in Eol. excavatus Morphotype 114, resembles to some extent Eol. abyssus (Mawson, 1987a), which has a deeper basal cavity with V-shaped cross-section.

Geographic range. - Pan(sub)tropical, from Nevada and northern Gondwana to Australia.

Stratigraphic range. - The species defines the excavatus Zone and is mostly restricted to it. A single fragmentary specimen from the basal Akhal Tergoua Member of the western Dra Valley is associated with Lat. beckmanni, which suggests a rare upper range into equivalents of the higher gronbergi Zone (lower catharinae Subzone). This is supported by an overlap of the typical morphotype in NE Siberia with Eol. perbonus (Baranov et al. 2014).

\section{Eolinguipolygnathus radula \\ Aboussalam \& Becker sp. nov.}

Figures 6A, B, E, F, I, J, M-R, 21C

2011 Eocostapolygnathus aff. pannonicus Mashkova \& Apekina. - Becker \& Aboussalam, p. 38, figs 5.11-5.16, 6.1.

2013 Eolinguipolygnathus sp. nov. aff. pannonicus Mashkova \& Apekina. - Aboussalam \& Becker, p. 138, figs $7.9-11$.

Derivation of name. - From the Latin radula $=$ rasp, because of the strongly and regularly ribbed ornament.

Types. - Holotype B9.A-5.10, Becker \& Aboussalam (2011), fig. 5.15, 5.16, here re-illustrated in Fig. 6Q, R; paratypes B9.A-5.6-9, 56, 128.

Type level and locality. - Upper part of Deiroceras

Figure 7. Conodonts from the upper Deiroceras Limestone of Jebel Ihrs, lower Emsian; A-K - Bed 16c, excavatus Morphotype 114 Zone; L-Q - Bed 16d, bilatericrescens bilatericrescens Zone. • A, B - Lat. bilatericrescens bilatericrescens (Ziegler, 1956). Intermediate from bilatericrescens gracilis Bultynck, 1985, B9.A-5.11-12, × 60. • C, D - Eol. excavatus (Carls \& Gandl, 1969) Morphotype 114; C - upper view of B9.A-5.13; D - lower view of B9.A-5.14; both $\times 75$. E , F - Eol. excavatus (Carls \& Gandl, 1969) s. str.; E - upper view of a specimen with strongly upturned outer anterior platform margin, B9.A-5.15, $\times 45 ; \mathrm{F}-$ lower view of specimens with wide basal cavity that flattens at the posterior tip, B9.A-5.16, $\times 75$. $\bullet$ G, H - Eol. excavatus (Carls \& Gandl, 1969) Morphotype 114. With rather gradually tapering anterior basal cavity, slightly resembling Eol. abyssus (Mawson, 1987a), B9.A-5.17, × 85. • I - Lat. bilatericrescens multicostatus (Carls \& Gandl, 1969). B9.A-5.24, × 50. • J, K - Crit. miae (Bultynck, 1971); J - upper view of B9.A-5.27, $-60 ; \mathrm{K}-$ lower view of B9.A-5.28, $\times 60$. $\bullet \mathrm{L}-$ Caud. celtibericus (Carls \& Gandl, 1969). B9.A-5.132, $\times 85$. $・$ M - Lat. bilatericrescens multicostatus (Carls \& Gandl, 1969). B9.A-5.133, × 60. $\bullet$, O - Eol. excavatus (Carls \& Gandl, 1969) Morphotype 114. B9.A-5.134, × 65. • P, Q-Eol. excavatus (Carls \& Gandl, 1969). Specimen with very short carina; therefore, transitional to Eol. perbonus, B9.A-5.135, $\times 60$. 


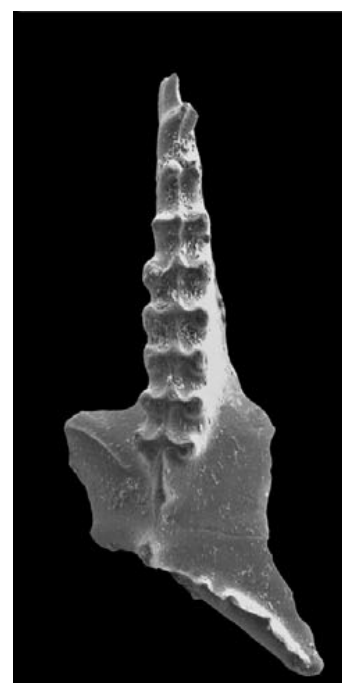

A
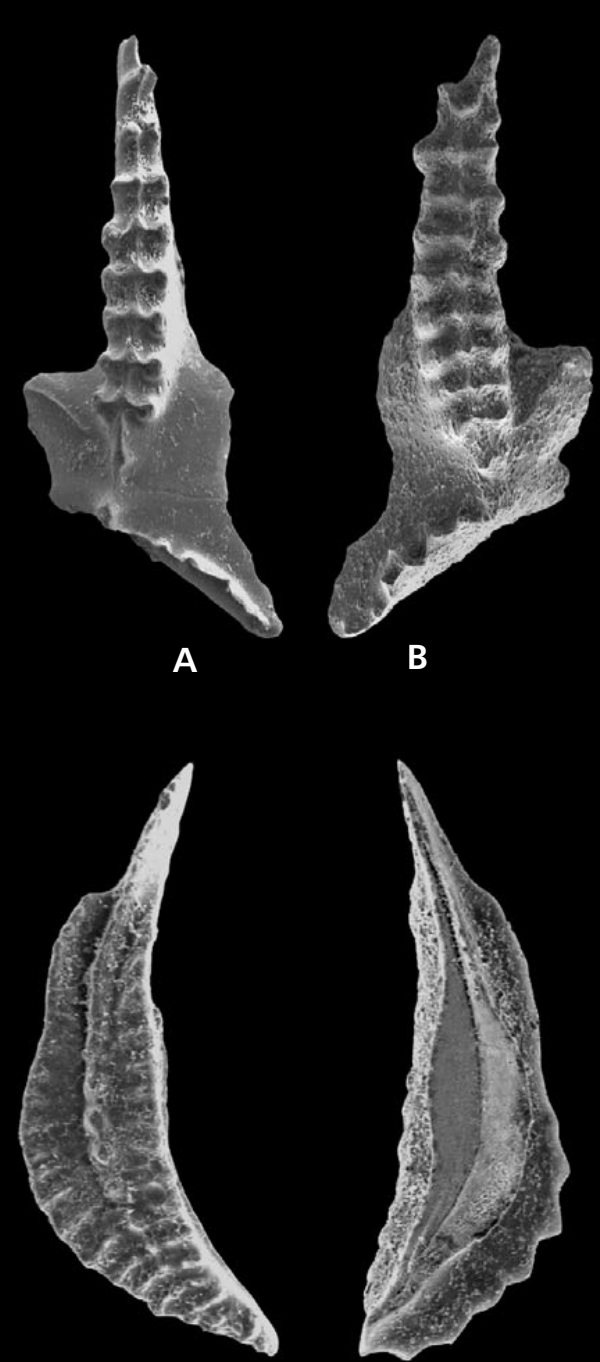

G
B

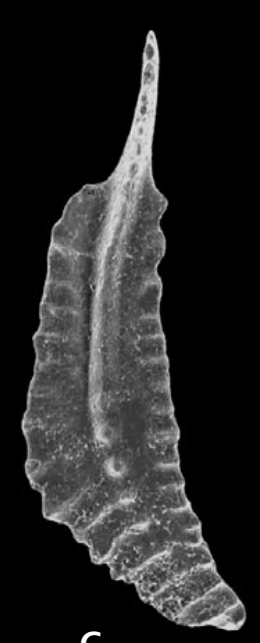

C

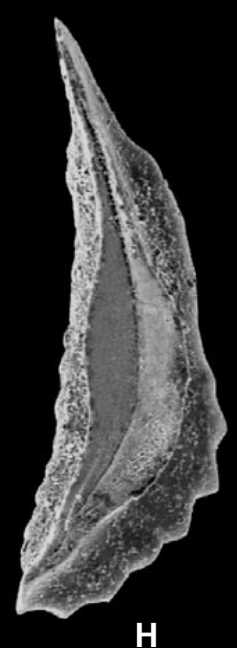

H
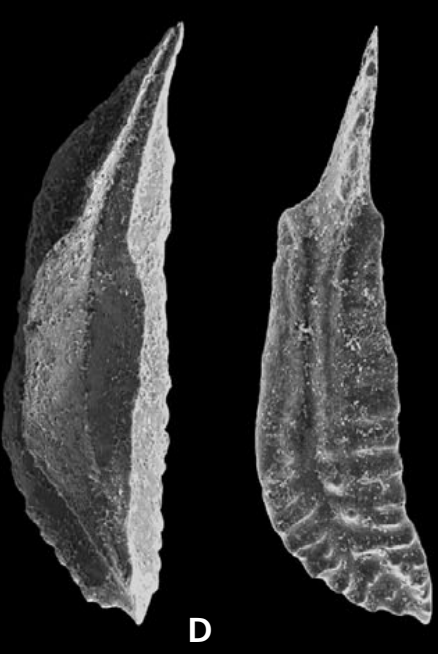

E
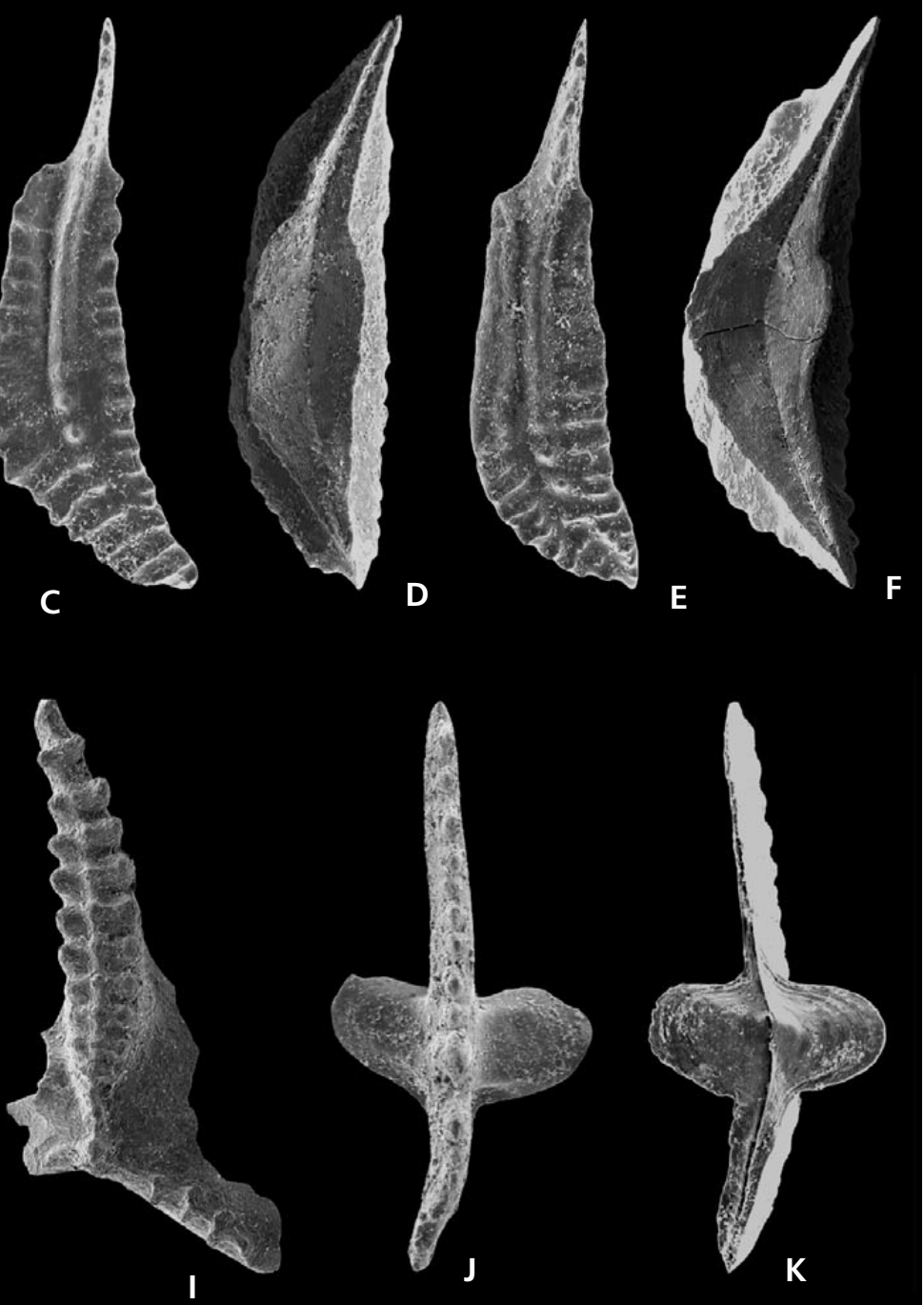

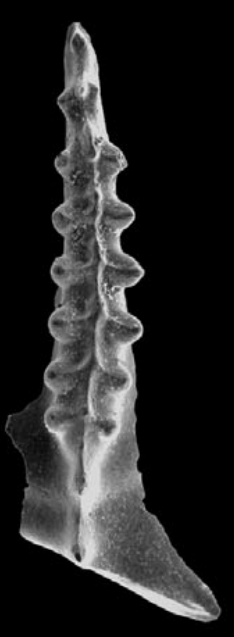

L

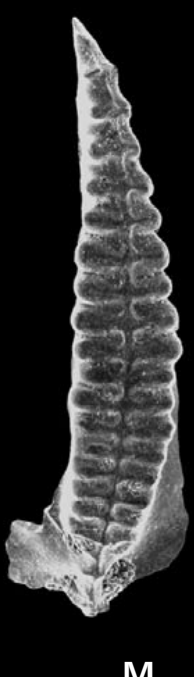

M

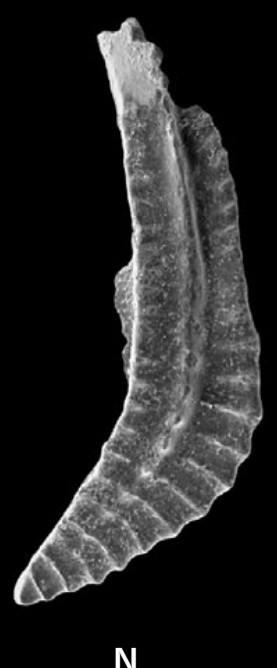

$\mathbf{N}$

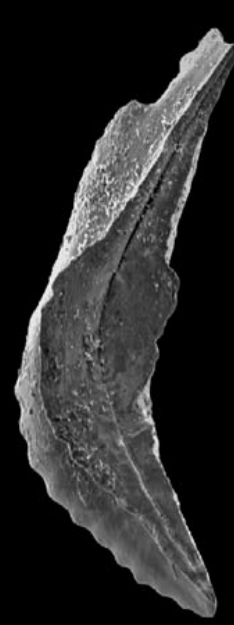

0

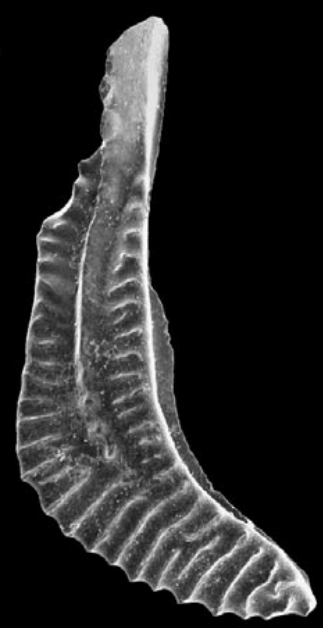

P

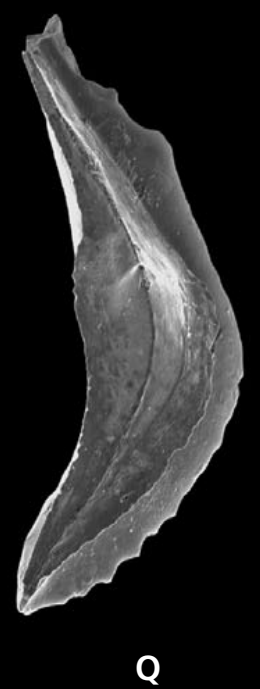


Limestone (Bed 16c), upper part of excavatus Morphotype 114 Zone, lower Emsian, Jebel Ihrs.

Diagnosis. - Free blade very short (less than $20 \%$ of total length), platform markedly curved, moderately narrow, flat, with weak adcarinal furrows in the anterior third, and regular, straight to radial transverse ridges that form a long "semicrossed lingua" with rounded posterior end. Basal cavity large, occupying most of the aboral platform area, very shallow to flat but not inverted at the posterior end.

Description. - Early morphotypes from the lower Deiroceras Limestone (Jebel Ihrs, Bed 16a) partly still resemble Eol. excavatus M114 because they have relatively narrow platforms (Fig. 6I, J) or their anterior margins are not yet flat but slightly bent outwards (Fig. 6A, B). The basal cavities are large and sometimes wider than the platform, occasionally with secondary small marginal constrictions, which gives a "labiose pattern" (Fig. 6F). The posterior end is narrow, not yet wide tongue-shaped.

In the type material from Bed 16c of Jebel Ihrs there is some intraspecific variability of Eol. radula sp. nov. concerning platform width and curvature. The basal cavities are large (Fig. 6N) or very large (holotype, Fig. 6R), the name-giving, rib-like ornament is very regular, and the semi-crossed lingua is weakly (Fig. 6P) or well (Fig. 6O) developed. B9.A-5.6 (Fig. 6M) is a narrow form that is still slightly transitional from Eol. excavatus M114.

Discussion. - As noted above, the main difference from Eol. excavatus is the flat platform, lack of deep adcarinal grooves, especially in the anterior half, and the very regular ribbing. The early morphotypes differ from associated Eol. pannonicus by the lack of the characteristic, oblique anterior ridge (see Fig. 6G, H) of the latter, which forms a distinctive, smooth anterior platform corner. Eol. pannonicus, including Eoc. yolkini Bardashev, Weddige \& Ziegler, 2002, is generally a variable species. A few of the Siberian specimens figured by Izokh et al. (2011, especially pl. III, fig. 15a, b) show a similar platform shape and ribbing as in Eol. radula sp. nov. The supposed youngest representative of Eol. pannonicus from the basal nothoperbonus Zone of the Central Pyrenees (Martínez-Pérez \& Valenzuela-Ríos 2014, fig. 9i), resembles Eol. radula sp. nov. but has a wider platform with rounded posterior outer extension, and a shorter carina. Specimens illustrated by Yolkin et al. (2008) as Po. "postpannocus" nom. nud. and as Po. foveolatus in Izokh et al. (2011a) all differ in their narrow und upturned anterior platforms and semi-crossed linguae. Half of them lack a posterior cavity inversion and fall in excavatus M114, the others with an inverted tip should be placed in Eol. gronbergi.

Eol. karsteni (Baranov, Slavík \& Blodgett, 2014) from younger strata (gronbergi Zone) of the Russian Far East differs from our new form by the regular presence of nodes and small spines on the transverse costae. The Spanish Eol. ramoni lacks regular anterior platform ornament; Eol. carlsi is much narrower with a concave outer posterior margin. The platform outline is very different, with a reduced lingua, in the group of Eol. arthuri (Baranov, Slavík \& Blodgett, 2014) and Eol. rarus (Aksenova, 1987). Eol. perbonus (=foveolatus) has deep adcarinal furrows and upturned platform margins, especially in the anterior third, a less extensive basal cavity, and a fully developed (not semi-crossed) lingua. Eol. abyssus (Mawson, 1987a) is additionally characterized by a deeper, V-shaped (in cross-section) basal cavity. Typical Eol. gronbergi combine the excavatus-type platform with an inversion of the posterior part of the basal cavity. All other, younger species of Eolinguipolygnathus share the latter feature.

In a more conservative approach our new form may be recognized at subspecies level. Its distinction is emphasized by the fact that it has not been illustrated from the many other regions with Eol. excavatus.

Geographic distribution. - Only known from the Tafilalt (Jebel Ihrs, El Khraouia).

Stratigraphic range. - Restricted to the Deiroceras Limestone (excavatus M114 Zone).

\section{Eolinguipolygnathus gronbergi \\ (Klapper \& Johnson, 1975)}

$c f$. Figure 22F, G

*e.p. 1975 Polygnathus gronbergi sp. nov.; Klapper \& Johnson, p. 73, pl. 1, figs 17-24, 27-28 [figs 25, 26 transitional to L. gilberti].

Figure 8. Conodonts from the Anetoceras Limestone of Jebel Ihrs; A-C-Bed 18b, bilatericrescens bilatericrescens Zone; D-I - Bed 20b, latus Zone; J-M - Bed 21a, latus or basal steinhornensis Zone; N - Bed 22b, higher latus or catharinae Subzone. • A - Lat. bilatericrescens multicostatus (Carls \& Gandl, 1969). Small specimen, B9.A-5.23, × 120. • B-E - Lat. bilatericrescens bilatericrescens (Ziegler, 1956). Showing the intraspecific variability; B - B9.A-5.25, × 85; C - B9.A-5.26, × 75; D - form with widened basal cavity, B9.A.5-29, × 65; E - B9.A5-30, × 65. • F-H - Lat. bilatericrescens multicostatus (Carls \& Gandl, 1969). Three different morphotypes; F - transitional specimen towards the nominate subspecies, with long posterior end of the spindle, B9.A-5.31, $\times 55 ; \mathrm{G}-$ advanced morphotype with almost double-rowed outer posterior process, B9.A-5.32, $\times 45$; H - typical specimen, B9.A-5.33, $\times 55$. $・$ I - Lat. latus (Al-Rawi, 1977). B9.A-5.35, $\times 75$. $・$ J - Lat. armoricanus Bultynck, 1989. B9.A-5.136, $\times 65$. $\bullet$ K - Crit. steinhornensis (Ziegler, 1956). B9.A-5.137, × 85. • L, M - Eoc. juferevi (Aksenova, 1987). Specimen closely resembling one of the paratypes, B9.A-5.138, $\times 85$. - N - Lat. beckmanni sinuatus (Klapper, Ziegler \& Mashkova, 1978). B9.A-5.37, × 45. 


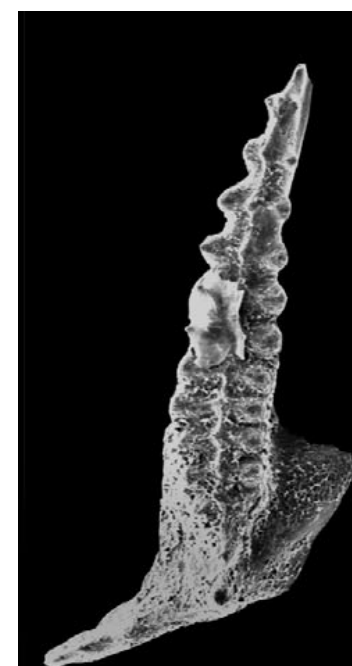

A

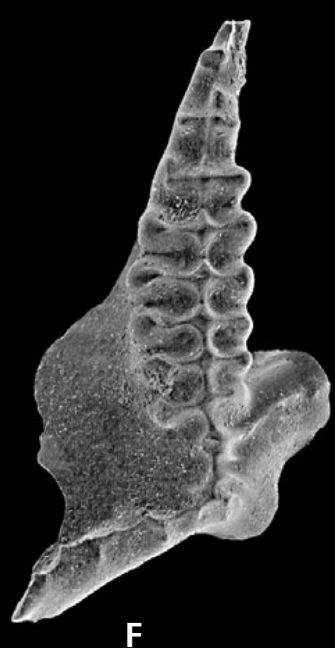

F

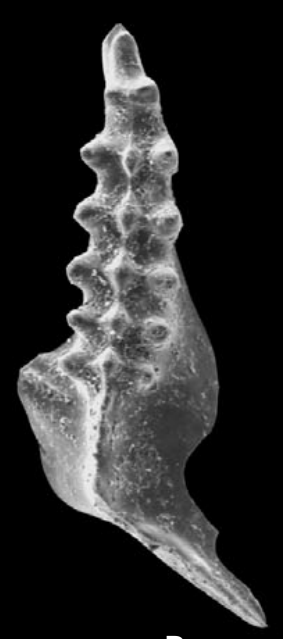

B

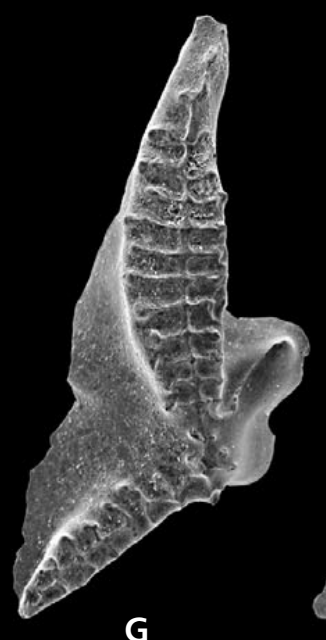

G

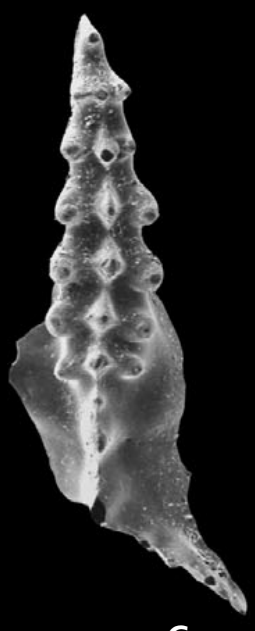

C

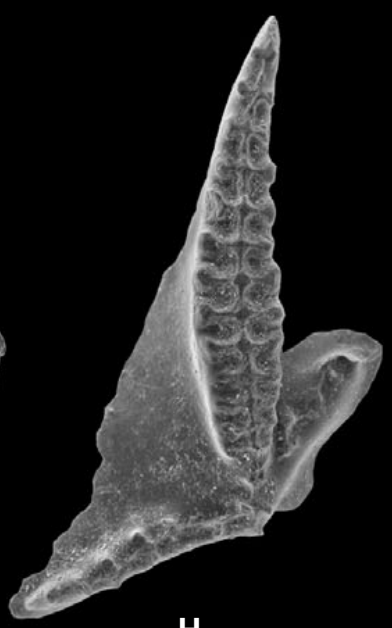

H
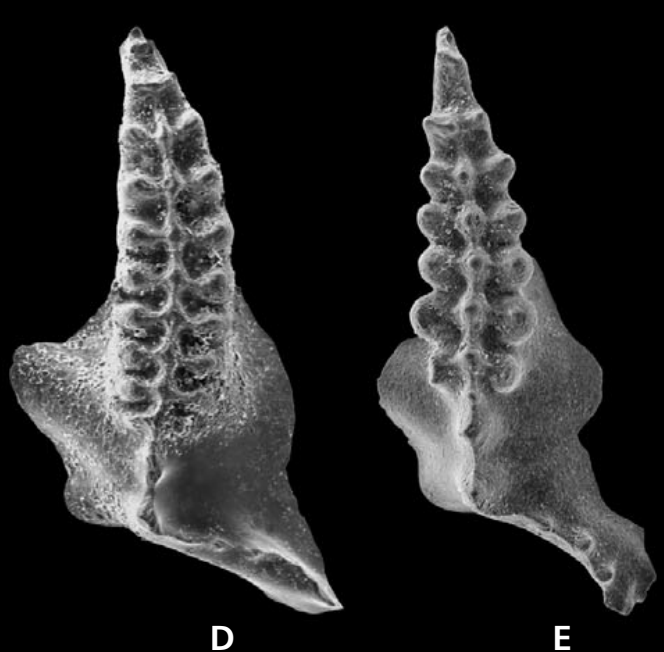

E

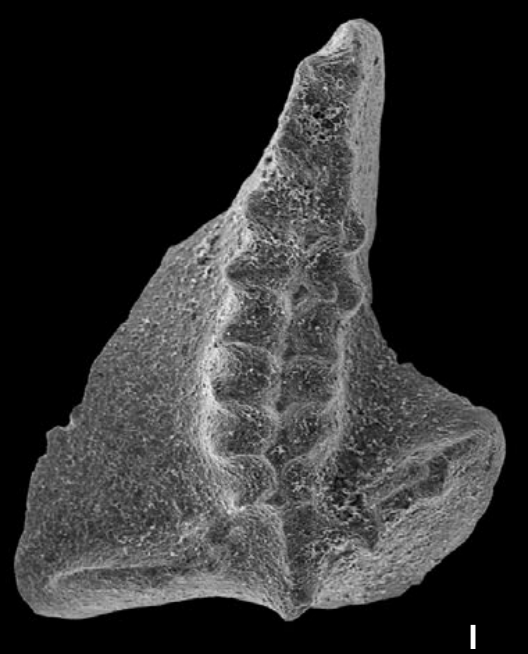

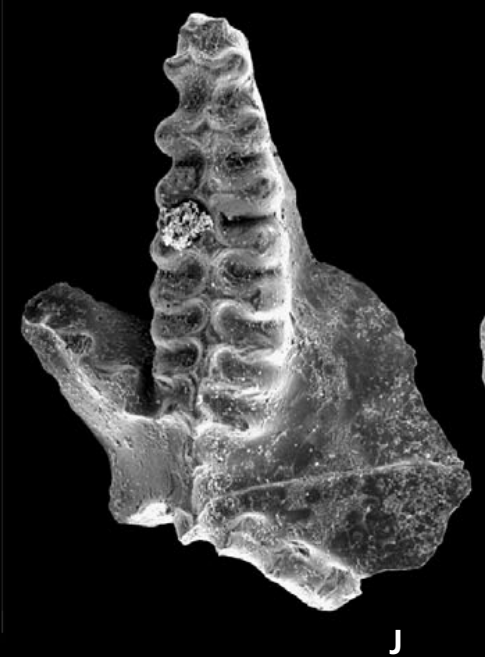

J

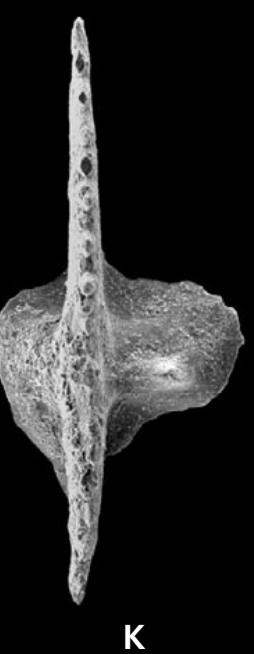

K

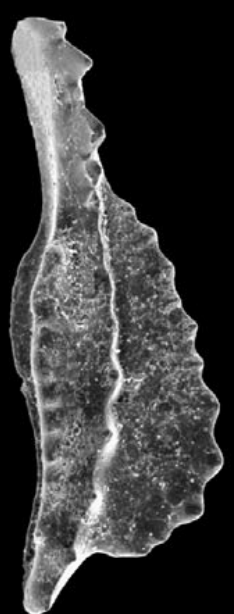

L

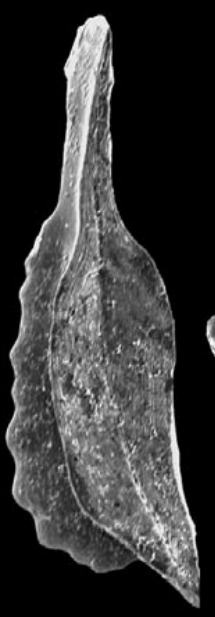

M

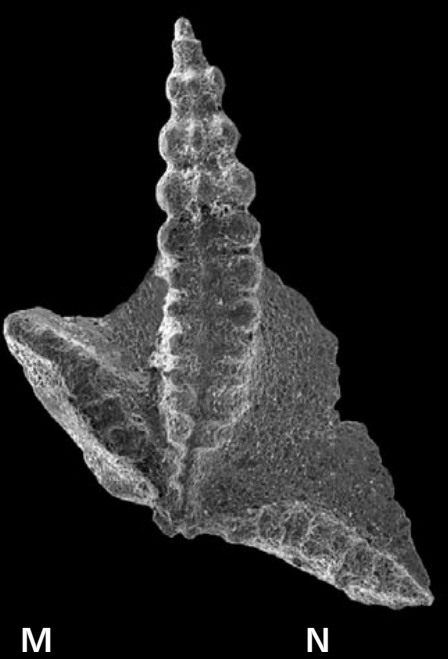


1980 Polygnathus gronbergi Klapper \& Johnson. - Bultynck \& Hollard, p. 26, pl. II, fig. 6a, b, ?fig. 7a-c.

non 1985 Polygnathus gronbergi Klapper \& Johnson. - Bultynck, fig. 4, pl. 5, fig. 16 [= Eol. juferevi; see Bardashev et al. 2002].

non 1999 Polygnathus gronbergi Klapper \& Johnson. - Belka et al., fig. 4, table 1, pl. 2, fig. 7 [= Eol. excavatus].

*e.p. 2002 Eocostapolygnathus philipi sp. nov.; Bardashev, Weddige \& Ziegler, p. 405 (only the holotype).

*e.p. 2002 Eocostapolygnathus polinae sp. nov.; Bardashev, Weddige \& Ziegler, pp. 405-406 (only the holotype).

*e.p. 2008 Polygnathus "postpannonicus"; Yolkin, Weddige, Izokh \& Erina in Yolkin et al. (eds), pp. 92-94, pl. 3, figs 11,12 (only).

*e.p. 2011 Polygnathus luciae sp. nov.; Martínez-Pérez \& Valenzuela-Ríos, figs 7a-b2 (only).

e.p. 2011a Polygnathus foveolatus Philip \& Jackson. - Izokh, Yolkin, Weddige, Erina \& Valenzuela-Ríos, pp. 54-55, pl. III, figs 23, 23 (only).

Discussion. - The type material of Eol. gronbergi shows a "semi-crossed lingua" and large basal cavity with a marked constriction under the anterior platform. Based on the amount of posterior basal cavity inversion, Bultynck (1989) introduced $\alpha$ and $\beta$ morphotypes, which are both present among the Nevada originals (see Klapper \& Johnson 1975, pl. 1). Bardashev et al. (2002) adopted Bultynck's distinction. Eocostapolygnathus philipi Bardashev, Weddige \& Ziegler, 2002 and Eoc. polinae Bardashev, Weddige \& Ziegler, 2002 are regarded as variants of Eol. gronbergi. The second shows a stronger basal cavity inversion than the first. Eolinguipolygnathus gagievi Bardashev, Weddige \& Ziegler, 2002 differs in an extended outer posterior platform and better-developed lingua, similar as in Eol. perbonus. Baranov et al. (2014) introduced a new Morphotype gamma based on specimens with rather strong inversion, long semi-crossed lingua, and peculiar additional nodes and spines on the oral surface; this distinctive form could well represent a new taxon.

The gronbergi specimen from Sample BTW4 (upper Anetoceras Limestone, figured in Bultynck \& Hollard (1980, pl. II, fig. 7a, b), resembles Eoc. lenzi and a
Po. gronbergi figured by Apekina \& Mashkova (1978, pl. 75, fig. 6, 6a), which Bardashev et al. (2002) placed in their Eoct. richi.

The gronbergi specimen illustrated by Belka et al. (1999) from the lower Deiroceras Limestone of Ouidane Chebbi does not really show an inverted posterior basal cavity and is regarded as an Eol. excavatus with a slight trend towards Eol. gronbergi. A specimen identified as Eol. cf. gronbergi from the lower Mimagoniatites Limestone of Jebel el-Mrier has an unsually smooth upper surface but it appears to have been abraded (Fig. 19F, G). The absence of deep adcarinal furrows is also remarkable. The posterior basal cavity is markedly inverted, the lingua slightly "semi-crossed". The upper surface resembles a specimen assigned to the Morphotype $\beta$ of Eol. gronbergi by Bultynck (1989, pl. 3, fig. 3a, b). But the flat basal cavity is somewhat larger.

Geographic distribution. - Pan(sub)tropical, from Nevada to Australia.

Stratigraphic range. - Gronbergi Subzone (Lower gronbergi Zone) to inversus Zone.

\section{Eolinguipolygnathus aff. gronbergi (Klapper \& Johnson, 1975) \\ Figure $15 \mathrm{H}-\mathrm{J}$}

Description. - Several specimens from the lower Anetoceras Limestone of sections $\mathrm{BTW}$ and $\mathrm{BTN}$ are characterized by wide and flat, somewhat labiose basal cavities with an inverted posterior tip (Fig. 15I), relatively broad, flat, variably costate platforms, shallow adcarinal furrows, an extension of the outer posterior platform, and a poorly developed, broad tongue (Fig. 15H).

Discussion. - The posterior inversion of the basal cavity conforms to Eol. gronbergi, but the platform is wider and flatter than in that species, especially in the outer corner, which is wider than the inner platform. Similar specimens have been figured by Bultynck (1989, pl. 3, figs 3, 4) as "gronbergi $\beta$ morphotype". Eolinguipolygnathus rarus is

Figure 9. Conodonts from the upper part of the lower Emsian at Jebel Ihrs; A-E - middle Anetoceras Limestone, Bed 22b, catharinae Subzone or lower steinhornensis Zone; F - Bed 27b, upper Mimagoniatites Limestone, local Upper Belodella Ecozone; G-P - Bed 31a 1 , inversus Zone. - A - Lat. beckmanni beckmanni (Ziegler, 1956). Fragmentary, advanced specimen with third, nodose, posterior process, B9.A-5.36, $\times 60$. $\bullet$ B, C - Eol. catharinae (Bultynck, 1989); B - upper view; C - lower view showing the typical extensions of the flat basal cavity, very unlike as in the holotype of Eol. mashkovae (Bardashev, 1986), B9.A-5.34, × 60. • D, E - Crit. steinhornensis (Ziegler, 1956). Two differently asymmetric specimens; D - B9.A-5.38, × 60; E-B9.A-5.39, $\times 65 . \bullet F-$ Lat. bilatericrescens bilatericrescens (Ziegler, 1956). Rare, unfortunately incomplete specimen from the top Anetoceras Limestone, B9.A-5.40, × 85. • G, H - Eol. annamariae (Bultynck, 1989) Morphotype alpha. Somewhat transitional to Eol. nothoperbonus, B9.A-5.139, × 75. -I, J - L. inversus (Klapper \& Johnson, 1975). Small form, B9.A-5.140, ×85. $\bullet$ K-P - Eol. jacksoni (Bardashev, Weddige \& Ziegler, 2002). Three specimens illustrating the ontogenetic and intraspecific variation; K, L - B9.A-5.141, $\times 60 ; \mathrm{M}, \mathrm{N}-\mathrm{B} 9 . \mathrm{A}-5.142, \times 75 ; \mathrm{O}, \mathrm{P}-\mathrm{B} 9 . \mathrm{A}-5.143, \times 85$. 


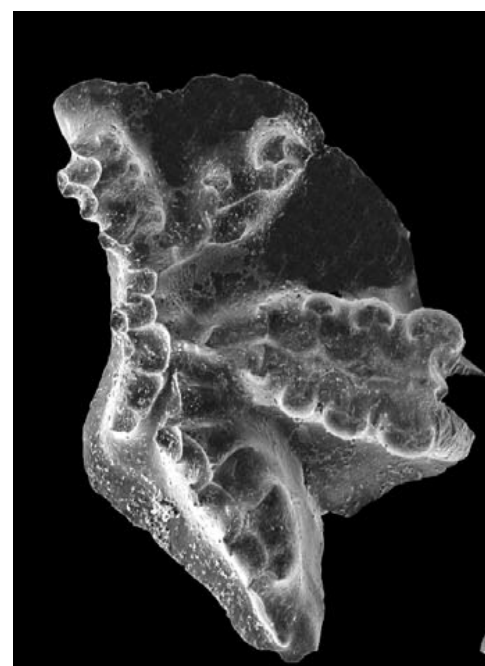

A

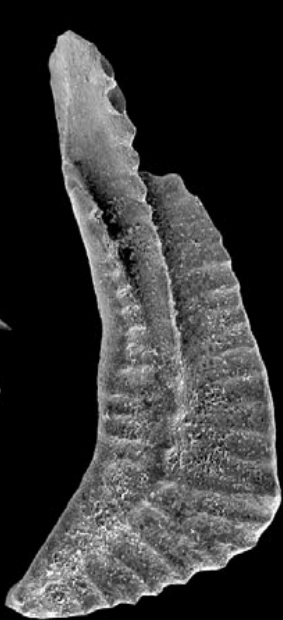

B

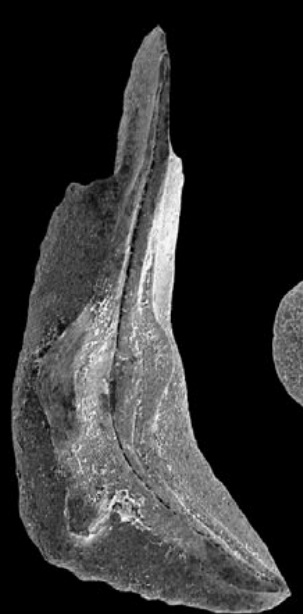

C
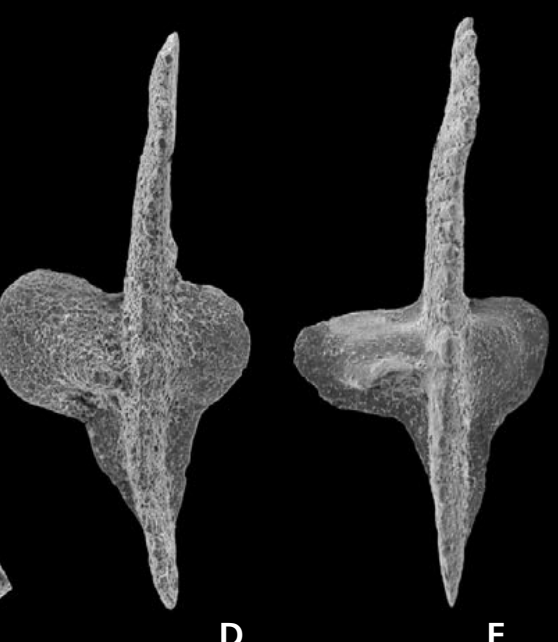

D

$\mathbf{E}$

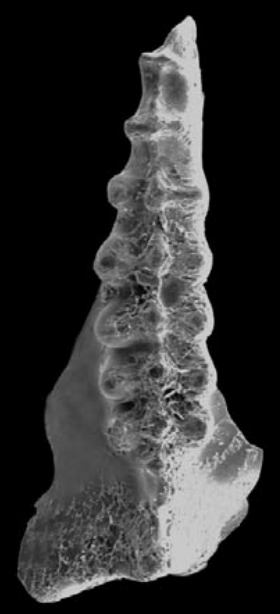

F

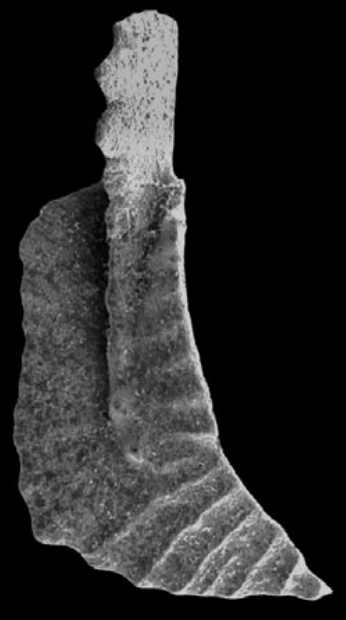

G

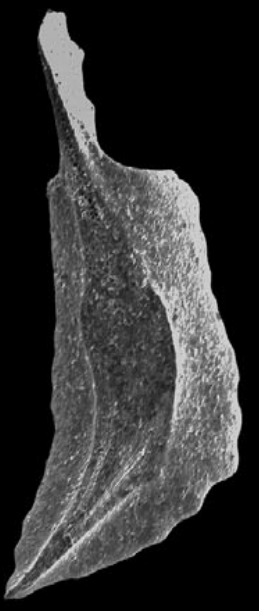

H

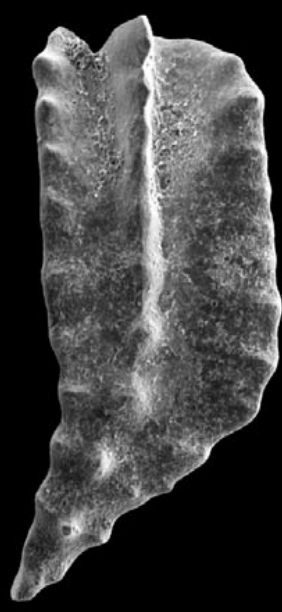

I

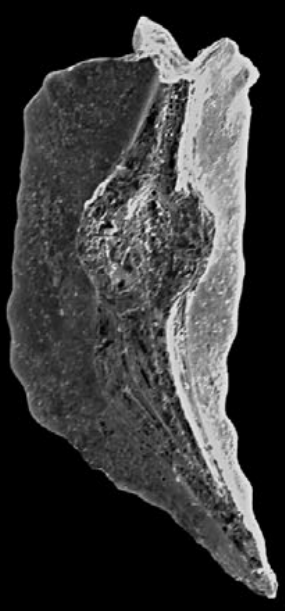

J
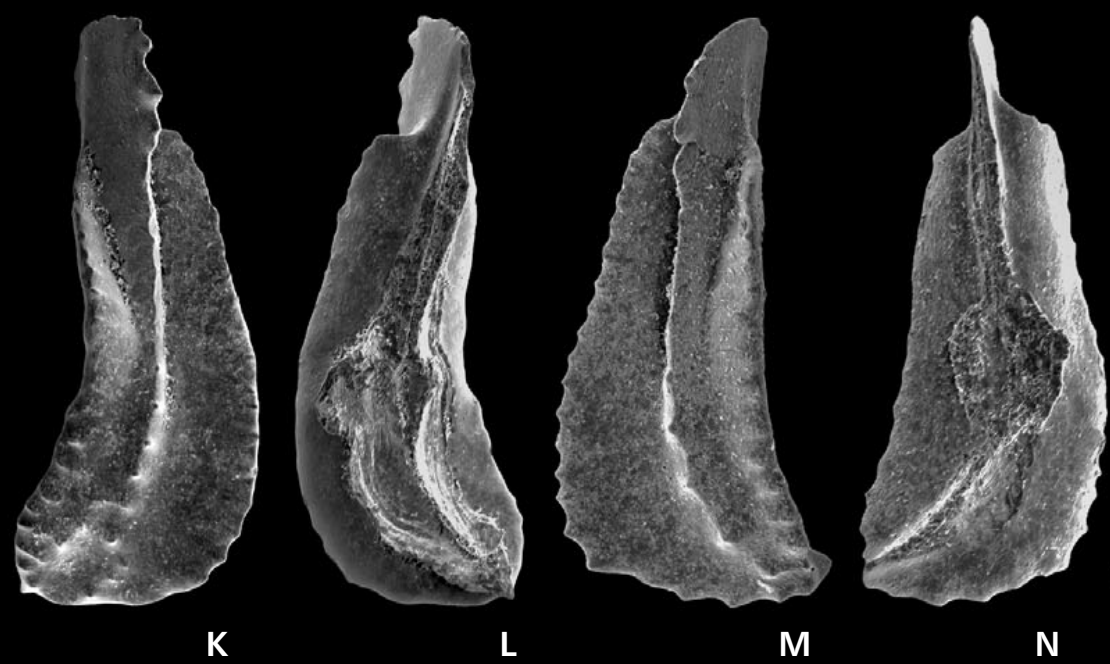

N
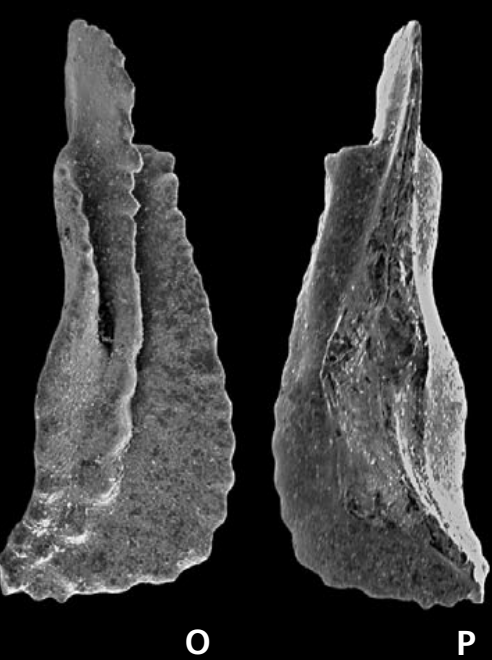
somewhat similar but there is no clear evidence for a posterior cavity inversion in its type material. The new specimens show trends towards Eol. jacksoni, especially some specimens with relatively small basal cavity. They may represent a new species between Eol. rarus and Eol. jacksoni, which we leave currently in open nomenclature. In the related "Polygnathus sp. 1" of Luppold (1987), the platform is smoother, narrower, and less curved in the posterior part.

Stratigraphic range. - Anetoceras Limestone, catharinae Subzone.

\section{Eolinguipolygnathus jacksoni (Bardashev, Weddige \& Ziegler, 2002) \\ Figure 9K-P}

$$
\begin{array}{ll}
\text { e.p. } 1989 \begin{array}{l}
\text { Polygnathus laticostatus Klapper \& Johnson. - Bul- } \\
\text { tynck, p. 185, pl. 3, figs 9-11 (only). }
\end{array} \\
\text { e.p. } 1989 \begin{array}{l}
\text { Polygnathus gronbergi-laticostatus. - Bultynck, } \\
\text { pl. 3, figs 5, 8 (only). }
\end{array} \\
\text { *2002 } \begin{array}{l}
\text { Costapolygnathus jacksoni sp. nov.; Bardashev, } \\
\text { Weddige \& Ziegler, pp. 415-416. }
\end{array}
\end{array}
$$

Description. - A population from Bed $31 \mathrm{a}_{1}$ at Jebel Ihrs gives insights into the ontogeny and variability of the species. Most characteristic is the asymmetric drop-shape. The largest representative (Fig. 9K) is more elongate than the smaller specimens, which display somewhat narrower and deeper anterior adcarinal troughs. The inner platform margin is slightly convex to straight at small to median size (Fig. 9M) but strongly concave in the largest specimen or undulose in a third specimen (Fig. 90). Since all specimens come from one population it is clear that there is considerable variability in the shape and size of the basal cavity. The central basal pit is moderately large and flat (Fig. 9N, P) but does not become relatively smaller with growth. Curved, shelf-like extensions characterize especially the posterior outer part and can be pronounced at large size (Fig. 9L). The posterior cavity inversion is always pronounced. The proportions of the free blade decreases from $>1 / 3$ of total length in small specimens to less than $1 / 5$ in the adult. It is moderately prominent, with three larger denticles. The carina is lower than the free blade, with fused denticles in the anterior part and small, low, isolated denticles (Fig. 90) or wide and unclearly defined denticles
(Fig. 9K) near the end. It does not reach the posterior tip. In the posterior half there are adjacent, smooth, wide adcarinal depressions. There are either transverse costae or the posterior margin, especially its widened outer part, is markedly serrate. There is no clear lingua.

Discussion. - The new Tafilalt population lacks any characteristics of Eol. laticostatus and provides support that Eol. jacksoni is a valid species, which can be well defined despite some intraspecific variability. It was originally based on specimens from the La Grange Limestone assigned by Bultynck (1989) to Eol. laticostatus but should also include some of Bultynck's transitional specimens from gronbergi. Eol. jacksoni obviously belongs to a so far neglected lineage with characteristic suboval platform shape and feeble ornament that probably evolved in parallel to the other lower Emsian polygnathids. Most ancestral, with a still non-inverted basal cavity, are a specimen from the German Harz Mountains assigned to Po. gronbergi in Luppold (1987, fig. 8.1a, b) and the Russian Eol. rarus. Eolinguipolygnathus arthuri provides a morphological transition from the excavatus Group, which is supported by its stratigraphic position. In the narrow Polygnathus sp. 1 sensu Luppold (1987) and in our Eol. aff. gronbergi, the posterior cavity has started to invert. Progressing inversion led to Eol. jacksoni. Its shelf-like extensions under the outer platform resemble those in Eol. catharinae and Eol. vigierei and served the attachment of the basal body. Eolinguipolygnathus cf. laticostatus (see below) with a basal pit represents the end member of the morphological and assumed phylogenetic series.

Geographic distribution. - Armorican Massif, Anti-Atlas (new record).

Stratigraphic range. - Upper part of inversus Zone.

Eolinguipolygnathus laticostatus

(Klapper \& Johnson, 1975)

Figures 10C, D, G-L, 15K, $c f .15 \mathrm{~L}, \mathrm{M}, \mathrm{T}-\mathrm{U}, 21 \mathrm{~K}$

*e.p. 1975 Polygnathus laticostatus sp. nov.; Klapper \& Johnson, p. 74, pl. 2, figs 20, 21, 28, 29 (only).

1980 Polygnathus laticostatus Klapper \& Johnson. - Bultynck \& Hollard, p. 43, pl. 2, figs 9-11.

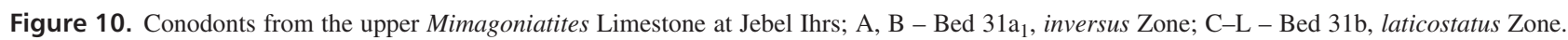
- A, B - Linguipolygnathus sp. nov., B9.A-5.144, ×60. • C, D - Eol. laticostatus (Klapper \& Johnson, 1975) Morphotype beta. With strongly concave outer anterior platform margin, B9.A-5.18, × 60. • E, F - Eol. vigierei (Bultynck, 1989). B9.A-5.19, × 50. • G-K - Eol. laticostatus (Klapper \& Johnson, 1975) Morphotype beta. Three specimens showing the variation of the anterior platform margin; $\mathrm{G}, \mathrm{H}$ - with only weakly concave outer anterior platform margin and relatively large basal pit, B9.A-5.21, × 60; I, J - smaller specimen with large and shallow basal pit, B9.A-5.41, $\times 75 ; \mathrm{K}-\mathrm{B} 9 . \mathrm{A}-5.20, \times 65$. - L - Eol. laticostatus (Klapper \& Johnson, 1975) Morphotype alpha. With convex outer anterior platform margin, B9.A-5.22, × 65. 


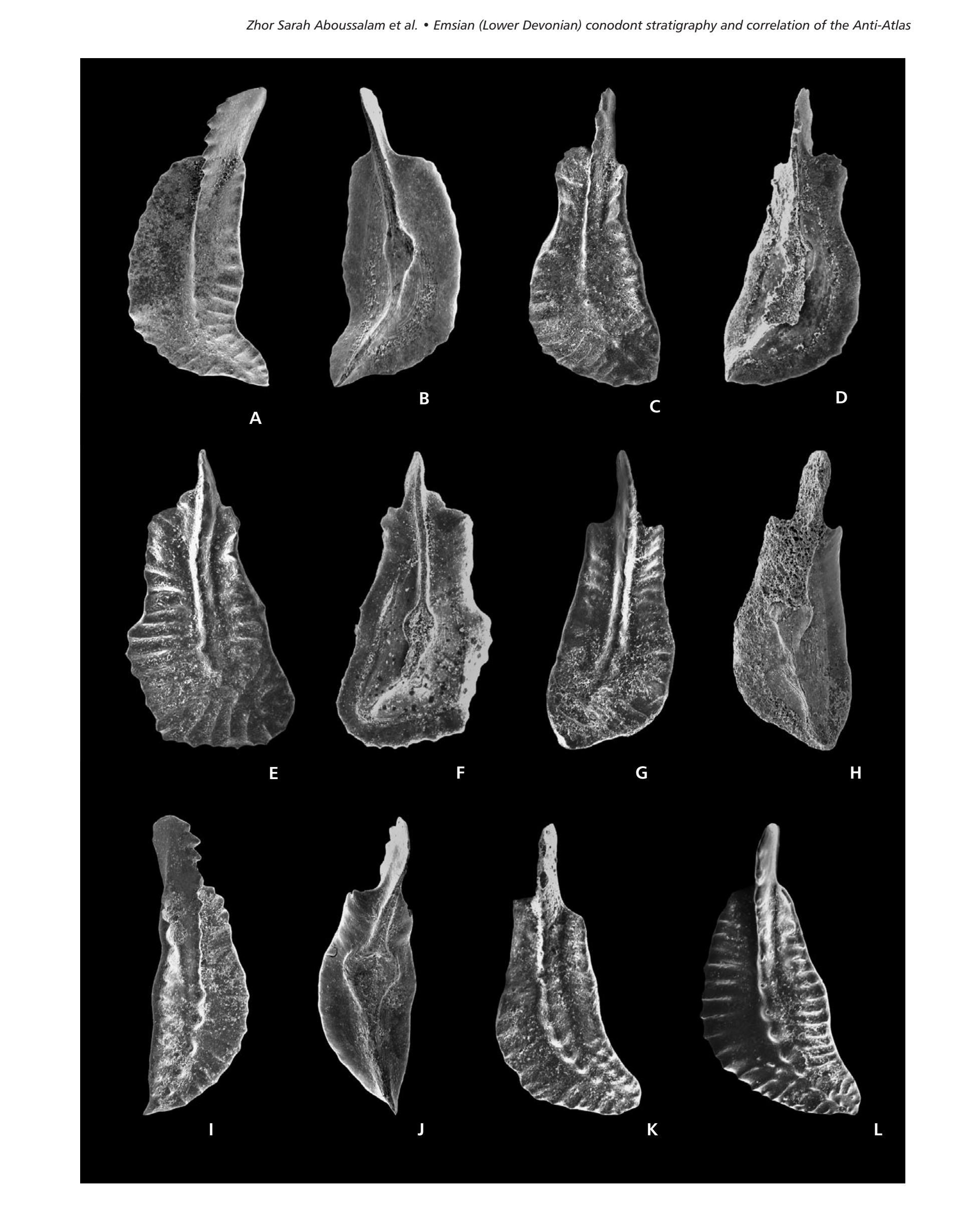


1985 Polygnathus laticostatus Klapper \& Johnson. - Bultynck, pl. 5, figs 19, ?20.

e.p. 1987 Polygnathus laticostatus Klapper \& Johnson. - Luppold, p. 311, fig. 8.2a, b [figs 7.2a, b and 8.2a, b = sp. nov.].

e.p. 1989 Polygnathus laticostatus Klapper \& Johnson. - Bultynck, p. 185, pl. 3, fig. 12a, b (only) [figs 9-11= Eol.jacksoni].

non 1990 Polygnathus cf. laticostatus Klapper \& Johnson. García-López et al., pl. II, figs 26, 27 [= gilberti].

non 2013 Polygnathus laticostatus Klapper \& Johnson. - Lu, p. 316, pl. 2, fig. 1.

non 2013 Polygnathus cf. laticostatus Klapper \& Johnson. Lu, p. 316, pl. 1, fig. 10.

Desription. - Four of the representatives from the top of the Mimagoniatites Limestone of Jebel Ihrs differ from typical laticostatus in a gentle (Fig. 10G-K) to marked (Fig. 10C, D) concave anterior, outer platform margin and angular to pointed anterior platform shoulders. The outer posterior margin is always markedly convex, without any angularity. The inner platform margin is straight (Fig. 10G) or slightly undulose. The basal pit is very shallow but relatively wide in small specimens (Fig. 10J) and relatively smaller in larger ones (Fig. 10D, H).

Several specimens from equivalent strata of Section BTW (Fig. 15L, M, T, U) differ by an extended posterior outer platform with reduced ornament, which is much wider than the inner platform. The platform shape is asymmetrically drop-shaped, with an almost straight, blunt, posterior platform front.

Discussion. - Bardashev (1986), Bultynck (1989), Bardashev \& Ziegler (1992), and Bardashev et al. (2002) removed forms with a large, well-developed, broadly rounded or triangular lingua from the Nevada type series of Po. laticostatus as Po. gilberti and added similar forms from France and Tadzhikistan. The absence of specimens with "gilberti morphology" from the laticostatus faunas of Jebel Ihrs and Bou Tchrafine supports the distinction. The remaining laticostatus types (s. str.) from Nevada and many other representatives show a convex outer platform and small platform angles at the anterior end. This typical form is here defined as Morphotype alpha, whilst our form from Jebel Ihrs with outer platform concavity and marked anterior shoulders is placed in a new Morphotype beta. It has previously been illustrated from the Tafilalt (Bultynck \& Hollard 1980, pl. II, fig. 10a, b) and Maider (Bultynck
1985, pl. 5, fig. 19). Bardashev et al. (2002) placed the latter specimen in their Costapolygnathus telfordi, the holotype of which, however, has a very different platform shape and basal cavity. The restriction of Morphotype beta to the eastern Anti-Atlas may justify the introduction of a new taxon (e.g., a new subspecies). However, there are intermediates within one bed that connect Morphotype alpha (Fig. 10L, close to the holotype) and beta (Fig. 10C, D) end members. A better documentation of the intraspecific variability in successive beds of other regions would be helpful to clarify the taxonomy of the species.

Apart from the two morphotypes of the typical laticostatus there are specimens from the Harz Mountains (Luppold 1987; see above) and BTW with extended outer posterior platform, which are here called cf. laticostatus. They possess platforms similar as in Eol. jacksoni and may represent a distinctive (sub)species or a third morphotype. Bardashev et al. (2002) suggested that typical Eol. laticostatus evolved from Eol. gronbergi, via forms assigned to Eoc. philipi (a species based on Rzhonsnitskaya et al. 1990, pl. 9, figs 9, 10). The transitional specimen figured by Klapper \& Johnson (1975, pl. 1, figs 25, 26) fits a direct gronbergi-laticostatus transition. It combines a strong basal cavity inversion with the anterior platform shoulders of our Morphotype beta and an incipient outer platform concavity. The gronbergi-laticostatus intermediate of García-López et al. (1990) is poorly preserved but similar. It is well possible that our Eol. cf. laticostatus derived independently from Eol. jacksoni.

The moderate size of the basal pit, the short semicrossed lingua, and the supposed independent origin (e.g., Klapper \& Johnson 1975, Bultynck, 1989) justifies our placing of laticostatus in Eolinguipolygnathus rather than in Polygnathus (= Eucostapolygnathus) or Linguipolygnathus.

Geographic distribution. - Pan(sub)tropical, from Alaska and northern Gondwana to South China and the Russian Far East.

Stratigraphic range. - Both morphotypes and Eol. cf. laticostatus are restricted to the laticostatus Zone.

\section{Eolinguipolygnathus annamariae (Bultynck, 1989)} Figure 9G, H

* 1989 Polygnathus annamariae sp. nov.; Bultynck, p. 184, pl. 6 , figs 4,5 .

Figure 11. Emsian to Eifelian outcrops at Bou Tchrafine West, Bou Tchrafine North, and Hamar Laghdad South. • A - position of section Bou Tchrafine West (arrow) in the plain to the west of the main (Eifelian-Givetian) cliff. $\bullet$ B - position of section Bou Tchrafine North in the plain below the western extension of the Hamar Laghdad ridge, with section HLS II at the foot of the low northern cliff. The western margin of the Pragian Hamar Laghdad Mudmounds forms the foreground in the lower right corner. 

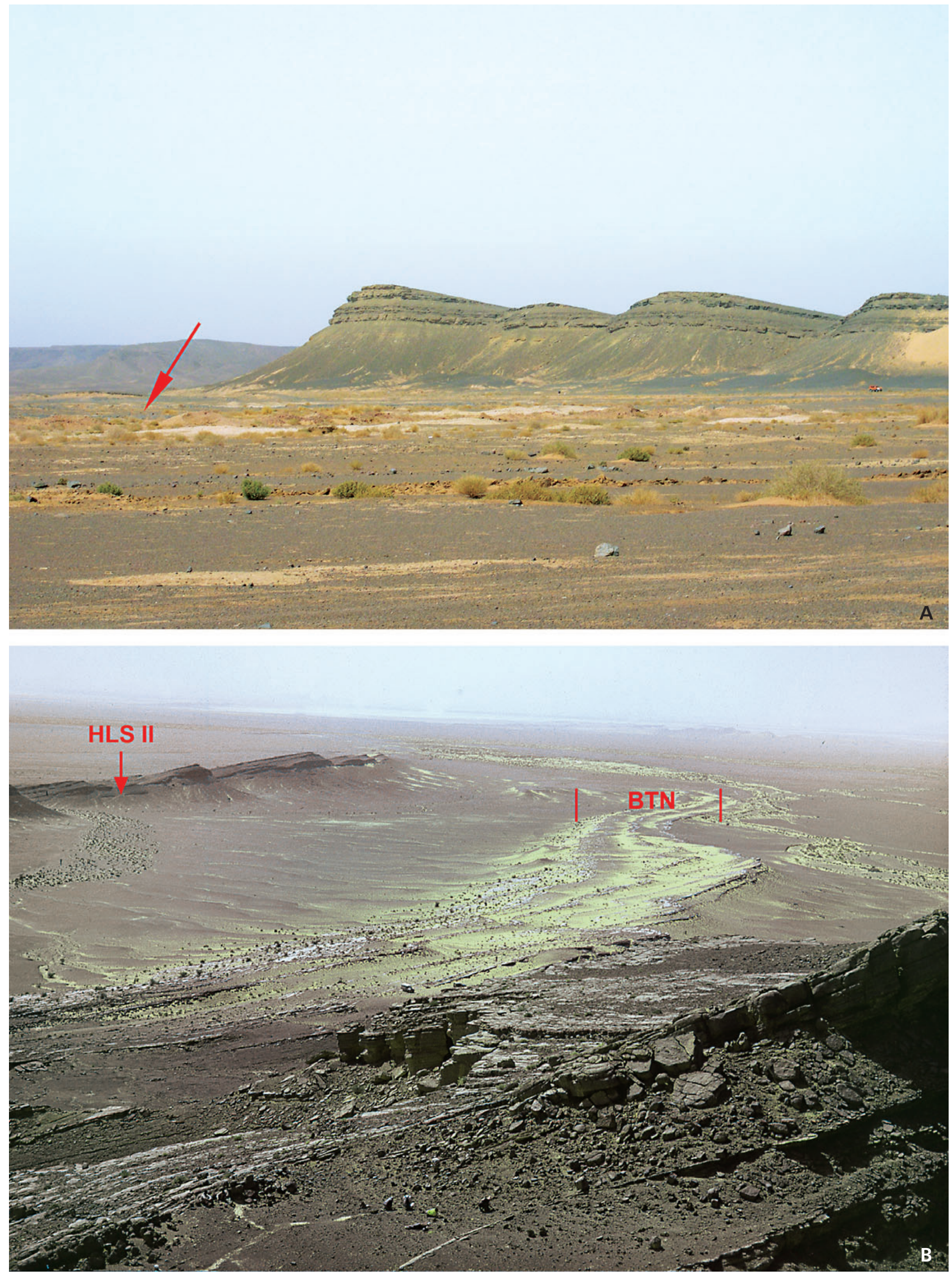


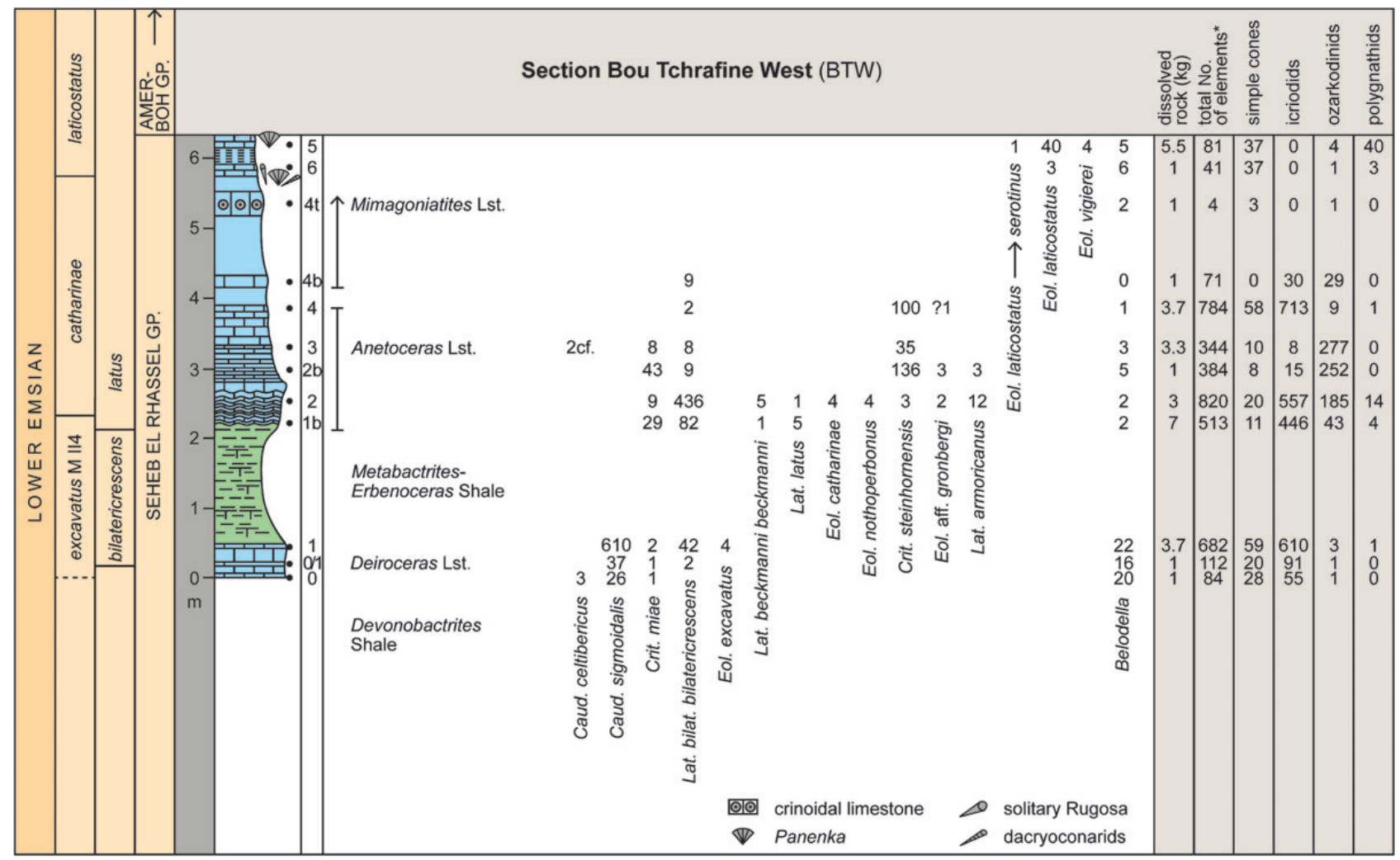

Figure 12. Lower Emsian lithological succession, sample positions, conodont ranges and abundances at Bou Tchrafine West (central Tafilalt). For additional symbols see Fig. 4. *The total number of elements partly includes ramiforms, which are not assigned to any of the four listed groups.

2002 Eolinguipolygnathus annamariae (Bultynck). Bardashev, Weddige \& Ziegler, pp. 407-408.

Discussion. - A single specimen from Jebel Ihrs (Bed 31a $\mathrm{a}_{1}$ ) resembles the paratype of Eol. annamariae figured by Bultynck (1989, pl. 6, fig. 5a, b), which Bardashev et al. (2002) placed in their Morphotype beta. It is also very close to the holotype of Po. mashkovae latus Aksenova, 1987, which, however, is an invalid junior homonym of Po. latus Wittekindt, 1966. Eol. mashkovae Bardashev, 1986 differs mostly in the narrower anterior platform with deep adcarinal furrows and in a much more inverted basal cavity. Eol. perbonus and Eol. labiosus are more slender, with deeper anterior adcarinal troughs.

Geographic distribution. - ?Tadzhikistan, Armorican Massif, Anti-Atlas (new record).

Stratigraphic range. - Restricted to the inversus Zone.

\section{Eolinguipolygnathus gilberti (Bardashev, 1986)} Figure 21J

*e.p. 1975 Polygnathus laticostatus sp. nov.; Klapper \& John- son, p. 74, pl. 1, figs 29-32, pl. 2, figs 22-26, 30, 32, 33 (only).

* 1986 Polygnathus gilberti sp. nov.; Bardashev, pp. 63-64, pl. V, figs 17, 18.

1990 Polygnathus cf. laticostatus Klapper \& Johnson. García-López et al., pl. II, figs 26, 27.

1992 Polygnathus laticostatus Klapper \& Johnson. - Bardashev \& Ziegler, pl. 5, figs 1-6.

1992 Polygnathus gilberti Klapper \& Johnson. - Bardashev \& Ziegler, pl. 6, figs 1-4, 6-11, 22.

2002 Polygnathus gilberti Bardashev. - Bardashev, Weddige \& Ziegler, p. 422.

* 2002 Linguipolygnathus talenti Bardashev, Weddige \& Ziegler, pp. 422-423.

non 2013 Polygnathus gilberti Bardashev. - Lu, p. 315, pl. 1, figs 6, 7 [a new species].

non 2013 Polygnathus cf. gilberti Bardashev. - Lu, p. 316, pl. 1, figs 8,9 [variants of the new species].

Discussion. - Bardashev (1986) first separated only two originals of Po. laticostatus Klapper \& Johnson, 1975 with broadly rounded long lingua as Po. gilberti. But his types from Tadzhikistan possess a large, triangular lingua. Therefore, it is consequent that Bardashev et al. (2002) added similar Nevada types to their gilberti syno- 


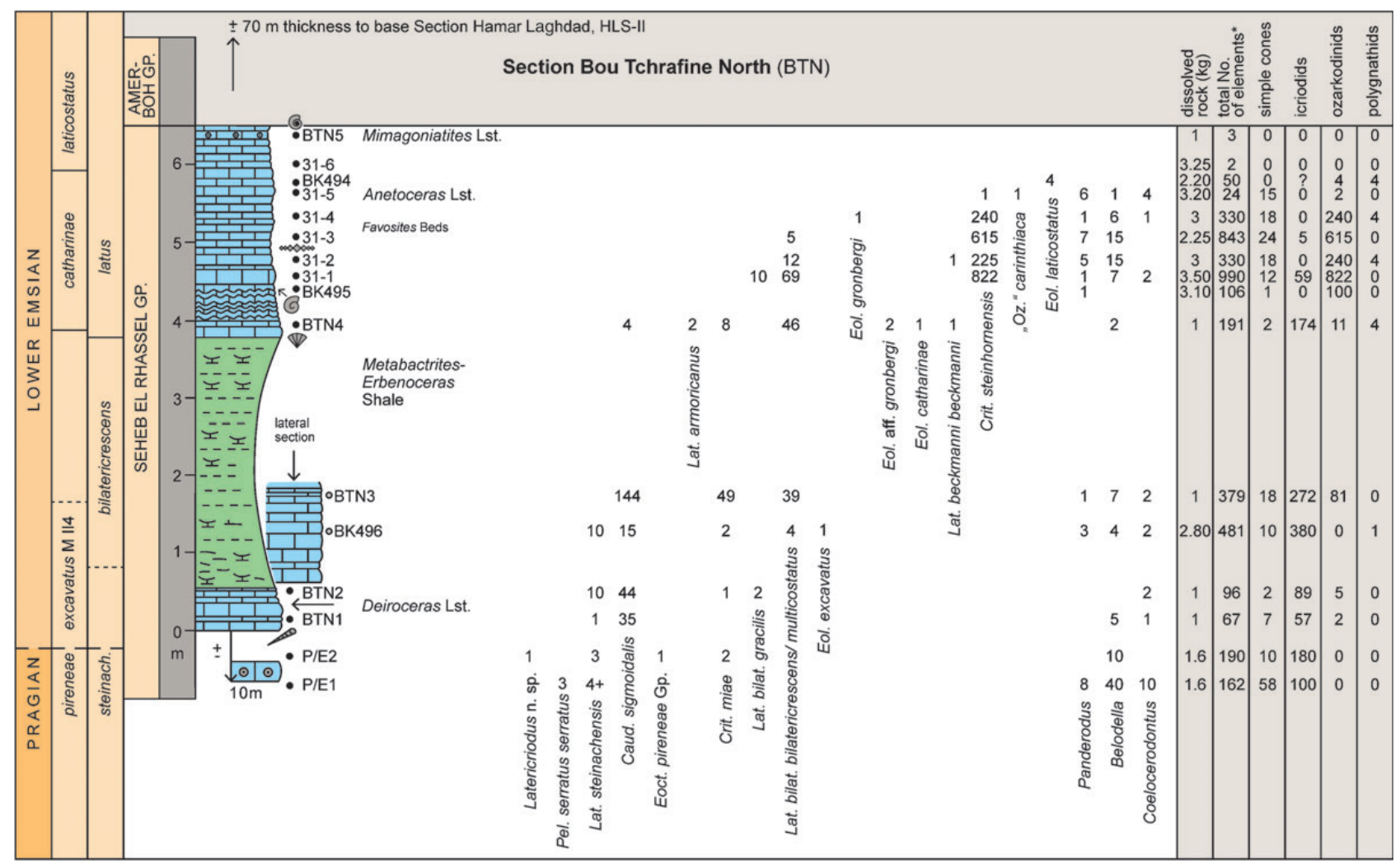

Figure 13. Upper Pragian to lower Emsian lithological succession, sample positions, conodont ranges and abundances at Bou Tchrafine North (east-central Tafilalt). For symbols see Figs 4 and 12. *The total number of elements includes variable amounts ramiforms, which are not assigned to any of the four listed groups.

nymy. Both morphotypes were illustrated by Bultynck (1989) from La Grange but his Pa elements are very wide, with semicircular outer platform margin. Two additional French specimens, identified by Bultynck (1989) as Po. ?gilberti, have somewhat narrower platforms. They resemble some of the Nevada paratypes. We do not support the separation of such variants (morphotypes) as a different species ( $L$. talenti Bardashev, Weddige \& Ziegler, 2002).

Our specimen from the top of Bed 22 at El Khraouia is a relatively narrow morphotype with triangular lingua. It closely resembles specimens from the type region figured by Bardashev \& Ziegler (1992, especially pl. 6, fig. 10). Specimens illustrated from South China by Lu (2013), including cf. forms, posses a very different platform ornament, with diverging anterior ridges and adcarinal furrows; they do not resemble any named Emsian taxon.

Geographic distribution. - Alaska, Nevada, Armorican Massif, Pyrenees, Catalonia (NE Spain), Anti-Atlas (new record), Uzbekistan, Tadzhikistan, South China.

Stratigraphic range. - Restricted to the laticostatus Zone.

\section{Eocostapolygnathus juferevi (Aksenova, 1987)}

Figures 8L, M, $c f .21 \mathrm{~N}, \mathrm{O}$

cf. 1985 Polygnathus gronbergi Klapper \& Johnson. - Bultynck, fig. 4, pl. 5, fig. 16.

cf. 1986 Polygnathus dehiscens Philip \& Jackson. - Barca et al., pl. 29, figs 3-5.

* 1987 Polygnathus juferevi sp. nov.; Aksenova, pp. 91-92, pl. 26, figs 8, 10, pl. 27, figs 4-6.

cf. 1989 Polygnathus dehiscens dehiscens Philip \& Jackson. - Bultynck, pl. 3, fig. 1a-c [= pierrei holotype].

*cf. 2002 Eocostapolygnathus pierrei sp. nov.; Bardashev, Weddige \& Ziegler, p. 405 (holotype only).

e.p. 2002 Eocostapolygnathus juferevi (Aksenova) alpha morphotype. - Bardashev, Weddige \& Ziegler, pp. 403-404 [Aksenova types only].

Description. - A single specimen (B9.A-5.13, Fig. 8L, M) from the lower part of Bed 21a at Jebel Ihrs differs from all other lower Emsian polygnathids of the region. It displays a well-rounded, curved and ribbed outer posterior platform, which is shorter than the strong, moderately curved carina that reaches the posterior end. The inner platform is reduced and mostly has a row of nodes that 


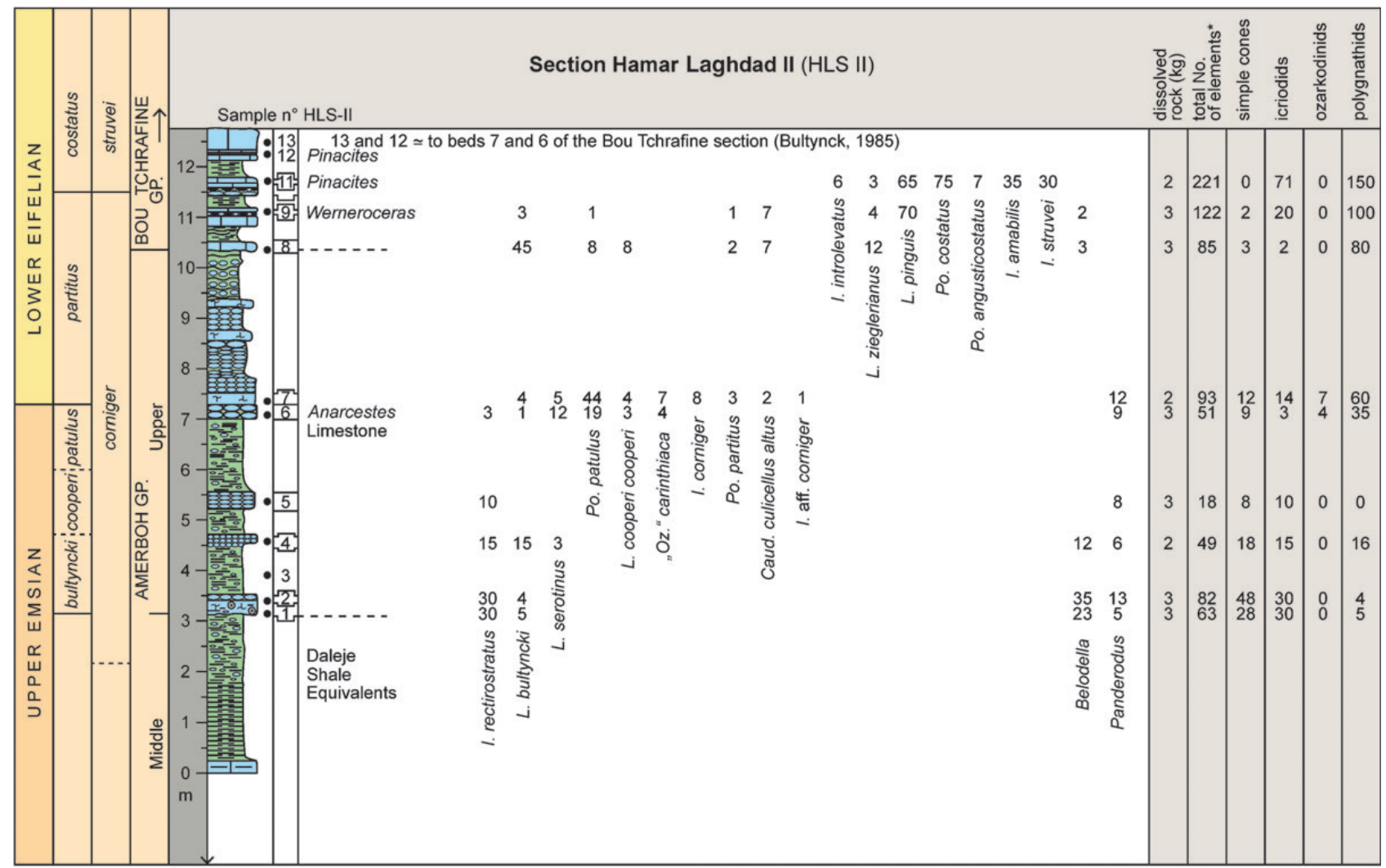

Figure 14. Lithological succession, sample positions, and conodont record at Hamar Laghdad SW (HLS II, east-central Tafilalt).

joines smoothly the gently curved anterior platform end and the carina at the posterior platform tip. The basal cavity is wide and shallow, without posterior inversion. Adcarinal troughs are well developed, especially on the outer side, and smooth.

In two specimens from the top of Bed 22 at El Khraouia (Fig. 21N, O) a wide, flat and rather poorly demarcated basal cavity flexes upwards at the posterior tip but it is not really inverted. The somewhat subrectangular platform has high, upturned margins with only weak transverse costae and wide and smooth adcarinal troughs along a low, ridge-like carina that dissolves into small denticles towards the posterior end. The outer platform margin forms a distinctive, slightly costate corner. The inner platform has been reduced to a narrow ridge, which becomes lower near the posterior end.

Figure 15. Polygnathid conodonts from the Emsian of Bou Tchrafine and Hamar Laghdad SW (HLS II, east-central Tafilalt), all $\times 47$. $\bullet$ A-D, G - Eol. excavatus (Carls \& Gandl, 1969) typical morphotype. Sample BTW1, upper Deiroceras Limestone, upper excavatus M114 Zone; A - lower view with basal cavity, b6591; B - lower view, b6592; C, D - upper and lower views, b6593; G - lower view of small specimen, b6594. • E, F - Eol. nothoperbonus (Mawson, 1987). Upper and lower views of incomplete specimen b6595, Sample BTW2, lower part of Anetoceras Limestone, catharinae Subzone. - H-J - Eol. aff. gronbergi (Klapper \& Johnson, 1975). Specimens with marked transverse costae and extended outer posterior platform, lower Anetoceras Limestone, catharinae Subzone, probably ancestral to Eol. jacksoni; H - Sample BTW2, b6596; I, J - Sample BTN4, b6597. • K - Eol. laticostatus (Klapper \& Johnson, 1975). Upper view of typical specimen, b6598, Sample BTW6, middle Mimagoniatites Limestone, laticostatus Zone. - L, M - Eol. cf. laticostatus (Klapper \& Johnson, 1975). Specimens with outer posterior platform extension and reduced ornament as in Eol. jacksoni but with more strongly inverted basal cavity, Sample BTW5, top of Mimagoniatites Limestone, laticostatus Zone; L - upper view of b6599; M - lower view of b6600. • N, O, S - Eol. catharinae (Bultynck, 1989). Sample BTW2, lower Anetoceras Limestone, catharinae Subzone; N, O - upper and lower views of b6605; S - upper view of b6606. P , Q - Eol. vigierei (Bultynck, 1989). Sample BTW5, top Mimagoniatites Limestone, laticostatus Zone; P - upper view of b6607; Q - lower view of b6608. • R - Eol. laticostatus (Klapper \& Johnson, 1975) towards L. serotinus (Telford, 1975). Small specimen with bilobate posterior platform as in the serotinus juvenile of Telford (1975, pl. 7, fig. 9) and as in some serotinus Morphotype 3 sensu Klapper \& Vodrážková (2013), b6604, top Mimagoniatites Limestone, laticostatus Zone. • T, U - Eol. cf. laticostatus (Klapper \& Johnson, 1975). Specimens resembling Eol. jacksoni but without shelf extensions of basal cavity; T - lower view of b6601; U - upper view of b6602. • V - L. bultyncki (Weddige, 1977). Upper view of b6609, Sample HLS II-2, lower Anarcestes Limestone, bultyncki Zone. • W - L. serotinus (Telford, 1975) Morphotype 2 sensu Klapper \& Vodrážková (2013). Lower view of b6610, Sample HLS II-4, middle Anarcestes Limestone, cooperi Subzone. • X - L. serotinus (Telford, 1975). Upper view of b6611, Sample HLS II-6, top Anarcestes Limestone, patulus Zone. 

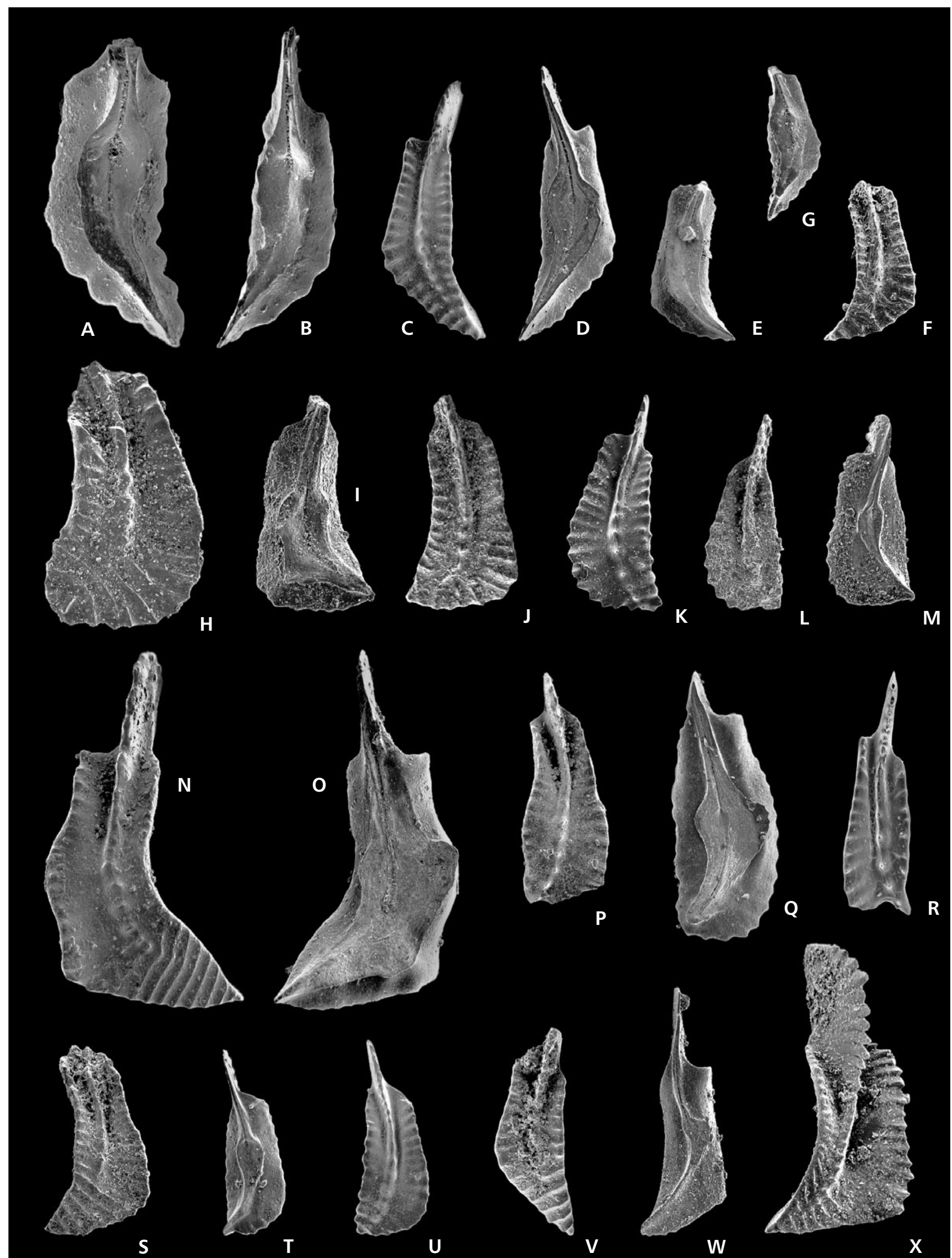
Discussion. - The Jebel Ihrs specimen strongly resembles paratype 1652/26 of Eoc. juferevi, illustrated by Aksenova (1987, pl. 27, fig. 6). Specimen B9.A-5.64 from El Khraouia closely resembles the holotype of Eoc. pierrei Bardashev, Weddige \& Ziegler, 2002, which was based on a supposed dehiscens specimen from the gronbergi Zone of the La Grange Limestone (Bultynck 1989, pl. 3, fig. 1a-c). But there are also similarities with the holotype of Eoc. juferevi, in which the outer platform is less convex and less costate than in the paratypes. Since the holotypes and para- types of Eoc. juferevi indicate some intraspecific variability in the species, the holotype of Eoc. pierrei and our El Khraouia specimens may only represent end members of the spectrum. Until more details become known, we assign pierrei-like forms with a cf. to juferevi.

We do not apply the intraspecific morphotype separation of Bardashev et al. (2002). The juferevi type material has a bowed, upward flexed posterior lower platform without a clear cavity inversion at the pointed tip. Most of the other polygnathids quoted under juferevi in Bardashev et

Figure 16. Conodonts from the Pragian to Eifelian of the Tafilalt; A-S - upper Emsian to lower Eifelian of Hamar Laghdad SW (HLS II); T, U - Pragian of Bou Tchrafine North; V-X - basal Emsian of BTW, all $\times 47$. $\bullet$ A - L. bultyncki (Weddige, 1977). Upper view of specimen that is transitional towards L. zieglerianus (Weddige, 1977), b6612, Sample HLS II-1, lower Anarcestes Limestone, bultyncki Zone. • B - L. bultyncki (Weddige, 1977), Morphotype beta sensu Wang \& Ziegler (1983). With concave outer posterior platform margin, b6613, Sample HLS II-8, basal Eifelian Limestone, higher partitus Zone. • C-E - Po. patulus Klapper, 1971. Upper views of three specimens; C - b6614, Sample HLS II-6, top Anarcestes Limestone, patulus Zone; D - b6615, Sample HLS II-7, basal partitus Zone; E - b6616, Sample HLS II-8 (age as 2). • F, G - Po. partitus Klapper, Ziegler \& Mashkova, 1978. Upper and lower views, b6617, Sample HLS II-8 (age as B). • H-J - L. bultyncki (Weddige, 1977), Morphotype beta sensu Ziegler \& Wang (1983). Upper views of three specimens; H - b6618, Sample HLS II-11, lower Eifelian Limestone, basal costatus Zone; I - b6619, Sample HLS II-8 (age as B); J - b6620, lower Eifelian Limestone, top partitus Zone. $\bullet$ K, L - L. pinguis (Weddige, 1977). Upper views of two specimens, Sample HLS II-11, basal costatus Zone; K - b6621; L - b6622. • M - L. pinguis? (Weddige, 1977). Aberrant form (or new taxon) with unusual, nodose platform, b6623, Sample HLS II-9, higher partitus Zone. • N - Po. costatus Klapper, 1971. B6624, Sample HLS II-11, basal costatus Zone. • O, P - Po. angusticostatus Wittekindt, 1966. Upper and outer lateral views of two specimens, Sample HLS II-11, basal costatus Zone; O - b6625; P - 6626. -Q-S - “Oz.” carinthiaca Schulze, 1968. Upper and outer lateral views of three specimens, Sample HLS II-7, basal partitus Zone; Q - b6627; R - b6628; $\mathrm{S}$ - b6629. • T, U - Pel. serratus serratus Jentzsch, 1962. Inner lateral and upper views, b6603, Sample BTN P/E1, Pragian, steinachensis Zone. V-X - Caud. celtibericus (Carls \& Gandl, 1969). Upper views of three specimens, Sample BTW0, basal Deiroceras Limestone, lower Emsian (by correlation bilatericrescens gracilis Zone); V - b6630; W - b6631, transitional from Caud. curvicauda (Carls \& Gandl, 1969$)$; X - b6632.

Figure 17 (page 950). Conodonts from the Pragian to upper Emsian of Bou Tchrafine and Hamar Laghdad SW (HLS II), all $\times 47$ unless stated otherwise. • A, B, E - Lat. steinachensis (Al-Rawi, 1977). Late morphotype with straight spindle; A, B - lower and upper views of b6633, Sample BTN Bk496, middle Deiroceras Limestone, lower Emsian, bilatericrescens bilatericrescens Zone; E - upper view of b6635, Sample BTN2, upper Deiroceras Limestone, lower Emsian, bilatericrescens bilatericrescens Zone. $\bullet$ C - Lat. steinachensis (Al-Rawi, 1977) Morphotype eta. Typical form, upper view, Sample BTN P/E2, steinachensis Zone, Pragian. • D - Caud. sigmoidalis (Carls \& Gandl, 1969). Upper view, b6636, Sample BTW1, upper Deiroceras Limestone, bilatericrescens bilatericrescens Zone. • F - Lat. bilatericrescens bilatericrescens (Ziegler, 1956). Upper view, b6637, Sample BTN4, basal Anetoceras Limestone, latus Zone (locally with Lat. armoricanus). $・ \mathrm{G}-$ Lat. bilatericrescens bilatericrescens (Ziegler, 1956). Transitional from bilatericrescens gracilis Bultynck, 1985, upper view, b6638, Sample BTN4 (age as F). $\bullet$ H-J - Lat. bilatericrescens gracilis Bultynck, 1985. Upper views of three specimens; H - b6639, Sample BTN4 (age as F, G); I - b6639, Sample BTN4 (age as F, G); J - b6640, 6641, Sample BTN2 (age as E). - K-M - Lat. latus (Al-Rawi, 1977). Upper views of three specimens, Sample BTW1b, basal Anetoceras Limestone, basal latus Zone; K - b6643; L - b6644; M - b6645, × 80. - N, O - Lat. armoricanus Bultynck, 1989. Upper and lower views, b6642, Sample BTW2, lower Anetoceras Limestone, latus Zone. $\bullet$ P-U - I. rectirostratus Bultynck, 1970. Upper and lower views of three specimens, Sample HLS II-1, lower Anarcestes Limestone, bultyncki Zone; P, Q - b6646; R, S - b6647; T, U - b6648.

Figure 18 (page 951). Conodonts from the Pragian to lower Eifelian of Bou Tchrafine, Hamar Laghdad SW (HLS II), and Rich el M'Bidia, an auxiliary locality of the eastern Dra Valley, all $\times 47$, unless stated otherwise. $\bullet$ A, B - Caudicriodus culicellus altus (Weddige in Weddige \& Requadt, 1985). Upper and outer lateral views of two specimens, Sample HLS II-7, basal Eifelian Limestone, basal partitus Zone; A - b6649; B - 6650. • C - I. aff. corniger Wittekindt, 1966. Upper view of specimen with symmetric posterior end of cavity, b6651, Sample HLS II-7 (age as A, B). • D-F - I. corniger corniger Wittekindt, 1966. Sample HLS II-9, lower Eifelian Limestone, higher partitus Zone; D - lower view of b6652; E - upper view of b6653; F - upper view of juvenile b6654. • G-I - I. introlevatus Bultynck, 1970. Upper and lower views of three specimens, Sample HLS II-11, basal costatus Zone; G-b6655; H-b6656; I- 6657. • J-L - I. amabilis Bultynck \& Hollard, 1980. Lower and upper views of three specimens, Sample HLS II-11 (age as G-I); J - b6658; K - b6659; L - b6660. • M-P - Crit. miae (Bultynck, 1971); M, N - upper and inner lateral views of b6661, Sample BTW1, upper Deiroceras Limestone, upper excavatus M114 or miae Zone; O, P - upper and outer lateral views of b6662, Sample BTW2, lower Anetoceras Limestone, basal steinhornensis Zone. • Q, R - Crit. steinhornensis (Ziegler, 1956); Q - upper view of b6663, Sample BTW2, basal steinhornensis Zone; R - upper view of b6664, Rich el M'Bidia, Sample 7, lower Mdâouer-el-Kbîr Formation, steinhornensis Zone. • S-U - Latericriodus sp. nov. Upper, lower and side views, b6665, Sample BTN P/E2, Pragian, steinachensis Zone. $・ V-X-E o c t$. pireneae (Boersma, 1974) Group. Incomplete specimen, upper, lower and oblique lateral views, b6666, Sample BTN P/E2 (age as S-U), $\times 80$. 


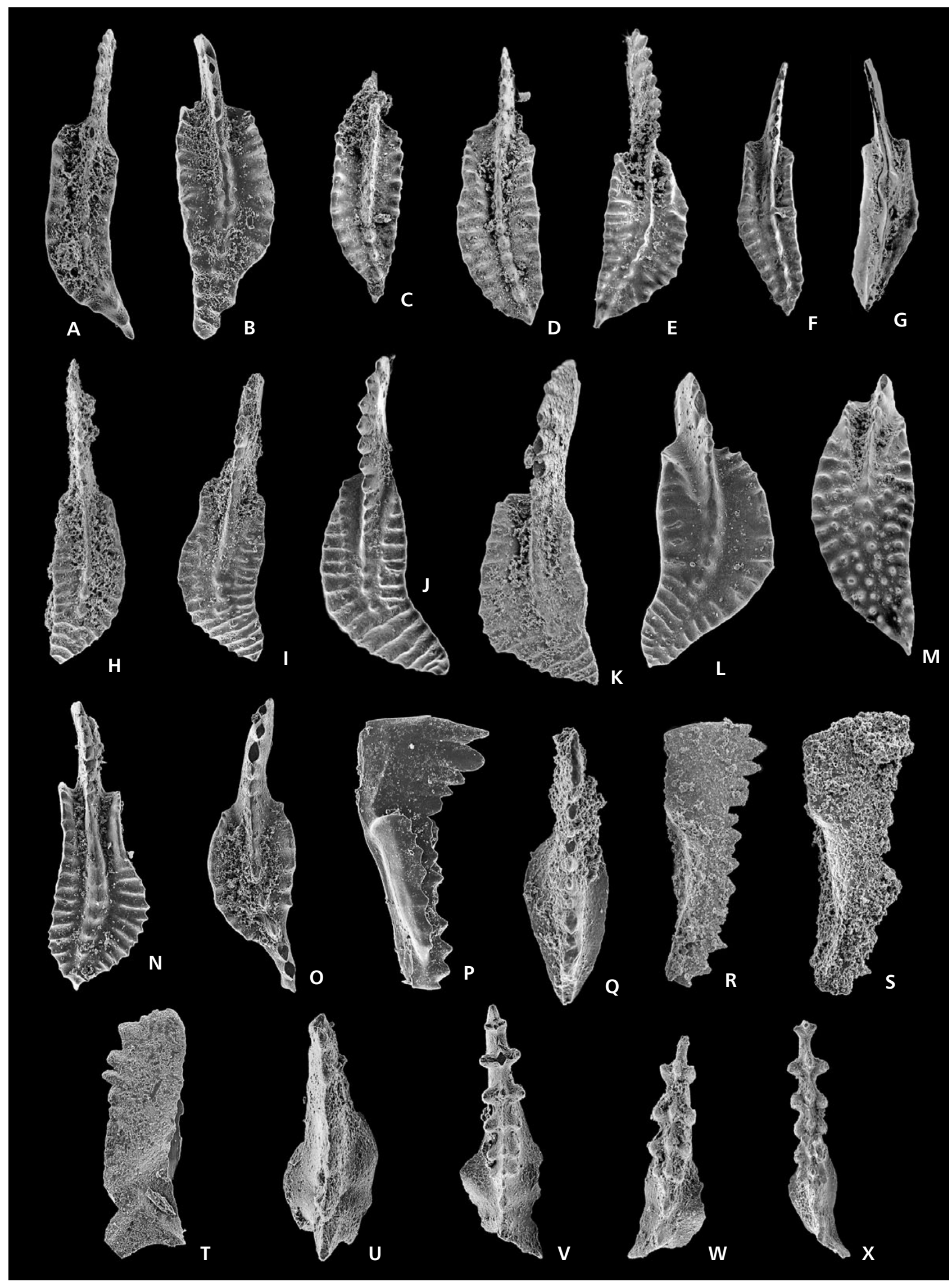



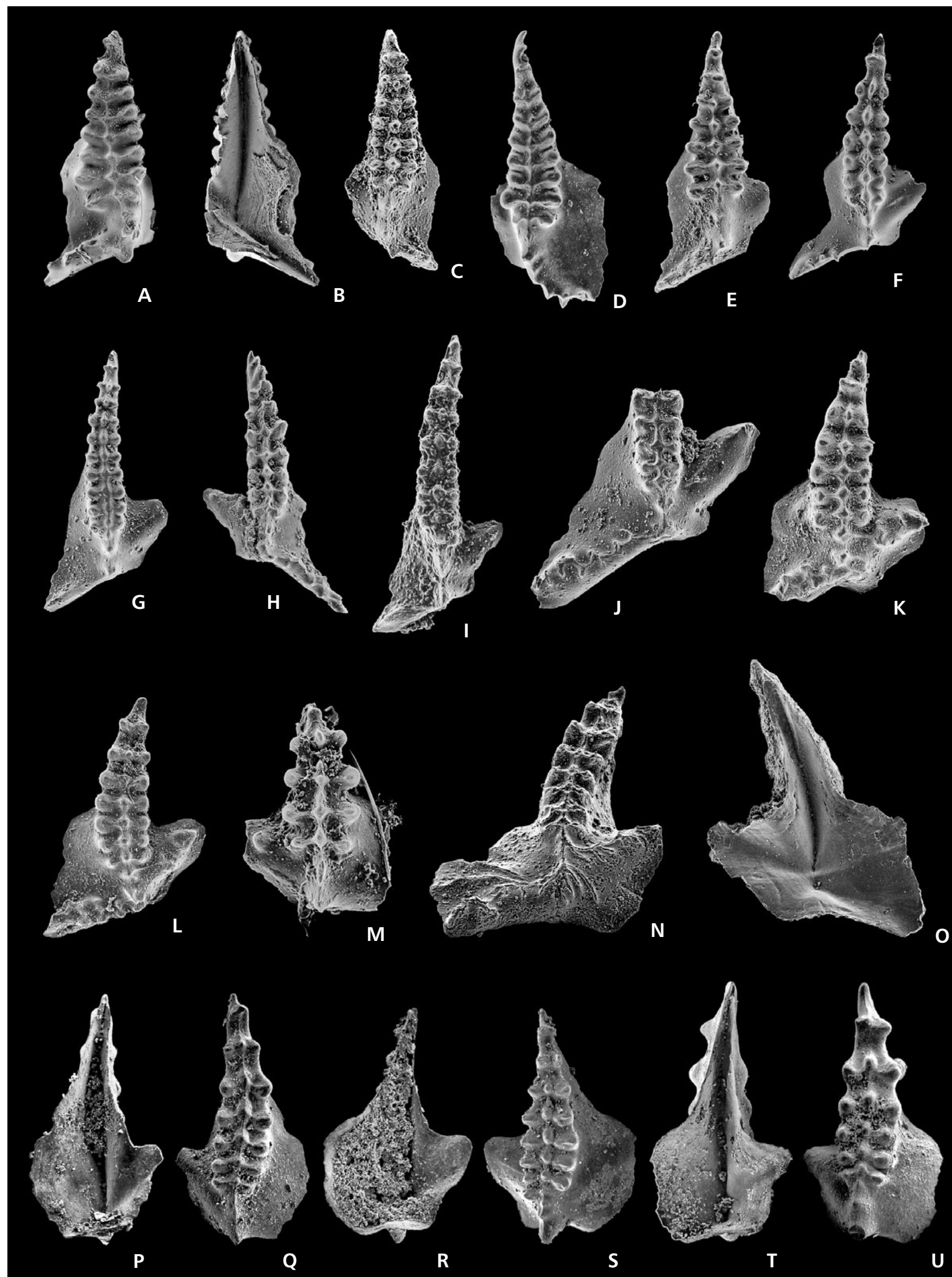


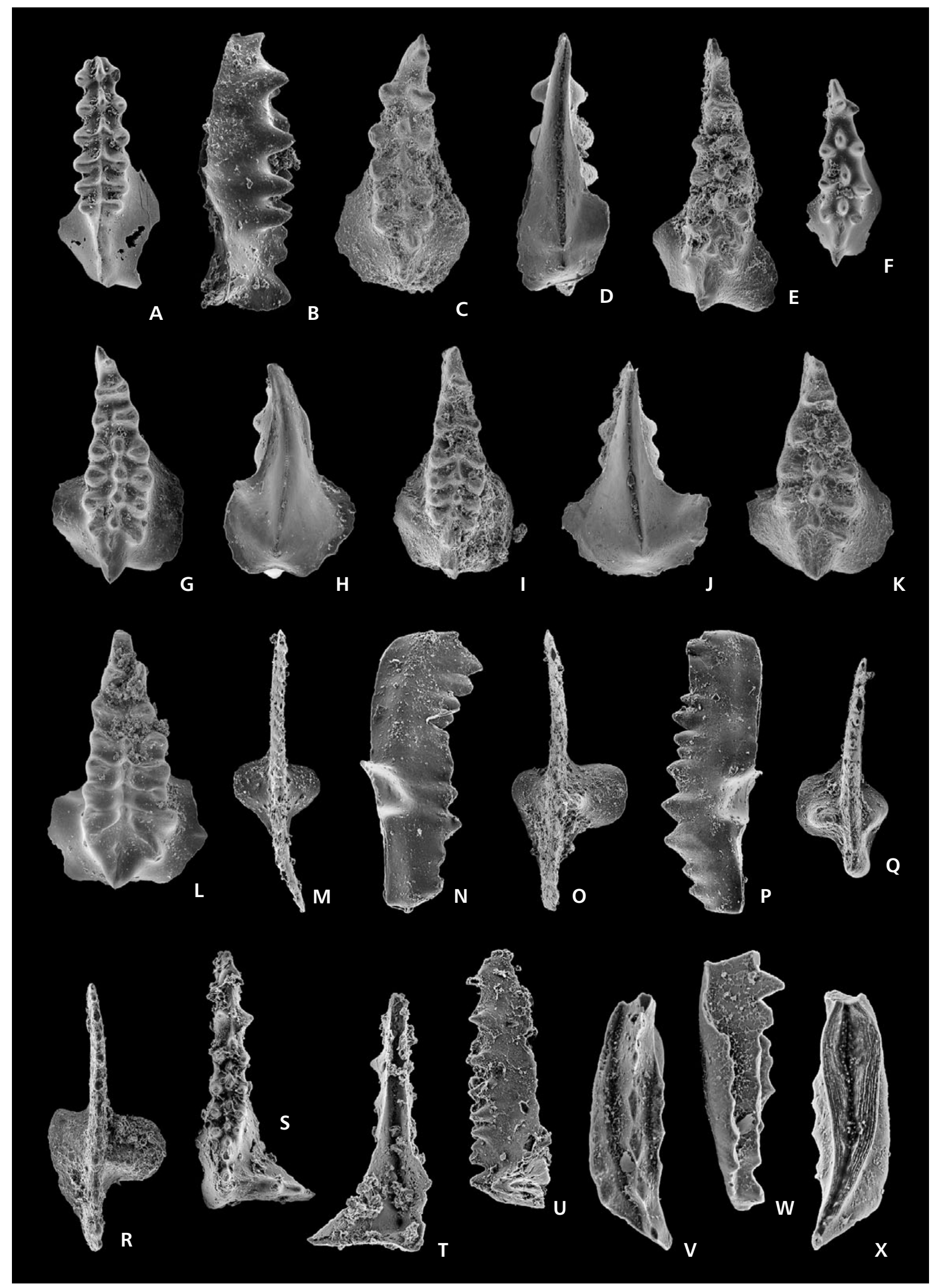


al. (2002) do not conform to the types. They lack the posterior carina, which leaves no lingua. But we agree with Bardashev et al. (2002) that the extended outer posterior platform of a gronbergi specimen from Ou Driss, figured in Bultynck (1985), resembles Eol. juferevi. A rather smooth specimen with fine posterior carina, figured in Bultynck (1989, pl. 3, fig. 7a, b) as transitional form between Eol. gronbergi and Eol. laticostatus, is also similar but the inner platform is wider. Polygnathus sp. 3 of Luppold (1987) is possibly an extreme variant of this group with especially wide platform; its basal cavity is not known. This form was questionably assigned to Eoc. juferevi in Bardashev et al. (2002).

Eoc. lenzi (sensu its holotype) lacks the widening of the outer posterior platform and shows a different transverse platform ornament. In the holotype of the related Eoc. richi, originally figured by Lane \& Ormiston (1979, pl. 6, figs 21,22 ) as Po. cf. gronbergi, there are two to three rows of nodes on the central platform.

Geographic distribution. - Central Asia (Gorny Altai), Armorican Massif, $c f$. Sardinia, and Anti-Atlas.

Stratigraphic range. - Gronbergi and (cf. specimens) laticostatus zones.

\section{Linguipolygnathus sp. nov.}

\section{Figure 10A, B}

Description. - A single specimen from Bed $31 \mathrm{a}_{1}$ at Jebel Ihrs does not resemble any named lower Emsian polygnathid. It has a very short free blade with four denticles plus an incipient denticle at the front. The subrectangular platform has upturned margins, the outer of which is higher than the inner. The margins bear regular transverse costae but there are wide, smooth adcarinal troughs. The outer margin curves sharply inwards near the posterior end, followed by a small, asymmetric lingua that is demarcated by constrictions. The inner platform margin is slightly convex. The tranverse ridges of the lingua weaken in the middle. The central basal pit is small, as in a typical Linguipolygnathus, with a very incipient outer protuberance.

Discussion. - There is a slight resemblance to Eol. tomi Bardashev, Weddige \& Ziegler, 2002 and Eol. senckenbergi Bardashev, Weedige \& Ziegler, 2002, which both have a narrower platform and a less inverted basal cavity.

The constricted lingua distinguishes the Jebel Ihrs specimen from L. khalymbadzhai Bardashev, Weddige \& Ziegler, 2002 (perhaps better a subspecies of L. johnsoni Bardashev, Weddige \& Ziegler, 2002), and the younger L. bultyncki [which includes L. mawsonae (Long \& Burret,
1989), see Klapper \& Vodrážková 2013]. Since only one specimen is currently available, open nomenclature is preferred for this possibly new species, which lies close to the rootstock of upper Emsian linguipolygnathids.

Geographic distribution. - Only known from the Anti-Atlas.

Stratigraphic range. - Upper part of inversus Zone.

\section{Linguipolygnathus aff. inversus \\ Klapper \& Johnson, 1975 \\ Figure 25Z, AA}

Description. - Specimens from the Mdâouer-el-Kbîr and lower Timrhanrhart formations of the eastern Dra Valley are characterized by a basal, subsymmetric pit without outer lip, which is situated under the anterior third of the platform. The straight anterior part of the platform and the incurved, well-developed tongue are about of the same length. The carina fades as a series of minor, superimposed nodes on the anterior half of the tongue, just behind the platform inflexion.

Discussion. - Typical L. inversus, in the sense of the holotype and of a specimen illustrated in Fig. 25AB, AC, lack a well-developed tongue. Forms assigned to L. khalymbadzhai in Bardashev et al. (2002) differ in deeper adcarinal furrows of the anterior platform and in an elevated, angular outer platform corner. There are similarities with L. johnsoni, which, however, is characterized by an outer lip of the basal pit, as in L. serotinus, and the inner platform is markedly narrower than the outer.

Stratigraphic range. - In the Anti-Atlas, this form is so far known from the lower Emsian inversus Zone to the upper Emsian Sellanarcestes Limestone of the eastern Dra Valley (level of I. aff. corniger, ca basal corniger Zone).

\section{Caudicriodus celtibericus (Carls \& Gandl, 1969)}

Figures 5C, D, 16V-X, ?20A, H, M, 22N, 28A, aff. 29M

* 1969 Icriodus huddlei celtibericus n. ssp.; Carls \& Gandl, pp. 182-183, pl. 16, figs 18-20.

1976 Caudicriodus celtibericus (Carls \& Gandl). - Bultynck, pp. 29-31, pl. 6, figs 7-19, pl. 7, figs 27-29.

1979 Caudicriodus celtibericus (Carls \& Gandl). - Bultynck, pl. 2, fig. 18.

1990 Icriodus celtibericus Carls \& Gandl. - Olivieri \& Serpagli, p. 62, pl. 1, figs 1-5, 19.

1995 Caudicriodus celtibericus (Carls \& Gandl). - Kalvoda, pp. 35-36, pl. 1, figs 5-9, 11, pl. 2, figs 1, 4. 
Figure 19. Lower Emsian lithological successions and position of conodont samples at Hassi Nebech (TA) and El Khraouia (MA; both Taouz region, SE Tafilalt).

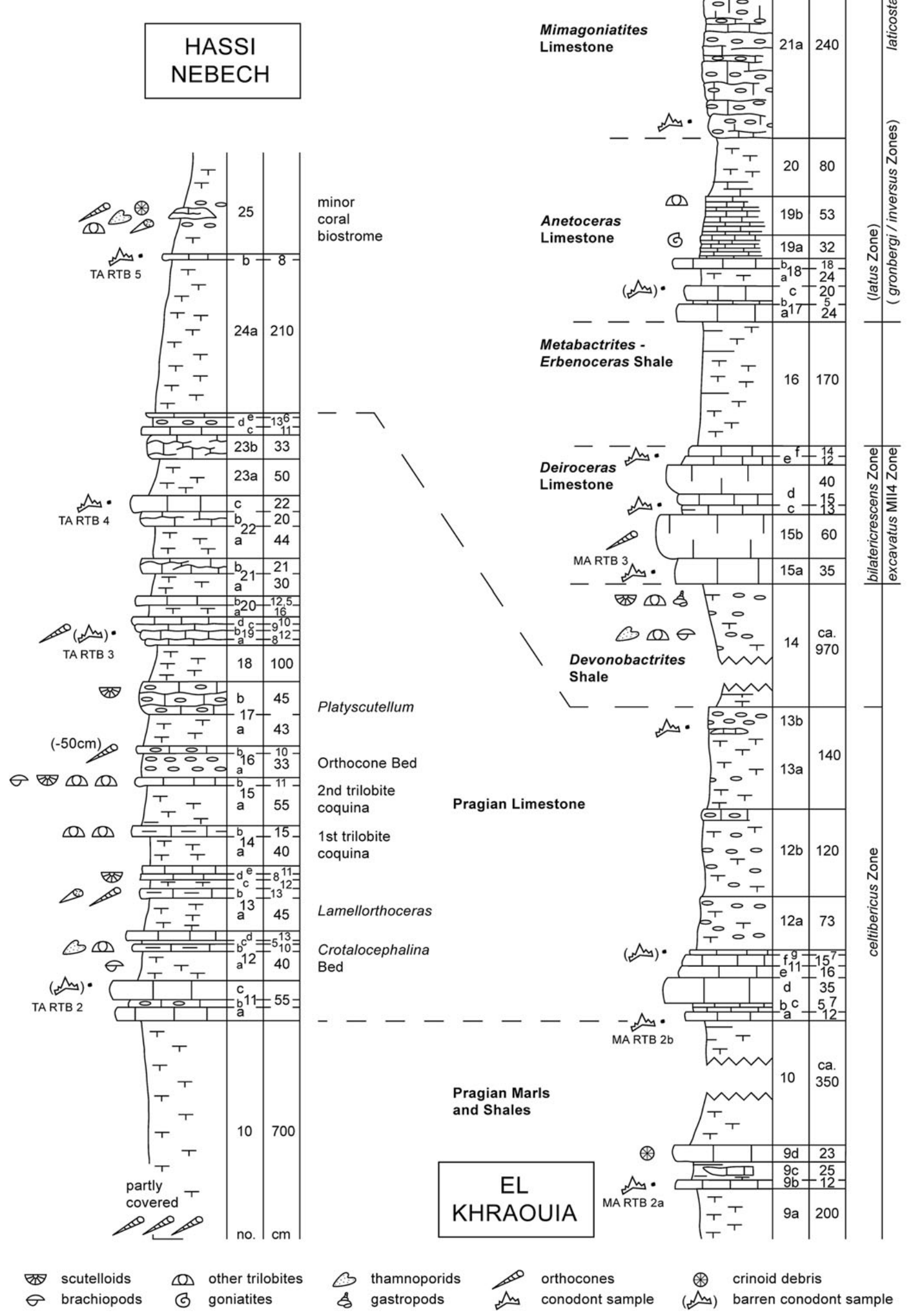


2001 Caudicriodus celtibericus (Carls \& Gandl). - Slavík, p. 261, pl. 2, fig. 7 .

2003 Caudicriodus celtibericus (Carls \& Gandl). - Bultynck, fig. 1, line 4, pl. 1, fig. 27.

2004a Caudicriodus celtibericus (Carls \& Gandl). - Slavík, pl. 1, figs 7, 8 .

2004b Caudicriodus celtibericus (Carls \& Gandl). - Slavík, fig. 11.1-3.

Description. - The spindle of Caud. celtibericus is narrow and slightly concavo-convex. The tip of the denticles on the spindle are rounded; the two to three middle row denticles behind the spindle are higher than those on the spindle. The middle-and lateral row denticles are not connected. The length of the outer posterior lateral process is about $1 / 3$ of the length of the spindle and is not denticulated. The angle between the axis of the spindle and posterior lateral process is between $130^{\circ}$ and $110^{\circ}$. There is no development of a spur on the inner posterior side of the element.
In the posteriormost part of the spindle the distance between the transversal denticle rows is smaller than on the main part of the spindle.

Discussion. - Specimens from the "Pragian Limestone" are variably very narrow (Fig. 5D) or wider (Fig. 5C). Juveniles have in general only few transverse rows of nodes (five in Fig. 20H, six in Fig. 20M, only three in Fig. 22N, four in Fig. 28A). Questionable specimens from the oldest sample (steinachensis Zone) at El Khraouia (top Bed 8, Fig. 20A) are incomplete. In these, the presence of a second main denticle behind the platform and of a lateral process cannot be verified. But the posterior extension of the basal cavity speaks against Caud. curvicauda and there is no narrowing of the posterior row interspaces as in the associated Lat. steinachensis or Lat. cf. claudiae. Small-sized specimens from the basal "Pragian Limestone" of Hassi Nebech (Sample TA4, e.g., Fig. 22N) are somewhat intermediate from Caud. curvicauda.

Figure 20. Conodonts from El Khraouia; A-D - top Bed 8, top "Pragian Marls and Shales", steinachensis Zone; E-G - Bed 9b, top "Pragian Marls and Shales", steinachensis Zone; H - "Pragian Limestone", Bed 11a, celtibericus Zone; I-M - Deiroceras Limestone, Bed 15a, bilatericrescens gracilis and excavatus Morphotype 114 zones; N-Q - Deiroceras Limestone, Bed 15f, bilatericrescens bilatericrescens Zone. • A - Caud. ?celtibericus (Carls \& Gandl, 1969). B9.A-5.144, juvenile specimen, $\times 150$ • B, C - Lat. cf. claudiae (Klapper, 1980 in Johnson et al. 1980). Two specimens, posterior end incomplete, $\times$ 85; B - B9.A-5.145; C - B9.A-5.146. D - Lat. steinachensis (Al-Rawi, 1977) Morphotype beta. With straight median axis, B9.A-5.147, $\times 60 . \bullet-$ Bel. triangularis (Stauffer, 1940). B9.A-5.43, $\times 50 . \bullet F-$ Caud. cf. curvicauda sensu Carls \& Gandl (1969, pl. 16, fig. 17), B9.A-5.44, juvenile, $\times$ 120. $\bullet \mathrm{G}-$ Bel. resima (Philip, 1965). B9.A-5.42, $\times 65 . \bullet \mathrm{H}-$ Caud. celtibericus (Carls \& Gandl, 1969). Small specimen, transitional from Caud. curvicauda (Carls \& Gandl, 1969), B9.A-5.45, $\times 115 . \bullet$ I, J - Eol. excavatus (Carls \& Gandl, 1969) Morphotype 114. B9.A-5.53, juvenile, $\times 120$. - K - "Acodina sp." (coniform icriodid). B9.A-5.52, × 120. • L - Caud. sigmoidalis (Carls \& Gandl, 1969). B9.A-5.46, × 55. • M - Caud. celtibericus (Carls \& Gandl, 1969). Median-sized specimen, B9.A-5.48, $\times 75 . \bullet \mathrm{N}-\mathrm{Q}-$ Lat. bilatericrescens multicostatus (Carls \& Gandl, 1969). Four specimens illustrating the variability; N - B9.A-5.50, × 50; O - B9.A-5.51, ×50; P-B9.A-5.148, × 40; Q - B9.A-5.149, ×65.

Figure 21 (page 956). Conodonts from the Deiroceras and upper Mimagoniatites Limestone of El Khraouia; A, B - Bed 15a; C-H - Bed 15f; both excavatus Morphotype 114 Zone; I-Q - top Bed 22, laticostatus Zone. • A - Neop. perlineatus Ziegler \& Lindström, 1971. B9.A-5.47, × 120. • B - Crit. miae (Bultynck, 1971). B9.A-5.49, $\times 75$. $・$ C - Eol. radula sp. nov. Strongly curved paratype with constricted tongue, B9.A-5.56, $\times 60$. $・$ D-F - Eol. excavatus (Carls \& Gandl, 1969) Morphotype 114. Typical specimens with narrow platform and upturned anterior platform margins; D - B9.A-5.57, $\times 100$; E - B9.A-5.58, × 75; F - B9.A-5.59, × 60. $\bullet \mathrm{G}, \mathrm{H}-$ Lat. bilatericrescens gracilis Bultynck, 1985. G- B9.A-5.54, × 75; H - B9.A-5.55, × 60 . - I - Eol. cf. vigierei (Bultynck, 1989). Incomplete specimen with serrate, strongly extended outer platform corner, B9.A-5.60, × 70. • J - L. gilberti (Bardashev, 1986). Morphotype with triangular lingua, B9.A-5.62, × 75. $-\mathrm{K}-$ Eol. laticostatus (Klapper \& Johnson, 1975). B9.A-5.63, × 100. - L, M - Caud. ultimus Weddige in Weddige \& Requadt, 1985. Upper and oblique view, B9.A-5.61, × 100. • N, O - Eoc. cf. juferevi (Aksenova, 1987). Specimen resembling the French holotype of Eoc. pierrei Bardashev, Weddige \& Ziegler, 2002, B9.A-5.64, × 55. • P, Q - Eol. vigierei (Bultynck, 1989). Slightly transitional to Eol. gilberti, B9.A-5.150, $\times 60$.

Figure 22 (page 957). Lower Emsian conodonts from the southern Tafilalt; A-K - Jebel el-Mrier; L-N - Hassi Nebech. • A - Caud. sigmoidalis (Carls \& Gandl, 1969). B9.A-5.65, Sample AL RTB 6, Deiroceras Limestone, bilatericrescens Zone, $\times 60 . \bullet$ B - Lat. bilatericrescens bilatericrescens (Ziegler, 1956). B9.A-5.66, Sample AL RTB 6 (level as 1) $\times 65$. $・$ C - Lat. bilatericrescens multicostatus (Carls \& Gandl, 1969). Morphotype with double-rowed processes, B9.A-5.67, Sample AL RTB 7a, Anetoceras Limestone, steinhornensis Zone, $\times$ 50. • D - Crit. steinhornensis (Ziegler, 1956). B9.A-5.68, Sample AL RTB 7a (level as 3), ×60. • E, H - Neop. perlineatus Ziegler \& Lindström, 1971; E - specimen from Sample AL RTB 8, B9.A-5.69, × 65; H - specimen from Sample AL RTB 9a, B9.A-5.70, × 60; both Mimagoniatites Limestone, steinhornensis Zone. •F, G - Eol. cf. gronbergi (Klapper \& Johnson, 1975). Abraded specimen, B9.A-5.71, Sample AL RTB 8 (level as E) $\times$ 75. $・$ I, K - Bel. triangularis (Stauffer, 1940). Both upper Mimagoniatites Limestone, upper steinhornensis Zone/Upper Belodella Ecozone; I - specimen from Sample AL RTB 9a, B9.A-5.72, × 80; K - specimen from Sample AL RTB 9b (11, B9.A-5.73, × 75. • J - Crit. steinhornensis (Ziegler, 1956), B9.A-5.74, × 85, AL RTB 9b (level as I). $\bullet$ L, M - Bel. resima (Philip, 1965). Two specimens from the higher part of the "Pragian Limestone", celtibericus Zone, Sample TA RTB 4; L - B9.A-5.75, juvenile, $\times 150 ;$ M - B9.A-5.76, $\times 45$. $・ N-$ Caud. celtibericus (Carls \& Gandl, 1969). Small specimen, somewhat similar to Caud. curvicauda, B9.A-5.77, Sample TA RTB 4 (level as 11), × 120. 


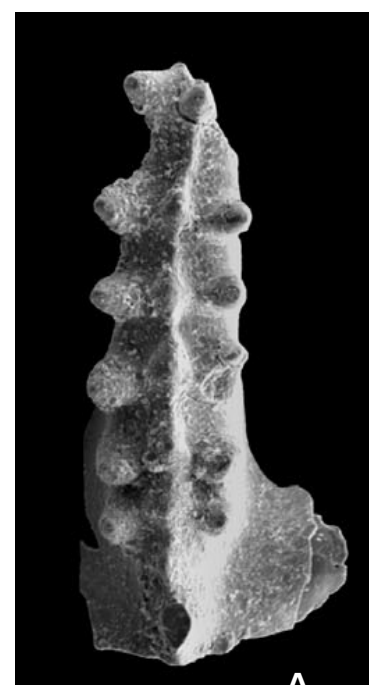

A
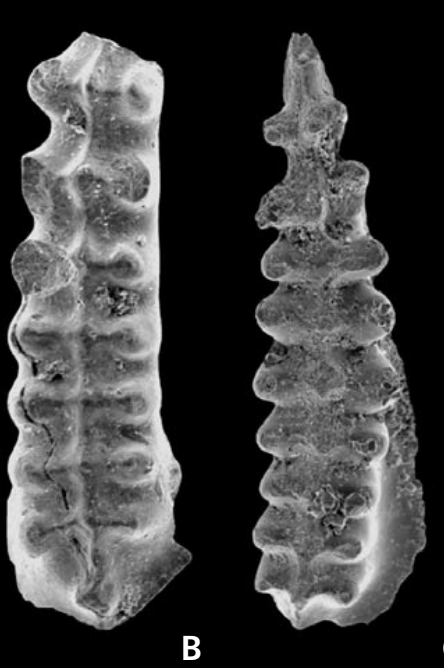

C
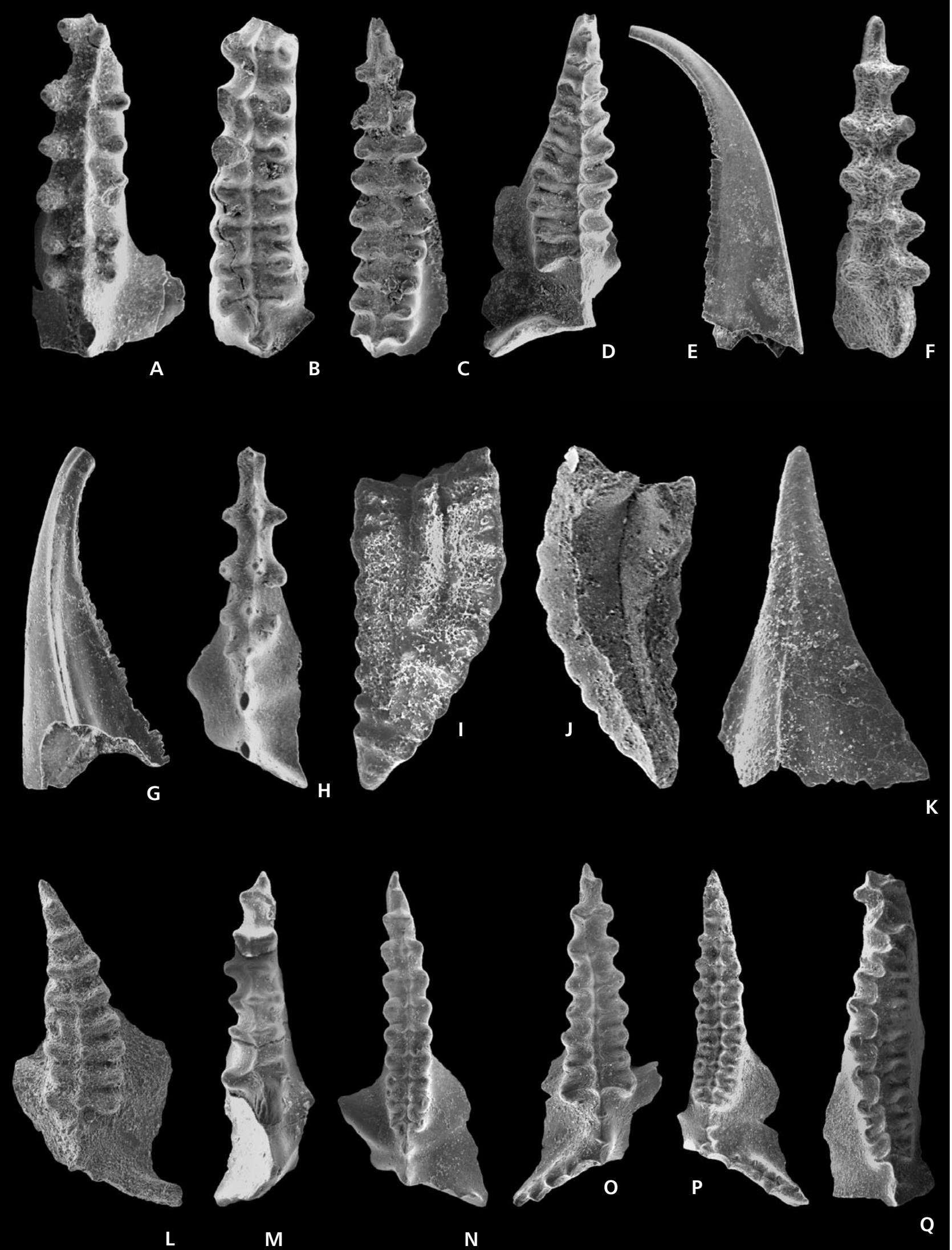

Q 

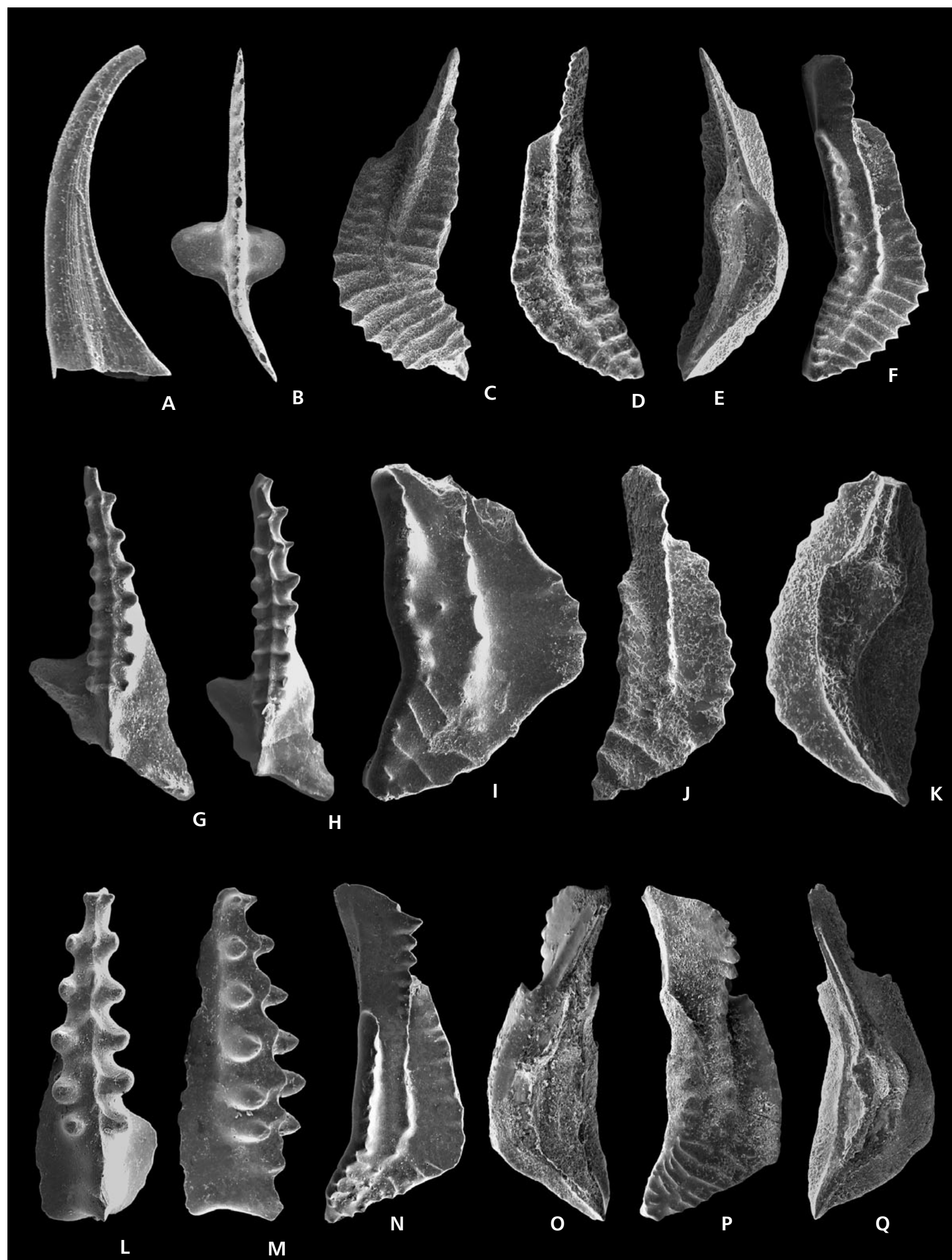

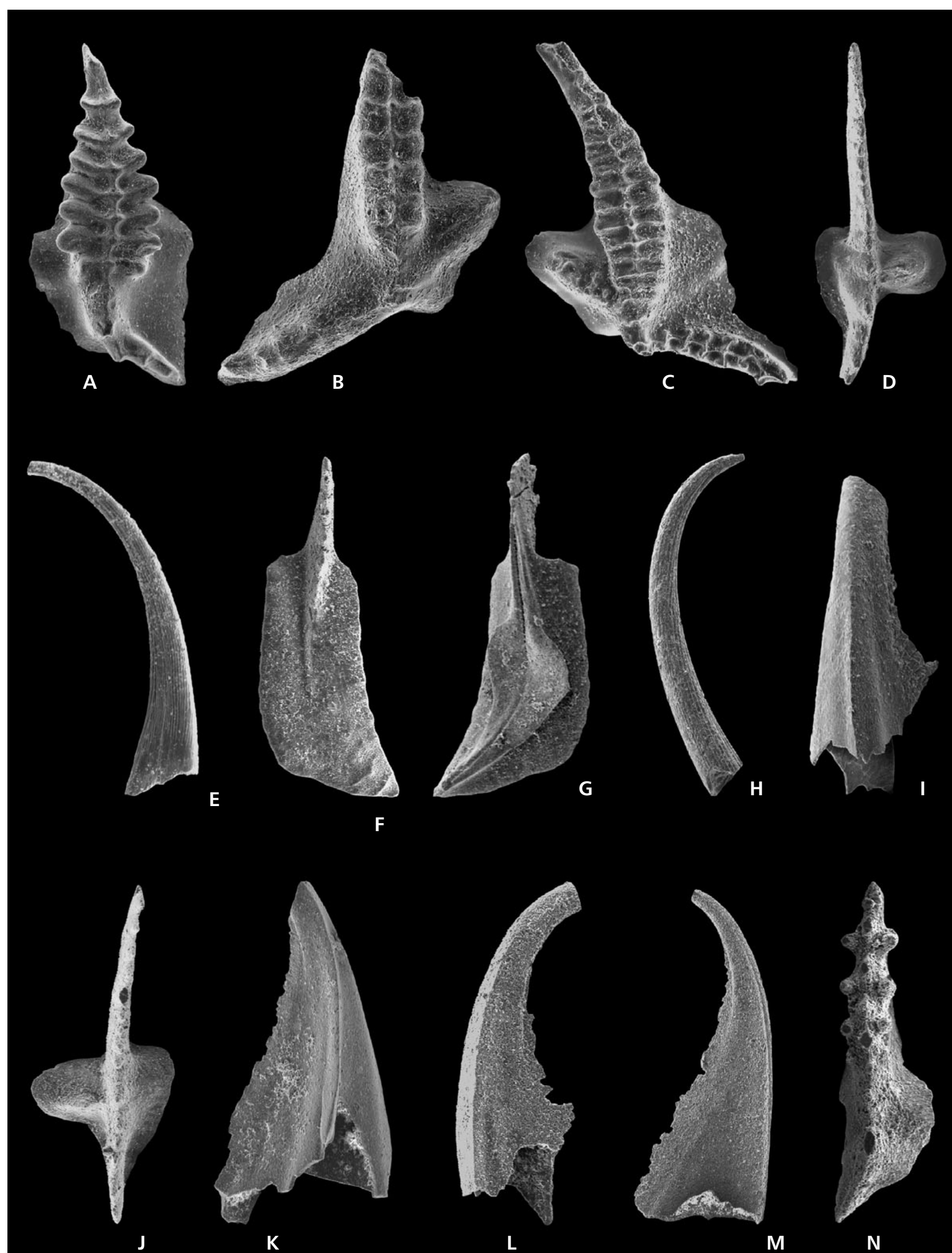

L 
The specimen of Fig. 16X (b6632) is closest to the figured type specimens of Carls \& Gandl (1969). In all three specimens of Fig. $16 \mathrm{~V}-\mathrm{X}$ the distance between the transversal denticle rows on the major part of the spindle is larger than in the type material; this suggests a different ontogeny. Specimen b6631 (Fig. 16W) resembles to some extend the mostly older Caud. curvicauda.

A small Caudicriodus from the "Latanarcestes" nodules of Rich Tamelougou has a very short terminal side lobe of the cavity platform, but not any more of the median node row. Therefore, it appears to be transitional to Icriodus s. str. and has been preliminarily identified as Caud. aff. celtibericus.

Ziegler (1975, pp. 117-119) considered Caud. celtibericus as a junior synonym of I. huddlei Klapper \& Ziegler, 1967. However, the preservation of the holotype of I. huddlei is not good enough to be used currently in precise taxonomy. The margin of the posterior part of the basal cavity is too corroded (see Ziegler 1956, pl. 6, fig. 17). Until a revision based on type material, $I$. huddlei is treated as a nom. dub.

Geographic distribution. - ?Alaska, New York State, Germany (Harz Mountains), Pyrenees, Cantabrian Mountains, Celtiberia, Ossa-Morena Zone (SW Spain), Sardinia, Moroccan Meseta, Anti-Atlas, Carnic Alps, Bohemia, Pakistan, Russian Far East.

Stratigraphic range. - Upper Pragian celtibericus Zone to high in the lower Emsian (latus Zone). Its oldest occurrence is from the upper part of the Dvorce-Prokop Limestone in the Barrandian area, below the first occurrence of Eol. excavatus (Slavík 2004a, pp. 63-66, 2004b, p. 459). The youngest records are our specimens from the upper Anetoceras Limestone of the Tafilalt.

\section{Caudicriodus aff. sigmoidalis (Carls \& Gandl, 1969)} Figure 27R

Description. - Three small icriodids from the Hollardops Limestone of Rich Tamelougou are characterized by a short, nodose outer process, which curves into a rather long posterior extension of the median row of the spindle. It is almost as long as the spindle but bears just one denticle. The spindle has only few rows, with rounded and isolated denticles.

Discussion. - The three specimens do not fit the other icriodid taxa of the same unit. They are somewhat similar to juveniles of the stratigraphically older Caud. sigmoidalis, in which, however, the side denticles are tranversally elongate and the outer process is more distinctive. The latter is more reduced in Caud. culicellus, Caud. ultimus, and
Caud. trojani, and in these three species the spindle is much longer than the posterior middle row extension. The juvenile nature of the material suggests to use open nomenclature for our form.

Stratigraphical range. - So far only known from the basal upper Emsian fusiformis Zone.

\section{Latericriodus Müller, 1962}

Type species. - Icriodus latericrescens Branson \& Mehl, 1938.

Discussion. - We use the genus Latericriodus in a wide sense, although we are aware that Lower Devonian lineages could be separated at the genus level. Such revision is beyond the scope of this paper. The type group of the genus ranges in North America from the upper Emsian to the upper Givetian (see review of icriodid ranges in Bultynck 2003).

\section{Latericriodus steinachensis (Al-Rawi, 1977)}

Figures 17A-C, E, 20D

1967 Icriodus latericrescens bilatericrescens Ziegler. Van Adrichem Boogaert, pp. 181-182, pl. 3, figs 18-20 [Morphotype eta].

1971 Icriodus latericrescens group. - Klapper \& Philip, p. 438 , fig. 8 [Morphotype eta].

*e.p. 1977 Icriodus steinachensis sp. nov.; Al-Rawi, pp. 55-56, pl. 5 , fig. 42 (holotype = Morphotype eta), 43 (paratype $=$ Morphotype beta).

1979 Icriodus steinachensis Al-Rawi. - Lane \& Ormiston, p. 54 , pl. 4, figs 28,29 [transitional between holotype and paratype].

1980 Icriodus steinachensis Al-Rawi eta morphotype. Klapper \& Johnson, p. 448, pl. 2, figs 25-27 [fig. 25 = broad submorphotype, additional synonymy].

1980 Icriodus steinachensis Al-Rawi beta morphotype. Klapper \& Johnson, p. 448, pl. 2, figs 20-22 [fig. 19 is transitional to a broad Morphotype eta; additional synonymy].

1981 Icriodus steinachensis Al-Rawi eta morphotype. Johnson \& Klapper, pl. 1, figs 15, 16 [figs 18, $19=$ Klapper \& Johnson 1980, pl. 1, fig. 25, is a broad submorphotype].

1983 Icriodus steinachensis Al-Rawi. - Murphy \& Matti, p. 58, pl. 5, fig. 31 (Morphotype beta), fig. 36 (Morphotype eta).

1984 Icriodus steinachensis Al-Rawi. - Murphy \& Cebecioglu, figs 2a-r, z-hh, 5g-q [typical Morphotype beta $=2 \mathrm{~h}, \mathrm{z}-\mathrm{cc}, \mathrm{ff}, \mathrm{hh}, 5 \mathrm{~g}, \mathrm{~h}, \mathrm{j}, \mathrm{n}$, slender beta submorphotype $=2 \mathrm{a}, \mathrm{c}-\mathrm{e}, \mathrm{gg}, 5 \mathrm{o}, \mathrm{p}$, typical Morpho- 


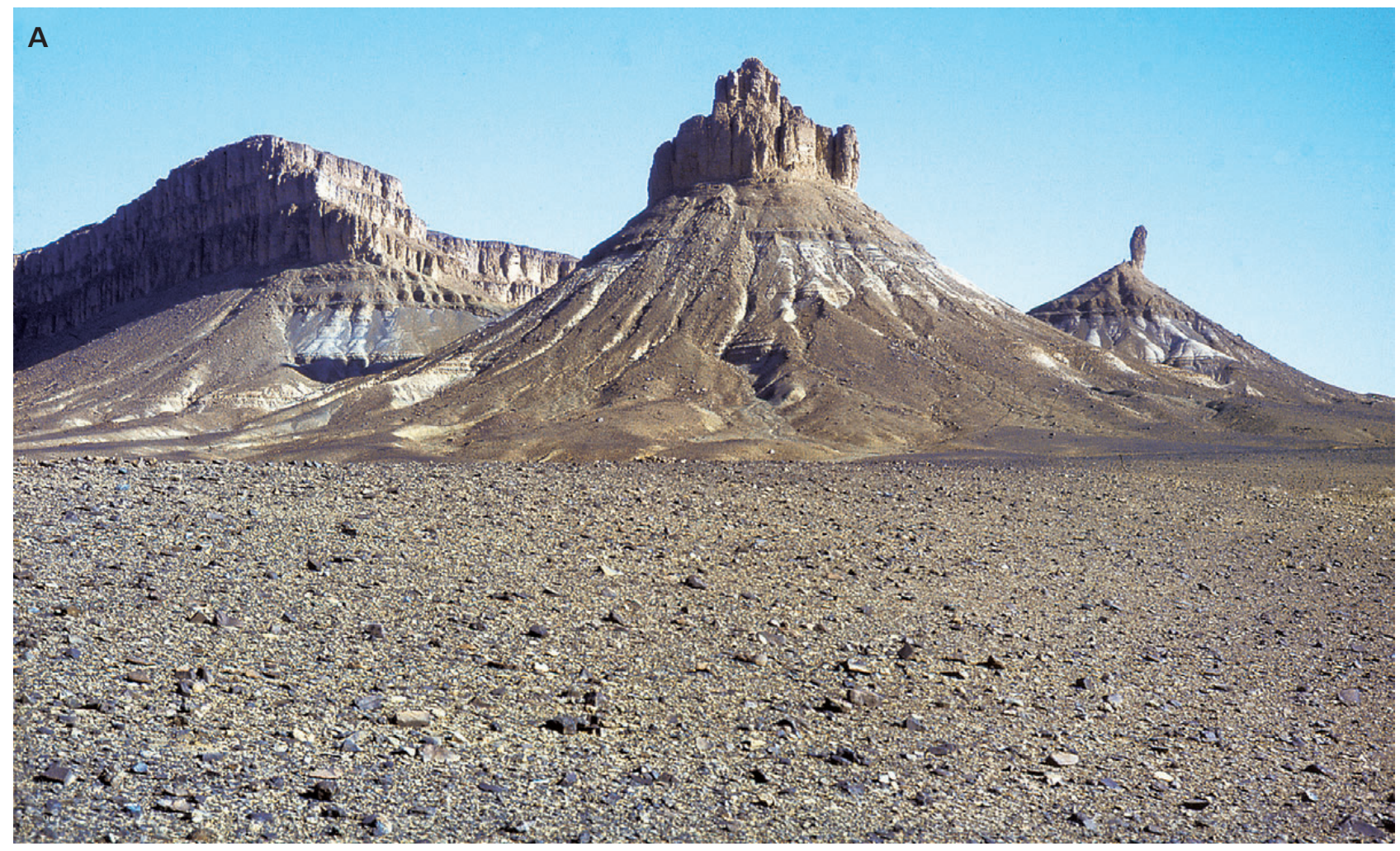

Figure 23. Emsian outcrops at Mdâouer-el-Kbîr (A) and El Anhsour (B) in the eastern Dra Valley.

type eta $=2 \mathrm{~b}, \mathrm{f}, \mathrm{k}-\mathrm{r}$, ee, $5 \mathrm{q}$, broad eta submorphotype $=2 \mathrm{~g}, \mathrm{i}, \mathrm{j}, \mathrm{dd}, 5 \mathrm{i}, \mathrm{k}]$.

e.p. 1985 Icriodus steinachensis Al-Rawi beta morphotype. Chlupáč, Lukeš, Paris \& Schönlaub, pl. 2, fig. 4 (only).

1994 Icriodus steinachensis Al-Rawi. - Valenzuela-Ríos, pl. 8, figs 5, 7, 8, 11 .

1994 Icriodus steinachensis Al-Rawi eta morph. - Mawson \& Talent, pp. 47, 49, figs 9k-n.

1995 Icriodus steinachensis Al-Rawi eta morph. - Dongal, p. 137, figs 5a, b [transitional to Morphotype beta].

? 1999 Icriodus steinachensis Al-Rawi eta morph. - Talent \& Mawson, p. 73, pl. 4, fig. 6, pl. 7, figs 5, 6, pl. 12, fig. 17 [all fragmentary].

2001 Latericriodus steinachensis Al-Rawi eta morph. Slavík, pl. 2, fig. 4.

2002 Icriodus steinachensis Al-Rawi beta. - Valenzuela-Ríos, pp. 416-417, pl. 2, fig. 2 [slender submorphotype, transitional to Morphotype eta].

2004a Latericriodus steinachensis Al-Rawi beta. - Slavík, figs 3.1, 3.14 (slender submorphotypes), fig. 3.13 (here re-assigned as Morphotype eta).

2004a Latericriodus steinachensis Al-Rawi eta. - Slavík, figs 3.2-3.4.

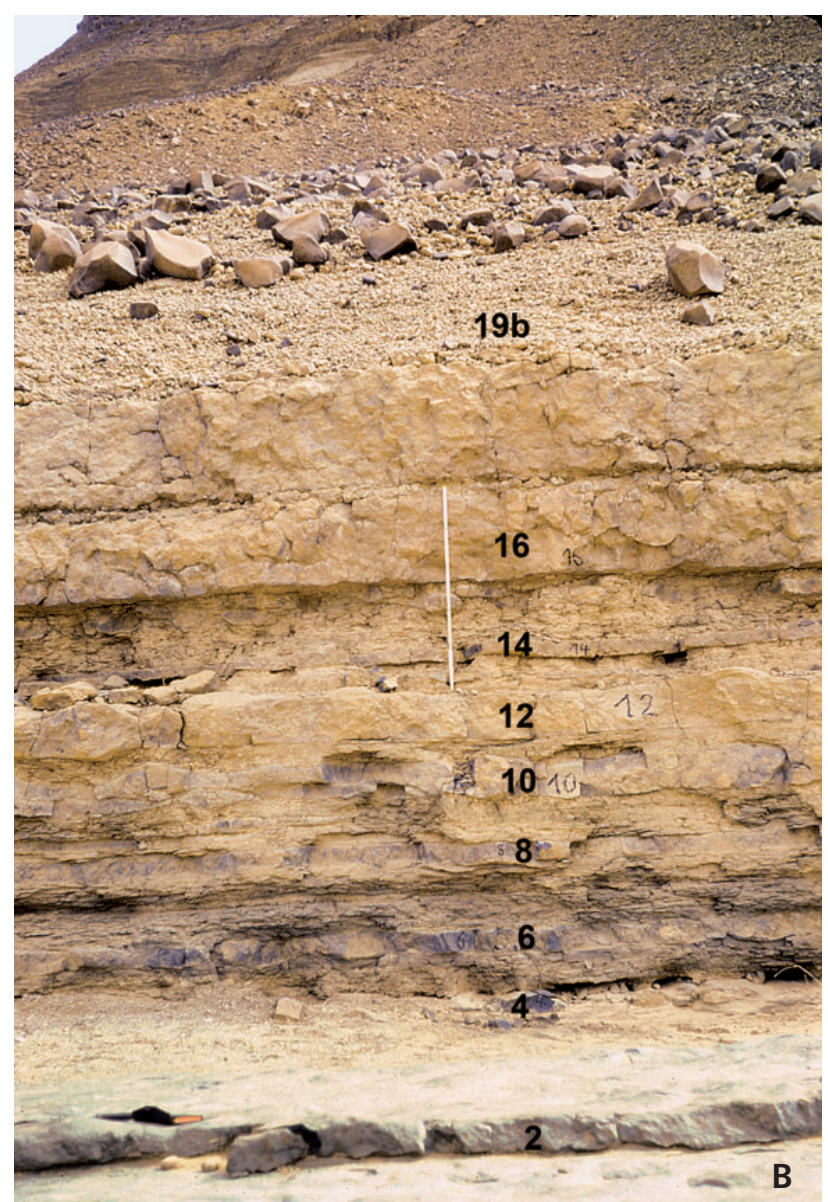




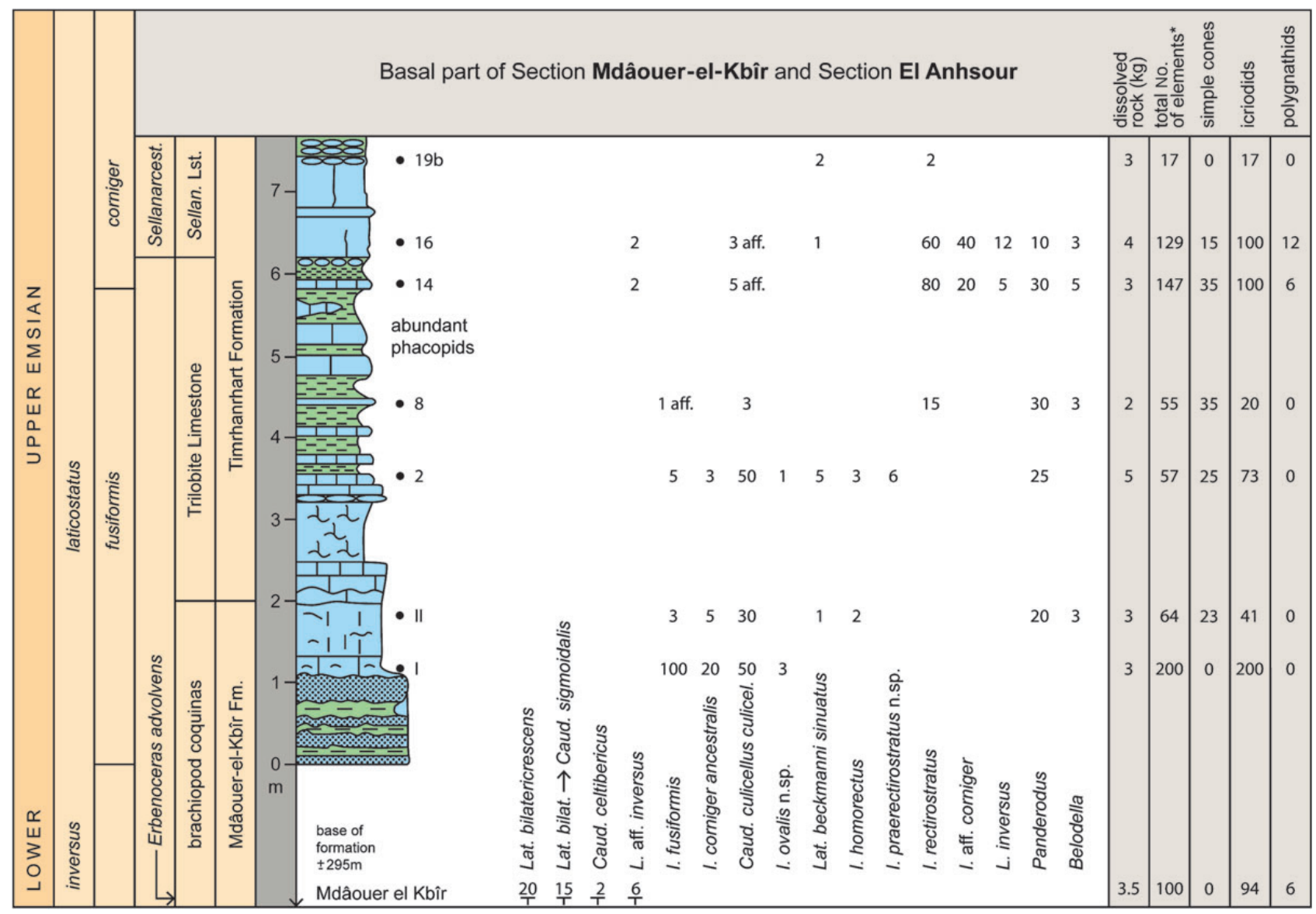

Figure 24. Lithological succession, sample positions, and conodont ranges at El Anhsour (eastern Dra Valley).

2004b Latericriodus steinachensis Al-Rawi beta. - Slavík, pl. 1, fig. 4 [here re-considered as Morphotype eta].

2004b Latericriodus steinachensis Al-Rawi eta. - Slavík, pl. 1, fig. 5 .

2004 Latericriodus steinachensis Al-Rawi eta morph. Slavík \& Hladil, pp. 144-145, pl. 1, figs 2-4 [wide and narrow submorphotypes but fig. 4 is a juvenile].

2004 Latericriodus steinachensis Al-Rawi beta morph. Slavík \& Hladil, p. 145, pl. 1, figs 2-4 [spindle not very curved].
2012 Caudicriodus? steinachensis Al-Rawi eta morphotype of Klapper \& Johnson, 1980. - Drygant \& Szaniawski, pp. 850, 852, fig. $11 \mathrm{~m}$ [with additional and partly different synonymy].

Discussion. - In the holotype of Lat. steinachensis the spindle is rather slender and the posterior part of the basal cavity is not much expanded. In the paratype the spindle is shorter and broader and the posterior part of the basal cavity is expanded. However, many characteristics are the

Figure 25. Conodonts from the upper Emsian of El Anhsour of the eastern Dra Valley; A-V - the fusiformis Zone; W-AC - beds with I. aff. corniger, ca corniger Zone, all × 47. • A-D - I. fusiformis Carls \& Gandl, 1969. Sample I, upper Mdâouer-el-Kbîr Formation; A - outer lateral view of b6667; B - upper view of b6668; C - upper view of b6669; D - lower view of b6670. • E-G - I. ovalis sp. nov. Sample I, upper Mdâouer-el-Kbîr Formation; E - outer lateral view of paratype b6671; F - upper view of holotype b6672; G - upper view of paratype 6673. • H, I - I. corniger ancestralis Weddige, 1977. Sample II, top Mdâouer-el-Kbîr Formation; H - upper view of b6674; I - lower views of b6675. • J-L - Caud. culicellus culicellus Bultynck, 1976. Sample II, top Mdâouer-el-Kbîr Formation; J - upper view of b6676; K - outer lateral view of b6677; L - outer lateral view of b6678. - M-P - I. homorectus Weddige, 2003. Sample II (as 8-12); M - upper view of b6679; N - outer lateral view of b6680; O, P - lower and upper views of b6681. - Q, R - I. praerectirostratus sp. nov. Sample 2, basal Timrhanrhart Formation, lower and upper views of holotype b6682. - S-X - I. praerectirostratus sp. nov. Type level (Sample 2); S - upper view of paratype b6683; T - upper view of paratype b6684; U - upper view of paratype 6685; V - upper view of paratype b6686; W, X - lower and upper views of paratype b6687. • Y - Latericriodus beckmanni sinuatus (Klapper, Ziegler \& Mashkova, 1978). Upper view of fragmentary b6688, Sample 19b, Sellanarcestes Limestone Member. • Z, AA - L. aff. inversus (Klapper \& Johnson, 1975). Specimen with extensive lingua and subsymmetric basal pit, b6689, Sample 14, top of Trilobite Limestone. • AB, AC - L. inversus (Klapper \& Johnson, 1975). Typical specimen with short, semi-crossed lingua, b6690, Sample 14, top of Trilobite Limestone. 


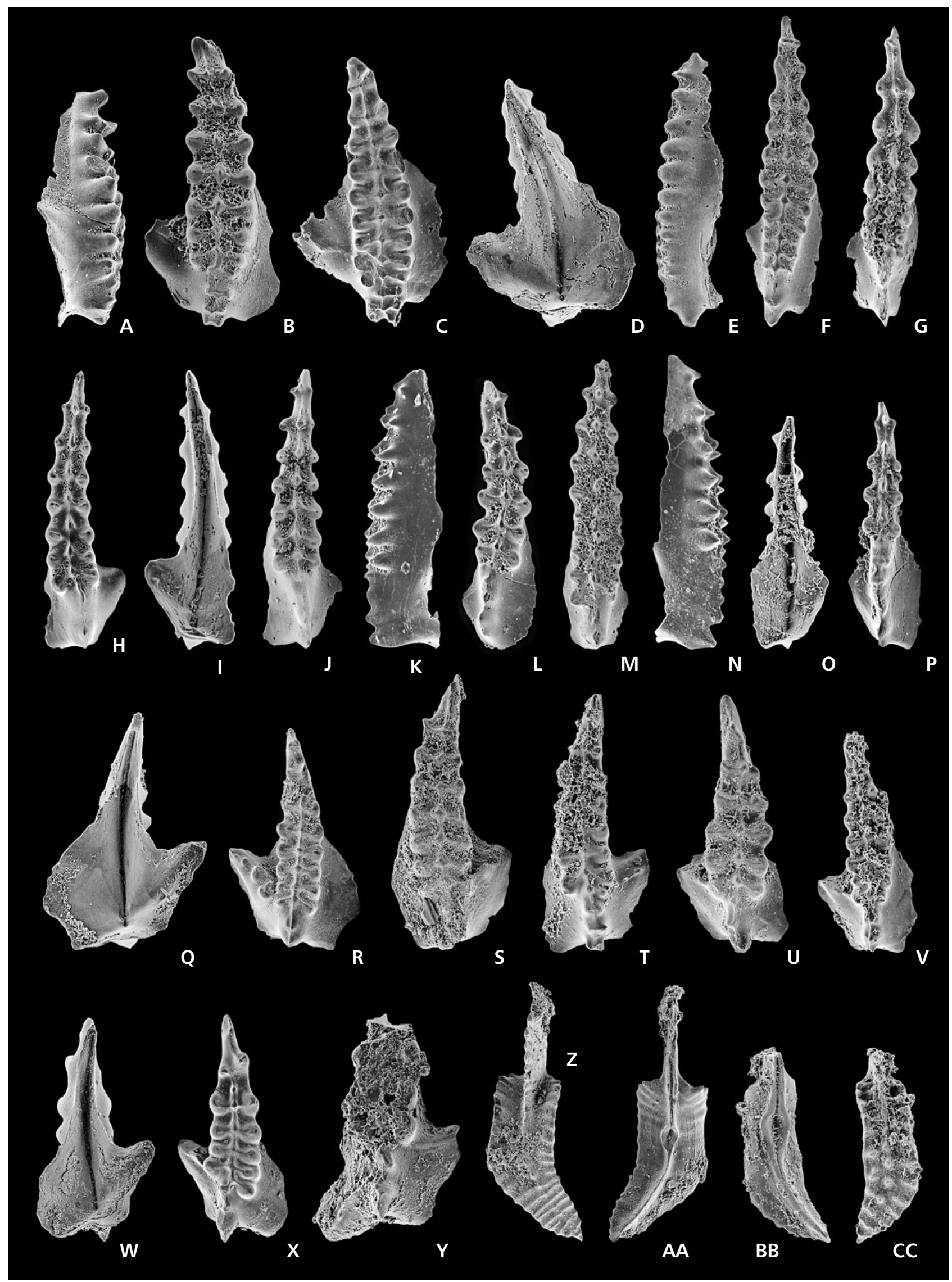


same in both type specimens: the outline of the spindle is clearly concavo-convex; the axis of the element is distinctly curved, the cross-sections of the denticles on the spindie are rounded, the middle and lateral rows denticles are not fused, and the outer lateral, posterior process joins the extension of the middle row denticles just before its end. Klapper \& Johnson (1980) distinguished beta and eta morphotypes corresponding mostly to the paratype and the holotype as originally established by Al-Rawi (1977). However, they defined both morphotypes on the position of the maximum spindle width, not on the distinction between slender and broad forms. Consequently, there are wide and narrow forms (submorphotypes) within both named morphotypes (see our new synonymy list above). The morphometric study of Murphy \& Cebecioglu (1984) suggests a large intraspecific variability, but with morphological trends through time. Biostatistics from other regions should test the possibility that the morphotypes represent different subspecies, with different distributions in time and space.

In the material from Bou Tchrafine North (Fig. 17C) Lat. steinachensis sensu the holotype (eta morphotype) occurs in the upper Pragian. The Pragian specimens from El Khraouia include rather elongate forms of Morphotype beta with hardly curved spindle (Fig. 20D). Murphy \& Cebecioglu (1984) illustrated a similar specimen in their fig. 5P, Dongal (1995) in his fig. 5B. In lower Emsian specimens from BTN the longitudinal axis of the element is also less curved than in the holotype (Fig. 17A, B, E). We regard such straight forms currently as intraspecific variants although they could be assigned to a late third morphotype, which is close to the narrow forms transitional between Morphotypes eta and beta. The taxonomic position of this form should be re-evaluated when more material becomes available.

Stratigraphic range. - The entry of Lat. steinachensis, especially of Morphotype eta, is used to approximate the base of the Pragian in its type region (Slavík \& Hladil 2004), where both morphotypes range into the serratus Zone. Here we extend the upper range into the basal Emsian Eol. excavatus M114 Zone or bilatericrescens bilatericrescens Zone (upper Deiroceras Limestone) but this is based on atypically straight specimens.

\section{Latericriodus sp. nov.}

Figure 18S-U

Description. - A single slender Latericriodus from Sample BTN P/E2 has a narrow spindle with six rows that are more closely spaced posteriorly. The denticles are coarse in the anterior part and small in the last three rows. The denticles of the posterior middle row are smaller and there are three nodes on the median extension of the spindle. The outer lateral process joins the last denticle of the median row at a right angle and possesses two nodes. The cavity extension has a triangular outline and is restricted to the area between the posterior third of the platform and the pointed tip of the outer process.

Discussion. - The morphology differs from that in all named Pragian Latericriodus species but since there is only one available specimen open nomenclature is used.

Stratigraphic range. - Regional Lat. steinachensis Zone, Pragian.

Figure 26. Lithology and position of conodont samples in the lower Emsian of Bou Tserfine (western Dra Valley). For additional symbols see Fig. 4.

Figure 27 (page 964). Conodonts from the Emsian of the western Dra Valley; A-C - Bou Tserfine, Bed A10b, Akhal Tergoua Member, Lat. latus Zone with Lat. beckmanni; D - Bou Tserfine, Sample D1, basal Hollardops Limestone, local bilatericrescens Ecozone; E, F, H-K, M, O-R - Rich Tamelougou, main sample of Hollardops Limestone, fusiformis Zone with I. cf. rectirostratus and Caud. culicellus culicellus; G, L, N - Rich Tamelougou, basal Akhal Tergoua Member, latus Zone with Lat. beckmanni. • A - Lat. beckmanni beckmanni (Ziegler, 1956). B9.A-5.78, × 65. - B - Caud. cf. ultimus Weddige in Weddige \& Requadt, 1985. Specimen without curvature of the posterior middle row of denticles, transitional to Icriodus s. str., B9.A-5.79, $\times 70 . \bullet \mathrm{C}-$ Caud. sigmoidalis (Carls \& Gand1, 1969). B9.A-5.80, $\times 85$. $・ \mathrm{D}-$ Lat. bilatericrescens bilatericrescens (Ziegler, 1956). Intermediate to bilatericrescens multicostatus (Carls \& Gandl, 1969), B9.A-5.81, $\times 50$. E - I. cf. werneri Weddige, 1977. With fewer denticle rows and thicker denticles of side rows that are connected with the middle row than in typical representatives, B9.A-5.82, $\times 85$. $\bullet \mathrm{F}-\mathrm{Caud}$. ultimus Weddige in Weddige \& Requadt, 1985. More typical small specimen with slightly sinuose posterior extension of the middle denticle row, B9.A-5.83, $\times 120 . \bullet \mathrm{G}-$ Lat. beckmanni ?sinuatus (Klapper, Ziegler \& Mashkova, 1978). B9.A-5.84, $\times 85 . \bullet \mathrm{H}-\mathrm{K}-$ Caud. culicellus culicellus Bultynck, 1976 . Two juvenile specimens with still few denticle rows; H, I - upper and outer oblique views of B9.A-5.85, $\times 200 ; \mathrm{J}, \mathrm{K}-\mathrm{upper}$ and inner oblique view of B9.A-5.86, $\times 150$. $\bullet$ L - Eol. excavatus (Carls \& Gand1, 1969) Morphotype 114. Fragmentary specimen, B9.A-5.87, $\times 130$. $・$ M - I. corniger leptus Weddige, 1977, B9.A-5.88, × 75. • N, O - Neop. perlineatus Ziegler \& Lindström, 1971; N - Akhal Tergoua Member, B9.A-5.89, × 100; O - Hollardops Limestone Member, B9.A-5.-90, × 70. • P - I. cf. rectirostratus Weddige, 1977. B9.A-5.91, $\times 85 . \bullet$ Q - Bel. resima (Philip, 1965). B9.A-5.92, $\times 85 . \bullet \mathrm{R}-$ Caud. aff. sigmoidalis (Carls \& Gand1, 1969). Small specimen with long straight ridge between median row and its curved posterior extension, B9.A-5.93, $\times 120$. 
Zhor Sarah Aboussalam et al. • Emsian (Lower Devonian) conodont stratigraphy and correlation of the Anti-Atlas

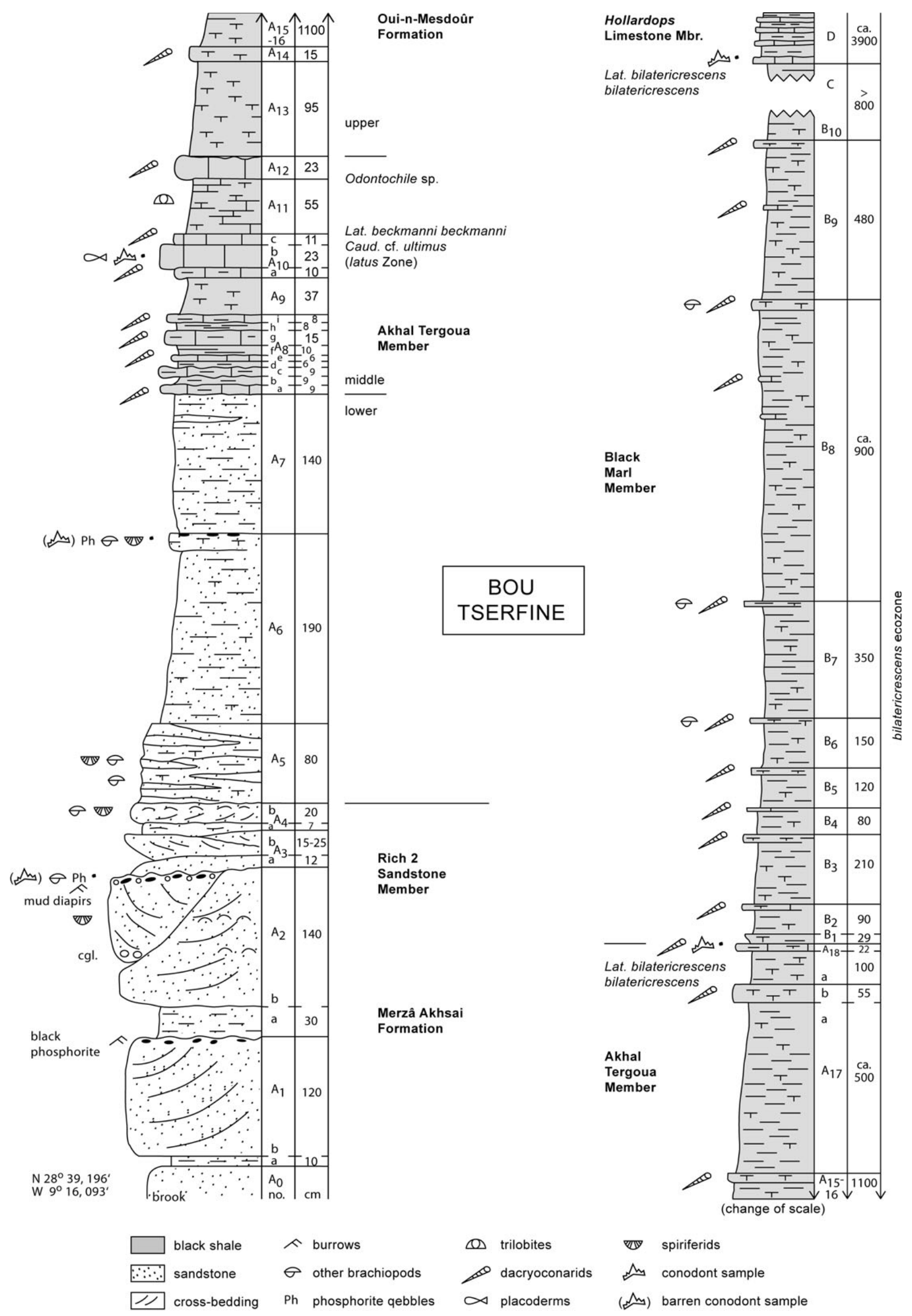



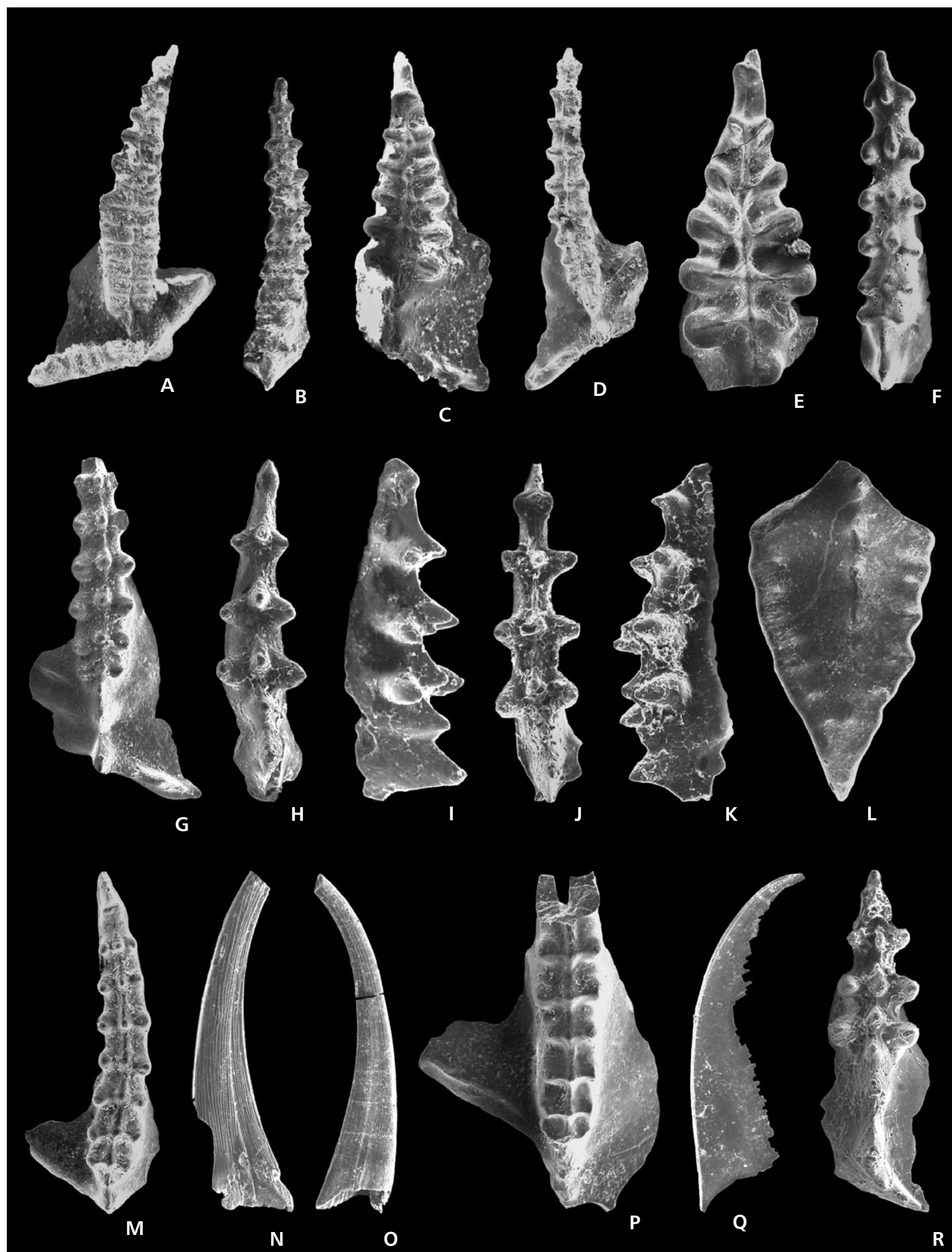

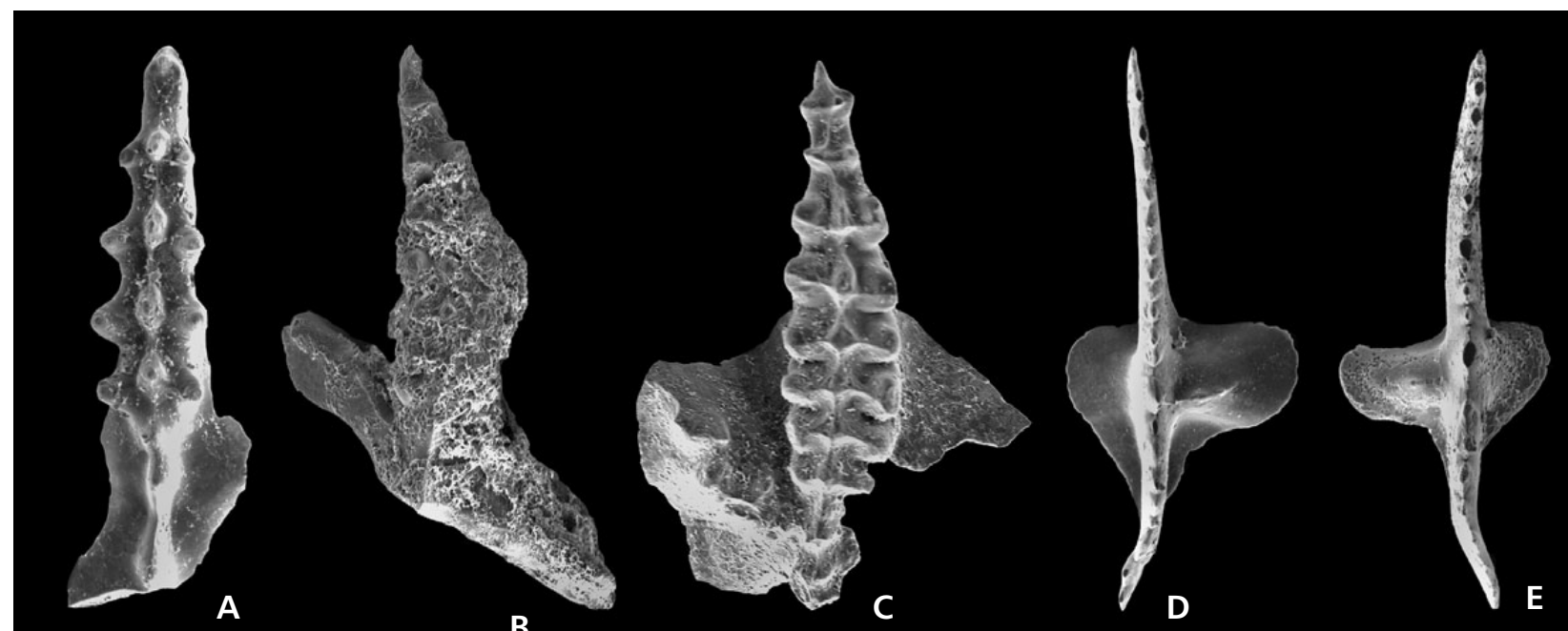

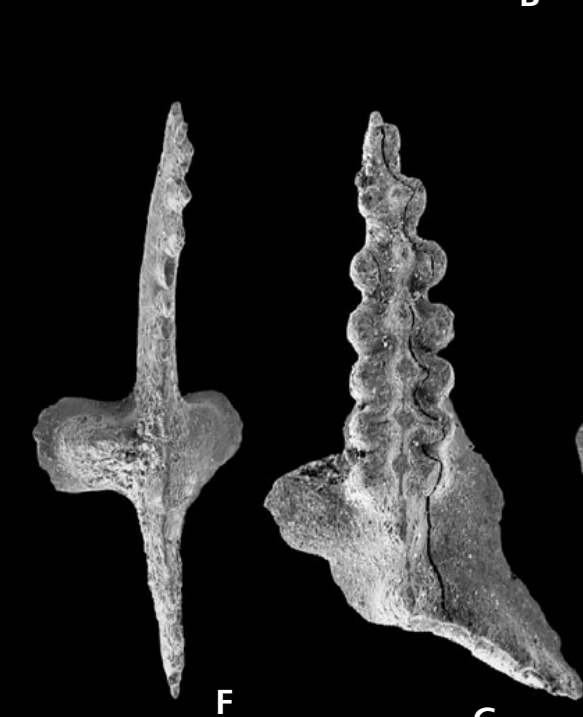

F

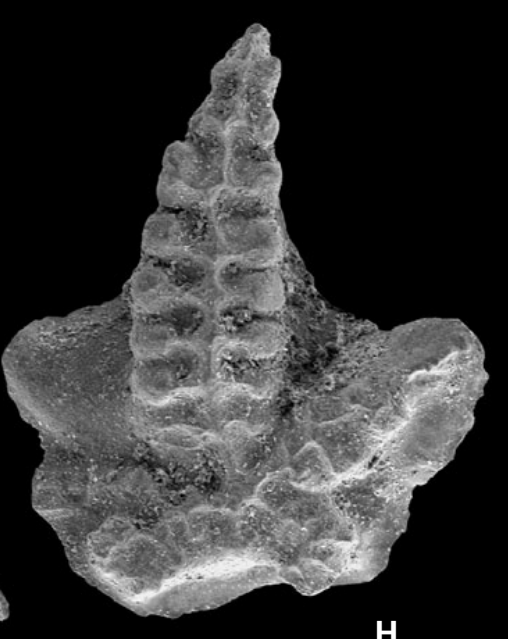

H
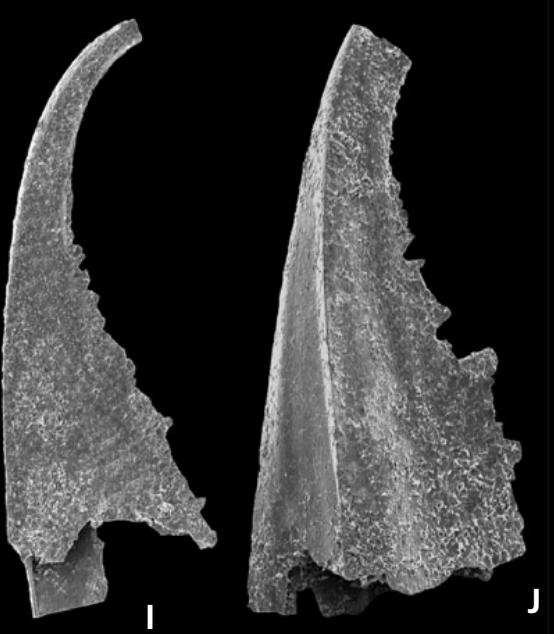

Figure 28. Lower Emsian conodonts from dissolved goniatites of the Anetoceras Limestone, latus Zone (with Lat. beckmanni) or steinhornensis Zone; A-F - Bou Tchrafine, Sample BT-Kl, several dissolved Klugites gesinae gen. nov.; G-J - Ouidane Chebbi, Sample OCh-Anet, block with Anet. cf. obliquicostatum. • A - juvenile Caud. celtibericus (Carls \& Gandl, 1969). B9.A-5.94, posterior end broken, $\times 100 . \cdot$ B, G - Lat. bilatericrescens bilatericrescens (Ziegler, 1956); B - poorly preserved, B9.A-5.95, ×60; G - B9.A-5.96, ×65. • C, H - Lat. beckmanni beckmanni (Ziegler, 1956); C - incomplete, B9.A-5.97, $\times 65 ; \mathrm{H}-$ typical specimen, B9.A-5.98, $\times 60$. $・ \mathrm{D}-\mathrm{F}-$ Crit. steinhornensis (Ziegler, 1956); D - specimen with thin ridge on the outer lobe and triangular posterior platform extension, B9.A-5.99, $\times 75 ; \mathrm{E}-$ specimen with small node on the outer lobe, B9.A-5.100, $\times 85$; F - B9.A-5.101, $\times 60 . \bullet \mathrm{I}-$ Bel. resima (Philip, 1965). B9.A-5.102, × 60. $\bullet \mathrm{J}-$ Bel. triangularis (Stauffer, 1940). B9.A-5.103, × 60 .

Latericriodus bilatericrescens bilatericrescens (Ziegler, 1956)

Figures 7A, B, 8B-E, 9F, 17F, G, 22B, 27D, 28B, G

* 1956 Icriodus latericrescens bilatericrescens sp. nov.; Ziegler, pp. 101-102, pl. 6, figs 6-11.

1979 Latericriodus bilatericrescens bilatericrescens (Ziegler). - Bultynck, pl. 2, figs 10, 11.

1979 Latericriodus subsp. B; Bultynck, pl. 2, fig. 12.

1980 Icriodus bilatericrescens Ziegler. - Klapper \& Johnson, pl. 2, figs 13-16. e.p. 1980 Latericriodus bilatericrescens (Ziegler) subsp. A. Bultynck \& Hollard, pl. 1, fig. 13 (only).

e.p. 1980 Latericriodus bilatericrescens bilatericrescens (Ziegler). - Bultynck \& Hollard, pl. 1, fig. 14 [figs 15-21 = multicostatus, figs 22-24 = gracilis].

1981 Icriodus bilatericrescens Ziegler. - Johnson \& Klapper, p. 1241, pl. 1, fig. 7.

1985 Latericriodus bilatericrescens bilatericrescens (Ziegler). - Bultynck, pl. 5, figs 9, 10 (only).

1989 Latericriodus bilatericrescens bilatericrescens (Ziegler). - Bultynck, pl. 7, figs 13-15. 


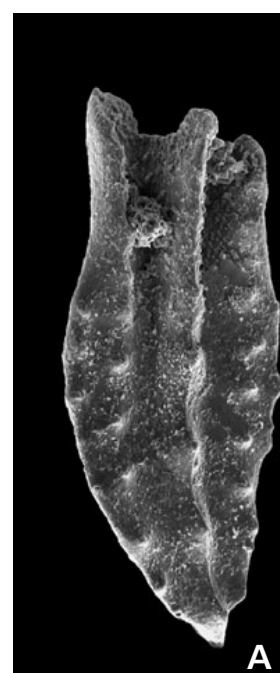

A

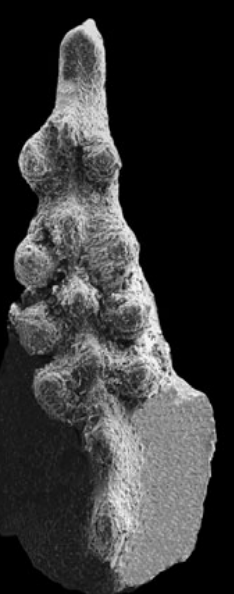

H

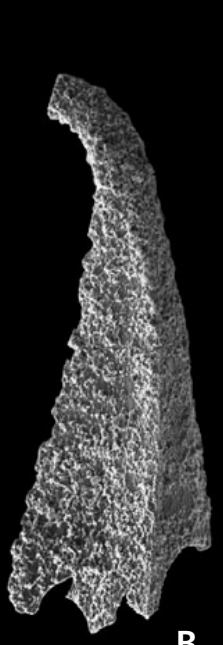

B

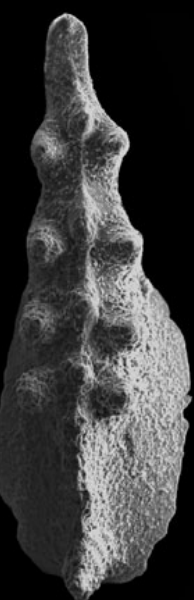

I
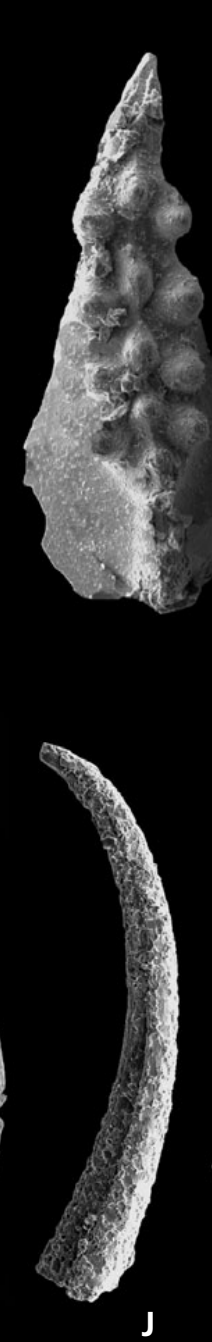

C

D

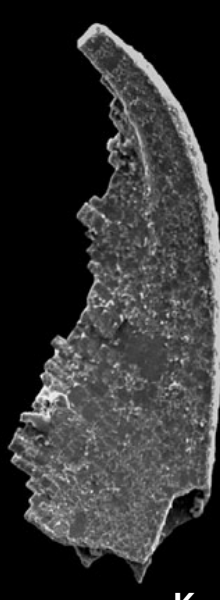

K

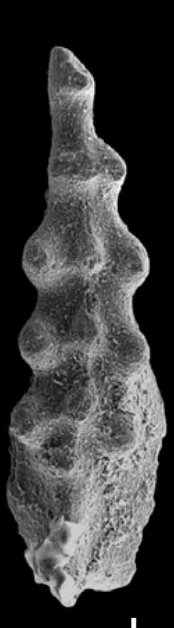

L

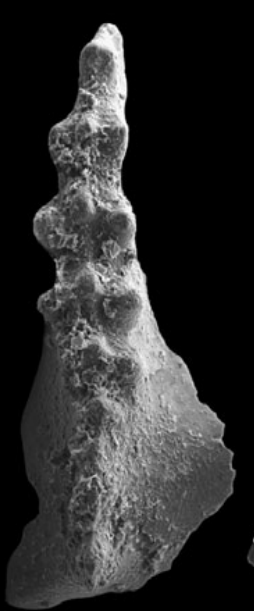

M

Figure 29. Upper Emsian conodonts from dissolved anarcestids of the Anti-Atlas; A-J, N-Tafilalt, Anarcestes Limestone; K, L - eastern Dra Valley, Sellanarcestes Limestone, Oufrane West, Bed 11, fusiformis Zone with Caud. culicellus culicellus; M - western Dra Valley, Rich Tamelougou, "Latanarcestes" nodules of the Brachiopod Marl Member, upper fusiformis Zone. • A - Po. costatus patulus Klapper, 1971. Fragmentary, small specimen, B9.A-5.104, Sample OCh-An, patulus Zone, $\times 140$. • B, E, K - Bel. resima (Philip, 1965); B - B9.A-5.105, Sample EKs-D, ?corniger Zone (locally without diagnostic icriodids), × 80; E - B9.A-5.106, EKs-B, ?corniger Zone, × 75; K - B9.A-5.107, Sample Ouf-Sell, $\times 115$. $・$ C, D, H, I, L - Caud. culicellus culicellus (Bultynck, 1976); C - B9.A-5.108, Sample EKs-D, $\times$ 95; D - juvenile, B9.A-5.109, Sample EKs-D, $\times 115$; H - wide morphotype, B9.A-5.110, Sample EKs-B, $\times 100$; I - narrow morphotype, B9.A-5.111, Sample EKs-B, $\times 120 ;$ L - B9.A-5.112, Sample Ouf-Sell, $\times 80$. • F, G, J, N Neop. perlineatus Ziegler \& Lindström, 1971; F - B9.A-5.113, Sample EKs-D, × 60; G - B9.A-5.114, Sample EKs-B, × 75; J - B9.A-5.115, Sample EKs-B, $\times 60$; N - B9.A-5.116, Sample EKs-B, × 75. • M - Caud. aff. celtibericus (Carls \& Gandl, 1969). Transitional to Icriodus s. str., B9.A-5.117, $\times 100$.

Figure 30. Comparison of Emsian conodont zonations for different faunal groups (polygnathids, icriodids, spathognathodids) and different regions (Tafilalt, Maider, western and eastern Dra Valley) of the Anti-Atlas, correlated with the Conodont Steps sensu Carls 1999 and Carls \& Valenzuela-Ríos (2002). Roman numbers in () refer to the previously numbered zones of Bultynck \& Hollard (1980) and Bultynck (1985), showing the successions where they have been recognized originally. C-numbers refer to the Dra Valley conodont faunas of Jansen et al. (2007).

Figure 31 (page 968). Stratigraphic ranges of conodont taxa and morphotypes in the upper Pragian to basal Eifelian of the Anti-Atlas, based on literature data and the new record. Ranges are plotted against the Tafilalt lithostratigraphy. 
Zhor Sarah Aboussalam et al. • Emsian (Lower Devonian) conodont stratigraphy and correlation of the Anti-Atlas

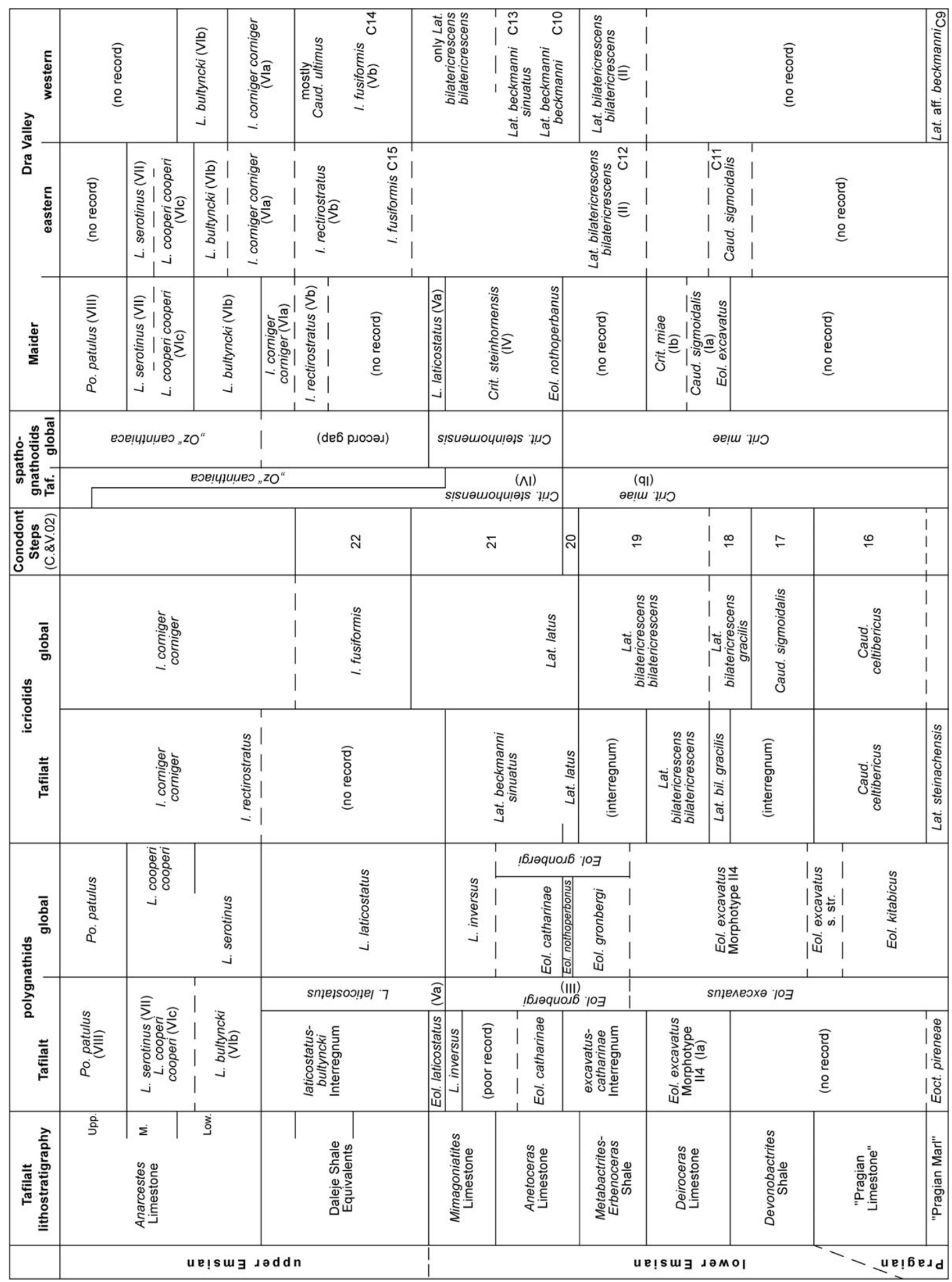


Bulletin of Geosciences • Vol. 90, 4, 2015

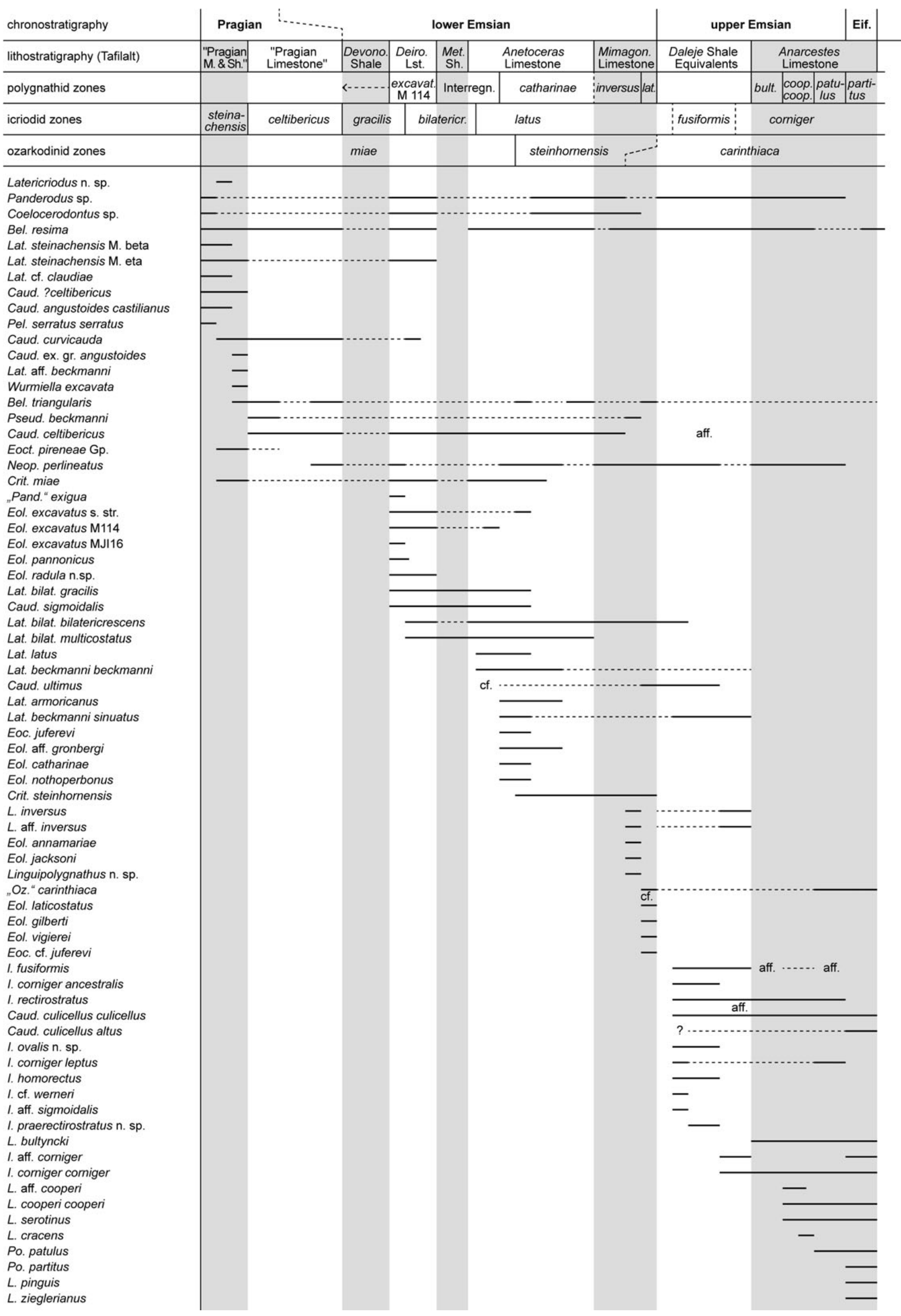


Zhor Sarah Aboussalam et al. • Emsian (Lower Devonian) conodont stratigraphy and correlation of the Anti-Atlas

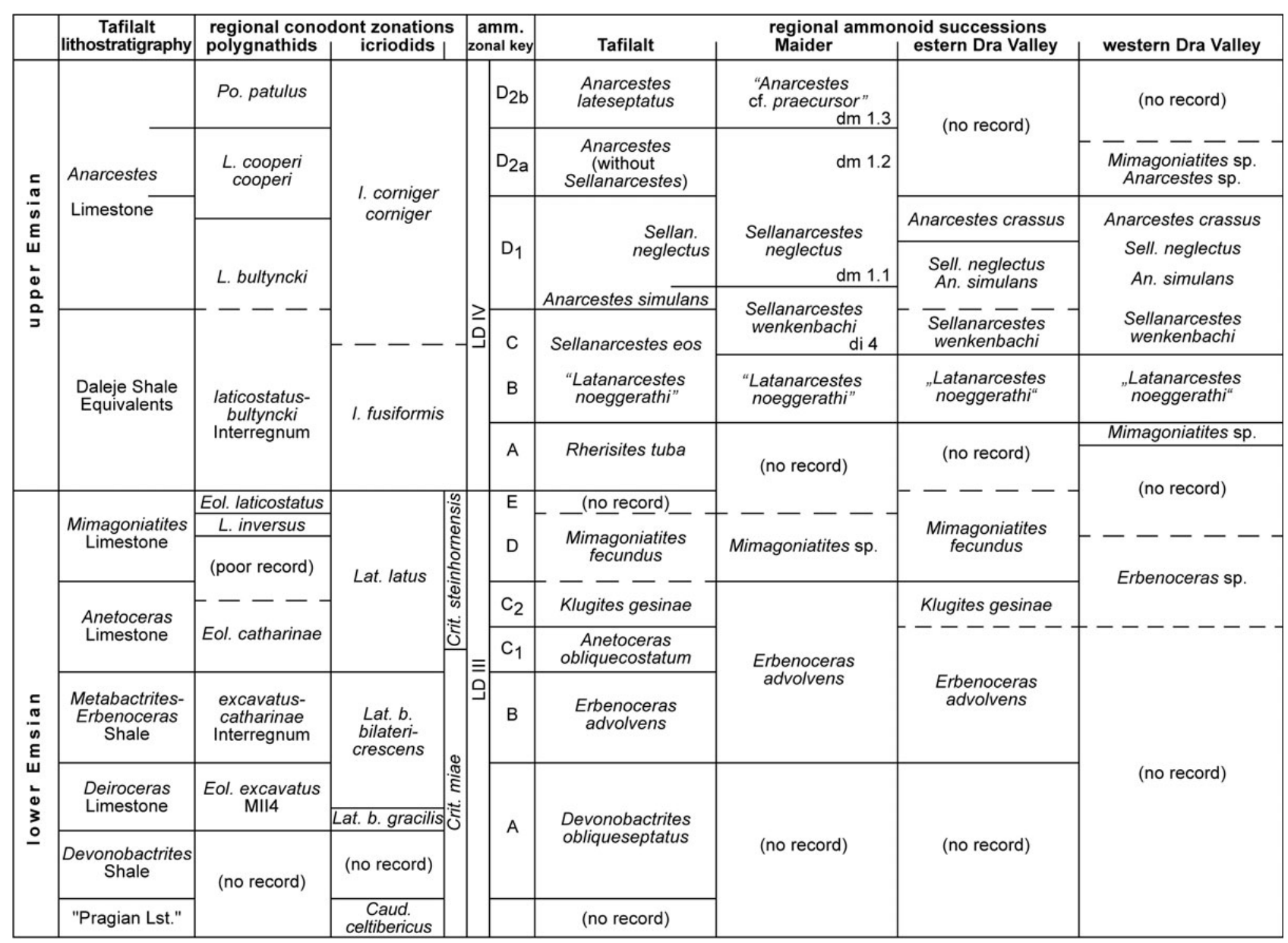

Figure 32. Correlation of the Tafilalt conodont and ammonoid zonation and alignment with goniatite levels of the Maider and Dra Valley. Ammonoid zonal key updated from Becker \& House (1994) and Becker et al. (2012). Zonal numbers di 4 to dm 1.3 refer to the numbering in Hollard (1974).

1990 Latericriodus bilatericrescens bilatericrescens (Ziegler). - Olivieri \& Serpagli, p. 60, pl. 1, fig. 11 [fig. 17 = supposed Pb element].

1994 Latericriodus bilatericrescens bilatericrescens (Ziegler). - García-López \& Alonso-Menendez, pl. 3, figs 2, 3, 6 .

e.p. 1995 Latericriodus bilatericrescens (Ziegler). - Kalvoda, pp. 36-37, pl. 1, figs 2, 6, pl. 2, figs 5, 7 [including transitional forms towards multicostatus; synonymy for all subspecies].

2001 Latericriodus bilatericrescens bilatericrescens (Ziegler). -Slavík, p. 262, pl. 3, fig. 6, pl. 4, fig. 2.

2002 Latericriodus bilatericrescens bilatericrescens (Ziegler). - García-López, Jahnke \& Sanz-López, p. 252, pl. 3, figs 21, 22 .

2003 Latericriodus? bilatericrescens bilatericrescens (Ziegler). - Bultynck, pl. 2, figs 9-12 [re-illustration of specimen from Bultynck 1979].

2004a Latericriodus bilatericrescens bilatericrescens (Ziegler). - Slavík, pp. 465-466, figs 11.13, 11.14. 2004a Latericriodus bilatericrescens cf. bilatericrescens (Ziegler). - Slavík, pp. 465-466, fig. 11.15 [fig. 11.16 is very fragmentary].

Discussion. - The holotype of Icriodus latericrescens bilatericrescens (Ziegler 1956, pl. 6, figs 8, 9) differs somewhat from the other figured specimens, which are not from the type region. In the holotype the lateral row denticles are slightly elongate transversally and slightly connected with the middle row denticles. In the two other original specimens the lateral row denticles are clearly round and less connected with the middle row denticles, which are also larger than in the holotype. The most diagnostic features are given in Johnson \& Klapper (1981, p. 1241): "Specimens of Icriodus bilatericrescens are characterized by a longer inner spur, which is characteristically ornamented by a ridge that may be denticulated. The spur is on line with the outer lateral process. The longitudinal spacing of lateral-row denticles is essentially uniform as opposed to the spacing in I elements of I. nevadensis." 
Apart from typical forms there are intermediates towards the other subspecies, which have more denticle rows and which are more slender. Specimens B9.A-5.11-12 (Fig. 7A, B) and b6638 (Fig. 17F) are transitional from gracilis, specimen B9.A-5.81 (Fig. 27D) shows a trend towards multicostatus. As noted in Kalvoda (1995) there are specimens, which do not fall clearly in any of the three recognized subspecies. The numerous transitions speak against a full species separation of these.

Stratigraphic range. - Lower Emsian bilatericrescens bilatericrescens Zone to basal upper Emsian fusiformis Zone (e.g., at Rich Tamelougou).

Latericriodus bilatericrescens gracilis Bultynck, 1985 Figures 5G, H, 17H-J, 21G, H

e.p. 1980 Latericriodus bilatericrescens bilatericrescens (Ziegler). - Bultynck \& Hollard, pl. 1, fig. 22 (only fig. 23 = holotype).

* 1985 Latericriodus bilatericrescens gracilis n. subsp.; Bultynck, p. 269, pl. 5, figs 1, 2.

1990 Icriodus bilatericrescens gracilis (Bultynck). - Olivieri \& Serpagli, p. 62, pl. 1, fig. 10a, b.

2004a Latericriodus bilatericrescens gracilis Bultynck. Slavík, pl. 1, fig. 9.

2004b Latericriodus bilatericrescens gracilis Bultynck. Slavík, p. 467, figs 11.19-11.21.

Type level. - The holotype is from sample 20-1 of the Tjafane section, about $25 \mathrm{~km}$ east of Akka, western Dra Valley. The sample is from the base of the Oui-n-Mesdoûr Formation, which is of lower Emsian age (Becker 2004a, Jansen et al. 2007). The precise level seems to predate the latus Zone (locally with Lat. beckmanni beckmanni) of the main part of the Akhal Tergoua Member further to the west (e.g., of Bou Tserfine).

Discussion. - The specimen of Fig. $17 \mathrm{H}$ is very similar to the holoype. The subspecies can be distinguished from typical Lat. bilatericrescens by the concavo-convex outline of the spindle, which is slightly biconvex in the latter (especially in its holotype). Moreover, in bilatericrescens bilatericrescens the middle row denticles are smaller and in adult specimens they are connected with the transversal lateral row denticles, which is not the case in bilatericrescens gracilis. In the latter the middle and lateral row denticles are rounded and do not fuse laterally. Another characteristic of bilatericrescens gracilis is the irregular pattern of the denticles on the outer lateral process. The inner process meets the spindle extension one denticle before the outer process. In Lat. claudiae the posterior outer lateral process is clearly shorter than in L. bilatericrescens gracilis.
Stratigraphic range. - Lower Emsian (of proposed future definition), bilatericrescens gracilis to middle latus Zone (middle Anetoceras Limestone of the Tafilalt, Sample BTN 31-1). Its oldest record in the Barrandian is from the higher Dvorce-Prokop Limestone, from just below the monograptid marker interval ("atopus Event”, Slavík 2004b: section Na Branzovech, Sample 26B).

Icriodus praerectirostratus Bultynck sp. nov. Figure 25Q-X

Derivation of name. - Because the morphology and stratigraphic range suggest that it is the direct ancestor of $I$. rectirostratus Bultynck, 1970.

Types. - Holotype b6682, illustrated in Fig. 25Q, R; five paratypes b6683-6687 (Fig. 25S-X).

Type level and locality. - Lower part of Lower Member of Timrhanrhart Formation, upper Emsian, El Anhsour, Sample 2, fusiformis Zone.

Diagnosis. - P1 element characterized by a strong spur, pointed in an oblique angle to the anterior, showing obvious nodes or a marked costa, and a posterior extension of the middle denticle row with transversally developed ridges.

Description. - The spindle is slightly concavo-convex, slightly curved, and the anterior end is pointed. There are six to seven transversal denticle rows on the spindle. The denticles of the middle row are much smaller than the rounded or oval denticles of the lateral rows and they are mostly connected by a longitudinal thin ridge. The basal cavity is well expanded. On the outer side the border of the cavity is rounded and on the inner side there is a prominent triangular spur with nodes or a costa. In smaller specimens (Fig. 25V) all these characteristics are only weakly developed. In specimen b6684 (Fig. 25T) the posterior denticles show an especially distinctive transverse widening.

Discussion. - In I. rectirostratus there is only a thin ridge on the surface of the spur (Bultynck 1970, pl. 30, figs 7, 8) and the denticles of the posterior extension of the middle row are not transversally developed.

Stratigraphic range. - At present only known from the basal upper Emsian fusiformis Zone.

Icriodus ovalis Bultynck sp. nov.

Figure $25 \mathrm{E}-\mathrm{G}$

Derivation of name. - From the Latin ovalis, according to the oval outline of the spindle. 
Types. - Holotype b6672, upper view illustrated in Fig. 25F; Paratypes b6671 (lateral view in Fig. 25E) and b6673 (upper view in Fig. 25G).

Type level and locality. - Uppermost part of Mdâouer-el-Kbîr Formation, upper Emsian, El Anhsour, Sample I, fusiformis Zone.

Diagnosis. - P1 element characterized by a slender, biconvex spindle with a large number of slightly oval lateral row denticles and smaller middle row denticles. In the posterior part of the spindle the denticles are smaller and the last middle row denticle is clearly inclined.

Description. - In the holotype the number of lateral row denticles is ten. In upper view they are slightly oval, larger than the middle row denticles and not fused. There are two to three middle row denticles behind the spindle and they are strongly inclined. In lateral view the upper margin of the spindle is slightly convex. The outline of the border of the basal cavity is not much laterally expanded in the posterior part of the P1 element.

Discussion. - In the ca contemporaneous Icriodus homorectus the margins of the spindle are straight and there are more denticles in the posterior extension of the middle denticle row.

Stratigraphic range. - Icriodus ovalis sp. nov. occurs together with $L$. inversus, I. fusiformis, I. corniger ancestralis, and Caud. culicellus culicellus in the basal part of the upper Emsian.

Order Agoniatitida Ruzhentsev, 1957

Family Mimoceratidae Steinmann in

Steinmann \& Döderlein, 1890

\section{Genus Klugites Becker gen. nov.}

Derivation of name. - In honor of Christian Klug (Zürich), for his significant contributions to the knowledge of early ammonoids from the Tafilalt.

Type species. - Lenzites gesinae Klug, 2001 (currently monospecific).

Diagnosis. - Mature shell strongly compressed (ww/dm ca 0.25 , ww/wh $<0.5$ ), subevolute (uw/dm ca 0.35 ), with small imprint zone, and very high whorl expansion rate (WER 2.7 to 3.0). Growth lirae rectiradiate, concavo-convex, with deep and wide flank sinus and narrow, moderately high ventrolateral salient bordered by a fine spiral ridge. Sutures with small ventral lobe, asymmetrically rounded, narrow ventral saddle, deeply rounded lateral lobe occupying the flanks, and small internal lobe. Suture formula: ELI.

Discussion. - Klug (2001) assigned his new species to Lenzites Becker \& House, 1994 and agreed that the genus occupies an intermediate position between the Teicherticeratidae and Mimoceratidae. The Tafilalt species, however, differs significantly from Lenzites, whose type species, L. lenzi (House \& Pedder, 1963), is from the lower Emsian of Yukon, NW Canada. These differences justify the introduction of a new genus. The true Lenzites has much lower WER rates, rursiradiate (not rectiradiate), slightly biconvex (not fully concavo-convex) growth lines, with a shallow (not deep) flank sinus, and impressions on the venter as in Chebbites. There is no evidence for an imprint zone or dorsal (internal) lobe. Klugites gen. nov. combines the distinctive and advanced Gyroceratites-type ornament with the introduction of an imprint zone. Therefore, it is regarded as a descendent of Gyroceratites, not as an ancestor. Lenzites remains at its transitional position between the Teicherticeratidae and Gyroceratites.

Mimagoniatites and other genera of the Mimagoniatitidae differ by their well-rounded, much less compressed shells.

Stratigraphic and geographic range. - Restricted to the gesinae Zone of the Tafilalt (higher Anetoceras Limestone) and eastern Dra Valley (lower member of the Mdâouer-el-Kbîr Formation, De Baets et al. 2010).

\section{Acknowledgements}

The authors are indebted to A. El Hassani (Rabat) for his co-operation and general support. S. Hartenfels and S. Stichling assisted RTB \& ZSA in the field, the late H. Hollard and O.H. Walliser took part in the initial field work of PB. A. Fekkak (El Jadida) and L. Baidder (Casablanca) enabled the sampling at Hassi Nebech, Jebel el-Mrier, Jebel Kfiroun, and El Khraouia during joint field work. Conodont samples were processed und picked in Münster by E. Kuropka, T. Fischer, S. Stichling, K. Schwermann, and S. Helling. T. Fährenkemper edited photos and produced section logs and correlation charts. The German Research Foundation provided financial support in the frame of the joint project $\mathrm{BE}$ 1367/11-1 - AB 278/2-1. P. Carls (Wolfenbüttel/Braunschweig), C. Martínez-Pérez (Valencia), and L. Slavík (Praha) provided very helpful comments on the manuscript. P. Bultynck thanks A. Vandersypen and W. Miseur for their assistance with illustrations and photo plates. This paper is a contribution to IGCP 596.

\section{References}

Aboussalam, Z.S. \& BeCKER, R.T. 2013. Lower Emsian stratigraphy at Jebel Ihrs (western Tafilalt Platform), 135-141. In BECKER, R.T., El HASSANI, A. \& TAhIRI, A. (eds) International 
Field Symposium "The Devonian and Lower Carboniferous of northern Gondwana”, Field Guidebook, Document de l'Institut Scientifique, Rabat 27.

AKSENova, L.M. 1987. Novye konodonty iz zlihovskih otlozhenii Gornogo Altaya, 90-95. In BulynNiKovA, S.P. \& KLimova, I.G. (eds) Novye vidy drevnikh rasteniy i bespozvonochnykh iz. fanerozoya Sibiri. Siberian Scientific-Research Institute of Geology, Geophysics and Mineral Resources, Novosibirsk.

AlBerTI, G.K.B. 1980. Neue Daten zur Grenze Unter-/MittelDevon, vornehmlich aufgrund der Tentaculiten und Trilobiten im Tafilalt (SE-Marokko). Neues Jahrbuch für Geologie und Paläontologie, Monatshefte 1980(10), 581-594.

AlberTI, G.K.B. 1981. Daten zur stratigraphischen Verbreitung der Nowakiidae (Dacryoconarida) im Devon von NW-Afrika (Marokko, Algerien). Senckenbergiana lethaea 62(2-6), 205-216.

AlberTI, G.K.B. 1982. Paläontologische Daten zum Grenzbereich Pragium/Zlichovium (Unter-Devon) auf Grund der Tentaculiten (Dacryoconarida). Newsletters on Stratigraphy 11(1), 22-31.

AlberTi, G.K.B. 1993. Dacryoconaride und homoctenide Tentaculiten des Unter- und Mitteldevons. Courier Forschungsinstitut Senckenberg 158, 1-229.

AlberTi, G.K.B. 1998. Planktonische Tentakuliten des Devon. III. Dacryoconarida Fisher 1962 aus dem Unter-Devon und oberen Mitteldevon. Palaeontographica, Abteilung A 250(1-3), 1-46.

AL-Rawi, D. 1977. Biostratigraphische Gliederung der Tentaculiten-Schichten des Frankenwaldes mit Conodonten und Tentaculiten (Unter- und Mittel-Devon, Bayern, Deutschland). Senckenbergiana lethaea 58(1-3), 25-79.

APEKINA, L.S. 1989. Novyi konodont iz nizhnego devona Zeravshanskogo khrebta. Paleontogicheskiy zhurnal 1989(1), 119-120.

Apekina, L.S. \& Mashrova, T.V. 1978. Conodonts, pls 73-78. In SoKolov, S.B. \& GARKovets, V.G. (eds) Type sections of the Lower and Middle Devonian boundary beds in Middle Asia, Field Session of the International Subcommission on Devonian Stratigraphy, A Guide to Field Excursions. Academy of Sciences of the USSR, Siberian Branch, Institute of Geology and Geophysics, Novosibirsk.

BAI, S., NING, Z. \& YIN, S. 1982. The Devonian conodonts of Guangxi, their sequence and systematic descriptions, 39-66. In BAI, S., JIN, S. \& Ning, Z. (eds) The Devonian biostratigraphy of Guangxi and adjacent areas. Peking University Press, Beijing.

BAI, Z. \& BAI, S. 1988. Conodont biostratigraphy of the Devonian Zdimir from Bahe, Guangxi, China. Canadian Society of Petroleum Geologists, Memoir 14(3), 529-534.

BARANOv, V.V. 1991. Konodonty i zonal'naia stratigrafya nizhnego devona Vostochnoi Yakutii, regional'naya geologiya $i$ poleznye iskopaemya Yakutii, 24-36. Izdatel'stvo Yakutskogo gosudarstvennogo universiteta, Yakutsk.

BARANOv, V.V. 2012. Lower Devonian Conodont Zonation in Arctic Regions of Eurasia. Stratigraphy and Geological Correlations 20(2), 179-198. DOI 10.1134/S0869593812010029

Baranov, V.V. \& AL' KHOVIK, T.S. 2003. Conodonts of Gagievodus Baranov \& Alkhovik, gen. nov., and Vjaloviodus Gagiev genera in Lower Devonian of the Northeast Asia. Otechestvennaia geologia 2003(6), 92-96. [in Russian]

Baranov, V.V., Slavík, L. \& Blodgett, R.B. 2014. Early Devonian polygnathids of Northeast Asia and correlation of Pragian
Emsian strata of the marginal seas of Angarida. Bulletin of Geosciences 89(3), 645-678. DOI 10.3140/bull.geosci.1483

Barca, S., Gnoli, M., Olivieri, R. \& Serpagli, E. 1986. New stratigraphic data and evidence of Lower and Upper Devonian based on conodonts in Sarabus area. Rivista Italiana di Paleontologia e Stratigrafia 92(3), 299-320.

BARDASHEv, I.A. 1986. Emsian conodonts of the Polygnathus genus from central Tadzhikistan. Paleontologicheskii zhurnal 1986(2), 61-66. [in Russian]

Bardashev, I.A. \& Weddige, K. 2003. The invalid genus name Costapolygnathus Bardashev, Weddige \& Ziegler 2002 and the new conodont genus Eucostapolygnathus. Senckenbergiana lethaea $85(1-2), 1-2$.

Bardashev, I., Weddige, K. \& Ziegler, W. 2002. The phylomorphogenesis of some Early Devonian platform conodonts. Senckenbergiana lethaea 82(2), 375-451.

BARDASHEV, I. \& ZIEGLER, W. 1992. Conodont biostratigraphy of Lower Devonian deposits of the Shishkat section (Southern Tien-Shan, Middle Asia). Courier Forschungsinstitut Senckenberg 154, 1-29.

BARRANDE, J. 1865. Systême silurien du centre de la Bohême. Ière Partie: Recherches Paléontologiques. Vol. II. Céphalopodes. 107 pls. Kayserliche und Königliche Hof- und Staatsdruckerei Wien, Praha \& Paris.

BARRANDE, J. 1867. Systême silurien du centre de la Bohême. Ière Partie: Recherches Paléontologiques. Vol. III. Pteropodes. 179 pp. Kayserliche und Königliche Hof- und Staatsdruckerei Wien, Praha \& Paris.

Becker, G., Lazreq, N. \& Weddige, K. 2003. Ostracods of Thuringian provenance in the Lower Devonian of Eurasia and North Africa with special reference to the Emsian of Morocco. Courier Forschungsinstitut Senckenberg 242, 39-49.

BeCKER, R.T. 1997. Minutes of the SDS Business Meeting, $21^{\text {th }}$ July, Rochester. SDS Newsletter 14, 2-5.

BeCKer, R.T. 2003. Minutes of the SDS Business Meeting, Toulouse, June 2002. SDS Newsletter 19, 5-10.

BECKER, R.T. 2007. Emsian substages and the Daleje Event - a consideration of conodont, dacryoconarid, ammonoid and sealevel data. SDS Newsletter 22, 29-32.

BeCKER, R.T. 2009. Minutes of the SDS Business Meeting, Kitab State Geological Reserve, Uzbekistan, $2^{\text {nd }}$ September 2008. SDS Newsletter 24, 12-15.

BeCKER, R.T. 2012. The uncounted species of Polygnathus - plea for clear tracks through a taxonomic jungle. SDS Newsletter $27,42-48$.

BeCKer, R.T. \& Aboussalam, Z.S. 2011. Emsian chronostratigraphy - preliminary new data and a review of the Tafilalt (SE Morocco). SDS Newsletter 26, 33-43.

Becker, R.T. \& Aboussalam, Z.S. 2013. The global Chotec Event at Jebel Amelane (western Tafilalt Platform) - preliminary data, 129-134. In BeCKER, R.T., El HASSANI, A. \& TAHIRI, A. (eds) International Field Symposium "The Devonian and Lower Carboniferous of northern Gondwana", Field Guidebook, Document de l'Institut Scientifique, Rabat 27.

Becker, R.T., Aboussalam, Z.S., Baider, L., El Hassani, A. \& Stichling, S. 2013b. The Lower and Middle Devonian at El Khraouia (southern Tafilalt), 31-40. In BECKER, R.T., EL HASSANI, A. \& TAHIRI, A. (eds) International Field Symposium "The Devonian and Lower Carboniferous of northern Gondwana”, Field Guidebook, Document de l'Institut Scientifique, Rabat 27. 
Becker, R.T., Aboussalam, Z.S., Bockwinkel, J., Ebbighausen, V., El Hassani, A. \& NüBEL, H. 2004b. Upper Emsian stratigraphy at Rich Tamelougou near Torkoz (SW Dra Valley, Morocco). Documents de l'Institut Scientifique 19, 85-89.

BeCKer, R.T., Aboussalam, Z.S. \& BRETt, C.E. 2008. High-resolution biostratigraphy of Emsian mixed siliciclastic-carbonate successions of the western Dra Valley (Anti-Atlas, SW-Morocco), 14-18. In Kim, A.I., Salimova, F.A. \& MeshchanKINA, N.A. (eds) International Conference "Global alignments of Lower Devonian carbonate and clastic sequences", IGCP 499 Project/SDS joint field meeting, Kitab State Geological Reserve, Uzbekistan, August 25 - September 3, 2008, Contributions. SealMag Press, Tashkent.

Becker, R.T., Bockwinkel, J., Ebbighausen, V., Aboussalam, Z.S., El Hassani, A. \& NüBel, H. 2004c. Lower and Middle Devonian stratigraphy and faunas at Bou Tserfine near Assa (Dra Valley, SW Morocco). Documents de l'Institut Scientifique 19, 90-100.

Becker, R.T., De Baets, K. \& Nikolaeva, S. 2010. New ammonoid records from the lower Emsian of the Kitab Reserve (Uzbekistan - preliminary results). SDS Newsletter 25, 20-28.

BeCKer, R.T., El HASSANI, A. \& TAHIRI, A. (eds) 2013a. International Field Symposium "The Devonian and Lower Carboniferous of northern Gondwana", Field Guidebook. Document de l'Institut Scientifique, Rabat 27, 1-150.

Becker, R.T., Gradstein, F.M. \& Hammer, O. 2012. The Devonian Period, 559-601. In Gradstein, F.M., OGG, J.G., SchmitZ, M.D. \& OGG, G. (eds) The Geological Time Scale 2012, vol. 2. Elsevier, Amsterdam.

Becker, R.T., Hartenfels, S., Aboussalam, Z.S., Tragelehn, H., BRice, D. \& El Hassani, A. 2013c. The Devonian-Carboniferous boundary at Lalla Mimouna (northern Maider) - a progress report, 109-120. In BeCKer, R.T., El HASSANI, A. \& TAHIRI, A. (eds) International Field Symposium "The Devonian and Lower Carboniferous of northern Gondwana", Field Guidebook, Document de l'Institut Scientifique, Rabat 27.

BECKER, R.T. \& House, M.R. 1994. International Devonian goniatite zonation, Emsian to Givetian, with new records from Morocco. Courier Forschungsinstitut Senckenberg 169, 79-135.

BeCKer, R.T. \& House, M.R. 2000. Emsian and Eifelian ammonoid succession at Bou Tchrafine (Tafilalt platform, Anti-Atlas, Morocco). Notes et Mémoires du Service Géologique 399, 21-36.

Becker, R.T., House, M.R., Bockwinkel, J., Ebbighausen, V. \& Aboussalam, Z.S. 2002. Famennian ammonoid zones of the eastern Anti-Atlas (southern Morocco). Münstersche Forschungen zur Geologie und Paläontologie 93, 159-205.

Becker, R.T., Jansen, U., Plodowski, G., Schindler, E., Aboussalam, Z.S. \& Weddige, K. 2004a. Devonian litho- and biostratigraphy of the Dra Valley - an overview. Documents de l'Institut Scientifique 19, 3-18.

Belka, Z., Kaufmann, B. \& Bultynck, P. 1997. Conodont-based quantitative biostratigraphy for the Eifelian of the eastern Anti-Atlas, Morocco. GSA Bulletin 109(6), 643-651. DOI 10.1130/0016-7606(1997)109<0643:CBQBFT>2.3.CO;2

Belka, Z., Klug, C., Kaufmann, B., Korn, D., Döring, S., Feist, R. \& WeNDT, J. 1999. Devonian conodont and ammonoid succession of the eastern Tafilalt (Ouidane Chebbi section), Anti-Atlas, Morocco. Acta Geologica Polonica 49, 1-23.
Benfrika, E.M. \& Bultynck, P. 2003. Lower to Middle Devonian conodonts from the Oued Cherrat area and its southern extension (North-Western Meseta, Morocco). Courier Forschungsinstitut Senckenberg 242, 209-215.

Benfrika, E.M., Bultynck, P. \& El Hassani, A. 2007. Upper Silurian to Middle Devonian conodont faunas from the Rabat-Tiflet area (northwestern Moroccan Meseta). Geological Quarterly 51(4), 393-406.

Bensaid, M. 1974. Etude sur des Goniatites à la limite du Dévonien Moyen et Supérieur, du Sud Marocain. Notes de Service Carte géologique du Maroc 36(264), 81-140.

Beyrich, E. 1837. Beiträge zur Kenntnis der Versteinerungen des Rheinischen Übergangsgebirges. 44 pp. Berlin.

Bischoff, G. \& Sannemann, D. 1958. Unterdevonische Conodonten aus dem Frankenwald. Notizblätter des hessischen Landesamtes für Bodenforschung 86, 87-110.

Bockwinkel, J., Becker, R.T. \& EBbighausen, V. 2002. Morphometry and taxonomy of Lower Famennian Sporadoceratidae (Goniatitida) from Southern Morocco. Abhandlungen der Geologischen Bundesanstalt 57, 279-297.

Bockwinkel, J., Becker, R.T. \& Ebbighausen, V. 2013. Late Givetian ammonoids from Hassi Nebech (Tafilalt Basin, Anti-Atlas, southern Morocco). Fossil Record 16(1), 5-65. DOI 10.5194/fr-16-5-2013

BoERSMA, K.T. 1974. Description of certain Lower Devonian platform conodonts of the Spanish Central Pyrenees. Leidse Geologische Mededelingen 49(2), 285-301.

BogosLovsKIY, B.I. 1972. Novye rannedevonskie golovonogie Novoy Zemli. Paleontologicheskii zhurnal 1972(4), 44-51.

BoncheVA, I. 1991. Conodont biostratigraphy of the Lower Devonian in Southwest Bulgaria. Geologica Balcanica 21(4), $55-72$.

Boncheva, I., Sachanski, V., Lakova, I. \& Yaneva, M. 2007. Facies transition and biostratigraphic correlation of the Upper Silurian and Lower Devonian in West Bulgaria. Geological Quarterly 51(4), 407-418.

BoučEK, B. 1964. The Tentaculites of Bohemia. Their morphology, taxonomy, ecology, phyloneny and biostratigraphy. 215 pp. Publishing House of Czechoslovak Academy of Sciences, Praha.

BouČEK, B. 1966. Eine neue bisher jüngste Graptolithen Fauna aus dem böhmischen Devon. Neues Jahrbuch für Geologie und Paläontologie, Monatshefte 3, 161-168.

BoučEK, B. \& PRANTL, F. 1959. Význam tentaculitů pro stratigrafii středočeského devonu. Časopis Národního musea 128(1), 5-7.

Branson, E.B. \& Mehl, M.G. 1933. A study of Hinde's types of conodonts preserved in the British Museum. University of Missouri Studies 8(2), 133-156.

Branson, E.B. \& Mehl, M.G. 1938. The conodont genus Icriodus and its stratigraphic distribution. Journal of Paleontology 12(2), 156-166.

Brett, C.E., Zambito, J.J. IV, Schindler, E. \& Becker, R.T. 2012. Diagenetically-enhanced trilobite obrution deposits in concretionary limestones: The paradox of "rhythmic event beds". Palaeogeography, Palaeoclimatology, Palaeoecology 367/368, 30-43. DOI 10.1016/j.palaeo.2011.12.004

BUCHROITHNER, M.F. 1978. Zur Conodontenstratigraphie vorwiegend klastischer Folgen im Devon der Ost- und Zentralpyrenäen. Mitteilungen der österreichischen geologischen Gesellschaft 69, 247-266. 
BuChroithner, M.F. 1979. Biostratigraphische und fazielle Untersuchungen im Palaeozoikum von Mittelkärnten. Carinthia II 169(89), 71-95.

Bultynck, P. 1970. Révision stratigraphique et paléontologique de la coupe type du Couvinien. Mémoires de l'Institut Géologique de l'Université de Louvain 26, 1-152.

Bultynck, P. 1971. Le Silurien superieur et le Dévonien inferieur de la Sierra de Guadarrama (Espagne Centrale). Deuxième partie: assemblages de Conodontes à Spathognathodus. Bulletin du Institut royal des Sciences naturelles Belgique, Sciences de la Terre 47(3), 1-43.

Bultynck, P. 1976. Le Silurien superieur et le Dévonien inferieur de la Sierra de Guadarrama (Espagne Centrale). Troisième partie: Elements icriodiformes, pelekysgnathiformes et polygnathiformes. Bulletin du Institut royal des Sciences naturelles Belgique, Sciences de la Terre 49(5), 1-74.

Bultynck, P. 1979 (with contributions by Hollard, H., García-Alcalde, J.L., House, M.R. \& Soto, F.) Excursion in the Devonian of the Sierra de Guadarrama between Cercadillo and La Riba de Santiuste, 32-34. In GarCíA-AlCALDE, J.R. et al. (eds) Guidebook of the Field Trip, Meeting of the International Subcommission on Devonian Stratigraphy, Spain 1979. Servicio de Publicaciones de la Universidad, Oviedo.

Bultynck, P. 1985. Lower Devonian (Emsian) - Middle Devonian (Eifelian and lowermost Givetian) conodont successions from the Ma'der and the Tafilalt, southern Morocco. Courier Forschungsinstitut Senckenberg 75, 261-286.

Bultynck, P. 1989. Conodonts from the La Grange Limestone (Emsian), Armorican Massif, North-Western France. Courier Forschungsinstitut Senckenberg 117, 173-203.

Bultynck, P. 1991. Section Jbel Ou Driss (Mapsheet Tarhbalt, NH-30-XIII-4), 17-23. In Walliser, O.H. (ed.) Morocco 1991, Field Meeting of the Subcommisuion on Devonian Stratigraphy, International Union of Gelological Sciences, Nov. 28 -Dec. 5, 1991, Guide-Book. Göttingen.

BultYNCK, P. 1998. Regional and local facies influences on conodont distribution in Emsian to earliest Eifelian successions of southern Morocco, 22-23. In B AGNOLI, G. (ed.) Seventh International Conodont Symposium held in Europe, Abstract. Tipografia Compositori, Bologna.

BultYnCK, P. 2003. Devonian Icriodontidae: biostratigraphy, classification and remarks on paleoecology and dispersal. Revista Española de Micropaleontología 35(3), 295-314.

Bultynck, P. \& Godefroid, J. 1974. Excursion G, 1-42. In Guidebook International Symposium on Belgian micropaleontological limits from Emsian to Viséan, Namur 1974. Geological Survey of Belgium, Bruxelles.

Bultynck, P. \& Hollard, H. 1980. Distribution comparée de Conodontes et Goniatites dévoniens des plaines du Dra, du Ma'der et du Tafilalt. Aardkundige Mededelingen 1, 1-73.

Bultynck, P. \& Hollard, H. 1982. An Emsian to lower Frasnian conodont and goniatite succession from southern Morocco, 46-50. In Biostratigraphy of Lower and Middle Devonian boundary deposits. Proceedings of Field Symposium of the International Subcommission on Devonian Stratigraphy, Samarkand, UDSSR, 1978. Leningrad. [in Russian with English summary]

Bultynck, P., Hollard, H., House, M.R., García-Alcalde, J. \& Soто, F. 1979. Excursion in the Devonian of the Sierra de Guadarrama between Cercadillo and La Riba de Santiuste, 32-34. In García-AlCALDE, J.L. et al. (eds) Meeting of the In- ternational Subcommission on Devonian Stratigraphy, Spain 1979, Guidebook of the Field Trip. Servicio de Publicaciones de la Universidad, Oviedo.

Bultynck, P., Lardeux, H. \& Walliser, O.H. 2000. On the correlation of middle-Emsian. SDS Newsletter 17, 10-11.

Bultynck, P. \& Morzadec, P. 1979. Conodontes de la coupe de Reun ar C'Hrank en Lanvéoc (Rade de Brest), Emsien du Massif Armoricain (France), corrélations biostratigraphiques. Geobios 12, 675-685. DOI 10.1016/S0016-6995(79)80096-0

Bultynck, P. \& Walliser, O.H. 2000a. Emsian to Middle Frasnian sections in the Northern Tafilalt. Notes et Mémoires du Service géologique 399, 11-20.

Bultynck, P. \& Walliser, O.H. 2000b. Devonian Boundaries in the Moroccan Anti-Atlas. Courier Forschungsinstitut Senckenberg 225, 211-226.

CARLS, P. 1999. El Devónico de Celtiberia y sus fósiles, 101-164. In GÁmez-Vintaned, J.A. \& LiÑan, E. Memorias de las VI Jornadas Aragonesas de Paleontología "25 años de Paleontología", Homenaje al Prof. Leandro Sequeiros. Institut Fernando el Católigo, Zaragoza.

Carls, P. \& GandL, J. 1969. Stratigraphie und Conodonten des Unter-Devons der Östlichen Iberischen Ketten (NE-Spanien). Neues Jahrbuch für Geologie und Paläontologie, Abhandlungen 132, 155-218.

Carls, P., Gandl, J., Groos-Uffenorde, H., JahnKe, H. \& Walliser, O.H. 1972. Neue Daten zur Grenze Unter-/MittelDevon. Newsletters on Stratigraphy 2(3), 115-147.

CARLS, P. \& Gong, D. 1992. Devonian and Early Carboniferous conodonts from Shidian (Western Yunnan, China). Courier Forschungsinstitut Senckenberg 154, 179-221.

Carls, P., Slavík, L. \& Valenzuela-Ríos, J.I. 2008. Comments on the GSSP for the basal Emsian stage boundary: the need for its redefinition. Bulletin of Geosciences 83(4), 383-390. DOI 10.3140/bull.geosci.2008.04.383

Carls, P., Slavík, L. \& Valenzuela-Ríos, J.I. 2009. Request and comments concerning the GSSP for the basal Emsian stage boundary. SDS Newsletter 24, 20-27.

Carls, P. \& Valenzuela-Ríos, J.I. 2002. Early Emsian conodonts and associated shelly faunas of the Mariposas Fm (Iberian Chains, Aragón, Spain). Cuadernos del Museo Geominero $1,315-333$.

Carls, P. \& Valenzuela-Ríos, J.I. 2007. From the Emsian GSSP to the early late Emsian - correlations with historical boundaries. SDS Newsletter 22, 24-28.

Chlupéč, I. 1995. Evaluation of some Devonian standard boundaries. Nova Acta Leopoldina, Neue Folge 71(291), 41-52.

Chlupáč, I. \& Kukal, Z. 1986. Reflection of possible global Devonian events in the Barrandian area, C.S.S.R. Lecture Notes on Earth Sciences 8, 171-179. DOI 10.1007/bfb0010202

Chlupáč, I. \& Kukal, Z. 1988. Possible global events and the stratigraphy of the Palaeozoic of the Barrandian (CambrianMiddle Devonian, Czechoslovakia). Sborník geologických věd, Geologie 43, 83-146.

Chlupéč, I. \& Lukeš, P. 1999. Pragian/Zlíchovian and Zlíchovian/Dalejan boundary sections in the Lower Devonian of the Barrandian area, Czech Republic. Newsletters on Stratigraphy 37(1-2), 75-100.

Chlupáč, I., Lukeš, P., PARis, F. \& SchÖnlaub, H.-P. 1985. The Lochkovian-Pragian Boundary in the Lower Devonian of the Barrandian Area (Czechoslovakia). Jahrbuch der Geologischen Bundesanstalt 128, 9-41. 
Colquhoun, G.P. 1995. Early Devonian conodont faunas from the Capertee High, NE Lachlan Fold Belt, southeastern Australia. Courier Forschungsinstitut Senckenberg 182,347-369.

Corradini, C. \& Corriga, M.G. 2012. A Přídolí-Lochkovian conodont zonation in Sardinia and the Carnic Alps: implications for a global zonation scheme. Bulletin of Geosciences 87(4), 635-650. DOI 10.3140/bull.geosci.1304

De Baets, K., Klug, C. \& Monnet, C. 2013. Intraspecific variability through ontogeny in early ammonoids. Palaeobiology 39(1), 75-94. DOI 10.1666/0094-8373-39.1.75

De Baets, K., Klug, C. \& Plusquellec, Y. 2010. Zlíchovian faunas with early ammonoids from Morocco and their use for the correlation of the eastern Anti-Atlas and the western Dra Valley. Bulletin of Geosciences 85(2), 317-352. DOI 10.3140/bull.geosci.1172

Destombes, J. \& Hollard, H. (eds) 1986. Carte géologique du Maroc: Tafilalt - Taouz, Echelle 1/200000. Notes et Mémoires du Service Géologique du Maroc 244, 1 map.

Dojen, C., Aboussalam, Z.S. \& Becker, R.T. 2010. Palaeoecological and biogeographical interpretation of Devonian ostracodes (Emsian to basal Givetian) of the Western Dra Valley, Morocco (sections Bou Tserfine, Rich Tamelougou and Hassi Mouf). SDS Newsletter 25, 37-40.

Dojen, C., Aboussalam, Z.S. \& Becker, R.T. 2011. Lowermost Emsian to lower Givetian ostracods from the Western Dra Valley (Morocco): First palaeoecological and event-stratigraphical data. Joannea Geologie und Paläontologie 11, 53-54.

Dongal, G.M.S. 1995. Early Devonian (Pragian and early Emsian) fauna from the eastern Tamworth Terrane, New South Wales. Memoirs of the Association of Australasian Palaeontologists 18, 131-142.

DöRING, S. 2002. Sedimentological evolution of the late Emsian to early Givetian carbonate ramp in the Mader (eastern Anti-Atlas, SE Morocco). 80 pp. Dissertation, EberhardKarls-Universität Tübingen.

http://tobias-lib.ub.uni-tuebingen.de/volltexte/2002/560/

DRYGANT, D. \& SZANIAWSKI, H. 2012. Lochkovian conodonts from Podolia, Ukraine, and their stratigraphic significance. Acta Palaeontologica Polonica 74(4), 833-861. DOI 10.4202/app.2012.0124

Ebbighausen, V., Becker, R.T. \& Bockwinkel, J. 2011. Emsian and Eifelian ammonoids from Oufrane, eastern Dra Valley (Anti-Atlas, Morocco) - taxonomy, stratigraphy and correlation. Neues Jahrbuch für Geologie und Paläontologie, Abhandlungen 259, 313-379.

DOI 10.1127/0077-7749/2011/0121

Ebbighausen, V., Bockwinkel, J., Becker, R.T., Aboussalam, Z.S., Bultynck, P., El Hassani, A. \& Nübel, H. 2004. Late Emsian and Eifelian stratigraphy at Oufrane (Tata region, eastern Dra Valley, Morocco). Documents de l'Institut Scientifique 19, 44-52.

EichenberG, W. 1931. Die Schichtenfolge des HerzbergAndreasberger Sattelzuges. Neues Jahrbuch für Mineralogie, Geologie und Paläontologie, Beilage-Band B 65, 141-196.

EikHVALD, L.P. 2008. Devonian conodonts of the Amur Region. Russian Journal of Pacific Geology 2(3), 244-254. DOI $10.1134 / \mathrm{S} 1819714008030056$

ERbEN, H.K. 1960. Primitive Ammonoidea aus dem Unterdevon Frankreichs und Deutschlands. Neues Jahrbuch für Geologie und Paläontologie, Abhandlungen 110(1), 1-128.
FÅnRaeus, L.E. 1974. Taxonomy and evolution of Ozarkodina steinhornensis and Ozarkodina optima (Conodontophorida). Geologica et Palaeontologica 8, 29-37.

Feist, R., Schönlaub, H.-P. \& Bultynck, P. 1985. Faciès et biostratigraphie (conodontes) du passage Dévonien Inférieur-Moyen dans la Montagne Noire (France). Hercynica 1(2), 81-97.

Ferrová, L., Frýda, J. \& Lukeš, P. 2012. High-resolution tentaculite biostratigraphy and facies developments across the Early Devonian Daleje Event in the Barrandian (Bohemia): implications for global Emsian stratigraphy. Bulletin of Geosciences 87(3), 587-624. DOI 10.3140/bull.geosci.1336

FRÖHLICH, S. 2004. Evolution of a Devonian carbonate shelf at the northern margin of Gondwana (Jebel Rheris, eastern Anti-Atlas, Morocco). 71 pp. Dissertation, Eberhard-Karls-Universität Tübingen.

FurEy-GreiG, T. 1995. The "Nemingha" and "Loomberah" limestones (Early Devonian; Emsian) of the Nemingha-Nundle area, northern New South Wales: conodont data and inferred environments. Courier Forschungsinstitut Senckenberg 182, 217-233.

Gaetani, M., Mawson, R., Sciunnach, D. \& Talent, J.A. 2008. The Devonian of Western Karakorum (Pakistan). Acta Geologica Polonica 58(3), 261-285.

GAGIEv, M.H. 2000. Sedimentary evolution and sea-level fluctuations in the Devonian of North-East Asia. Courier Forschungsinstitut Senckenberg 199, 75-82.

GAGIEv, M.H. \& Rodygin, S.A. 1988. Zonal'noe raschlenenie i korrelatsia otlozhenii srednego devona Salaira i SeveroVostoka SSSR po konodontam, 28-44. In Podobina, V.M. (ed.) Materialy po paleontologii i stratigrafii zapodnoi Sibiri. Izdatel'stvo Tomskogo universiteta, Tomsk.

GarCíA-AlCALDE, J. 1997. North Gondwanan Emsian events. Episodes 20(4), 241-246.

García-Alcalde, J. 1998. Devonian events in northern Spain. Newsletters on Stratigraphy 36(2-3), 157-175.

GARCíA-LóPEZ, S. 1987. Los conodontos y su aplicación al studio de las divisiones cronostrátigraficas mayors del Devonico asturleonés (España). Boletín Geólogico y Minero, publicaciones especiales 47(3-5), 1-112.

García-López, S. \& Alonso-Menendez, C. 1994. Conodontos del Grupo la Vid, limites Praguiense/Emsiense y Emsiense inferior/Emsiense superior, Zona Cantábrica (NO de España). Revista Española de Micropaleontología 26(2), 81-97.

García-López, S., JAhNKe, H. \& SANZ-LóPeZ, J. 2002. Uppermost Pridoli to Upper Emsian stratigraphy of the Alto Carrión Unit, Palentine Domain (Northwest Spain). Cuadernos del Museo Geominero 1, 229-257.

García-López, S., Julivert, M., Soldevila, J., TruyolsMassoni, M. \& Zamarreño, I. 1990. Biostratigrafía y Facies de la sucesíón carbonatada del Silúrico Superior y Devónico Inferior de Santa Creu d'Olorda (Cadenas Costeras Catalanas, NE de España). Acta Geológica Hispánica 25(1-2), 141-168.

Garcia-López, S. \& Sanz-López, J. 2002. Devonian to Lower Carboniferous conodont stratigraphy of the Bernesga Valley section (Cantabrian Zone, NW Spain). Cuadernos del Museo Geominero 1, 163-205.

Gélard, J.-P., Bossière, G., Legrand, P., Semenoff-TianChansky, P. \& Weyant, M. 1978. Ler Dévonien d'Ihamziene dans la Dorsale Kabyle (massif de Chellata, Grande Kabylie): sa stratigraphie et son complexe volcano-sédimentaire 
spilitique. Bulletin de la Société géologique de France 20(3), 277-289. DOI 10.2113/gssgfbull.S7-XX.3.277

Gouwy, S. \& Bultynck, P. 2002. Graphic correlation of Middle Devonian sections in the Ardenne region (Belgium) and the Mader-Tafilalt region (Morocco): development of a Middle Devonian composite standard. Aardkundige Mededelingen 12, 105-108.

Gradstein, F.M., OGG, J.G. \& SMith, A.G. (eds) 2004. A Geological Time Scale 2004. 589 pp. Cambridge University Press, Cambridge. DOI 10.4095/215638

Hinde, G.J. 1879. On conodonts from the Chazy and Cincinnati group of the Cambrian-Silurian, and from the Hamilton and Genesee Shale divisions of the Devonian, in Canada and the United States. Quarterly Journal of the Geological Society of London 35(3), 351-369.

DOI 10.1144/GSL.JGS.1879.035.01-04.23

Hollard, H. 1960. Vorläufiger Bericht über die Silur-DevonStratigraphie des vorsaharischen Marokko, 437-453. In SvoвoDA, J. (ed.) Prager Arbeitstagung über die Stratigraphie des Silurs und des Devons (1958). Ústřední ústav geologický, Praha.

Hollard, H. 1963a. Un tableau stratigraphique du Dévonien du Sud de l'Anti-Atlas. Notes du Service Géologique du Maroc 23, 105-109.

Hollard, H. 1963b. Présence d'Anetoceras advolvens Erben (Ammonoidée primitive) dans le Dévonien inférieur du Maroc présaharien. Notes du Service Géologique du Maroc 23(172), 131-139.

Hollard, H. 1967. Le Dévonien du Maroc et du Sahara nord-occidental, 203-244. In OswaLd, D.H. (ed.) International Symposium on the Devonian System, Calgary, 1967 I. Alberta Society of Petroleum Geologists, Calgary.

Hollard, H. 1974. Recherches sur la stratigraphie des formations du Dévonien moyen, de l'Emsien supérieur au Frasnien, dans le Sud du Tafilalt et dans le Ma'der (Anti-Atlas oriental). Notes du Service géologique du Maroc 36(264), 7-78.

Hollard, H. 1978. Corrélations entre niveaux à brachiopods et à goniatites au voisinage de la limite Dévonien inférieur Dévonien moyen dans les plaines du Dra (Maroc présaharien). Newsletters on Stratigraphy 7(1), 8-25.

Hollard, H. 1981a. Principaux caractères des formations dévoniennes de l'Anti-Atlas. Notes du Service Géologique du Maroc 42(308), 15-22.

Hollard, H. 1981b. Tableux de corrélations du Silurien et du Dévonien de l'Anti-Atlas. Notes du Service Géologique du Maroc 42, 1-308.

Hollard, H. \& Jaquemont, P. 1956. Le Gothlandien, le Dévonien et le Carbonifère des régions du Dra et du Zemoul. Notes du Service Géologique du Maroc 15, 7-33.

House, M.R. \& Pedder, A. E. 1963. Devonian goniatites and stratigraphical correlations in Western Canada. Palaeontology 6(3), 491-539.

IzoKH, N.G. 1990. Ikriodusy telengitskogo nadgorizonta Salaira (konodonty; devon, ems), 107-111. In Yolkin, E.A. \& KANYgin, A.V. (eds) Novoe v paleontologii i biostratigrafii paleozoia aziatskoi chasti SSSR. Nauka, Novosobirsk.

IzoKH, N.G. 1998. Konodonty i zonal'noe raschlenenie emskikh otlozheniy Salaira. 24 pp. Izdatel'stvo SO RAN, NITS OIGGM, Novosibirsk.

Izokн, N.G. 2005. Emsian conodonts from Tashtyp Formation (Tuva, south of West Siberia), 68-69. In Yolkin, E.A., IzoKH, N.G., OBut, O.T. \& KipRIYANova, T.P. (eds) International
Conference "Devonian Terrestrial and Marine Environments: From Continent to Shelf” (IGCP 499 Project / SDS joint field meeting), Contributions. Publishing House of SB RAS "Geo" Branch, Novosibirsk.

Izokh, N.G., ValenZuela-Ríos, J.I. \& Slavík, L. 2011b. Conodont report of the Zinzilban Gorge Emsian GSSP and up. SDS Newsletter 26, 57-58.

Izokh, N.G., Yolkin, E.A., Weddige, K., ERina, M.V. \& Valenzuela-Ríos, J.I. 2011a. Late Pragian and early Emsian conodont polygnathid species from the Kitab State Geological Reserve sequences (Zeravshan-Gissar mountainous area, Uzbekistan). News on Paleontology and Stratigraphy, Supplement to Geologiya i Geofizika 52(15), 49-63.

JANSEN, U. 2012. On the traditional Siegenian-lower Emsian successions in the Rhenish Slate Mountains, in special consideration of the basal Emsian boundary and its supraregional correlation. SDS Newsletter 27, 21-27.

Jansen, U., Becker, G., Plodowski, G., Schindler, E., Vogel, O. \& Weddige, K. 2004a. The Emsian to Eifelian near Foum Zguid (NE Dra Valley, Morocco). Documents de l'Institut Scientifique 19, 19-28.

Jansen, U., Becker, G., Plodowski, G., Schindler, E., Vogel, O. \& Weddige, K. 2004b. Pragian and Emsian near Aouinet Torkoz (SW Dra Valley, Morocco). Documents de l'Institut Scientifique 19, 75-84.

Jansen, U., Lazreq, N., Plodowski, G., Schemm-Gregory, M., SchindLeR, E. \& Weddige, K. 2007. Neritic-pelagic correlation in the Lower and basal Middle Devonian of the Dra Valley (Southern Anti-Atlas, Moroccan Pre-Sahara), 9-37. In BECKER, R.T. \& KIRCHGASSER, W.T. (eds) Devonian Events and Correlations. Geological Society of London, Special Publications 278.

JANSEN, U. \& SchindLER, E. 1997. Subdivision of the Emsian stage - German Subcommission on Devonian Stratigraphy. SDS Newsletter 14, 8-9.

JentZsCH, I. 1962. Conodonten aus dem Tentaculitenknollenkalk (Unterdevon) in Thüringen. Geologie 11(8), 961-985.

Jin, S., Shen, A., Chen, Z., Lu, J., Wie, M., Wang, Y. \& Xie, F. 2005. Mixed Biostratigraphy of Devonian in Wenshan, Yunnan. 195 pp. Petroleum Industry Press.

Johnson, D.B. \& Klapper, G. 1981. New Early Devonian conodont species of central Nevada. Journal of Paleontology 55(6), 1237-1250.

Johnson, J.G., Klapper, G., Murphy, M.A. \& Trojan, W.R. 1985. Devonian Series Boundaries in Central Nevada and neighbouring regions, Western North America. Courier Forschungsinstitut Senckenberg 75, 177-196.

Johnson, J.G., Klapper, G. \& Trojan, W.R. 1980. Brachiopod and conodont successions in the Devonian of the northern Antelope Range, central Nevada. Geologica et Palaeontologica $14,77-116$.

KalvodA, J. 1995. Conodont Fauna from the Pragian/Emsian boundary in the Mramorka and Stydlé vody Quarry (Barrandian, Czech Republic). Věstník Českého geologického ústavu 70(2), 33-44.

Kaufmann, B. 1998. Facies, stratigraphy and diagenesis of Middle Devonian reef- and mud-mounds in the Mader (eastern Anti-Atlas, Morocco). Acta Geologica Polonica 48(1), 43-106.

Kaufmann, B. 2006. Calibrating the Devonian Time Scale: A synthesis of U-Pb ID-TIMS ages and conodont stratigraphy. Earth Science Reviews 76, 175-190.

DOI 10.1016/j.earscirev.2006.01.001 
KAYSER, E. 1884. Die Orthocerasschiefer zwischen Balduinstein und Laurenburg an der Lahn. Jahrbuch der Preussischen Geologischen Landesanstalt 1883, 1-56.

Kim, A.I., Erina, M.V., Kim, I.A., Salimova, F.A., MeshchanKINA, N.A. \& RAKhmonov, U.D. 2012. The Pragian-Emsian event and subdivision of the Emsian in the Zinzilban and Khodzha-Kurgan sections. SDS Newsletter 27, 38-41.

Kim, A.I., Erina, M.V., Yolkin, E.A. \& Sennikov, N.V. 1988. Subdivision and correlation of the Devonian of South Fergana (Turkestan-Alai Mountain area, U.S.S.R.). Canadian Society of Petroleum Geologists, Memoir 14(3), 703-714.

KLAPPER, G. 1969. Lower Devonian conodont sequence, Royal Creek, Yukon Territory, and Devon Island, Canada. Journal of Paleontology 43(1), 1-27.

KLAPPER, G. 1971. Sequence within the conodont genus Polygnathus in the New York lower Middle Devonian. Geologica et Palaeontologica 5, 59-79.

KLAPPER, G. 1977. Lower and Middle Devonian conodont sequence in central Nevada, with contributions by D.B. Johnson, 33-54. In Murphy, M.A., Berry, W.B.N. \& SAndBerg, C.A. (eds) Western North America: Devonian, University of California, Riverside Campus Museum Contributions 4.

KLAPPER, G. \& Johnson, D.B. 1975. Sequence in conodont genus Polygnathus in Lower Devonian at Lone Mountain, Nevada. Geologica et Palaeontologica 9, 65-83.

KLAPPER, G. \& Johnson, J.G. 1980. Endemism and dispersal of Devonian conodonts. Journal of Paleontology 54, 400-455.

KLAPPER, G. \& PhILIP, G. 1971. Devonian conodont apparatuses and their vicarious skeletal elements. Lethaia 4, 429-452. DOI 10.1111/j.1502-3931.1971.tb01865.x

KlAPPER, G. \& VodrÁžKOVÁ, S. 2013. Ontogenetic and intraspecific variation in the late Emsian-Eifelian (Devonian) conodonts Polygnathus serotinus and P. bultyncki in the Prague Basin (Czech Republic) and Nevada (western U.S.). Acta Geologica Polonica 63(2), 153-174. DOI 10.2478/agp-2013-0006

KLAPPER, G. \& ZiEGLER, W. 1967. Evolutionary development of the Icriodus latericrescens Group (Conodonta) in the Devonian of Europe and North America. Palaeontographica, Abteilung A 127(1-3), 68-83.

Klapper, G., Ziegler, W. \& MashKova, T.V. 1978. Conodonts and correlation of Lower-Middle Devonian boundary beds in the Barrandian area of Czechoslowakia. Geologica et Palaeontologica 12, 103-116.

Klishevich, V.L., Biske, Y.S., SAvitsky, Y.V. \& Eykhgorn, T.F. 1985. Biostratigraphy of the Lower and Middle Devonian Beds of the Shakhimardan River Basin, Southern Fergana. Courier Forschungsinstitut Senckenberg 75, 83-92.

KLUG, C. 2001. Early Emsian ammonoids from the eastern Anti-Atlas (Morocco) and their succession. Paläontologische Zeitschrift 74(4), 479-515. DOI 10.1007/BF02988158

KLUG, C. 2002. Quantitative stratigraphy and taxonomy of late Emsian and Eifelian ammonoids of the eastern Anti-Atlas (Morocco). Courier Forschungsinstitut Senckenberg 238, $1-109$.

Klug, C., Korn, D., Naglik, C., Frey, L. \& De Baets, K. 2013. The Lochkovian to Eifelian succession of the Amessoui Syncline (southern Tafilalt), 51-59. In BECKER, R.T., EL HaSsani, A. \& TAHIRI, A. (eds) International Field Symposium "The Devonian and Lower Carboniferous of northern Gond- wana", Field Guidebook, Document de l'Institut Scientifique, Rabat 27.

Klug, C., Korn, D. \& Reisdorf, A. 2000. Ammonoid and conodont stratigraphy of the late Emsian to early Eifelian (Devonian) at the Jebel Ouaoufilal (near Taouz, Tafilalt, Morocco). Travaux de l'Institut Scientifique, Rabat, Série Géologie \& Géographie Physique 20, 45-56.

Klug, C., Kröger, B., Rücklin, M., Korn, D., Schemm-Gregory, M., De BaEts, K. \& Mapes, R.H. 2008. Ecological change during the early Emsian (Devonian) in the Tafilalt (Morocco), the origin of the Ammonoidea, and the first African pyrgocystid edrioasteroids, machaerids, and phyllocarids. Palaeontographica, Abteilung A 283, 83-176.

KRÖGER, B. 2008. Nautiloids before and during the origin of ammonoids in a Silurian-Devonian section in the Tafilalt, Anti-Atlas, Morocco. Special Papers in Palaeontology 79, $1-110$.

KuANG, G. \& Zhou, H. 1992. The Standard Devonian Section and Sedimentary Types in Guangxi, China. International Symposium on the Devonian System, its Economy Oil and Mineral Resources, September 9-12, 1992, Guilin, Field Trip No. 2, 22 pp.

Kullmann, J. 1960. Die Ammonoidea des Devon im Kantabrischen Gebirge (Nordspsanien). Akademie der Wissenschaften und der Literatur, Abhandlungen der mathematischnaturwissenschaftlichen Klasse 1960(7), 457-559.

KuZ'MIN, A.M. 1967. The first finding of conodonts in the Lower Devonian deposits of the Central Taimyr. Ucheniye zapiski NIIGA 1967(20), 20-27.

Lane, H.R., MüLler, K.J. \& Ziegler, W. 1979. Devonian and Carboniferous conodonts from Perak, Malaysia. Geologica et Palaeontologica 13, 213-226.

LANE, H.R. \& ORMiston, A.E. 1979. Siluro-Devonian biostratigraphy of the Salmontrout area, east-central Alaska. Geologica et Palaeontologica 13, 39-96.

Lardeux, H. \& Weyant, M. 1993. Conodontes et tentaculites (dacryoconarides) du Calcaire de Valet en Chaudefonds (Dévonien Inférieur, Massif Armoricain, Anjou). Revue de Micropaléontologie 36(1), 19-28.

LazreQ, N. 1990. Devonian conodonts from Central Morocco. Courier Forschungsinstitut Senckenberg 118, 65-79.

Long, J.A. \& Burrett, C.F. 1989. Early Devonian conodonts from the Kuan Tung Formation, Thailand. Systematics and biogeographic considerations. Records of the Australian $\mathrm{Mu}$ seum 41, 121-133. DOI 10.3853/j.0067-1975.41.1989.140

Lu, J.-F. 2013. Late Emsian (Lower Devonian) conodonts from Bahe section, Tiandeng County, Guangxi. Acta Palaeontologica Sinica 52(3), 309-330. [in Chinese with English abstract]

Lubeseder, S., Rath, J., Rücklin, M. \& Messbacher, R. 2010. Controls on Devonian hemi-pelagic limestone deposition analyzed on cephalopod ridge to slope sections, Eastern Anti-Atlas, Morocco. Facies 56, 295-315.

DOI 10.1007/s10347-009-0205-5

Lubeseder, S., Redfern, J. \& Boutib, L. 2009. Mixed siliciclastic-carbonate shelf sedimentation - Lower Devonian sequences of the SW Anti-Atlas, Morocco. Sedimentary Geology 215, 13-32. DOI 10.1016/j.sedgeo.2008.12.005

LuPPOLD, F.W. 1984. Ein kondensiertes Unterdevon-Profil bei Wieda, SW-Harz. Neues Jahrbuch für Geologie und Paläontologie, Monatshefte 1984(4), 223-238. 
LuPPOLD, F.W. 1987. Stratigraphie und Fazies im Steinbruch am Großen Mittelberg (SW-Harz; Devon). Neues Jahrbuch für Geologie und Paläontologie, Abhandlungen 175(3), 295-315.

Mamedov, A.B. \& Rzhonsnitskaya, M.A. 1985. Devonian of the South Transcaucasus, zonal divisions boundaries of series and stages, correlation. Courier Forschungsinstitut Senckenberg $75,135-156$.

Martínez-Pérez, C. 2010. Icriodus riosi, nueva especie de conodonto en el Devónico inferior del Pirineo Central Español. Revista Espanola de Paleontologia 25(2), 139-147.

Martínez-Pérez, C. \& Valenzuela-Ríos, J.I. 2012. Polygnathids (Conodonta) around the lower/upper Emsian boundary from the La Guardia d'Àres section (Lower Devonian, Spanish Central Pyrenees). Bolletino della Società Paleontologica Italiana 51(3), 193-202.

Martínez-Pérez, C. \& Valenzuela-Ríos, J.I. 2014. New Lower Devonian polygnathids (Conodonta) from the Spanish Central Pyrenees, with comments on the early radiation of the group. Journal of Iberian Geology 40(1), 141-155. DOI 10.5209/rev_JIGE.2014.v40.n1.44095

Martínez-Pérez, C., Valenzuela-Ríos, J.I. \& Botella, H. 2010. Polygnathus rosae n. sp. (Conodonta) and its biostratigraphical correlation potential (lower Emsian, Lower Devonian) in the Spanish Central Pyrenees. Rivista Italiana di Paleontologia e Stratigrafia 116(3), 273-281.

Martínez-Pérez, C., Valenzuela-Ríos, J.I., Navas-Parejo, P., Liao, J.-C. \& Botella, H. 2011. Emsian (Lower Devonian) Polygnathids (Conodont) succession in the Spanish Central Pyrenees. Journal of Iberian Geology 37(1), 45-64.

Mashrova, T.V. 1972. Ozarkodina steinhornensis (Ziegler) Apparatus, its conodonts and biozone. Geologica et Palaeontologica SB 1, 81-90.

Mashrova, T.V. 1979. Conodont zones of the Lower Devonian in the U.S.S.R. Geologica et Palaeontologica 13, 97-102.

Mashrova, T.V. \& Apekina, L.S. 1980. Prazhskie polignatusy (konodonty) zony dehiscens Sredney Asii. Paleontologicheskii zhurnal 1980(3), 135-140.

MAssA, D. 1965. Observations sur les series siluro-dévoniennes des confins Algéro-Marocaines du sud (1954-1955). Notes et Mémoires, Compagnie Francaise des Pétroles 8, 1-187.

Mavrinskaya, T. \& Slavík, L. 2013. Correlation of Early Devonian (Lochkovian-early Pragian) conodont faunas of the South Urals (Russia). Bulletin of Geosciences 88(2), 283-296. DOI 10.3140/bull.geosci.1404

Mawson, R. 1987a. Early Devonian conodont faunas from Buchan and Bindi, Victoria, Australia. Palaeontology 30(2), 251-297.

Mawson, R. 1987b. Documentation of conodont assemblages across the Early Devonian-Middle Devonian Boundary, Broken River Formation, North Queensland, Australia. Courier Forschungsinstitut Senckenberg 92, 251-273.

Mawson, R. 1995. Early Devonian polygnathid conodont lineages with special reference to Australia. Courier Forschungsinstitut Senckenberg 182, 389-398.

Mawson, R., Jell, J.S. \& Talent, J.A. 1985. Stage boundaries within the Devonian: implications for application to Australian sequences. Courier Forschungsinstitut Senckenberg 75, $1-16$.

Mawson, R. \& Talent, J.A. 1989. Late Emsian-Givetian stratigraphy and conodont biofacies - carbonate slope and offshore shoal to sheltered lagoon and nearshore carbonate ramp - Bro- ken River, North Queensland, Australia. Courier Forschungsinstitut Senckenberg 117, 205-259.

Mawson, R. \& TALEnT, J.A. 1994. Age of an Early Devonian carbonate fan and isolated limestone clasts and megaclasts, East-Central Victoria. Proceedings of the Royal Society of Victoria 106, 31-70.

Mawson, R. \& Talent, J.A. 2003. Conodont faunas from sequences on or marginal to the Anakie Inlier (Central Queensland, Australia) in relation to Devonian transgressions. Bulletin of Geosciences 78(4), 335-358.

MüLlER, K.J. 1962. Zur systematischen Einteilung der Conodontophorida. Palaeontologische Zeitschrift 36, 109-117. DOI 10.1007/BF02989634

Murphy, M.A. 2002. Pragian and basal Emsian zonal classification based on conodonts in Nevada, western North America. Strata, Série 1 12, 98.

Murphy, M.A. \& Cebecioglu, M.K. 1984. The Icriodus steinachensis and I. claudiae lineages (Devonian conodonts). Journal of Paleontology 58(6), 1399-1411.

Murphy, M.A. \& MatTI, J.C. 1983. Lower Devonian conodonts (hesperius-kindlei Zones), central Nevada. University of California Publications in Geological Sciences 123, 1-87.

Murphy, M.A., Valenzuela-Ríos, J.I. \& Carls, P. 2004. On classification of Pridoli (Silurian)-Lochkovian (Devonian) Spathognathodontidae (conodonts). University of California, Riverside, Campus Museum Contribution 6, 1-25.

NASEHI, E. 1997. Early to Middle Devonian conodonts from Central Iran. Geosciences, Quarterly Journal 6, 78-87.

Olivieri, R. \& Serpagli, E. 1990. Latest Silurian - early Devonian conodonts from the Mason Porcus Section near Fluminimaggiore, Southwestern Sardinia. Bolletino della Società Paleontologica Italiana 29(1), 59-76.

OrR, W. 1971. Conodonts from Middle Devonian strata of the Michigan Basin. Indiana Geological Survey, Bulletin 45, $1-110$.

OuAnaimi, H. \& LAZREQ, N. 2008. The "Rich" group of the Drâa Basin (Lower Devonian, Anti-Atlas, Morocco): an integrated sedimentary and tectonic approach, 467-482. In ENNIH, N. \& LiÉGEOIS, J.-P. (eds) The Boundaries of the West African Craton. Geological Society of London, Special Publications 297.

PhILIP, G.M. 1965. Lower Devonian conodonts from the Tyers Area, Gippsland, Victoria. Proceedings of the Royal Society of Victoria 79(1), 95-115.

PHILIP, G.M. 1966. Lower Devonian conodonts from the Buchan Group, eastern Victoria. Micropaleontology 12(4), 441-460. DOI $10.2307 / 1484789$

PhILIP, G.M. \& JACKSON, J. 1967. Lower Devonian subspecies of the conodont Polygnathus linguiformis Hinde from southeastern Australia. Journal of Paleontology 41(5), 1262-1266.

Plodowski, G., Becker, G., Brocke, R., Jansen, U., LazreQ, N., Schindler, E., Schraut, G., Wallisser, O.H., Weddige, K. \& ZIEGLER, W. 2000. The section at Jebel Issimour (NW Maider, Early to Early Middle Devonian). First results with respect to lithology and biostratigraphy. Notes et Mémoires du Service géologique 399, 43-48.

Pyle, L.J., Orchard, M.J., Barnes, C. \& Landry, M.L. 2002. Conodont biostratigraphy of the Lower to Middle Devonian Deserters Formation (new), Road River Group, northeastern British Columbia. Canadian Journal of Earth Sciences 40, 99-113. DOI 10.1139/e02-095 
RaO, J. \& Yu, H. 1985. The Devonian system in South Xizang (Tibet). Contributions to the Geology of the Qinghai-Xizang (Tibet) Plateau 16, 51-73. [in Chinese]

Requadt, H. \& Weddige, K. 1978. Lithostratigraphie und Conodontenfaunen der Wissenbacher Fazies und ihrer Äquivalente in der südwestlichen Lahnmulde (Rheinisches Schiefergebirge). Mainzer geowissenschaftliche Mitteilungen 7, 183-237.

RichteR, R. 1854. Thüringische Tentakuliten. Zeitschrift der Deutschen geologischen Gesellschaft 6(2), 275-290.

RuAn, Y.-P. \& He, G.-X. 1974. Devonian ammonoids, 238-239. In Nanjing Institute of Geology and Palaeontology, AcaDEMIA SINICA (ed.) Handbook of the stratigraphy and paleontology in Southwest China. Science Press, Beijing.

Ruzhentsev, S.V. 2001. The Variscan belt of south Mongolia and Dzungaria, 61-94. In Dergunov, A.B. (ed.) Tectonics, magmatism, and metallogeny of Mongolia. Routledge, London.

Ruzhentsev, V.E. 1957. Filogeneticheskaya sistema paleozoyskikh ammonoidey. Byulleten' Moskovskogo obshchestva, Otdel geologicheskiy 31(2), 49-64.

Rytina, M., Becker, R.T., Aboussalam, Z.S., Hartenfels, S., Helling, S., Stichling, S. \& Ward, D. 2013. The allochthonous Silurian-Devonian in olisthostromes at "The Southern Variscan Front" (Tinerhir region, SE Morocco) preliminary data, 11-21. In BeCKER, R.T., El Hassani, A. \& TAHIRI, A. (eds) International Field Symposium "The Devonian and Lower Carboniferous of northern Gondwana", Field Guidebook, Document de l'Institut Scientifique 27.

Rzhonsnitskaya, M.A., Timofeeva, O.B. \& Gagiev, M.H. 1990. Konodonty srednego devona Salaira, 46-57. In KhalymBADZHA, V.G. (ed.) Konodonty eifel'skogo yarusa SSSR. Izdatel'stvo Kazanskogo universiteta, Kazan.

SANZ-LóPez, J. 2002. Devonian and Lower Carboniferous rocks from the Cadi nappe (eastern Pyrenees). Cuadernos del Museo Geominero 1, 419-438.

SAvage, N.M. 1977. Lower Devonian conodonts from the Gazelle Formation, Klamath Mountains, northern California. Journal of Paleontology 51(1), 57-62.

SAVAge, N.M., Blodgett, R.B. \& JAeger, H. 1985. Conodonts and associated graptolites from the late Early Devonian of east-central Alaska and western Yukon Territory. Canadian Journal of Earth Sciences 22(12), 1880-1883.

DOI 10.1139/e85-200

SAYDAm-Demiray, D.G. \& CAPKINOGLU, S. 2012. Conodont fauna and biostratigraphy of the Early-Middle Devonian units in Beykoz, Sile and Kurtdogmus areas, Istanbul, Turkey. Bulletin of the Mineral Research and Exploration, Foreign Edition $145,1-21$.

SchÖNLAUB, H.P. 1985. Devonian conodonts from section Oberbuchach II in the Carnic Alps (Austria). Courier Forschungsinstitut Senckenberg 75, 353-374.

Schulze, R. 1968. Die Conodonten aus dem Palaeozoikum der mittleren Karawanken (Seeberggebiet). Neues Jahrbuch für Geologie und Paläontologie, Abhandlungen 130, 133-245.

Senglaub, M. \& Ebert, J.R. 2002. The Carlisle Center Formation: A new look, 8-9. In SUNY College at Oneonta, Student Research Day, www.oneonta.com/Devonian/1-lower-devonian.

Slavík, L. 2001. Lower Devonian conodonts from the Karlík Valley and Na Branzovech sections in the Barrandian area, Czech Republic, and their significance for Pragian conodont zonation. Acta Geologica Polonica 51(3), 253-271.

SLAVík, L. 2004a. The Pragian-Emsian conodont successions of the Barrandian area: search of an alternative to the GSSP polygnathid-based correlation concept. Geobios 37, 454-470. DOI 10.1016/j.geobios.2003.05.002

SLAVÍK, L. 2004b. A new conodont zonation of the Pragian Stage (Lower Devonian) in the stratotype area (Barrandian, central Bohemia). Newsletters on Stratigraphy 40(1-2), 39-71. DOI 10.1127/0078-0421/2004/0040-0039

Slavík, L. \& HLADIL, J. 2004. Lochkovian/Pragian GSSP revisited: evidence about conodont taxa and their stratigraphic distribution. Newsletters on Stratigraphy 40(3), 137-153. DOI 10.1127/0078-0421/2004/0040-0137

Slavík, L., Valenzuela-Ríos, J.I., Hladil, J. \& Carls, P. 2007. Early Pragian conodont-based correlations between the Barrandian area and the Spanish Central Pyrenees. Geological Journal 42, 499-512. DOI 10.1002/gj.1087

Sloan, T.R., Talent, J.A., Mawson, R., Simpson, A.J., Brock, G.A., Engelbretsen, M.J., Jell, J.S., Aung, A.K., Pfaffenritter, C., Trotter, J. \& Withnall, I.W. 1995. Conodont data from Silurian-Middle Devonian carbonate fans, debris flows, allochthonous blocks and adjacent autochthonous platform margins: Broken River and Camel Creek areas, north Queensland, Australia. Courier Forschungsinstitut Senckenberg 182, 1-77.

Somma, R., Navas-Parejo, P., Martín-Algarra, A., Rodríguez-Cañero, R., Perrone, V. \& Martínez-Pérez, C. 2013. Paleozoic stratigraphy of the Longi-Taormina Unit (Peloritanian Mountains, southern Italy). Stratigraphy 10(3), 127-152.

SnigiReva, M.P. 1975. Novye konodonty iz srednedevonskikh otlozheniy Severnogo Urala. Paleontologicheskii zhurnal 1975(4), 24-31.

Snigireva, M.P. \& Nasedkina, V.A. 1995. Conodonts from Early and Middle Devonian type sections on the eastern slope of the Urals. Courier Forschungsinstitut Senckenberg 182, 447-450.

Sobolev, N.N., Karatajute-TalimaA, V.N. \& Valiukevicius, Y.Y. 1988. Conodonts and vertebrates from the Zlobin Horizon and the Favosites regularissimus Zone (Lower Devonian) of Taimyr, Siberia, USSR. Canadian Society of Petroleum Geologists, Memoir 14(3), 535-539.

Sorentino, L. 1989. Conodont assemblages spanning the Lochkovian-Pragian (Early Devonian) Boundary at Eurimbla, Central New South Wales. Courier Forschungsinstitut Senckenberg 117, 81-115.

Stauffer, C.R. 1940. Conodonts from the Devonian and associated clays of Minnesota. Journal of Paleontology 14, 417-435.

Steinmann, G. \& DöDerlein, L. 1890. Elemente der Paläontologie. 848 pp. Engelmann, Leipzig.

Stichling, S. 2013. Biostrom-Abfolgen am Nordrand des Maider (S-Marokko): Mikrofazies, Paläoökologie und Stratigraphie. 87 pp. Unpublished M.Sc. thesis, Westfälische WilhelmsUniversität Münster.

SutTnER, T.J. 2007. Conodont stratigraphy, facies-related distribution patterns and stable isotopes (carbon and oxygen) of the uppermost Silurian to Lower Devonian Seewarte Section (Carnic Alps, Carinthia, Austria). Abhandlungen der Geologischen Bundesanstalt 59, 1-111.

Talent, J.A., Gaetani, M., Mawson, R., Molloy, P.D., Conaghan, P.J., Lehnert, O. \& Trotter, J.A. 1999. Early Ordovician and Devonian conodonts from the western Karakorum and Hindu Kush, northernmost Pakistan. Rivista Italiana di Paleontologia e Stratigrafia 105(2), 201-230. 
Talent, J.A. \& Mawson, R. 1994. Conodonts in relation to age and environmental framework of the Burdekin Basin (MidDevonian), North-Eastern Australia. Courier Forschungsinstitut Senckenberg 168, 61-81.

Talent, J.A. \& Mawson, R. 1999. North-eastern Molong Arch and adjacent Hill End Trough (Eastern Australia): mid-Paleozoic conodont data and implications. Abhandlungen der Geologischen Bundesanstalt 54, 49-105.

Telford, P.G. 1975. Lower and Middle Devonian conodonts from the Broken River Embayment, North Queensland, Australia. Special Papers in Palaeontology 15, 1-96.

Truyols-Massoni, M. 1998. La Edad de las Capas con Mimosphinctes en el Devónico de la Cordillera Cantabrica (NW de España). Trabajos de Geologia 21, 377-384.

Uyeno, T.T. \& KLAPPER, G. 1980. Summary of conodont biostratigraphy of the Blue Fiord and Bird Fiord formations (Lower-Middle Devonian) at the type and adjacent areas, southwestern Ellesmere Island, Canadian Arctic Archipelago. Geological Survey of Canada, Papers 80(1c), 81-93.

VAlenzuela-Ríos, J.I. 1994. Conodontos del Lochkoviense y Praguiense (Devónico Inferior) del Pirineo Central español. Memorias del Museo Paleontológico de la Universidad de Zaragoza 5, 1-178.

Valenzuela-Ríos, J.I. 1997. Can Polygnathus pireneae be the index of a standard conodont Zone? Newsletters on Stratigraphy 35(3), 173-179.

VAlenZuela-Ríos, J.I. 2002. Lochkovian and Pragian Conodonts from Segre 1 (Central Spanish Pyrenees). Cuadernos del Museo Geominero 1, 403-417.

VAn Adrichem Boogaert, H.A. 1967. Devonian and Lower Carboniferous conodonts of the Cantabrian Mountains (Spain) and their stratigraphic application. Leidse Geologische Mededelingen 39, 129-192.

VodrážKovÁ, S., KLAPPER, G. \& Murphy, M.A. 2011. Early Middle Devonian conodont faunas (Eifelian, costatus-kockelianus zones) from the Roberts Mountains and adjacent areas in central Nevada. Bulletin of Geosciences 86(4), 737-764. DOI 10.3140/bull.geosci.1292

Walliser, O.H. 1972. Conodont apparatuses in the Silurian. Geologica et Palaeontologica SB1, 75-80.

Walliser, O.H. 1991. Section Jebel Mech Irdane (Mapsheet Erfoud, NH-30-XX-2), 25-47. In WALliser, O.H. (ed.) Morocco 1991, Field Meeting of the Subcommission on Devonian Stratigraphy, International Union of Gelological Sciences, Nov. 28 -Dec. 5, 1991, Guide-Book. Göttingen.

WALLISER, O.H. 1997. Comments on the revision of the Emsian stage. SDS Newsletter 14, 10-11.

WANG, C.-Y. \& ZIEGLER, W. 1983. Devonian conodont biostratigraphy of Guangxi, South China, and the correlation with Europe. Geologica et Palaeontologica 17, 75-107.

Webster, G., Becker, R.T. \& MAPles, C.G. 2005. Biostratigraphy, paleoecology, and taxonomy of Devonian (Emsian and Famennian) crinoids from southeastern Morocco. Journal of Paleontology 79(6), 1052-1071. DOI 10.1666/0022-3360(2005)079[1052:BPATOD]2.0.CO;2

WedDIGE, K. 1977. Die Conodonten der Eifel-Stufe im Typusgebiet und in benachbarten Faziesgebieten. Senckenbergiana lethaea 58(4-5), 271-419.

Weddige, K. 2003. Nomenclatorical note. Revista Española de Micropalentología 35(3), 383.

Weddige, K. \& ReQuadt, H. 1985. Conodonten des Ober-Emsium aus dem Gebiet der Unteren Lahn (Rheinisches Schiefergebirge). Senckenbergiana lethaea 66(3-5), 347-381.

Weddige, K. \& ZiEgler, W. 1977. Correlation of Lower/Middle Devonian Boundary Beds. Newsletters on Stratigraphy 6(2), 67-84.

WitteKindT, H. 1966. Zur Conodontenchronologie des Mitteldevons. Fortschritte in der Geologie von Rheinland und Westfalen 9, 621-646.

Xiong, J. 1980. Conodonts, 82-100, 150-154. In XiAn, S. et al. Nandan typical stratigraphy and palaeontology of Devonian, in South China. Guizhou Peoples Press, Guiyang. [in Chinese]

Yolkin, E.A., BaKharev, N.K., IzOKH, N.G., Gratsianova, R.T., Kipriyanova, T.P. \& OBut, O.T. 2005. Devonian sequences of Salair, Rudny \& Gorny Altai. International Conference "Devonian Terrestrial and Marine Environments: From Continent to Shelf" (IGCP 499 Project / SDS joint field meeting), Field Excursion Guidebook. 79 pp. Publishing House of SB RAS “Geo" Branch, Novosibirsk.

Yolkin, E.A. \& IzoKH, N.G. 1988. Zonalnye vidy konodontov v tipovykh vykhodakh telengitskogo nadgorizonta (devon; Salair), 3-17. In Yolkin, E.A. \& Kanygin, A. (eds) Fauna $i$ stratigrafiya paleozoya Srednei Sibiri $i$ Urala. Nauka, Novosibirsk.

Yolkin, E.A., Izokh, N.G., Weddige, K., Erina, V., ValenZUElA-Ríos, J.I. \& APEKINA, L.S. 2011. Eognathodid and polygnathid lineages from the Kitab State Geological Reserve sections (Zeravshan-Gissar mountainous area, Uzbekistan) as the bases for improvements of the Pragian-Emsian standard conodont zonation. News on Paleontology and Stratigraphy, Supplement to Geologiya i Geofizika 52(15), 37-47.

Yolkin, E.A., KIM, A.I. \& Talent, J.A. (eds) 2008. Devonian sequences of the Kitab Reserve area. Field Excursion Guidebook, International Conference "Global Alignments of Lower Devonian Carbonate and Clastic Sequences" (SDS/IGCP 499 Project joint field meeting), Kitab State Geological Reserve, Uzbekistan, August 25 - September 3, 2008.99 pp. Publishing House of SB RAS "Geo" Branch, Novosibirsk.

Yolkin, E.A., Kim, A.I., Weddige, K., Talent, J.A. \& House, M.R. 1998. Definition of the Pragian/Emsian Stage Boundary. Episodes 20, 235-240.

Yolkin, E.A., Weddige, K., Izokh, N.G. \& Erina, M.V. 1994. New Emsian conodont zonation (Lower Devonian). Courier Forschungsinstitut Senckenberg 168, 139-157.

ZIEGLER, W. 1956. Unterdevonische Conodonten, insbesondere aus dem Schönauer und dem Zorgensis-Kalk. Notizblätter des hessischen Landesamtes für Bodenforschung 84, 93-106.

ZIEGLER, W. 1971. Conodont stratigraphy of the European Devonian, 227-284. In Sweet, W.C. \& Bergström, S.M. (eds) Symposium on conodont biostratigraphy. Geological Society of America, Memoirs 127.

Ziegler, W. (ed.) 1975. Catalogue of conodonts. Vol. 2. 404 pp. Schweizerbart, Stuttgart.

ZiegleR, W. \& LindströM, M. 1971. Über Panderodus Ethington, 1959, und Neopanderodus n. g. (Conodonta) aus dem Devon. Neues Jahrbuch für Geologie und Paläontologie 1971(10), 628-640.

ZIEGLER, W. \& WANG, C.-Y. 1985. Sihongshan Section, a regional reference section for the Lower-Middle and MiddleUpper Devonian Boundaries in East Asia. Courier Forschungsinstitut Senckenberg 75, 17-38. 